Prepared in cooperation with the

Directorate of Public Works,

Environmental Management Division

Aberdeen Proving Ground, Maryland

\title{
Design and Performance of an Enhanced Bioremediation Pilot Test in a Tidal Wetland Seep, West Branch Canal Creek, Aberdeen Proving Ground, Maryand
}
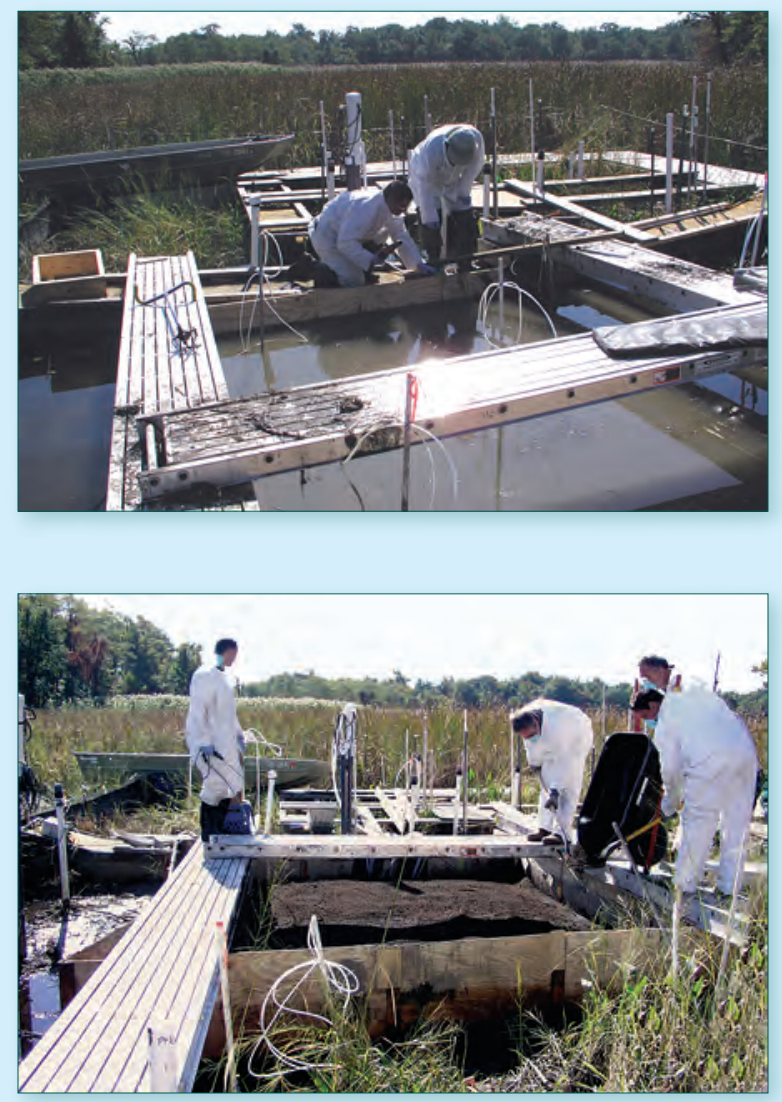

Scientific Investigations Report 2009-5112 
Cover. Photographs showing site preparation and sediment excavation for the installation of a reactive mat pilot test at seep area 3-4W, West Branch Canal Creek, Aberdeen Proving Ground, Maryland. (Photographs by U.S. Geological Survey.) 


\section{Design and Performance of an Enhanced Bioremediation Pilot Test in a Tidal Wetland Seep, West Branch Canal Creek, Aberdeen Proving Ground, Maryland}

By Emily H. Majcher ${ }^{2}$, Michelle M. Lorah', Daniel J. Phelan', and Angela L. McGinty ${ }^{3}$

${ }^{1}$ U.S. Geological Survey, Baltimore, Maryland.

${ }^{2}$ Geosyntec Consultants, Inc., formerly of the U.S. Geological Survey.

${ }^{3}$ EA Engineering, Science, and Technology, Inc., formerly of the U.S. Geological Survey.

Prepared in cooperation with the

Directorate of Public Works,

Environmental Management Division

Aberdeen Proving Ground, Maryland

Scientific Investigations Report 2009-5112 


\title{
U.S. Department of the Interior DIRK KEMPTHORNE, Secretary
}

\author{
U.S. Geological Survey \\ Mark D. Myers, Director
}

U.S. Geological Survey, Reston, Virginia: 2009

For more information on the USGS - the Federal source for science about the Earth, its natural and living resources, natural hazards, and the environment, visit http://www.usgs.gov or call 1-888-ASK-USGS

For an overview of USGS information products, including maps, imagery, and publications, visit http://www.usgs.gov/pubprod

To order this and other USGS information products, visit http://store.usgs.gov

Any use of trade, product, or firm names is for descriptive purposes only and does not imply endorsement by the U.S. Government.

Although this report is in the public domain, permission must be secured from the individual copyright owners to reproduce any copyrighted materials contained within this report.

Suggested citation:

Majcher, E.H., Lorah, M.M., Phelan, D.J., and McGinty, A.L., 2009, Design and performance of an enhanced bioremediation pilot test in a tidal wetland seep, West Branch Canal Creek, Aberdeen Proving Ground, Maryland: U.S. Geological Survey Scientific Investigations Report 2009-5112, 70 p. plus appendixes. 


\section{Contents}

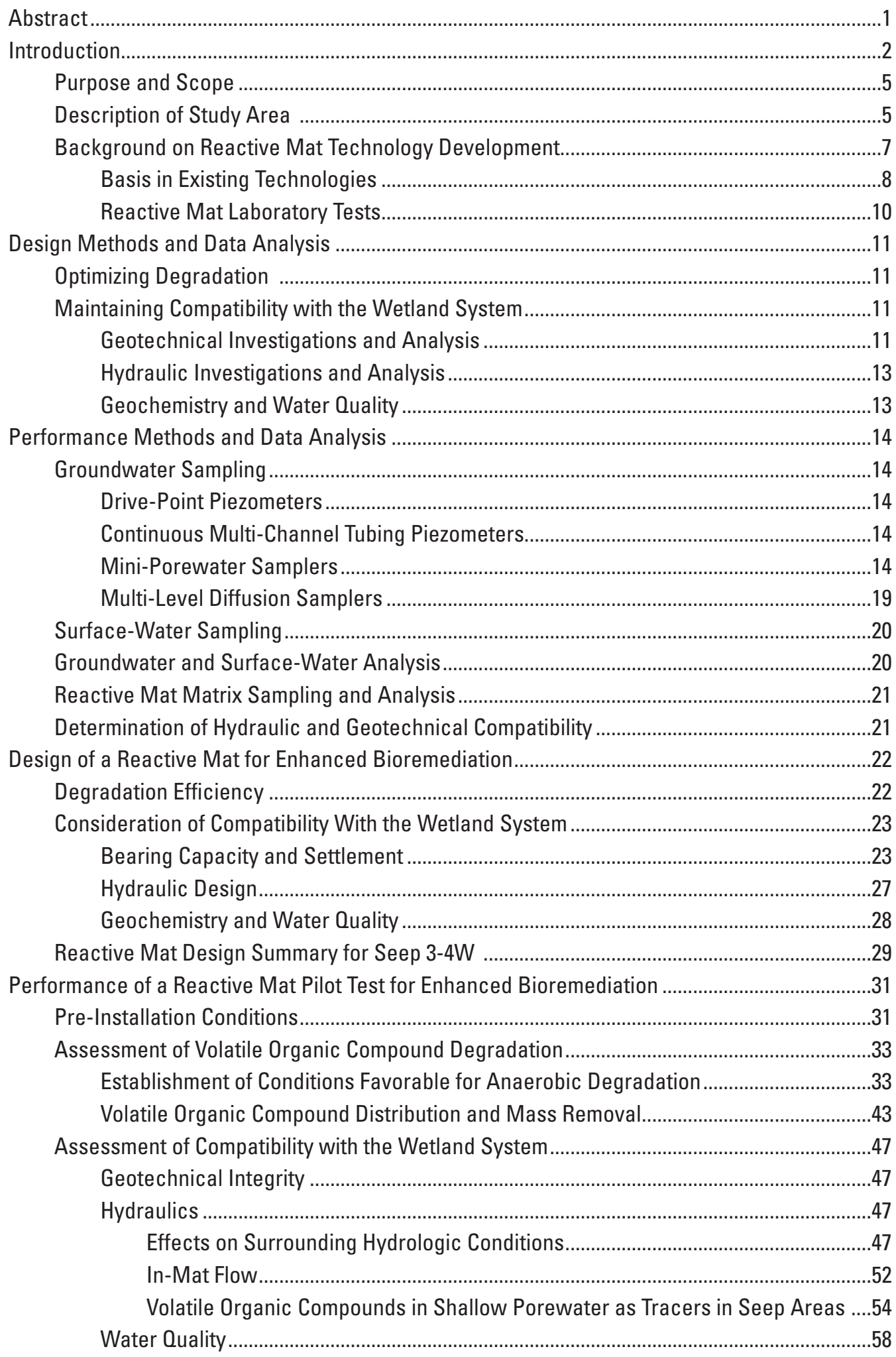




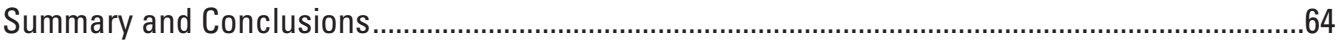

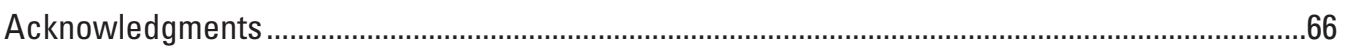

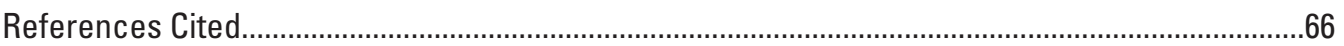

Appendix 1A. Field Measurements, and Concentrations of Reduction-0xidation (Redox)Sensitive Constituents and Nutrients from Groundwater Samples, Seep 3-4W Reactive Mat Pilot Test Area, West Branch Canal Creek, Aberdeen Proving Ground, Maryland, August 2004-January 2005. available online

Appendix 1B. Field Measurements, and Reduction-0xidation (Redox)-Sensitive Constituents from Groundwater Samples, Seep 3-4W Reactive Mat Pilot Test Area, West Branch Canal Creek, Aberdeen Proving Ground, Maryland, March-0ctober 2005. available online

Appendix 2A. Field Measurements and Concentrations of Inorganic Constituents from Groundwater and Surface-Water Samples, Seep 3-4W Reactive Mat Pilot Test Area, West Branch Canal Creek, Aberdeen Proving Ground, Maryland, August 2004-January 2005. available online

Appendix 2B. Field Measurements and Concentrations of Inorganic Constituents from Groundwater and Surface-Water Samples, Seep 3-4W Reactive Mat Pilot Test Area, West Branch Canal Creek, Aberdeen Proving Ground, Maryland, February-August 2005. available online

Appendix 3A. Organic Constituents from Groundwater and Surface-Water Samples from Seep 3-4W Reactive Mat Pilot Test Area, West Branch Canal Creek, Aberdeen Proving Ground, Maryland, August 2004-January 2005 available online

Appendix 3B. Organic Constituents from Groundwater and Surface-Water Samples from Seep 3-4W Reactive Mat Pilot Test Area, West Branch Canal Creek, Aberdeen Proving Ground, Maryland, February-September 2005. available online

Appendix 4. Quality Assurance for Volatile Organic Compound, Methane, and Inorganic Analyses available online

Appendix 5A. Sequential Extraction Procedure Analysis of Wetland Sediment Sample GT34W-5, Seep 3-4W Reactive Mat Pilot Test Area, West Branch Canal Creek, Aberdeen Proving Ground, Maryland available online

Appendix 5B. Sequential Extraction Procedure Analysis of Wetland Sediment Sample GT34W-14, Seep 3-4W Reactive Mat Pilot Test Area, West Branch Canal Creek, Aberdeen Proving Ground, Maryland available online

Appendix 5C. Sequential Extraction Procedure Analysis of Organic Mix with BionSoil Compost, Seep 3-4W Reactive Mat Pilot Test Area, West Branch Canal Creek, Aberdeen Proving Ground, Maryland available online

Appendix 5D. Sequential Extraction Procedure Analysis of Organic Mix with Chesapeake Blue Compost, Seep 3-4W Reactive Mat Pilot Test Area, West Branch Canal Creek, Aberdeen Proving Ground, Maryland. available online

Appendix 5E. Sequential Extraction Procedure Analysis of Organic Mix with Leafgro Compost, Seep 3-4W Reactive Mat Pilot Test Area, West Branch Canal Creek, Aberdeen Proving Ground, Maryland available online

Appendix 6A. Hydrograph Showing Water Levels in Upland Monitoring Well CC27A, August 2004-05, West Branch Canal Creek, Aberdeen Proving Ground, Maryland. available online

Appendix 6B. Hydrograph Showing Water Levels in Piezometer Pair PTZ4, Seep 3-4W Reactive Mat Pilot Test Area, September 2004-05, West Branch Canal Creek, Aberdeen Proving Ground, Maryland available online 


\section{Figures}

1a-1b. Maps showing-

1a. Location of the West Branch Canal Creek study area, Aberdeen

Proving Ground, Maryland

1b. Location of pilot-test seep and natural attenuation study areas, West Branch Canal Creek, Aberdeen Proving Ground,Maryland.

2a-2b. Diagrams showing-

2a. Anaerobic degradation pathways for tetrachloroethene, trichloroethene, hexachlororethane, and 1,1,2,2-tetrachloroethane ...................................................

2b. Anaerobic and aerobic degradation pathways for carbon tetrachloride..................7

3. Graphs and maps showing lines of section N-N' and M-M' showing slope of wetland surface along two transects within seep area 3-4W, West Branch Canal Creek, Aberdeen Proving Ground, Maryland, (A) location of lines of section, $(B)$ transect N-N', and $(C)$ transect $\mathrm{M}-\mathrm{M}^{\prime}$

4. Diagram showing conceptual model of a reactive mat .....................................................10

5a-5b. Maps showing-

5a. Seep 3-4W piezometer network, location of reactive mat, and lines of section $D^{-} D^{\prime}, E-E^{\prime}, Y-Y^{\prime}$, and Z-Z' at pilot-test study area, West Branch Canal Creek, Aberdeen Proving Ground, Maryland

5b. Location of multi-level diffusion samplers (PTBs) and mini-porewater samplers (PTNs) at the pilot-test study area, West Branch Canal Creek, Aberdeen Proving Ground, Maryland

6. Photographs showing multi-level diffusion samplers (PTBs) in the reactive mat $(A)$ construction, $(B)$ assembly, and $(C)$ deployment at seep 3-4W, West Branch Canal Creek, Aberdeen Proving Ground, Maryland.

7. Graphs showing concentrations of major chlorinated volatile organic compounds predicted by BioChlor in a simulated reactive mat (A) chlorinated ethenes and ethanes [tetrachloroethene (PCE), trichloroethene (TCE), 1,1,2,2-tetrachloroethane (TeCA), 1,2-dichloroethene (DCE), and vinyl chloride (VC)], and (B) chlorinated methanes [carbon tetrachloride (CT), chloroform (CF), and methylene chloride (MeCl)].

8. Diagram showing reactive mat schematic for seep 3-4W, West Branch Canal Creek, Aberdeen Proving Ground, Maryland $(A)$ cross-sectional view, and (B) plan view.

9. Photographs showing installation of a reactive mat pilot test at seep 3-4W,

West Branch Canal Creek, Aberdeen Proving Ground, Maryland,

$(A)$ site preparation, $(B)$ sediment excavation, $(C)$ reactive material placement, and (D) bioaugmentation with WBC-2

10. Maps showing distribution of selected volatile organic compounds in shallow porewater, seep location 3-4W, April (DS163-DS176) and December (DS317-DS332) 2003 in relation to the reactive mat pilot test, West Branch Canal Creek, Aberdeen Proving Ground, Maryland,

$(A)$ chloroform (CF), (B) tetrachloroethene (PCE), and (C) cis-1,2-dichloroethene (cis-1,2-DCE)

11. Graph showing vertical distribution of selected chlorinated volatile organic compunds at seep location 3-4W, West Branch Canal Creek, Aberdeen Proving Ground, Maryland, August 2003. 
12. Maps showing baseline distribution of total chlorinated volatile organic compounds at $(A)$ the top of the Canal Creek aquifer, and $(B)$ in wetland sediments beneath the seep 3-4W reactive mat pilot test area,

West Branch Canal Creek, Aberdeen Proving Ground, Maryland, August-September 2004.

13-14. Diagrams showing -

13. Section D-D' showing baseline mean hydraulic head distribution at the seep 3-4W reactive mat pilot test area, West Branch Canal Creek, Aberdeen Proving Ground, Maryland, August-September 2004, $(A)$ low tide and $(B)$ high tide..

14. Section E-E' showing baseline mean hydraulic head distribution at the seep 3-4W reactive mat pilot test area, West Branch Canal Creek, Aberdeen Proving Ground, Maryland, August-September 2004, (A) low tide and (B) high tide.

15. Map showing baseline planar distribution of hydraulic head in the upper wetland sediments at low tide, seep 3-4W reactive mat pilot test area, West Branch Canal Creek, Aberdeen Proving Ground, Maryland, September 2004

16-17. Diagrams showing-

16. Baseline distribution of chlorinated volatile organic compounds in section $Y^{-} Y^{\prime}$ at the seep 3-4W reactive mat pilot test area, West Branch Canal Creek, Aberdeen Proving Ground, Maryland, August-September 2004, (A) chloromethanes and $(B)$ chloroethenes plus chloroethanes..

17. Baseline distribution of chlorinated volatile organic compounds in section Z-Z' at the seep 3-4W reactive mat pilot test area, West Branch Canal Creek, Aberdeen Proving Ground, Maryland, August-September 2004, (A) chloromethanes and $(B)$ chloroethenes plus chloroethanes..

18-20. Graphs showing-

18. Methane concentrations in the reactive mat pilot test at seep area 3-4W, West Branch Canal Creek, Aberdeen Proving Ground, Maryland, (A) PTBC level, (B) PTBB level, and

(C) in profile at PTB7/PTC4

19. Concentrations of 1,1,2,2-tetrachloroethane (TeCA),

1,1,2-trichloroethane (TCA), trichloroethene (TCE),

trans-1,2-dichloroethene (trans-1,2-DCE), and

cis-1,2-dichloroethene (cis-1,2-DCE) in activity tests from the reactive mat pilot test at seep area 3-4W, West Branch

Canal Creek, Aberdeen Proving Ground, Maryland, (A) November 2004 and (B) March 2005

20. Concentrations of total volatile organic compounds at various depths in reactive mat porewater, seep 3-4W reactive mat pilot test area, West Branch Canal Creek, Aberdeen Proving Ground, Maryland, $(A)$ top of Canal Creek aquifer, $(B)$ wetland sediments 5 feet below land surface, $(C)$ immediately below the reactive mat (PTN), (D) top of the zero-valent-iron (ZVI) -organic (PTBC) zone within the reactive mat, and $(E)$ middle of the organic (PTBB) zone within the reactive mat 
21-22. Maps showing-

21. Planar distribution of chlorinated methanes below and within the reactive mat at the seep 3-4W pilot test area, West Branch Canal Creek, Aberdeen Proving Ground, Maryland, August 2005, $(A)$ aquifer, $(B)$ wetland sediments 8 feet below land surface, (C) wetland sediments 5 feet below land surface, (D) PTN level, (E) PTBC level, and (F) PTBB level.

22. Planar distribution of chlorinated ethenes and ethanes below and within the reactive mat at the seep 3-4W pilot test area, West Branch Canal Creek, Aberdeen Proving Ground, Maryland, August 2005, (A) wetland sediments 5 feet below land surface, (B) PTN level, and (C) PTBB level

23-25. Graphs showing-

23. Vertical distribution of total chlorinated volatile organic compounds below and within the reactive mat at the seep 3-4W pilot test area, West Branch Canal Creek, Aberdeen Proving Ground, Maryland, August 2004-September 2005, (A) PTC4 (southwest corner), (B) PTC2 (northeast corner), and (C) PTC5 (southeast corner)

24. Total chlorinated volatile organic compounds in selected perimeter piezometers at the seep 3-4W pilot test area, West Branch Canal Creek, Aberdeen Proving Ground, Maryland, $(A)$ south and $(B)$ north of reactive mat.

25. Vertical distribution of selected chlorinated volatile organic compounds below and within the reactive mat in the spring and summer at the seep 3-4W pilot test area site PTC4/PTB7, West Branch Canal Creek, Aberdeen Proving Ground, Maryland, $(A)$ chloroethenes and chloroethanes, March 2005,

(B) chloromethanes, March 2005, (C) chloroethenes and chloroethanes, June 2005, and (D) chloromethanes, June 2005

26. Maps showing surface elevations of reactive mat and surrounding area at seep 3-4W reactive mat pilot test area, West Branch Canal Creek, Aberdeen Proving Ground, Maryland, (A) October 2004 and (B) March 2005

27. Graphs showing vertical distribution of mean head elevation at low tide along two lines of section after reactive mat installation, West Branch Canal Creek, Aberdeen Proving Ground, Maryland, (A) D-D' and (B) E-E'

28a. Photograph showing thermal infrared image of the seep 3-4W reactive mat pilot test area, West Branch Canal Creek, Aberdeen Proving Ground, Maryland, 2005.

28b. Map showing total volatile organic compound concentrations detected in passive diffusion samplers installed following thermal infrared imaging of the seep 3-4W reactive mat pilot test area, West Branch Canal Creek, Aberdeen Proving Ground, Maryland, 2005..

29-30. Diagrams showing-

29. Vertical distribution of chloromethanes along line of section $Z-Z^{\prime}$, seep 3-4W reactive mat pilot test area, West Branch Canal Creek, Aberdeen Proving Ground, Maryland, August 2005.

30. Vertical distribution of chloromethanes along line of section $Y-Y^{\prime}$, seep 3-4W reactive mat pilot test area, West Branch Canal Creek, Aberdeen Proving Ground, Maryland, August 2005. 
31-33. Graphs showing-

31. Concentrations of total volatile organic compounds detected in perimeter piezometers, seep 3-4W reactive mat pilot test area, West Branch Canal Creek, Aberdeen Proving Ground, Maryland, August 2004-September 2005, (A) west of reactive mat and $(B)$ south of reactive mat.

32. Quality of wetland sediment porewater, seep 3-4W reactive mat pilot test area, West Branch Canal Creek, Aberdeen Proving Ground, Maryland, September 2004-05, $(A)$ pH in perimeter piezometers, $(B) \mathrm{pH}$ in under-mat samplers, $(C)$ specific conductance in perimeter piezometers, and $(D)$ specific conductance in under-mat samplers

33. Selected volatile organic compounds in surface water at the seep 3-4W reactive mat pilot test area, West Branch Canal Creek, Aberdeen Proving Ground, Maryland, (A) August 2004, (B) February 2005, and (C) June 2005

\section{Tables}

1. Piezometer and sampler screen depths from the seep $3-4 \mathrm{~W}$ reactive mat pilot test area, West Branch Canal Creek, Aberdeen Proving Ground, Maryland

2. Groundwater and surface-water sampling at the seep $3-4 \mathrm{~W}$ reactive mat pilot test area, West Branch Canal Creek, Aberdeen Proving Ground, Maryland, August 2004-September 2005

3. BioChlor input values for chloromethane, chloroethane, and chloroethene degradation in a model reactive mat

4. Calculated reactive mat tolerable thicknesses based on laboratory and field-determined unconfined shear strength of wetland sediments at seep 3-4W, West Branch Canal Creek, Aberdeen Proving Ground, Maryland

5. Sediment properties from reported successful in situ capping projects and wetland sediments at seep 3-4W, West Branch Canal Creek, Aberdeen Proving Ground, Maryland

6. Comparison of metal concentrations in native wetland sediment samples from seep 3-4W, West Branch Canal Creek, Aberdeen Proving Ground, Maryland, and in compost mixtures to consensus-based probable effect concentrations

7. Nutrient and organic matter content of composts used in this study 
8. Concentrations of methane and hydrogen from in-mat diffusion samplers, seep 3-4W reactive mat pilot test area, West Branch Canal Creek, Aberdeen Proving Ground, Maryland, December 2004-0ctober $2005 .$.

9. Estimated mass removal of chloromethanes and the sum of chloroethanes and chloroethenes through the zero-valent iron (ZVI) mix and organic-mix zones in the seep 3-4W reactive mat pilot test area, West Branch Canal Creek, Aberdeen Proving Ground, Maryland, November 2004-August 2005.

10. Comparison of water-level elevations at low and high tide in selected piezometers before deployment of the reactive mat (August-September 2004) to the mean water-level elevations measured after deployment (November 2004-September 2005), seep 3-4W pilot test area, West Branch Canal Creek, Aberdeen Proving Ground, Maryland.

\section{Conversion Factors and Abbreviations}

\begin{tabular}{lll}
\hline \multicolumn{1}{c}{ Multiply } & \multicolumn{1}{c}{ By } & \multicolumn{1}{c}{ To obtain } \\
\hline inch (in.) & 2.54 & centimeter $(\mathrm{cm})$ \\
foot $(\mathrm{ft})$ & 0.3048 & meter $(\mathrm{m})$ \\
square foot $\left(\mathrm{ft}^{2}\right)$ & 0.09290 & square meter $\left(\mathrm{m}^{2}\right)$ \\
foot per day $(\mathrm{ft} / \mathrm{d})$ & 0.0003048 & centimeter per second $(\mathrm{cm} / \mathrm{s})$ \\
foot per year $(\mathrm{ft} / \mathrm{yr})$ & 0.3048 & meter per year $(\mathrm{m} / \mathrm{yr})$ \\
cubic foot per second $(\mathrm{ft} / \mathrm{s} / \mathrm{s})$ & 0.02832 & cubic meter per second $\left(\mathrm{m}^{3} / \mathrm{s}\right)$ \\
gallon (gal) & 3.785 & liter $(\mathrm{L})$ \\
pound, avoirdupois $(\mathrm{lb})$ & 0.4536 & kilogram $(\mathrm{kg})$ \\
pound per cubic foot $\left(\mathrm{lb} / \mathrm{ft}^{3}\right)$ & 0.0160 & gram per cubic centimeter $\left(\mathrm{g} / \mathrm{cm}^{3}\right)$ \\
\hline
\end{tabular}

Other abbreviated units of measure: Water temperature, chemical concentrations, and other chemical and physical properties of constituents are given in metric units.

Temperature in degrees Celsius $\left({ }^{\circ} \mathrm{C}\right)$ may be converted to degrees Fahrenheit $\left({ }^{\circ} \mathrm{F}\right)$ as follows:

$$
{ }^{\circ} \mathrm{F}=\left(1.8 x^{\circ} \mathrm{C}\right)+32
$$

Temperature in degrees Fahrenheit $\left({ }^{\circ} \mathrm{F}\right)$ may be converted to degrees Celsius $\left({ }^{\circ} \mathrm{C}\right)$ as follows:

$$
{ }^{\circ} \mathrm{C}=\left({ }^{\circ} \mathrm{F}-32\right) / 1.8
$$

Concentrations of chemical constituents in water are given either in milligrams per liter (mg/L), micrograms per liter $(\mu \mathrm{g} / \mathrm{L})$, or micromoles per liter $(\mu \mathrm{M} / \mathrm{L})$. 



\title{
Design and Performance of an Enhanced Bioremediation Pilot Test in a Tidal Wetland Seep, West Branch Canal Creek, Aberdeen Proving Ground, Maryland
}

\author{
by Emily H. Majcher, Michelle M. Lorah, Daniel J. Phelan, and Angela L. McGinty
}

\section{Abstract}

Because of a lack of available in situ remediation methods for sensitive wetland environments where contaminated groundwater discharges, the U.S. Geological Survey, in cooperation with the U.S. Army Garrison, Aberdeen Proving Ground, Maryland, conceived, designed, and pilot tested a permeable reactive mat that can be placed horizontally at the groundwater/surface-water interface. Development of the reactive mat was part of an enhanced bioremediation study in a tidal wetland area along West Branch Canal Creek at Aberdeen Proving Ground, where localized areas of preferential discharge (seeps) transport groundwater contaminated with carbon tetrachloride, chloroform, tetrachloroethene, trichloroethene, and 1,1,2,2-tetrachloroethane from the Canal Creek aquifer to land surface. The reactive mat consisted of a mixture of commercially available organic- and nutrient-rich peat and compost that was bioaugmented with a dechlorinating microbial consortium, WBC-2, developed for this study. Due to elevated chlorinated methane concentrations in the pilot test site, a layer of zero-valent iron mixed with the peat and compost was added at the base of the reactive mat to promote simultaneous abiotic and biotic degradation.

The reactive mat for the pilot test area was designed to optimize chlorinated volatile organic compound degradation efficiency without altering the geotechnical and hydraulic characteristics, or creating undesirable water quality in the surrounding wetland area, which is referred to in this report as achieving geotechnical, hydraulic, and water-quality compatibility. Optimization of degradation efficiency was achieved through the selection of a sustainable organic reactive matrix, electron donor, and bioaugmentation method. Consideration of geotechnical compatibility through design calculations of bearing capacity, settlement, and geotextile selection showed that a 2- to 3-feet tolerable thickness of the mat was possible, with 0.17 feet settlement predicted for unconsolidated sediments between 1.5 and 6 years following installation of the reactive mat. To ensure hydraulic compatibility in the mat design, mat materials that had a hydraulic conductivity greater than the surrounding wetland sediments were selected, and the mixture was optimized to consist of 1.5 parts compost, 1.5 parts peat and 1 part sand as a safeguard against fluidization. Sediment and matrix properties also indicated that a nonwoven geotextile with a cross-plane flow greater than that of the native sediments was suitable as the base of the reactive mat. Another nonwoven geotextile was selected for installation between the iron mix and organic zones of the mat to create more laminar flow conditions within the mat. Total metals and sequential extraction procedure analyses of mat materials, which were conducted to evaluate water-quality compatibility of the mat materials, showed that concentrations of metals in the compost ranged from one-half to one order of magnitude below consensus-based probable effect concentrations in sediment.

A 22-inch-thick reactive mat, containing 0.5 percent WBC- 2 by volume, was constructed at seep area $3-4 \mathrm{~W}$ and monitored from October 2004 through October 2005 for the pilot test. No local, immediate failure of the mat or of wetland sediments was observed during mat installation, indicating that design estimates of bearing capacity and geotextile textile selection ensured the integrity of the mat and wetland sediments during and following installation. Measurements of surface elevation of the mat showed an average settlement of the mat surface of approximately 0.25 feet after 10 months, which was near the predicted settlement for unconsolidated sediment.

Monitoring showed rapid establishment and sustainment throughout the year of methanogenic conditions conducive to anaerobic biodegradation and efficient dechlorination activity by WBC-2. The median mass removal of chloromethanes and total chloroethenes and ethane during the performance monitoring period was 98 and 94 percent, respectively, within the 1.5 -feet-thick zone between the base of the mat and the middle of the organic zone, whereas no mass removal was observed within the underlying 12-15-feet-thick wetland sediment in the seep area. Following mat installation, transient appearance of daughter volatile organic compounds, including trichloroethene, cis-1,2-dichloroethene, vinyl chloride, and methylene chloride, was observed in groundwater in the mat in association with decreasing concentrations of parent volatile organic compounds. In some areas of the mat, the non-toxic end products of ethene and ethane were consistently detected 
throughout the monitoring period. An apparent decrease in volatile organic compound degradation and methane production occurred in late winter to early spring, consistent with a decline in microbial activity during the colder months. Waterquality monitoring for $\mathrm{pH}$, specific conductance, nutrients, major ions, and metals indicated that the mat had no adverse effect on the groundwater quality in the wetland sediments surrounding the reactive mat, nor on nearby surface-water quality.

Hydraulic head gradients ( 0.20 to 0.26 feet/feet $)$ in and around the reactive mat remained dominantly vertically upward following mat installation, consistent with pre-installation calculations. Horizontal hydraulic gradients remained at least one to two orders of magnitude lower than the vertical hydraulic head gradients. Despite the dominantly vertically upward head gradients in the mat, an aerial thermal infrared flight during winter 2005 showed that the reactive mat was not warmer than surrounding wetland sediments, as observed on flights over the seep area prior to mat installation. Observed seep areas in the vicinity of seep $3-4 \mathrm{~W}$ were consistent with previous flight imagery, however, and porewater sampling indicated that transport of volatile organic compounds had not shifted to these nearby seep areas as a result of the mat installation. This indicates that the design goal of normalizing flow across the mat area without affecting flow in the surrounding wetland was achieved.

Overall, the pilot test showed that the design goal of at least 90 percent mass removal of total chlorinated volatile organic compounds was achieved and maintained for 1 year in the reactive mat without any undesired geotechnical, hydraulic, or water-quality effects on the wetland and tidal creek. Additional monitoring, however, would be necessary to evaluate long-term sustainability of enhanced biodegradation in the mat. Future applications would benefit from either deeper placement within the native sediments or a thinner mat to minimize final elevation of the mat above land surface.

\section{Introduction}

A study of the design of a reactive mat for enhanced bioremediation at the groundwater/surface-water interface and demonstration of its performance in a pilot test was completed by the U.S. Geological Survey (USGS), in cooperation with the U.S. Army Garrison, Aberdeen Proving Ground (APG). The West Branch Canal Creek study area, the location of the performance pilot test demonstration, is the focus of ongoing Remedial Investigation and Feasibility Study efforts for the Installation Restoration Program (IRP) at APG, in accordance with the U.S. Environmental Protection Agency (USEPA) Superfund Program (fig. 1a).

Wetlands are a natural transition zone between groundwater and surface water (Winter and others, 1998; Mitsch and Gosselink, 1993). Wetland sediments have been shown to have the ability to efficiently naturally attenuate chlorinated solvents in porewater (Lorah and others, 1997; Lorah and Olsen, 1999; CFR Technical Services, 2005) when acting as receptors of contaminated groundwater discharge. In heterogeneous wetland systems, discrete pathways for solute transport to surface water can occur by preferential flow in the form of springs or seeps (Harvey and others, 1995; Portnoy and others, 1998; Winter and others, 1998; Conant and others, 2004). In cases where underlying groundwater is contaminated, seeps can provide a route for contaminants to migrate into surface water (Conant and others, 2004; Majcher and others, 2007) and reach human and ecological receptors.

Where chlorinated volatile organic compound (VOC) plumes discharge to the West Branch Canal Creek bottom sediments and wetlands from an aerobic, sand and gravel aquifer, natural attenuation in anaerobic wetland sediments appears to efficiently reduce concentrations in most of the wetland area throughout the year (Lorah and others, 1997, 2003; Lorah, Spencer, and McGinty, 2005; Majcher and others, 2007). Seep areas have been identified, however, where natural attenuation of chlorinated solvents by anaerobic biodegradation is hindered by the increase in vertical seepage flux and the resulting decrease in residence time in the wetland sediments (Majcher and others, 2007) (fig. 1b). This hydrologic occurrence results in more oxidizing conditions, an accumulation of chlorinated VOCs, and in some cases, a change in the microbial community in wetland porewater (Majcher and others, 2007). Although seeps of contaminated porewater to surface water are limited to approximately 1 percent of the total discharge area along the West Branch Canal Creek, they contribute approximately 20 percent of the total volume discharge of groundwater to surface water and contain up to $35 \mathrm{ppm}$ (parts per million) of total chlorinated VOCs near the groundwater/ surface-water interface (Majcher and others, 2007).

Chlorinated VOCs in groundwater in the West Branch Canal Creek study area include 1,1,2,2, tetrachloroethane (TeCA), hexachloroethane (HCA), pentachloroethane (PCA), trichloroethene (TCE), carbon tetrachloride (CT), chloroform (CF), and tetrachloroethene (PCE) from historical use and disposal during military manufacturing and research activities in the area (Nemeth, 1989; Lorah and Clark, 1996). These compounds, many of which are common to other industrial and military sites, can be converted to non-toxic compounds by abiotic and microbially mediated degradation reactions under anaerobic conditions (figs. 2a,b).

In cases where sources of chlorinated VOCs are near or beneath the existing wetland sediments, traditional remediation technologies become infeasible due to logistical constraints, particularly if a complementary goal of the remediation is compatibility, defined in this report as having minimal adverse effect on the surrounding wetland ecosystem. Some approaches used for chlorinated VOC remediation such as pump-and-treat and chemical oxidation, have the potential to adversely impact the downgradient wetland ecosystem. For this USGS study, enhanced bioremediation approaches were investigated, with the goal of duplicating the previously documented natural processes in other areas of the wetland in 


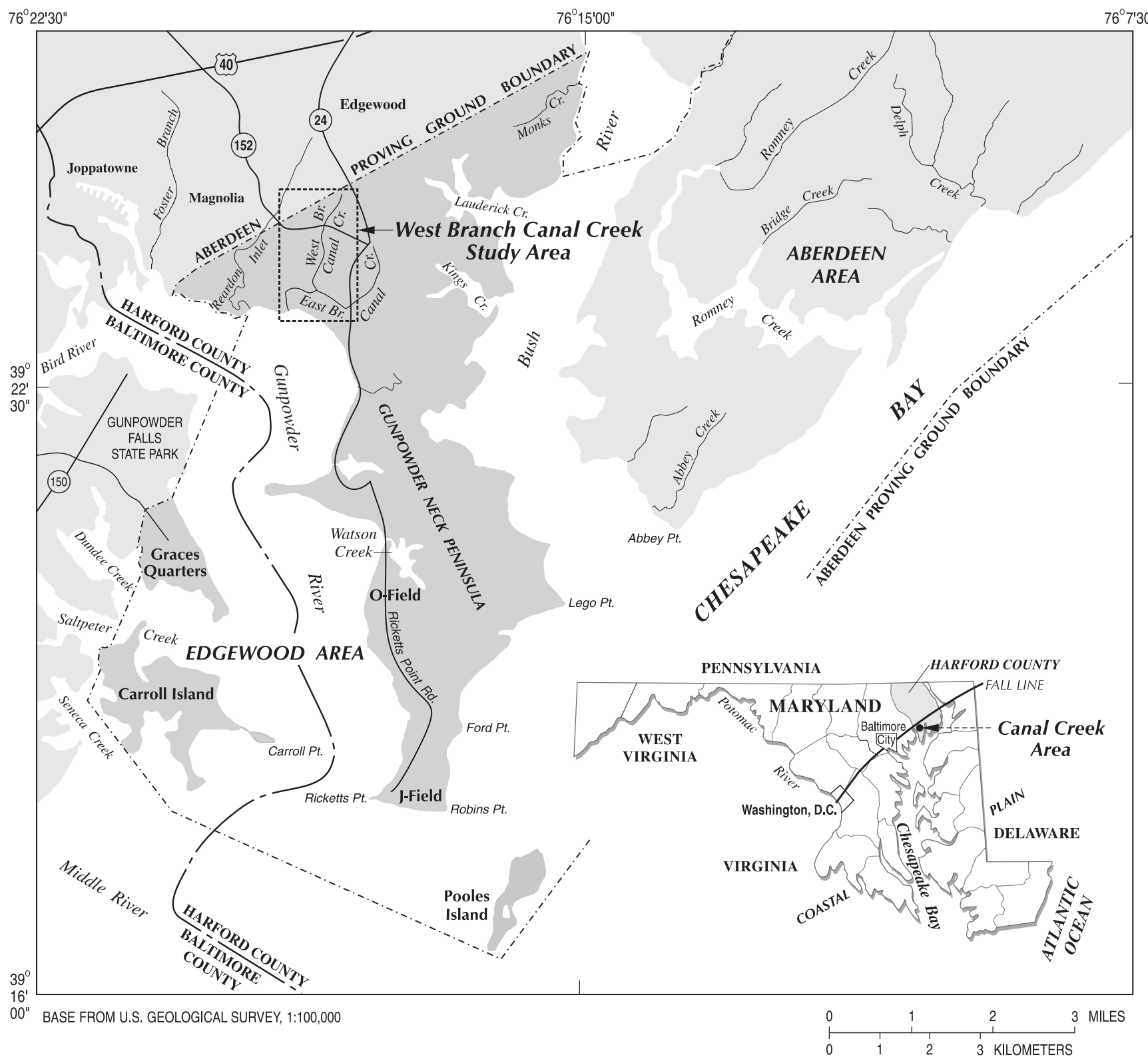

Figure 1a. Location of the West Branch Canal Creek study area, Aberdeen Proving Ground, Maryland (modified from Phelan and others, 2002).

the seep areas. Two enhanced bioremediation methods, both of which involved biostimulation [addition of a favored electrondonor substrate and (or) nutrients] with or without bioaugmentation (addition of degrading microorganisms), were studied first in laboratory experiments - direct injection into the wetland sediments and the installation of a permeable reactive mat (Lorah and others, 2008). If logistical constraints such as delivery of amendments to the subsurface and site access can be overcome, enhanced bioremediation is a desirable treatment method for seep areas.
This study developed the methods for and demonstrated in situ remediation with the reactive mat at a chlorinated VOC-contaminated seep area along West Branch Canal Creek. USGS conceptualized and developed a permeable, biologically reactive mat to be placed horizontally at the seep surface and create a zone of enhanced degradation for the upward-flowing groundwater before the contaminants reach the surface water. The components of the reactive mat, selected during the laboratory investigation, included commercially available compost and peat that were bioaugmented with a newly developed 


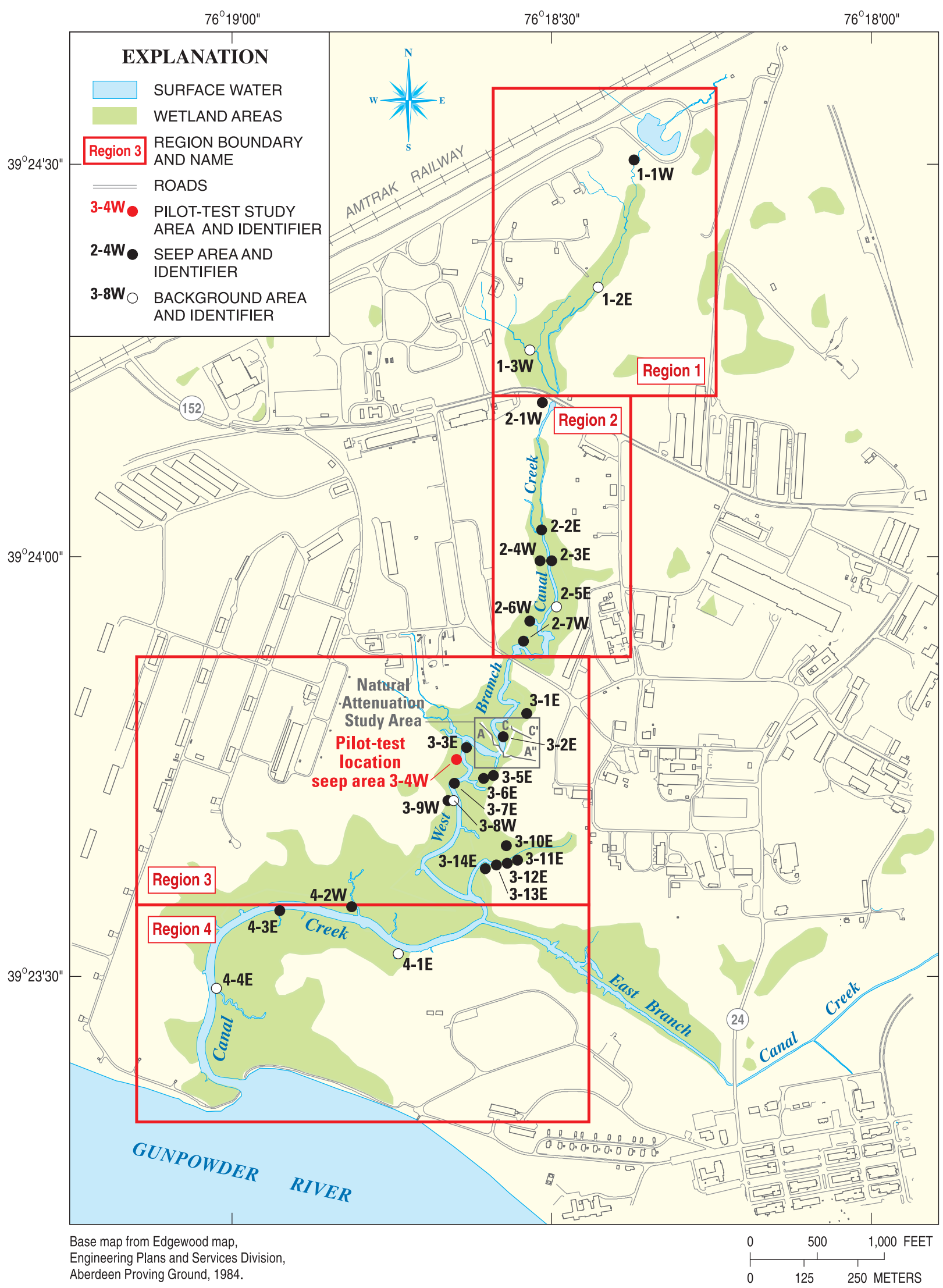

Figure 1b. Location of pilot-test seep and natural attenuation study areas, West Branch Canal Creek, Aberdeen Proving Ground,Maryland (modified from Majcher and others, 2007). 
microbial consortium, WBC-2, capable of dechlorinating the suite of chlorinated VOCs in this wetland environment (Jones and others, 2006; Lorah and others, 2008). The objectives of this study were to (1) develop the site-specific design of the reactive mat at a contaminated seep area along West Branch Canal Creek, (2) implement a pilot-scale demonstration of the reactive mat at the seep area, and (3) evaluate the performance of the pilot-scale demonstration over 1 year.

\section{Purpose and Scope}

The purpose of this report is to describe the design and performance of an enhanced bioremediation pilot test at seep area 3-4W along West Branch Canal Creek (fig. 1b). The overall design framework and performance metrics at seep $3-4 \mathrm{~W}$ are presented. Field and laboratory investigations that were conducted in support of the primary design objectives, degradation optimization, and determination of compatibility with the hydraulic, geotechnical, and water-quality characteristics of the wetland are described. The synthesis of results from these investigations is discussed and presented in a site-specific design. Specifically, results of hydraulic, geotechnical, and water-quality investigations were used to estimate the allowable thickness and reactive matrix composition to maximize removal of VOCs as they passed through the mat. Performance was evaluated using specially designed monitoring devices to measure various performance parameters in and around the reactive mat. Results that describe the reactive mat degradation efficiency and compatibility also are presented.

The reactive mat design for seep $3-4 \mathrm{~W}$ was finalized using an iterative design process in which a maximum tolerable thickness was calculated based on the hydraulic, geotechnical, and water-quality constraints for the site and the ability to remove chlorinated VOCs. Degradation rates of parent compounds, transient removal of daughter compounds, and the optimal conditions for survival of the bioaugmented microbial consortium, WBC-2, were evaluated to predict the mass removal of VOCs reaching surface water in the seep area using a one-dimensional model. An analysis of bearing capacity and primary settlement are presented as part of the design based on an investigation conducted in spring 2004.

The overall performance of the reactive mat at seep 3-4W from October 2004 through October 2005 is discussed relative to the design goals. Sampling results for VOCs below and within the mat are presented and mass removal of VOCs reaching surface water is discussed. Oxidation-reduction (redox) conditions within the mat and their impact on WBC-2 activity also are discussed. Analysis of the potentiometric surface surrounding the reactive mat, vertical gradients, and aerial thermal infrared (TIR) analysis of the pilot test area were used to assess hydraulic compatibility. Planar surface elevations of the mat were compared to predicted settlement over time to evaluate the geotechnical compatibility of the reactive mat. Finally, sampling results for VOCs, metals, and nutrients were used to evaluate the overall impact of the reactive mat on native porewater surrounding the mat and on surface-water quality.

\section{Description of Study Area}

The pilot test was conducted within the USGS seep study area (Majcher and others, 2007) in the northwest section of the Edgewood Peninsula of APG near the northwest reaches of the Chesapeake Bay at seep 3-4W, on the western perimeter of the West Branch Canal Creek (figs. 1a, b). The USGS study areas (including the pilot test) are wholly encompassed by the APG IRP-designated West Canal Creek Study Area (Weston Solutions, 2005). The main industrial part of the West Canal Creek study area was located to the east of the creek and is considered the likely source of chlorinated solvent groundwater contamination detected in the underlying aquifer and the downgradient freshwater, tidal wetlands (Lorah and Clark, 1996), including seep 3-4W. The pilot test area was located downstream of previous USGS investigations of natural attenuation processes (natural attenuation study area, fig. 1b).

The regional geology of the USGS study areas was previously characterized and described (Oliveros and Vroblesky, 1989; Lorah and others, 1997; Weston Solutions, 2005). The Canal Creek aquifer of the Patapsco Formation is largely unconfined near the West Branch Canal Creek wetland and stream. Soft, organic-rich sediments comprise the wetland and stream bottom. Physical and chemical characteristics of these sediments have also been described previously (Lorah and others, 1997; Olsen and others, 1997; Phelan, Senus, and Olsen, 2001; Majcher and others, 2007).

Preferential seepage of contaminated groundwater from the aquifer to West Branch Canal Creek was identified as the major transport mechanism of VOCs to surface water (Majcher and others, 2007). Generally, porewater in seep areas contaminated with chlorinated VOCs had less reducing conditions and greater VOC concentrations than porewater in non-seep wetland sediments. Seep locations characterized as focused seeps contained the highest concentrations of chlorinated parent compounds, relatively low concentrations of chlorinated daughter compounds, and insignificant concentrations of methane in shallow porewater samples. These seeps were primarily along the creek edge or formed a dendritic-like pattern between the wetland and creek channel. In contrast, seep locations characterized as diffuse seeps contained relatively high concentrations of chlorinated daughter compounds (or a mixture of daughter and parent compounds) and detectable methane concentrations in shallow porewater samples. These seeps were primarily along the wetland boundary (Majcher and others, 2007).

The USGS identified site characteristics that were desirable for the pilot test on the basis of the seep investigation that helped define hydrologic and redox characteristics, and VOC distribution in sediments within seep 3-4W (Majcher and others, 2007). Seep 3-4W was characterized as a focused discharge seep, with a seepage flux up to a maximum of $34 \mathrm{ft} / \mathrm{yr}$ (feet per year), during mid- to low-tidal range, which is about 37 times greater than flux estimates in the non-seep areas of the wetland (Lorah and others, 1997). The geometric mean of multiple measurements during various tidal ranges was 


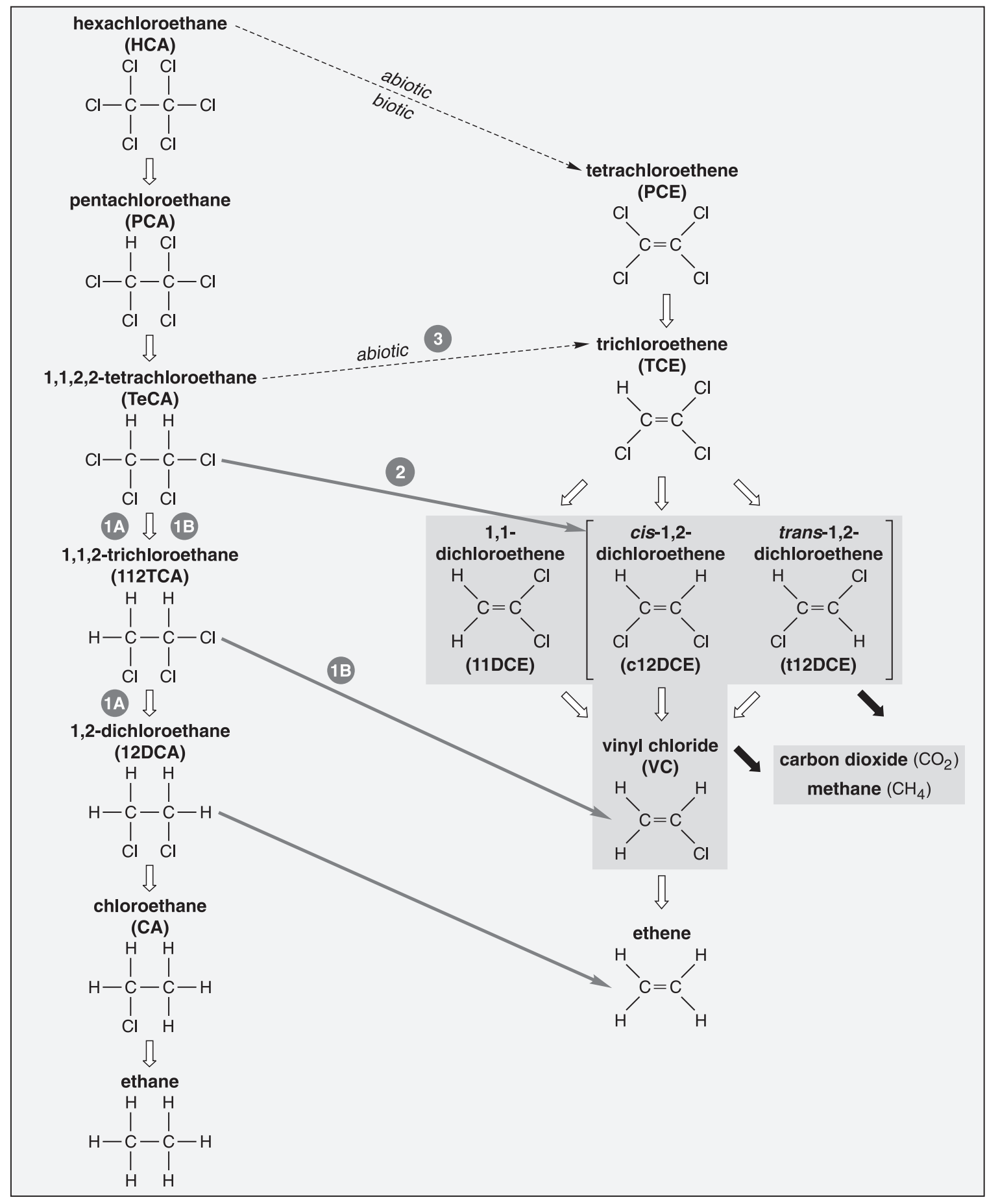

\section{Pathways of TeCA degradation: \\ (1A) TeCA HYDROGENOLYSIS TO 112TCA AND 12DCA \\ 18. TECA HYDROGENOLYSIS TO 112TCA FOLLOWED BY \\ $1 B$ DICHLOROELIMINATION OF 112TCA TO VC \\ 2 TeCA DICHLOROELIMINATION TO C12DCE AND T12DCE \\ 3 TeCA DEHYDROCHLORINATION TO TCE}

\section{EXPLANATION}

ANAEROBIC OXIDATION

II HYDROGENOLYSIS

$\downarrow$ DICHLOROELIMINATION

DEHYDROCHLORINATION

Figure 2a. Anaerobic degradation pathways for tetrachloroethene, trichloroethene, hexachlororethane, and 1,1,2,2-tetrachloroethane (modified from Lorah and others, 1997). 


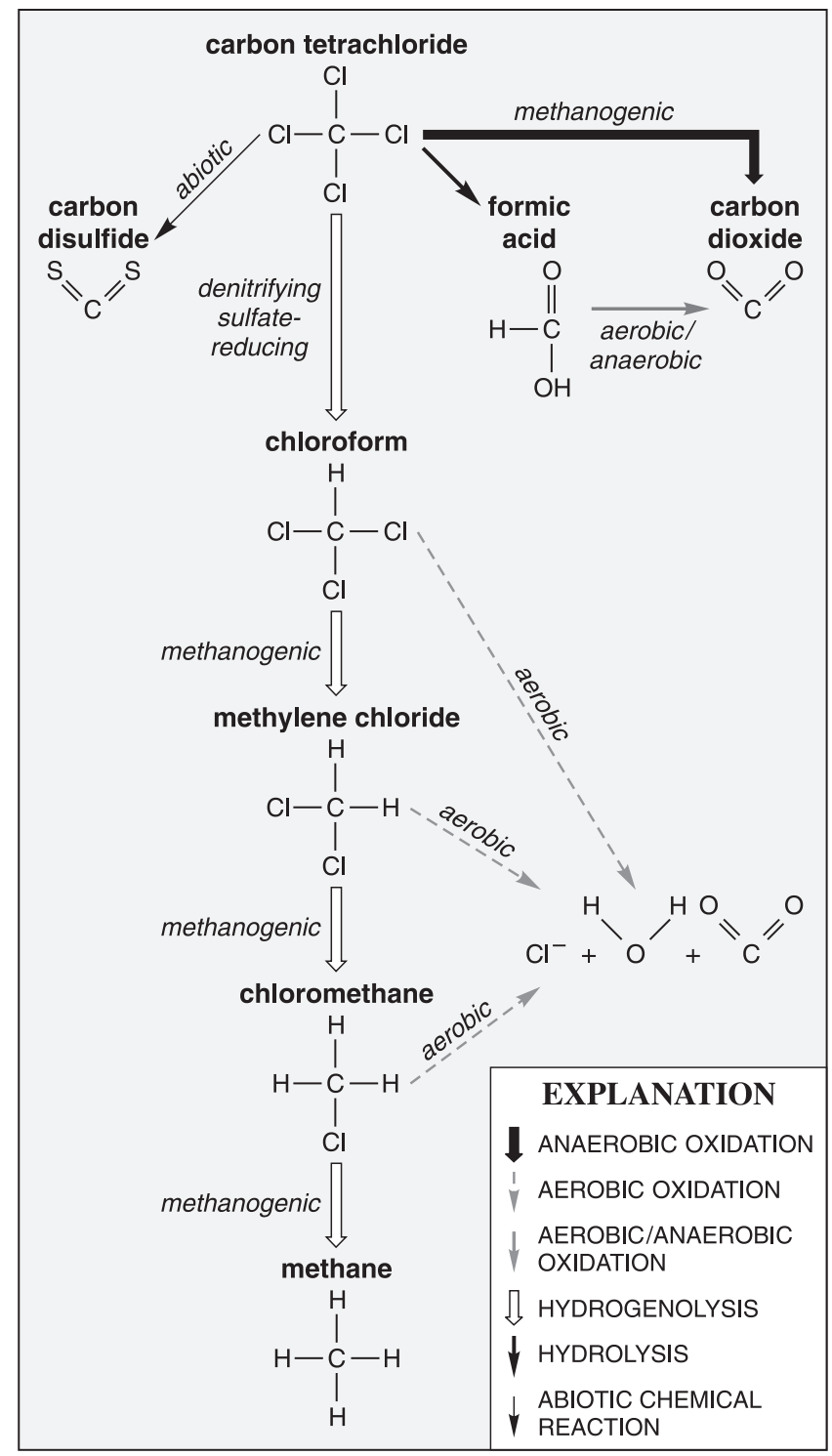

Figure 2b. Anaerobic and aerobic degradation pathways for carbon tetrachloride (modified from Majcher and others, 2007).

$19 \mathrm{ft} / \mathrm{yr}$, or about 20 times greater than the non-seep area estimates. Similarly, estimates of vertical hydraulic conductivity were calculated to be at least two orders of magnitude greater than non-seep sediments, averaging $66 \mathrm{ft} / \mathrm{yr}$ (to a maximum of $88 \mathrm{ft} / \mathrm{yr}$ ). In situ estimates of horizontal hydraulic conductivity ranged from 0.33 to $15 \mathrm{ft} / \mathrm{yr}$ (Majcher and others, 2007).

The depth to the Canal Creek aquifer in the vicinity of seep 3-4W was consistent with depths reported previously in nearby HP05 and HP11 (Phelan, Senus, and Olsen, 2001). The depth to the aquifer varied from the north to the south, ranging from about 12 to $15 \mathrm{ft}$ (Majcher and others, 2007). Lithologic descriptions of organic sediments within seep 3-4W were consistent with those described elsewhere in West Branch Canal Creek (Olsen and others, 1997; Phelan, Senus, and
Olsen, 2001). There was no visible evidence of preferential flowpaths. Similarly, other physical properties of the seep sediments (total organic carbon, grain size) were not indicative of preferential flowpaths (Majcher and others, 2007).

The hydrologic occurrence of rapid or focused discharge at seep 3-4W influenced anaerobic biodegradation of the various chlorinated solvents present in the wetland porewater (Majcher and others, 2007). Whereas anaerobic conditions were present, sulfide and methane were not detected in substantial quantities in the upper 2 to $4 \mathrm{ft}$ of wetland sediments. Rather, seep 3-4W supported predominantly iron-reducing conditions in the upper sediments and also accumulated ammonia. Both lateral and vertical delineation of chlorinated VOCs indicated that under these redox conditions, minimal anaerobic biodegradation occurs (Majcher and others, 2007). Concentrations of parent VOC compounds CF, CT, and PCE occupy a similar spatial footprint (approximately 1,000 square feet), in which concentrations of individual contaminants range from 15,000 to less than $100 \mu \mathrm{g} / \mathrm{L}$ (micrograms per liter) over as little as $10 \mathrm{ft}$ (feet) (and not greater than $20 \mathrm{ft}$ ) within the seep footprint. The increased velocity and corresponding decreased residence time in the wetland seep sediments results in a lack of anaerobic biodegradation, as indicated by the conservation of CF, CT, and PCE contaminant mass along vertical flowpaths in the wetland sediments. In some cases, an accumulation of mass is apparent with decreasing depth bls (below land surface), indicating that flow may not be entirely vertical in this area and that the seep may accumulate VOCs from the surrounding area. Discharge of the accumlated chlorinated VOCs and a lack of biodegradation results in an increased contaminant mass flux to surface water compared to non-seep wetland sediments (Majcher and others, 2007).

The overall land-surface slope of the seep 3-4W area was evaluated along two transects ( $N-N^{\prime}$ and $\left.M-M^{\prime}\right)$ from the area of maximum seepage and contamination and across the main channel of West Branch Canal Creek. The slope profiles, which extend from west to east across the creek, are shown in figure 3 . The area is relatively flat (minimally sloped) and is offset from the center of the channel, providing some protection from erosive forces.

\section{Background on Reactive Mat Technology Development}

A diagram showing the conceptual model for the receptor-targeted, reactive mat technology is presented in figure 4. This conceptual model incorporated principles of existing technologies including anaerobic bioremediation, in situ capping, and constructed or restored wetlands. The similarities and differences of these existing technologies to the reactive mat are summarized in this section. In addition, background microbial consortium development and bench tests for the reactive mat technology reported elsewhere (Jones and others, 2006; Lorah and others, 2008) also are summarized. 


\section{Basis in Existing Technologies}

Anaerobic, engineered bioremediation has become a widely accepted practice for in situ aquifer remediation of particular chlorinated solvents (Air Force Center for Environmental Excellence, 2004; Environmental Security Technology Certification Program, 2005). Biostimulation, or the addition of organic substrate or nutrients to the subsurface, facilitates conditions favorable to reductive dechlorination of these compounds. Numerous organic substrates in both liquid (such as lactate) and solid (such as chitin) forms are widely available (Lorah and others, 2008). Addition of these substrates typically creates a highly reducing environment that encourages the growth of native microorganisms capable of reductive dechlorination. In addition to promoting the abiotic reduction of various chlorinated compounds, zero-valent iron (ZVI) can generate hydrogen to support the anaerobic biodegradation of some chlorinated VOCs (Novak and others, 1998; Weathers and others, 1997).

Under some circumstances, biostimulation alone does not appear to facilitate the complete dechlorination to nonchlorinated end-products, resulting in accumulation of cis-1,2dichloroethene (cis-1,2-DCE) or other chlorinated daughter products. Similarly, there may be instances where there is a need to increase rates of dechlorination beyond those achieved with biostimulation. In these cases, bioaugmentation, or the addition of a known dechlorinating consortium to the subsurface, may be considered in combination with biostimulation. Currently, there are at least four commercially available mixed cultures capable of degrading PCE or TCE by reductive dechlorination at various stages of maturity in the presence of a preferred organic substrate (Environmental Security Technology Certification Program, 2005). Dehalococcoides bacteria, known to degrade vinyl chloride (VC) to ethene, are contained in each of these commercially available consortia and are strictly anaerobic. These cultures do not readily degrade chlorinated ethanes or methanes, although there is a commercially available culture that will degrade 1,1,2-trichloroethane (1,1,2-TCA) and 1,2-dichloroethane(1,2-DCA) (Environmental Security Technology Certification Program, 2005). Mixtures of ethane or methane compounds with ethenes typically inhibit the degradation activity of these various cultures, however (Bagley and others, 2000; Weathers and Parkin, 2000).

Preferential discharge of contaminated groundwater in seeps results in high concentrations near the groundwater/ surface-water interface. Maximum contaminant mass removal within a minimal barrier thickness is desirable. The use of non-native materials and the desire for rapid rates of degradation required inclusion of a mixed culture capable of complete dechlorination of mixed chlorinated methanes, ethanes, and ethenes near the wetland surface. Due to the lack of a commercially available culture for this application at the time of the pilot test, a culture was specifically developed as part of this study (see next section on Reactive Mat Laboratory Tests).
On the basis of earlier natural attenuation studies conducted at West Branch Canal Creek wetlands (Lorah and others, 1997; Lorah and Olsen, 1999), interest in constructed and restored wetlands for treatment of chlorinated VOCs grew (Pardue, 2002; Kassenga and others, 2003; Richard and others, 2001) due to the wetlands' inherent abilities to generate conditions favorable to anaerobic biodegradation. Using commercially available organic materials mixed with sand, Kassenga and others (2003) and Pardue (2002) demonstrated effective treatment of chlorinated VOCs with constructed wetland material in column tests. On the basis of VOC degradation rates measured in the columns and adjusted for potential decline in rates due to temporal changes, a required sediment thickness of more than $6 \mathrm{ft}$ was estimated for a constructed treatment wetland to meet drinking-water standards (Kassenga and others, 2003). Subsequent studies by CFR Technical Services (2005) and Kassenga and others (2004) indicated that the long-term circulation of groundwater and site contaminants to the column matrix resulted in enrichment of a mixed culture containing Dehalococcoides-related organisms, increasing the rate of removal of TeCA, TCE, cis-1,2DCE, and 1,2-DCA in this matrix. These constructed wetland matrices were desirable for application in a reactive mat due to their similarity to natural wetland sediments (including high organic matter content). In addition, because biodegradation was desired over as minimal a thickness as possible and with minimal delay after installation of the mat, bioaugmentation of the matrix was required.

Richard and others (2001) reported a more empirical approach to wetland restoration for chlorinated VOC remediation at a preferential flowpath in a small, dredged channel of a lake. Using degradation rates reported elsewhere, they encompassed the dredged channel into a nearby, existing wetland. In addition, constructed wetland cells have been reported for chlorinated VOC remediation, although VOC removal processes were not documented (Haberl and others, 2003; Clemmer, 2003).

Subaqueous, passive, and active caps have recently been utilized as an in-place containment alternative for ex situ sediment remediation alternatives such as dredging (Palermo and others, 1998). Active caps contain a reactive media, as does the reactive mat for this study, but are typically targeted to contain (or treat) hydrophobic contaminants associated with sediment such as metals, polychlorinated biphenyls (PCBs), and polyaromatic hydrocarbons (PAHs) (Palermo and others, 1998). Bench tests and field demonstrations of various active capping materials (AquaBlock, apatite, coke, ZVI, activated carbon, and sorbents) have been conducted (Reible and others, 2006). Geotechnical guidance developed for in situ capping was utilized for the reactive mat since the two technologies have similar design challenges in that they both require placing non-native material on soft, often subaqueous contaminated sediments that possess low shear strength and are in a possible high energy (such as a tidal) environment (Palermo and others, 1998). 

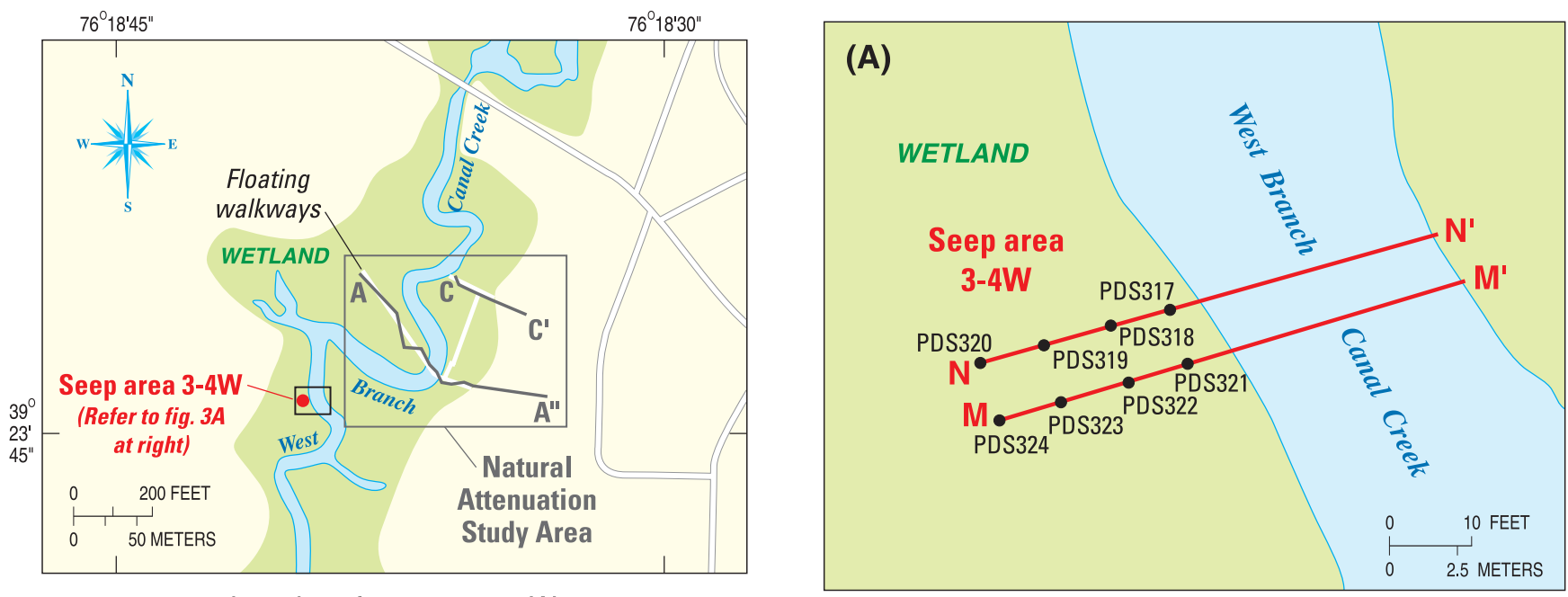

Location of seep area 3-4W.
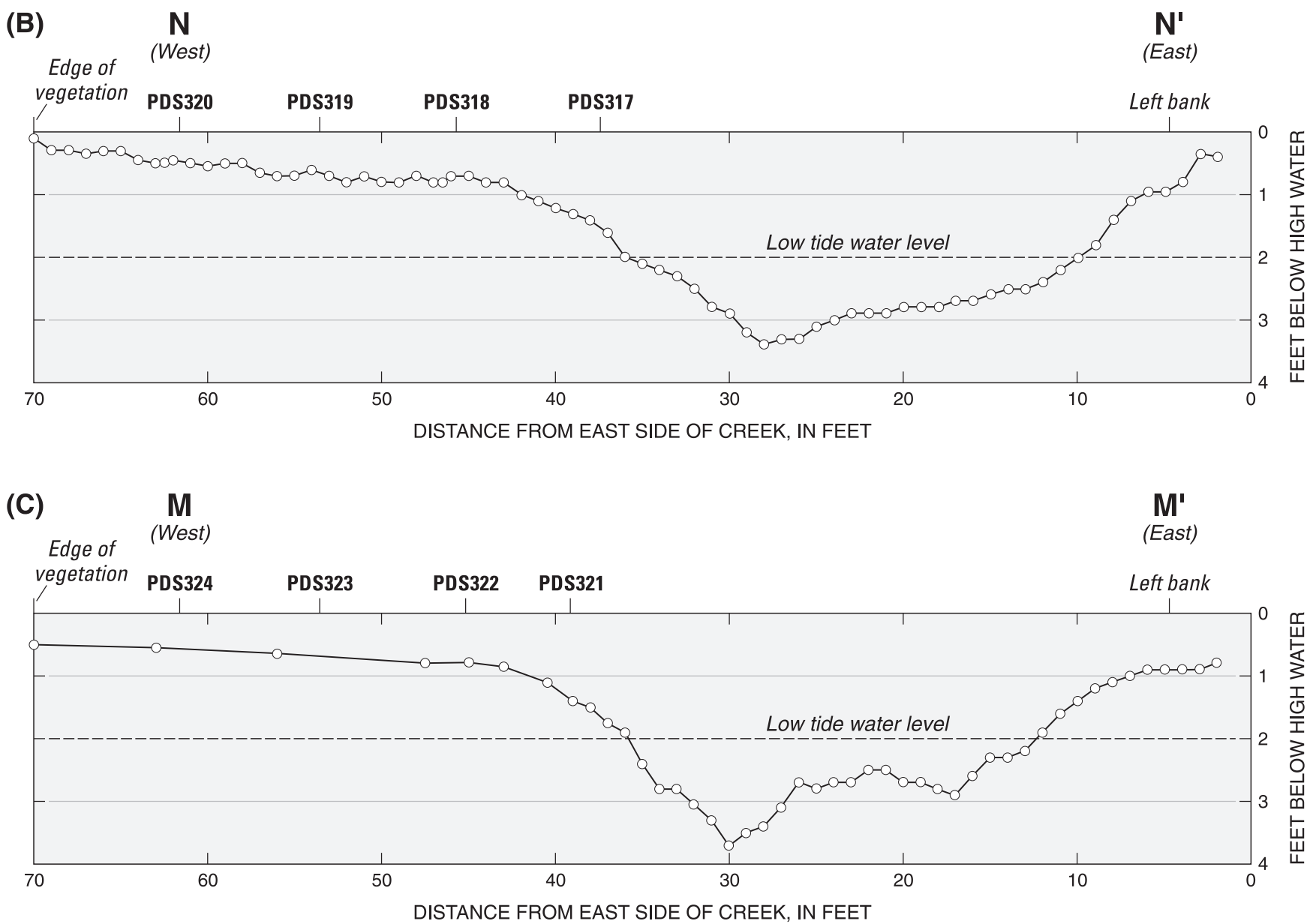

EXPLANATION

PDS320• PASSIVE-DIFFUSION SAMPLER LOCATION AND IDENTIFICATION NUMBER

Figure 3. Lines of section N-N' and M-M' showing slope of wetland surface along two transects within seep area 3-4W, West Branch Canal Creek, Aberdeen Proving Ground, Maryland, $(A)$ location of lines of section, $(B)$ transect N-N', and $(C)$ transect M-M'. 


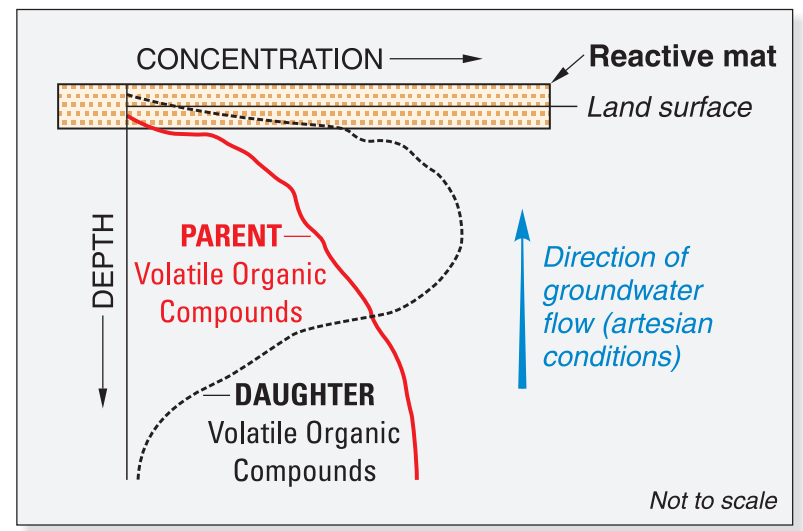

Figure 4. Conceptual model of a reactive mat.

Microbial mats, comprised of self-associating bacteria that do not require the use of a solid support matrix, also have been tested at the bench and pilot scale for biosorption and degradation of PCE and TCE (O'Niell and others, 1999). The commercially available "Biomats" ("microbial aquatic treatment systems") have been suggested for use in aqueous (such as ponds or bioreactors) as well as non-aqueous systems (Planteco Environmental Consultants, written commun., 2005; O'Niell and others, 1999). The microbial community in the "Biomats" is reported to be self-sustaining so that continual addition of microorganisms is not needed for long-term contaminant treatment. Ideally, inoculation of the reactive mat matrix will only be required at installation.

\section{Reactive Mat Laboratory Tests}

Results from a series of bench scale tests (Lorah and others, 2008; Geosyntec Consultants, Inc., 2004, 2007; Jones and others, 2006) contributed to the development of the reactive mat technology used at seep $3-4 \mathrm{~W}$ and are summarized in this section. The need to bioaugment the reactive mat was predicated by the need to maximize chlorinated solvent mass removal while minimizing mat thickness. As described previously, no known commercially available consortia were capable of achieving these goals. A microbial consortium (WBC-2) was developed by the USGS using enrichment techniques from wetland sediments collected from West Branch Canal Creek (Jones and others, 2006; Lorah and others, 2008). WBC-2 can completely dechlorinate TeCA and its chlorinated daughter products, including 1,1,2-TCA, cis-1,2-DCE, and VC (fig. 2a). In collaboration with the USGS, larger quantities of the WBC-2 were grown for the pilot test by SiREM Laboratory (Guelph, Ontario), a division of Geosyntec Consultants (Geosyntec Consultants, Inc., 2007).

Physiological characteristics of WBC-2 that were important for the reactive mat application were determined in batch tests, including electron donor and $\mathrm{pH}$ preference and oxygen tolerance (Geosyntec Consultants, Inc., 2007; Lorah and others, 2005a, 2005b). Testing with various commercially available electron donors showed that dechlorination rates were most rapid with chitin, which is a relatively insoluble donor comprised of crushed shells, and the soluble donors ethanol and lactate (Geosyntec Consultants, Inc., 2007; Lorah and others, 2005a). The enhancement of dechlorination rates with both insoluble and soluble donors provides flexibility for applications of the reactive mat. The wetland porewater at seep 3-4W is acidic, with $\mathrm{pH}$ typically less than 5 (Majcher and others, 2007), but the organic matrix tested for the reactive mat was thought likely to cause an increase in $\mathrm{pH}$. WBC-2 was able to maintain complete dechlorination of added TeCA, 1,1,2-TCA, and cis-1,2-DCE under acidic (pH 5) to alkaline (pH 9) conditions (Lorah and others, 2005b; Geosyntec Consultants, Inc., 2007), indicating that the mat could be effective over a wide range of operational conditions.

Typically, microorganisms capable of reductive dechlorination (specifically Dehalococcoides-related organisms) are highly sensitive to the presence of oxygen, making the reactive mat inoculation and viability at the groundwater/ surface water interface a challenge. Oxygen sensitivity of WBC-2 was tested by bubbling ambient air through an aliquot for designated timeframes. Following timed exposures to ambient air, culture media was purged with anaerobic gas and dechlorination of TeCA, 1,1,2-TCA, and cis-1,2-DCE was evaluated. Dechlorination after 20 minutes of exposure was comparable to culture with no exposure to oxygen at all, while after 60 minutes, activity was temporarily inhibited before proceeding to completion (Lorah and others, 2005b; Geosyntec Consultants, Inc., 2007).

Concurrent with the characterization of the culture, bench scale tests were completed with wetland sediments and reactive matrices to evaluate dechlorination ability using biostimulation and bioaugmentation (Lorah and others, 2008). Bioaugmentation with WBC-2 increased degradation rates of chlorinated ethanes in wetland sediments at least two-fold in microcosms conducted with sediment collected during different seasons. This same enhancement of the degradation rate was not observed when biostimulation (addition of nutrients or soluble organic substrates) was tested without the addition of WBC-2 (Lorah and others, 2008).

Mixtures of peat, various compost types, and sand were evaluated as an organic matrix for the reactive mat in anaerobic laboratory microcosms and columns (Lorah and others, 2008). The first mixture that was evaluated was based on extensive laboratory testing reported on materials used in constructed wetlands by Kassenga and others (2003), although the proportions of peat, compost, and sand were adjusted to make hydraulic properties compatible with the field conditions at seep 3-4W. Peat combined with crab compost (Chesapeake Blue), leaf compost (LeafGro), or organic dairy compost (BionSoil) facilitated reductive dechlorination of TeCA and its daughter products by WBC- 2 when mixed with wetland porewater from West Branch Canal Creek. Several other dairy-derived composts were tested but were not effective in 
enhancing degradation rates, underlining the importance of reactive material selection (Lorah and others, 2008).

In addition to the organic matrix, the incorporation of iron filings ( $-8 / 50$ mesh size) into the reactive mat was explored to facilitate abiotic dechlorination of chlorinated methanes (CT and CF), which are present in high concentrations at some seep sites and are common microbial inhibitors (Lorah and others, 2008). Rapid reductive dechlorination of the chlorinated methanes at various concentrations was observed with the addition of ZVI in batch tests (Lorah and others, 2008). Degradation of TeCA, CT, and CF also was compared in two flow-through columns that were bioaugmented with the culture-one constructed with only the organic matrix (peat-compost-sand) and one with the organic matrix overlying a zone of ZVI mixed with the organic matrix (Lorah and others, 2008). TeCA, CT, and CF and all associated daughter compounds were typically removed within half of the column length (15 in./ inches) with or without the presence of the ZVI layer, although a lower transient accumulation of methylene chloride was measured in the ZVI-organic matrix column. Rapid TeCA degradation was maintained in both column matrices when various co-contaminants, including PCE, TCE, CT, and CF were added. Complete degradation of the chloroethene and chloromethane co-contaminants and their associated daughter compounds also was observed.

\section{Design Methods and Data Analysis}

The design of the reactive mat was based on two primary objectives: (1) optimize degradation of chlorinated VOCs; and (2) maintain compatibility with the existing wetland ecosystem. Design methods and data analysis were selected on the basis of existing technologies and are presented here according to the primary objectives.

\section{Optimizing Degradation}

Results from hydrologic investigations and bench scale testing reported in Majcher and others (2007) and Lorah and others (2008) were used to conduct one-dimensional modeling of chlorinated VOC degradation through the reactive mat. BioChlor (U.S. Environmental Protection Agency, 2002) is a one-dimensional, sequential, first-order reaction rate model developed by the USEPA for screening the biodegradation of chlorinated solvent plumes in groundwater. The model was modified for chlorinated methanes and ethanes and used to predict concentrations in the field through the reactive mat. Model results were then used to estimate the overall mass removal of chlorinated ethenes, ethanes, and methanes for a given mat thickness:

$$
\left(1-\left[\sum \mathrm{CE}_{f}+\sum \mathrm{CA}_{f}+\sum \mathrm{CM}_{f}\right] /\left[\sum \mathrm{CE}_{i}+\sum \mathrm{CA}_{i}+\sum \mathrm{CM}_{i}\right]\right) \times 100=
$$

where

$$
\begin{gathered}
\sum \mathrm{CE}_{f} \text { and } \sum \mathrm{CE}_{i}=\text { the sum of final and initial mass } \\
\text { of chloroethenes, respectively; } \\
\sum \mathrm{CA}_{f} \text { and } \sum \mathrm{CA}_{i}=\text { the sum of final and initial mass } \\
\text { of chloroethanes, respectively; and } \\
\sum \mathrm{CM}_{f} \text { and } \sum \mathrm{CM}_{i}=\text { the sum of final and initial mass } \\
\text { of chloromethanes, respectively. }
\end{gathered}
$$

Maximum mass removal estimates were compared to reactive mat thicknesses that were compatible with the geotechnical, hydrologic, and water quality-conditions described in the following sections.

\section{Maintaining Compatibility with the Wetland System}

In addition to enabling a reduction in the overall mass loading of VOCs to surface water, the reactive mat was also designed to be compatible with the existing tidal wetland environment in which the seep areas were located. Geotechnical, hydraulic, and water-quality compatibility is discussed in the following sections.

\section{Geotechnical Investigations and Analysis}

Geotechnical tests were performed during the investigation phase to determine the shear strength and consolidation behaviors of the subaqueous sediments in the seep area. These tests helped predict the maximum thickness of the mat required to avoid failure of the soft contaminated sediment immediately after the mat material was placed, as well as during long-term performance. In addition, the incorporation of geosynthetic fabric into the mat design for additional strength was evaluated. Geosynthetics, which include woven or nonwoven fabrics, are used for filtration, drainage, separation, and reinforcement of soils (Koerner, 1998). Site-specific data were compared to properties of published, successful in situ subaqueous caps.

Three continuous cores were collected along the perimeter of seep area $3-4 \mathrm{~W}$ in schedule 80 polyvinylchloride (PVC) casing and sealed at both ends for laboratory analysis (Majcher and others, 2007). The standard test method for the unconsolidated-undrained (UU) triaxial compression test on cohesive soils (American Society for Testing and Materials, 2003) was performed to obtain data on the shear strength and stress-strain relationship of the native sediment. Results of the UU test were then used to perform bearing capacity calculations. The standard test method for one-dimensional consolidation properties of soils (American Society for Testing and Materials, 2001) also was performed and provided data to evaluate the magnitude of load-induced primary settlement of the wetland soil and calculate a time rate of primary settlement. A total of 17 samples from the three cores were then analyzed for Atterberg limits and water content. These 
engineering properties of the sediments allowed for an evaluation of the physical-chemical properties of the fine fraction and provided general information on minimum strength.

In addition to laboratory tests, in situ tests were performed using an electronic piezocone cone penetrometer (CPT) to obtain additional information on shear strength with depth bls. A CPT test was performed at two locations at seep $3-4 \mathrm{~W}$, the north and south ends, as described in Majcher and others (2007). A steel cone tip, a pore pressure transducer, and sensors attached to a friction sleeve were pushed into the wetland sediment using a vibracore drill on a floating platform.

As the piezocone was pushed into the sediment, tip resistance, sleeve friction, and porewater pressure were continuously recorded. These data were used to calculate bearing capacity.

The tolerable thickness of the mat was determined on the basis of geotechnical criteria of strength of the underlying sediments and the depth below grade where it was placed. The evaluation of bearing capacity was based on shallow foundation analysis for square footings in local failure (since the depth-to-width ratio is less than 4 and the length-to-width ratio is less than 5) (Das, 2002). Similar applications of empirical bearing capacity theory have been used for assessment of the tolerable thickness of in situ sand caps (Palermo and others, 1998).

The values of ultimate shear strength, $\mathrm{C}_{u^{\prime}}$, were generated from the UU laboratory tests from the three continuous cores and the in situ CPT data (average and maximum). These values of ultimate shear strength were then used to calculate ultimate bearing capacity, $\mathrm{q}_{u}$, under local (not immediate) failure conditions, according to the following empirical relation based on Terzaghi's equations (Das, 2002):

$$
\mathrm{q}_{u}=7.1 \mathrm{C}_{u}+\mathrm{q}
$$

where

$$
\begin{aligned}
\mathrm{q} & =\gamma_{s} \mathrm{D}_{f} ; \\
\gamma_{s} & =\text { unit weight of the sediment; and } \\
\mathrm{D}_{f} & =\text { depth of the mat below grade. }
\end{aligned}
$$

The allowable bearing capacity, $\mathrm{q}_{a}$, was calculated based on a conservative factor of safety (FS):

$$
\mathrm{q}_{a}=\mathrm{q}_{u} / \mathrm{FS}
$$

Finally, the tolerable thickness $T_{1}$ for this allowable bearing capacity was estimated using the method from Das (2002):

$$
\mathrm{T}_{1}<\mathrm{q}_{a} / \gamma_{r}
$$

where

$$
\gamma_{r} \quad=\text { saturated unit weight of the reactive matrix. }
$$

Whereas bearing capacity calculations address questions regarding the stability of a structure before excess porewater has dissipated from the foundation material, settlement calculations answer questions about consolidation in the long term while porewater is dissipating and the volume of the foundation is decreasing over time (Das, 2002). For clay-sized particles like those found in the mat matrix, settlement may take a long time (Das, 2002). The settlement caused by primary consolidation as well as the time to settlement was calculated with the data obtained from laboratory consolidation tests. Lab curves with incremental applied pressure loads $(\sigma)$ versus void ratio (e) were generated by the testing laboratory after the consolidation tests were performed. In geotechnical terms, the void ratio is the difference in the height of the sediment specimen before and after a load is added (Das, 2002).

Preconsolidation pressure $\left(\mathrm{P}_{c}\right.$ or $\left.\sigma_{p}{ }_{p}\right)$, or the maximum effective past pressure that the soil was subjected to, was reported with the laboratory results. Additionally, time-deformation readings were reported by the laboratory for selected samples. For each applied load, the height of the sample was plotted against time for a specified duration. From this graph, the time for which 50-percent consolidation occurred at each load is called the " $t_{50}$ " value. This value was then used in calculations to determine time to settlement.

The first step in accurately evaluating the magnitude of settlement when a given load is applied is the correction to and an evaluation of sample consolidation curves. A comparison of the initial vertical effective stress $\left(\sigma^{\prime}{ }_{v o}\right)$ was compared to the preconsolidation pressure $\left(\sigma^{\prime}{ }_{p}\right)$ to determine if the sample was overconsolidated. The initial vertical effective stress (before a load is applied) was calculated with the following equation from Coduto (1999):

$$
\sigma_{v o}^{\prime}=\gamma z-u_{o}
$$

where

$$
\begin{aligned}
\gamma \quad= & \text { bulk density of the soil; } \\
z \quad= & \text { depth of the sample; and } \\
u_{o} \quad= & \text { porewater pressure at depth } \mathrm{z}, \text { which is the } \\
& \text { pressure of the water within the soil voids. }
\end{aligned}
$$

If $\sigma^{\prime}{ }_{v o}<\sigma_{p}{ }_{p}$, then the samples are overconsolidated (Das, 2002). This means that the soil is presently not at its maximum historical stress and the pressure or stress on the soil has been relaxed over time. If $\sigma^{\prime}{ }_{v o}=\sigma_{p}^{\prime}$, the soil has been normally consolidated and the soil is experiencing its maximum stress at the time of collection (Das, 2002). If overconsolidation occurs, field virgin (corrected) consolidation curves are typically constructed from the lab curves before further calculations are made (Schmertmann, 1953).

The amount of primary settlement $\left(S_{c}\right)$ and time to primary settlement $\left(t_{\text {field }}\right)$ were the focus of further calculations. The amount of settlement due to the various anticipated 
reactive mat loads was calculated from corrected consolidation curves using adjusted void ratios (Schmertmann, 1953) to obtain a range of settlement values using the following equation from Das (2002):

$$
S_{c}=H_{\text {field }} \frac{e_{o}-e_{f}}{1+e_{o}}
$$

where

$$
\begin{aligned}
H_{\text {field }} & =\text { sediment depth over which the load is } \\
& \text { observed; } \\
e_{o} & =\text { initial void ratio; and } \\
e_{f} & =\text { void ratio at a specific applied pressure. }
\end{aligned}
$$

Both $e_{\mathrm{o}}$ and $e_{f}$ were taken from the corrected (field virgin) pressure versus void ratio curves to give a value of settlement for any specified pressure.

Calculation of $t_{\text {field }}$ depends largely on the coefficient of consolidation $\left(c_{v}\right)$. Values of $c_{v}$ were reported by the lab from the time-deformation readings for six samples (Das, 2002):

$$
c_{v}=\frac{0.197 * H_{l a b}^{2}}{t_{50}}
$$

where

$$
\begin{aligned}
& H_{\text {lab }} \quad \begin{array}{l}
=\text { height of the sediment sample used in the } \\
\text { lab test; } \text { and }
\end{array} \\
& t_{50} \quad \text { time for } 50 \text { percent of the sample to deform } \\
& \quad \text { at a specific load. }
\end{aligned}
$$

The $c_{v}$ values were then used to determine $t_{\text {field }}$ with the following equation from Das (2002):

$$
t_{\text {field }}=\frac{1.781 * H_{\text {field }}^{2}}{c_{v}}
$$

\section{Hydraulic Investigations and Analysis}

Hydraulic compatibility was investigated by comparing the hydraulic properties of the potential reactive mat materials with the native seep sediments. Hydraulic properties of the components of the reactive mat were determined in the laboratory and from previously reported values in the literature (Kassenga and others, 2003; Gillham and O'Hanessin, 1994). Flex-wall permeability tests of organic mixtures were conducted in a laboratory under 3 psi (pounds per square inch) of pressure at a specified saturated density of $78 \mathrm{lbs} / \mathrm{ft}^{3}$ (pounds per cubic foot).

A force balance was completed to assess the likelihood of fluidization of the reactive mat materials when placed in the field at the pilot test site. Using the approach outlined in
Kassenga and others (2003) for constructed wetland systems, the effective stress from the saturated weight of the reactive mat materials was compared to the stress from the upward moving porewater in the wetland sediments to ensure that the gravitational forces of the reactive mat exceeded the pore pressure in the seep area. According to Kassenga and others (2003), with an effective stress equal to zero, a critical gradient $\left(i_{c r}\right)$ can be calculated for the specific materials under a given pore pressure according to the following equation:

$$
\mathrm{i}_{\mathrm{cr}}=\left(\gamma_{\mathrm{sat}}-\gamma_{\mathrm{w}}\right) / \gamma_{\mathrm{w}}
$$

where

$$
\begin{aligned}
& \gamma_{\mathrm{sat}} \quad \begin{array}{l}
\text { saturated unit weight of the mat materials; } \\
\text { and }
\end{array} \\
& \gamma_{\mathrm{w}}=\text { unit weight of water. }
\end{aligned}
$$

\section{Geochemistry and Water Quality}

In the design phase, water-quality compatibility of the reactive mat was assessed by analyzing the potential for metal transport from the mat materials and surrounding wetland sediments. Both total metals and Sequential Extraction Procedure (SEP) analyses were performed on the reactive mat materials and wetland sediment samples to evaluate the potential release of metals into solution with geochemical changes, such as a change in the redox conditions or $\mathrm{pH}$ level. Although the mat was not designed for metals treatment, the design may alter metal solubility and may be engineered to treat metals by immobilizing them in low solubility, immobile, non-bioavailable phases.

SEP analysis separates metals in the soil into seven geochemical phases - an exchangeable phase that includes metal that is reversibly sorbed to soil minerals and six additional phases (from most to least bioavailable) that are known as carbonate, organic-bound, non-crystalline materials, metal hydroxide, acid/sulfide, and residual. These six phases quantify the amount of metal that either is irreversibly sorbed under ambient conditions, or exists as a separate mineral or immobile complex (Schultz and others, 1996; Brady and others, 2003).

SEP analyses were performed on three native wetland sediment samples from the seep 3-4W area and five organic mixes (mixes were comprised of 40/40/20 by volume compost, peat, and sand, respectively). The variable component of the mixes is the compost fraction, which included three dairy waste-derived composts (BionSoil, PayGro, and TLC), a crab-derived compost (Chesapeake Blue), and a leaf-derived compost (Leafgro). 


\section{Performance Methods and Data Analysis}

Several different methods were used to collect samples for the reactive mat pilot test, some of which were designed by project personnel to solve unique technical problems presented by the design of the mat. The following sections describe the methods used to collect and analyze samples from the site to evaluate the performance of the reactive mat between October 2004 and September 2005.

\section{Groundwater Sampling}

The groundwater sampling network was primarily within the area of seep 3-4W (figs. 1 and 5a,b; table 1) and consisted of Solinst 1.5-in.-diameter continuous multi-channel tubing (CMT) piezometers flushmounted beneath and around the perimeter of the reactive mat, drive-point piezometers installed around the entire seep area from both sides of the creek, mini-porewater samplers installed directly beneath the base of the reactive mat, and multi-level diffusion samplers set in the reactive mat.

All piezometers and most sample names begin with the letters "PT," designating that they are located at the "pilottest" area (tables 1 and 2). The name of the shallowest piezometer in a nest ends with the letter "A," while the next deeper piezometer at the same site name ends in the letter "B," and so forth.

\section{Drive-Point Piezometers}

Most drive-point piezometers (identified with the prefix PTZ) were installed to monitor only groundwater levels, although some piezometers were used for both water-quality sampling and groundwater levels. The shallow piezometers screened in the wetland sediments were installed either by pushing the casings in by hand or by using a slide hammer. Piezometers screened in the aquifer were installed using a portable vibracore drill rig mounted on floating pontoons. Most piezometers screened in the wetland sediments were constructed of 0.75 -in. and 2-in. Schedule 40 PVC, whereas the piezometers screened in the aquifer were constructed of 0.75 -in.-diameter stainless steel.

For sampling, dedicated 0.25 -in.-diameter Teflon tubing was inserted in each piezometer to the top of the screened interval. Approximately $1-\mathrm{ft}$ sections of dedicated tygon peristaltic pump tubing were attached to the top of the Teflon tubing to use in peristaltic pumps. Each piezometer was pumped slowly. Field parameters (specific conductance, $\mathrm{pH}$, and temperature) were measured at least twice, and the sample was collected after one casing volume of water was purged. This sampling technique was used to prevent drawing porewater from sediments in surrounding areas and temporarily changing flow characteristics of the seep. Some piezometers with low casing volumes or low recovery rates were sampled using dedicated $60-\mathrm{mL}$ (milliliter) syringes connected to dedicated 3 -way luer-lock valves attached to the 0.25 -in. tubing.

\section{Continuous Multi-Channel Tubing Piezometers}

CMT piezometers (identified with the prefix PTC) were installed with a portable vibracore rig. These piezometers consisted of three to six channels, each with a screened interval and sand pack approximately 6 in. long, within the same borehole. Coated bentonite pellets were placed in a protective mesh to seal the annulus space between screened intervals. A temporary outer casing of 3-in.-diameter PVC with a PVC "knock-out point" on the bottom was advanced to the top of the aquifer or base of the wetland sediments and then the 1.5-in.-diameter CMT assembly was inserted. The outer casing was immediately removed to prevent the bentonite from locking the casing in place. Expansion plugs designed specifically for the chambers were used to isolate the sample intervals.

Five of the CMT piezometers were installed within the footprint of the reactive mat prior to its construction. Immediately following sediment excavation and prior to construction of the reactive mat, the channels of each CMT were cut off below grade, and fitted with flow-through adaptors and elbows so that Teflon tubing could run horizontally underneath and beyond the reactive mat boundaries to allow for sampling. The horizontal tubing was required to avoid penetration of the two layers of geosynthetic fabric in the reactive mat. Eight additional CMT piezometers were installed around the perimeter of the mat (two on each side, fig. 5a).

As with the drive-point piezometers, dedicated 0.25 -in.diameter Teflon tubing was installed in each sample chamber to reach the top of the 3-in.-long screened interval. Dedicated tygon tubing was attached to the Teflon tubing and attached to peristaltic pumps for sample collection. Each chamber was pumped slowly, field parameters were measured, and samples were collected after one casing volume of water was purged (included the lateral tubing volume). Some CMT piezometers with low casing volumes or low recovery rates were sampled using dedicated $60-\mathrm{mL}$ syringes instead of peristaltic pumps.

\section{Mini-Porewater Samplers}

Nine mini-porewater samplers (identified with the prefix PTN, fig. 5b) were placed directly below the base of the reactive mat following sediment excavation. These samplers allowed the collection of water samples from the wetland sediments just below the bottom membrane of the reactive mat. Each sampler provided a discrete sampling point and was approximately $1 \mathrm{in.} \mathrm{long,} \mathrm{and} 0.5 \mathrm{in}$. in diameter. The sampler consisted of a 0.25 -in. screen placed inside a clean cotton bag that was filled with a clean sandpack. The screen was attached on the end of 0.25 -in.-diameter Teflon tubing. The tubing ran horizontally for the length of and slightly beyond the reactive mat boundaries to allow access for sample collection. 


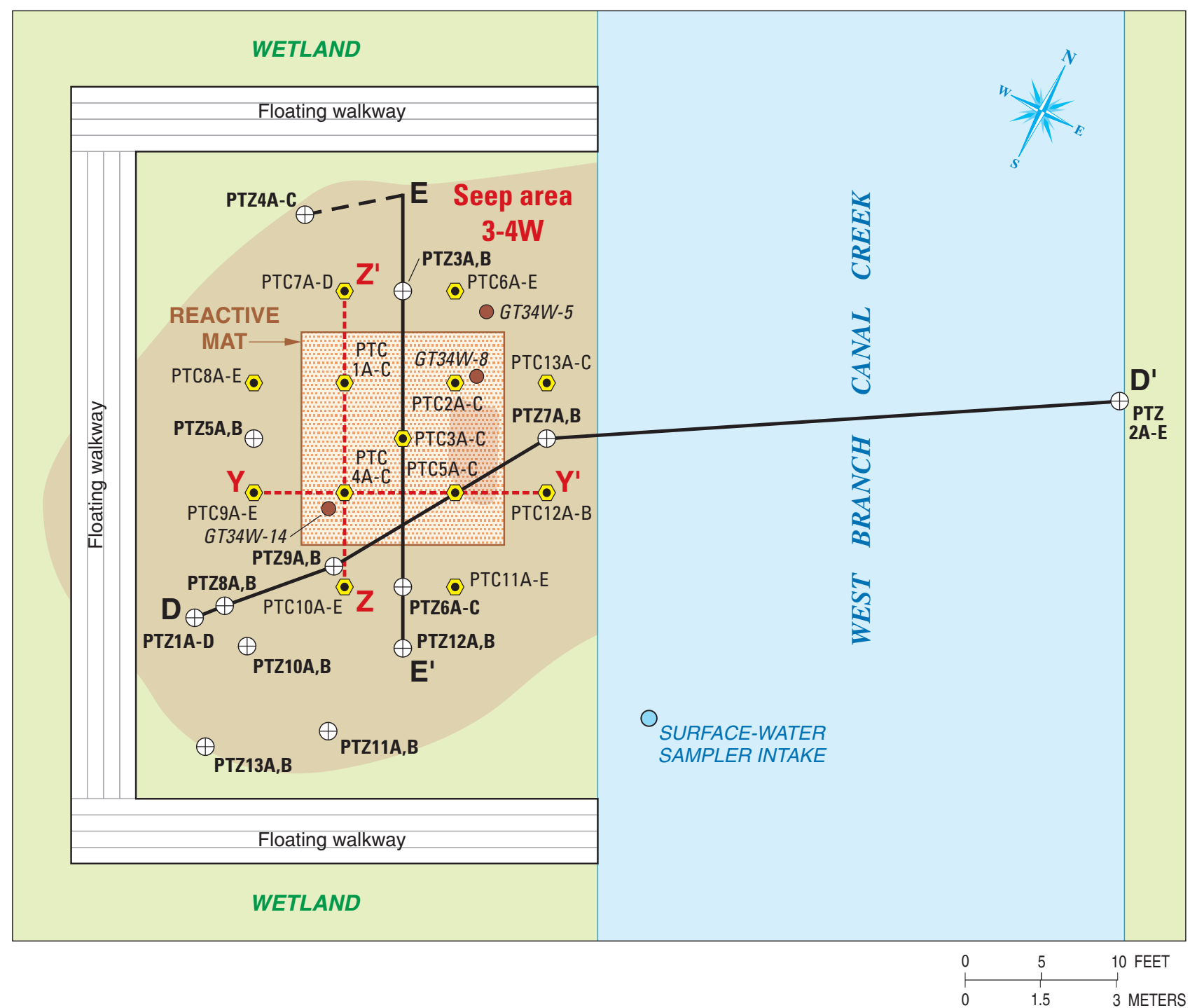

\section{EXPLANATION}

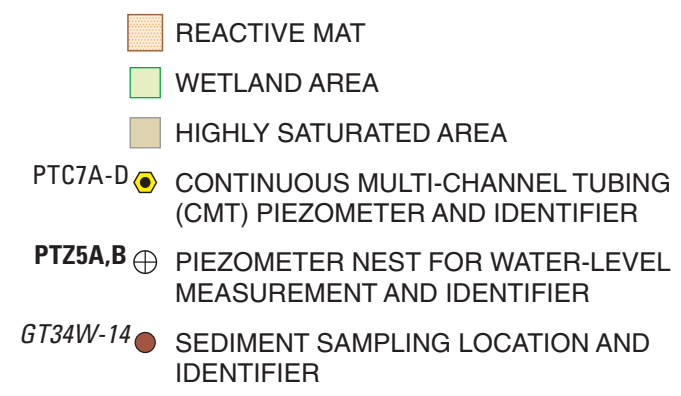

Figure 5a. Seep 3-4W piezometer network, location of reactive mat, and lines of section D-D', E-E', Y-Y', and Z-Z' at pilot-test study area, West Branch Canal Creek, Aberdeen Proving Ground, Maryland. (Refer to fig. 5b for rest of monitoring network.) 


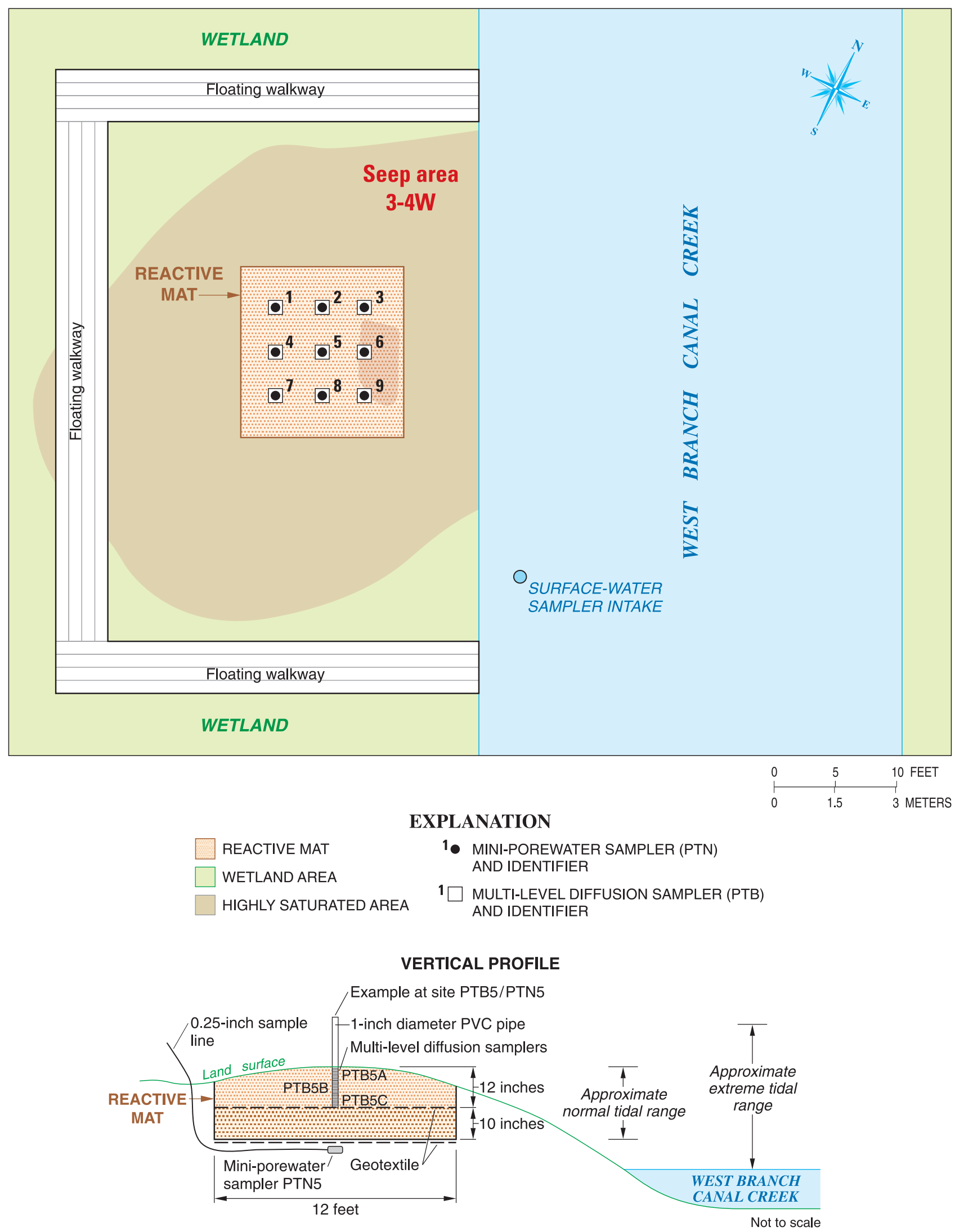

Figure 5b. Location of multi-level diffusion samplers (PTBs) and mini-porewater samplers (PTNs) at the pilot-test study area, West Branch Canal Creek, Aberdeen Proving Ground, Maryland. 
Table 1. Piezometer and sampler screen depths from the seep 3-4W reactive mat pilot test area, West Branch Canal Creek, Aberdeen Proving Ground, Maryland.

[ft bls, feet below land surface; DS, diffusion sampler, Mini, mini-porewater sampler; PVC, polyvinyl chloride; PZ, piezometer; SS, stainless steel piezometer with inner Teflon tubing; CMT, continuous multi-channel tubing; ", inch]

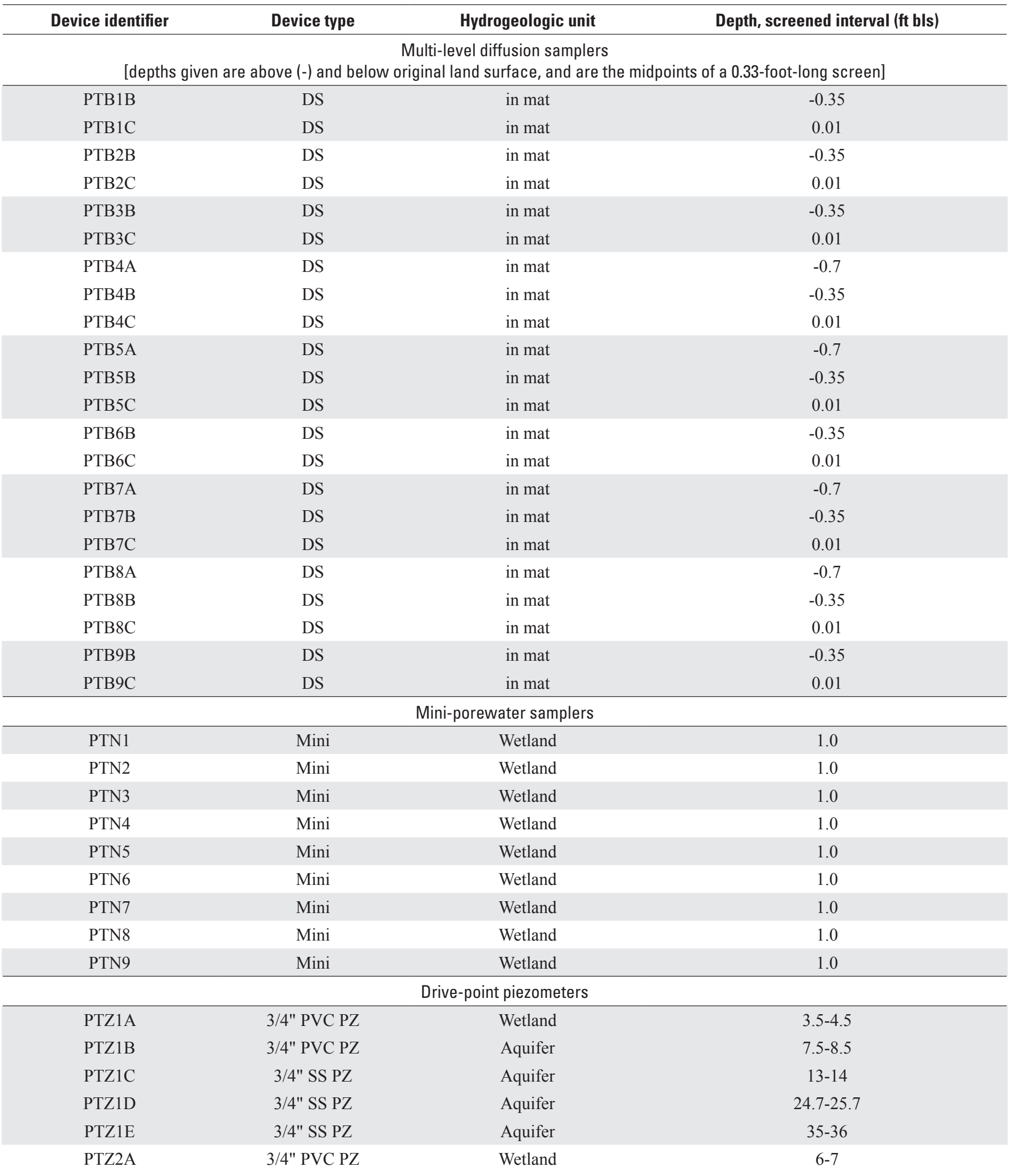


Table 1. Piezometer and sampler screen depths from the seep 3-4W reactive mat pilot test area, West Branch Canal Creek, Aberdeen Proving Ground, Maryland.-Continued

[ft bls, feet below land surface; DS, diffusion sampler, Mini, mini-porewater sampler; PVC, polyvinyl chloride; PZ, piezometer; SS, stainless steel piezometer with inner Teflon tubing; CMT, continuous multi-channel tubing; ", inch]

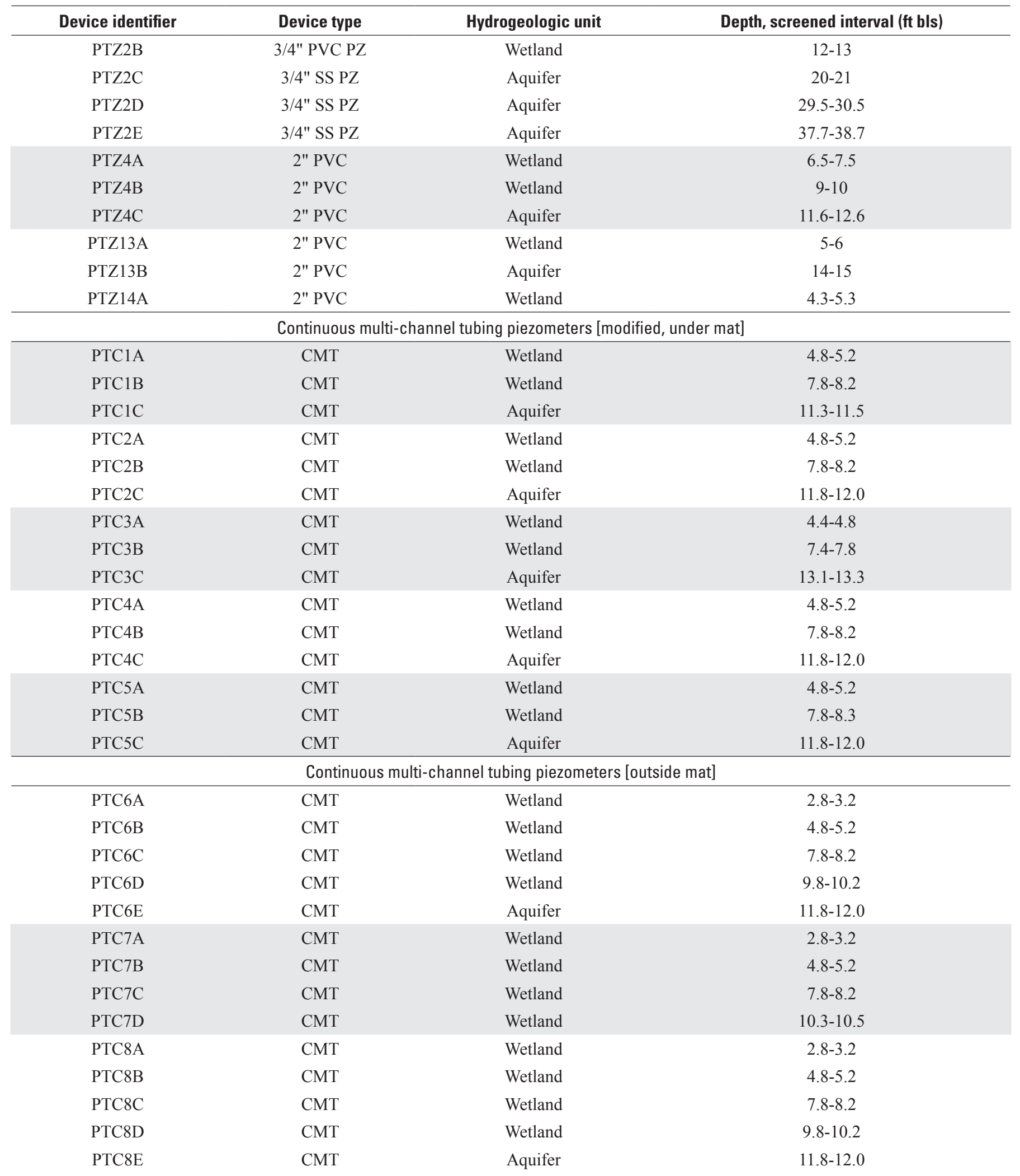


Table 1. Piezometer and sampler screen depths from the seep 3-4W reactive mat pilot test area, West Branch Canal Creek, Aberdeen Proving Ground, Maryland.-Continued

[ft bls, feet below land surface; DS, diffusion sampler, Mini, mini-porewater sampler; PVC, polyvinyl chloride; PZ, piezometer; SS, stainless steel piezometer with inner Teflon tubing; CMT, continuous multi-channel tubing; ", inch]

\begin{tabular}{lccc}
\hline Device identifier & Device type & Hydrogeologic unit & Depth, screened interval (ft bls) \\
\hline & Continuous multi-channel tubing piezometers [outside mat-Continued] & \\
\hline PTC9A & CMT & Wetland & $2.8-3.2$ \\
PTC9B & CMT & Wetland & $4.8-5.2$ \\
PTC9D & CMT & Wetland & $9.8-10.2$ \\
PTC9E & CMT & Aquifer & $12.1-12.3$ \\
PTC10A & CMT & Wetland & $2.4-2.8$ \\
PTC10B & CMT & Wetland & $4.4-4.8$ \\
PTC10C & CMT & Wetland & $7.4-7.8$ \\
PTC10D & CMT & Wetland & $9.4-9.8$ \\
PTC10E & CMT & Aquifer & $12.6-12.8$ \\
PTC11A & CMT & Wetland & $1.8-2.2$ \\
PTC11B & Wetland & $4.8-5.2$ \\
PTC11C & CMT & Wetland & $7.8-8.2$ \\
PTC11D & CMT & Wetland & $9.8-10.2$ \\
PTC11E & CMT & Wetland & $11.8-12.2$ \\
PTC11F & CMT & Aquifer & $14-14.2$ \\
PTC12A & CMT & Wetland & $2.8-3.2$ \\
PTC12B & CMT & Wetland & $4.8-5.2$ \\
PTC12C & CMT & Wetland & $7.8-8.2$ \\
PTC12D & CMT & Wetland & $9.8-10.2$ \\
PTC12E & CMT & Aquifer & $11.8-12.2$ \\
PTC12F & CMT & Aquifer & $15.2-15.4$ \\
PTC13A & CMT & Wetland & $2.8-3.2$ \\
PTC13B & CMT & Wetland & $4.8-5.2$ \\
PTC13C & CMT & Wetland & $7.8-8.2$ \\
PTC13D & CMT & Wetland & $9.8-10.2$ \\
\hline & CMT & & \\
\hline & & & \\
\hline & & & \\
\hline
\end{tabular}

Each PTN device was purged and sampled with a dedicated $60-\mathrm{mL}$ plastic syringe, fitted with a 3 -way stopcock and tubing that extended to the top of the screen. This allowed samples to be collected slowly without aerating the sample. As with the piezometers, only one casing volume (including lateral tubing volume) was removed before collecting the samples.

\section{Multi-Level Diffusion Samplers}

Multi-level diffusion samplers (identified with the prefix PTB) were constructed to characterize the in-mat porewater at up to three depths above the middle geotextile membrane. The samplers consisted of two to three 4-in.-long, 1-in.-diameter PVC screens with 0.010 -in. slots stacked together with internal plugs to isolate each screen (figs. 6a-c). The samplers were placed at nine locations within the top section of the reactive mat to the maximum depth of the geosynthetic fabric (generally up to $1 \mathrm{ft}$ deep) and directly above the locations of the PTN samplers (fig. 5b).

The number of screens in the PTB samplers was determined by the thickness of the upper section of the reactive mat. Initially, three sections of the samplers were used. The sampler locations were labeled PTB1 through PTB9, with the top section designated "A," the middle designated "B," and the bottom designated "C" (for example, PTB1C). Following initial settlement of the reactive mat, the " $\mathrm{A}$ " screen was no longer used because the sample would have been exposed to air and surface water above land surface. The remaining screens were designated " $\mathrm{B}$ " and " $\mathrm{C}$ " levels since the orientation to the middle geosynthetic fabric did not change after settlement of the reactive mat. 
Table 2. Groundwater and surface-water sampling at the seep 3-4W reactive mat pilot test area, West Branch Canal Creek, Aberdeen Proving Ground, Maryland, August 2004-September 2005.

[VOC, volatile organic compound; redox, oxidation-reduction constituents; CMT, continuous multi-channel tubing]

\begin{tabular}{|c|c|}
\hline Sample type & Sampling dates \\
\hline \multicolumn{2}{|r|}{ Groundwater samples } \\
\hline $\begin{array}{l}\text { Multi-level diffusion VOC or redox samples } \\
\text { (PTB) }\end{array}$ & $\begin{array}{l}\text { November and December } 2004 \\
\text { January, March, May, June, August, September } 2005\end{array}$ \\
\hline $\begin{array}{l}\text { Mini-porewater VOC samples } \\
\text { (PTN) }\end{array}$ & $\begin{array}{l}\text { August-September, November } 2004 \\
\text { March, May, June, August, September } 2005\end{array}$ \\
\hline $\begin{array}{l}\text { CMT and drive-point piezometer VOC samples } \\
\text { (PTC and PTZ) }\end{array}$ & $\begin{array}{l}\text { August-September, November 2004, } \\
\text { March, May, June, August, September } 2005\end{array}$ \\
\hline $\begin{array}{l}\text { CMT and drive-point piezometer inorganic samples } \\
\text { (PTC and PTZ) }\end{array}$ & $\begin{array}{l}\text { August } 2004 \\
\text { March, August } 2005\end{array}$ \\
\hline $\begin{array}{l}\text { Creek-channel passive diffusion samplers } \\
\text { (PDS) }\end{array}$ & April 2005 \\
\hline \multicolumn{2}{|r|}{ Continuous surface-water samples } \\
\hline $\begin{array}{l}\text { Inorganic samples } \\
\text { (PTV) }\end{array}$ & $\begin{array}{l}\text { 2004: August 21-22, October 25-27, December 2-3 } \\
\text { 2005: February 8-10, March 30-April 1, June 14-15, August 2-4 }\end{array}$ \\
\hline $\begin{array}{l}\text { Organic samples } \\
\text { (PTV) }\end{array}$ & $\begin{array}{l}\text { 2004: August } 25-27 \text {, October } 25-27 \text {, November } 11-12 \text {, November } 30 \text {-December } 2 \\
\text { 2005: January } 11-13 \text {, February } 8-10 \text {, March } 30-\text { April } 1 \text {, June } 14-16 \text {, August } 2-4\end{array}$ \\
\hline
\end{tabular}

Generally, the PTB samplers were first deployed with sample vials for VOC and hydrogen analysis, allowed to equilibrate for 2 weeks before sample retrieval, and then deployed again with vials for analysis of redox constituents (methane, iron, sulfide, and ammonia). Each time one set of samplers was removed, the alternate group of samplers was set in place and allowed to equilibrate until the next sampling round. For VOC and hydrogen samples, respectively, 8- and 6-mL vials were filled with deionized water and covered with porous polyethylene (secured with viton o-rings) that was previously used in passive diffusion samplers throughout the West Branch Canal Creek study area (Spencer and others, 2002). For redox constituents, a 20-mL glass vial was filled with deionized water and covered with a 0.2 -micron filter paper (HT Tuffryn) that was used previously for diffusion samplers called "peepers" (Lorah and others, 1997; Spencer and others, 2002). All samplers were submerged in deionized water for at least 24 hours, bubbled with nitrogen overnight prior to installation, and again purged for at least a half hour in the field prior to placement to displace dissolved oxygen from the sample vials.

\section{Surface-Water Sampling}

Surface-water samples for both inorganic and organic analyses were collected using automated samplers approximately monthly during the performance evaluation (table 2). An ISCO model 3700 autosampler was used to collect surface water for inorganic analyses every 4 hours for 48 hours during each sampling event. A refrigerated autosampler (ISCO model
6100) was used to collect VOC samples every 2 hours for 48 hours. Each sampler unit was staged on the floating walkways near the southeast edge of the seep area during sample collection. Intake screens for the two autosamplers were placed together along the west bank of the creek near the southeast edge of the reactive mat, where the intakes remained below the water surface under most tidal conditions (figs. 5a,b). The placement of the intake screens was designed to collect water from the creek near the discharge from the reactive mat area, and was not designed to collect samples from a representative cross section of the creek.

\section{Groundwater and Surface-Water Analysis}

Groundwater samples were analyzed for field parameters (specific conductance, $\mathrm{pH}$, and temperature), alkalinity, redox-sensitive constituents, nutrients, major inorganic constituents and trace metals, and VOCs (Appendixes 1-3). Redox constituents and nutrients analyzed for most groundwater samples included ferrous iron, methane, sulfide, ammonia, phosphate, and nitrate. Phosphate and nitrate were generally not analyzed in low-volume samples such as those collected with the PTB diffusion samplers. Unfiltered samples were collected for sulfide, ammonia, phosphate, and nitrate analysis in the field immediately after collection (Majcher and others, 2007). Methane and iron samples (0.2-micron filtered) were preserved in the field and analyzed in the USGS MarylandDelaware-D.C. Water Science Center (MD-DE-DC WSC) research laboratory (Majcher and others, 2007). Groundwater 
(A)

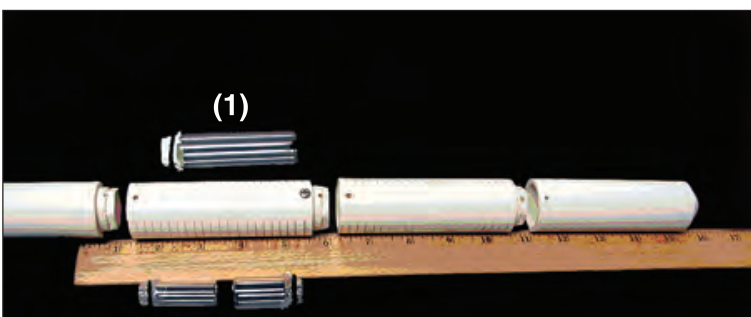

(2) (3)

Bottles for redox parameters (1), or hydrogen (2) and volatile organic compounds (3)

(B)

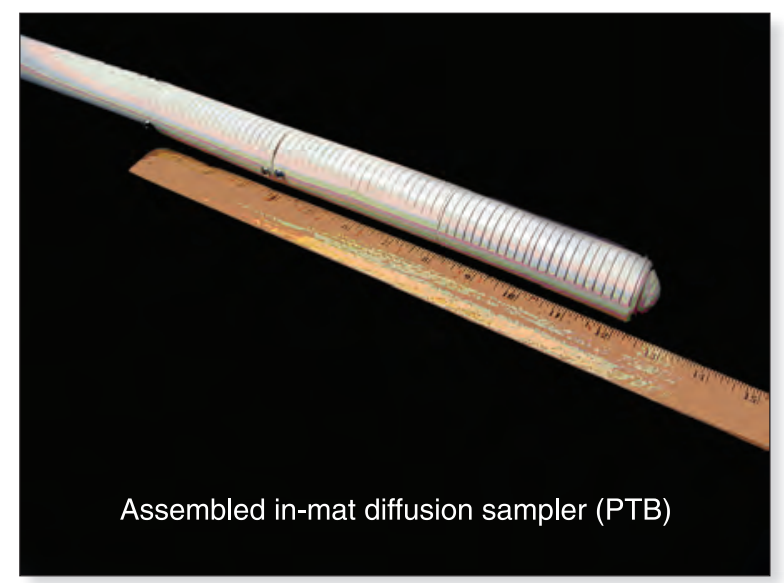

(C)

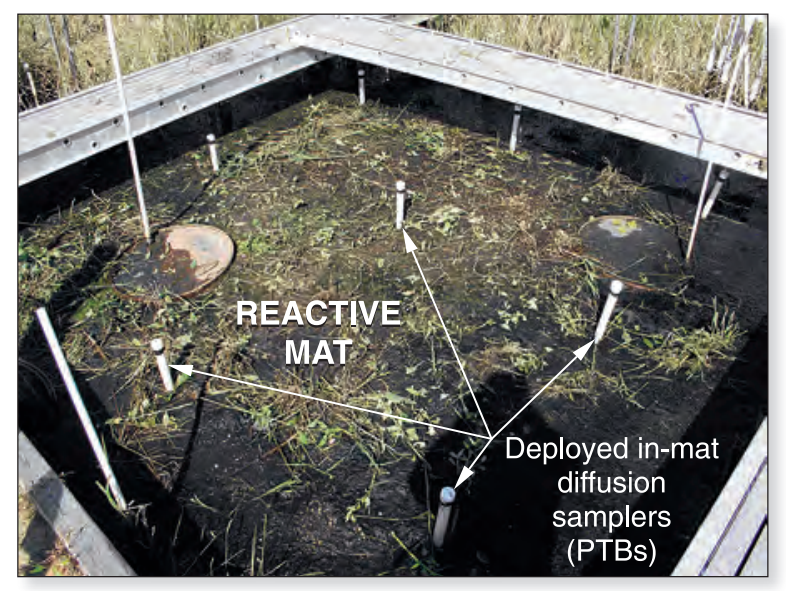

Figure 6. Multi-level diffusion samplers (PTBs) in the reactive mat $(A)$ construction, $(B)$ assembly, and $(C)$ deployment at seep 3-4W, West Branch Canal Creek, Aberdeen Proving Ground, Maryland. (Photographs by Mastin Mount, U.S. Geological Survey.) and surface-water samples also were analyzed for VOCs at the USGS MD-DE-DC WSC research laboratory using a purgeand-trap capillary gas chromatograph with a mass-selective detector (GC/MSD) (Majcher and others, 2007).

Appendix 4 gives quality-assurance data for the VOC and methane analyses conducted in the USGS MD-DE-DC WSC research laboratory.

The USGS National Water-Quality Laboratory performed the inorganic and trace metal analyses of groundwater and surface-water samples using methods detailed in Fishman (1993) and Fishman and Friedman (1989). In-mat samples were analyzed for hydrogen by SiREM Laboratory (Guelph, Ontario). Hydrogen samples were capped with Viton septa upon removal from the multi-level passive diffusion sampler and shipped on ice for analysis (Geosyntec Consultants, Inc., 2007).

\section{Reactive Mat Matrix Sampling and Analysis}

During the November 2004 and March 2005 sampling events, small samples of the reactive mat matrix were collected for microbial activity testing. A small, stainless steel scoopula was used to scrape the mat matrix from the inside wall formed by the recovery of the PTB7 multi-level diffusion sampler. These samples were placed into a nitrogen-purged 40-mL VOC vial and shipped immediately to the USGS microbiology laboratory (Reston, Virginia). Sediment samples were collected soon after installation and following the winter months to assess the viability of the dechlorinating abilities of WBC-2 in the mat matrix. WBC-2 activity was tested by placing the sediment in anaerobic culture media, amending with TeCA, and measuring its degradation along with the production and degradation of daughter products over time, as described for previous activity tests with WBC-2 (Jones and others, 2006).

\section{Determination of Hydraulic and Geotechnical Compatibility}

During the performance monitoring, the hydraulic and geotechnical compatibility of the reactive mat was assessed by observing the pilot test area for generation of new seep areas around the mat, measurement of hydraulic gradients and groundwater-flow rates, and monitoring of the settlement rate of the reactive mat. In February 2005, the USGS conducted a high resolution, low altitude (100 to $200 \mathrm{ft}$ ), aerial thermal infrared (TIR) survey of the pilot test area to compare to predeployment images from 2002-04 and determine whether seep areas were generated around the mat. Methods used during the 2002-04 flights were described in Majcher and others (2007) and were also used during 2005. Following TIR observation of the pilot test area, 30 polyethylene bag passive diffusion samplers (Vroblesky, 2001) were installed in the creek channel for one-time measurements in April 2005 to determine VOC concentrations in shallow groundwater in and around the 
pilot test area. This method was used successfully during the investigation by Majcher and others (2007) to locate areas of preferential flow.

Groundwater-level monitoring was performed using both continuous and synoptic methods to evaluate changes in hydraulic head surrounding the reactive mat. Continuous water-level data were collected using 0.375 -in.-diameter Druck pressure transducers in up to 12 piezometers (fig. 5a). Data were recorded in 1-hr (hour) intervals by Campbell Scientific CR10x data loggers. Synoptic groundwater levels were measured in up to 37 piezometers in the pilot test area (fig. 5a). Synoptic groundwater levels were collected 11 times between August 2004 and September 2005. Five of the 11 synoptic measurements included measurements on the same day at both high and low tide. Measurements were taken using steel tapes with chalk applied to the tape to indicate the water levels.

The difference in hydraulic head between shallow groundwater and surface water was measured at several locations in the seep area and within the reactive mat (at PTB5) by use of a potentiomanometer to quantify the pressure gradient between the interstitial water in the shallow sediments and the constantly changing tidal fluctuations. The instrument was used by placing one screen in the creek channel and one screen in the shallow wetland sediments or reactive mat matrix. Suction was placed on both screens to draw the water from each into a chamber where the difference between both levels could be compared. The chamber is described in detail by Winter and others (1988). Comparisons between the two levels were recorded over times ranging from 2.5 to 4.5 hours as tides were changing.

Seepage meters were deployed at up to six seep locations over multiple days at different stages of the tidal cycle.

Seepage meters were placed at various locations inside and outside the mat boundary during July-August 2005 to compare groundwater discharge rates in and around the reactive mat. Each seepage meter used during this investigation was made from the closed-end section of a 55-gallon steel drum that was inserted open-end down into the sediment, as described in Majcher and others (2007).

Seepage flux was estimated from the seepage meters by use of equation 10 :

$$
\begin{aligned}
& \mathrm{q}_{\mathrm{v}}=\mathrm{Q} / \mathrm{A} \\
& \mathrm{v}=\mathrm{q}_{\mathrm{v}} / \mathrm{n}
\end{aligned}
$$

where

$$
\begin{aligned}
& \mathrm{q}_{\mathrm{v}} \quad=\text { seepage flux (or specific discharge); } \\
& \mathrm{Q}=\text { the volume of seepage into or from the } \\
& \text { meter bag divided by the time interval; } \\
& \mathrm{A}=\text { the cross-sectional area of the meter; } \\
& \mathrm{v} \quad=\text { interstitial velocity; and } \\
& \mathrm{n} \quad=\text { effective porosity. }
\end{aligned}
$$

Seepage was considered to be positive for groundwater discharge and negative in cases where surface water flowed to groundwater.

Settlement of the reactive mat and underlying sediments was measured and compared to the settlement estimated during the design phase. The amount of settlement was determined by periodically surveying the elevation of the top of the mat at the same 111 locations along 2 diagonal (southwest to northeast, and southeast to northwest), 3 east-west, and 3 north-south transects. Elevations were surveyed on the day that the mat installation was completed on October 8, 2004, and during November 2004, and January, March, June, and July 2005.

\section{Design of a Reactive Mat for Enhanced Bioremediation}

The design of the reactive mat specific to seep $3-4 \mathrm{~W}$ is described in this section; however, the approach and application of the design procedures would generally be applicable to other groundwater/surface-water interface applications. Effects such as the influence of tidal energy and fluctuations, seasonal changes in microbial activity, and variable hydraulic discharge rates could not be simulated in the laboratory, and were tested in the field during the pilot-scale technology demonstration. Laboratory-derived design parameters related to geotechnical, hydraulic, and water-quality characteristics were verified during the field pilot test. In this section, the two major design components - consideration of degradation efficiency and wetland compatibility_ also are discussed.

\section{Degradation Efficiency}

The primary objective of the reactive mat pilot test design was to optimize degradation efficiency of the mixed chlorinated VOCs within the mat at seep 3-4W through the selection of sustainable reactive materials, electron donors, and a method for bioaugmentation with WBC-2. Degradation rates from previous laboratory investigations, including flow-through column experiments (Lorah and others, 2008; Geosyntec Consultants, Inc., 2007), were used to estimate the reactive materials thickness required to achieve a mass removal goal of at least 90 percent for total mixed chlorinated VOCs.

The reactive mat was designed with two reactive zonesa lower (hereafter referred to as ZVI-organic) zone, designed to enhance abiotic and biotic degradation of chlorinated methanes, and an upper (hereafter referred to as organic) zone, designed to enhance biodegradation of the remaining chlorinated methanes, ethanes, and ethenes. Although use of the organic matrix alone resulted in effective dechlorination in the laboratory tests, this dual-zoned approach was used in 
the mat design for seep 3-4W for several reasons. In the field, shallow porewater at the site would immediately be exposed to high concentrations of chloroemethanes (CT and CF), whereas chloroemethane concentrations were gradually increased in the column experiments for the reactive mat (Majcher and others, 2007; Lorah and others, 2008). Inclusion of ZVI also could provide a safeguard against any possible temperaturedependent rate reduction over the winter months. Therefore, the selected design for the pilot test included a lower zone comprised of a mixture of ZVI filings combined with the organic matrix. The upper zone was comprised of the organic matrix bioagumented with WBC-2 .

The selected organic matrix was a combination of commercially available compost, reed sedge peat, and sand. Of a variety of composts tested (Lorah and others, 2008), a crab compost (Chesapeake Blue) was selected for use in the pilot test at seep 3-4W because of the material's consistency and the minimal transportation cost from the nearby supplier.

On the basis of its successful use in batch tests (Geosyntec Consultants, Inc., 2007), chitin (supplied by JRW Bioremediation, Lenexa, KS) was selected as a long-term electron donor to be included in the mat materials. Commercially available irrigation drip-tubing was incorporated into the design as five laterals between the two zones of the reactive mat, through which lactate or other liquid amendments could be injected if necessary.

Because laboratory tests showed that WBC-2 had a high tolerance to oxygen exposure, direct application of WBC-2 from anaerobic culture vessels was determined to be appropriate to inoculate the reactive matrix using a standard garden sprayer hose attachment (Geosyntec Consultants, Inc., 2007). A specified volume of $24 \mathrm{~L}$ was sprayed based on a calibrated rate of application. Although previous bioaugmentation pilot tests conducted in aquifers (Ellis and others, 2000; Major and others, 2002) were used to provide some guidance for the quantity of mixed culture to add to in the field, volume adjustments were made since WBC-2 was not added to groundwater as in those demonstrations, but rather to an unsaturated, solid matrix over a wider area. The volume of WBC-2 added was 0.5 percent of the total material volume (plus a contingency volume of 20 percent), or approximately $24 \mathrm{~L}$ of culture.

On the basis of model results using input values summarized in table 3 , the mass removal of chlorinated ethenes and ethanes was predicted to be near 90 percent, with degradation occurring in both the ZVI-organic and organic zones from total reactive mat thicknesses ranging from 1 to $2 \mathrm{ft}$

(fig. 7). The mass removal of the chlorinated methanes is more difficult to predict because of multiple degradation pathways, but is estimated to be greater than 80 percent when the total thicknesses ranged from 1.5 to $2 \mathrm{ft}$. Sustained mass removal efficiency occurred for at least 8 months in the column experiments. Sustainment in the field would be correlated to methanogenic conditions in the reactive mat matrix, and the ability of WBC-2 to maintain activity under changing environmental conditions.

\section{Consideration of Compatibility With the Wetland System}

In addition to VOC mass removal, compatibility of the reactive mat with its surroundings was considered in the design. Results of investigations and design calculations for geotechnical, hydraulic, and water-quality considerations are presented in this section and are discussed relevant to the mass removal goals presented in the previous section. A summary of the site-specific design for seep 3-4W also is presented.

\section{Bearing Capacity and Settlement}

As part of the reactive mat design, geotechnical compatibility of the reactive mat with the native wetland was considered by evaluating the bearing capacity and settlement of the native sediments, and identifying criteria for a suitable geotextile to reinforce and separate the mat from the native sediments. Bearing capacity of the sediments was calculated (equation 2) for a range in saturated unit weights of the anticipated matrix materials that should yield the desired VOC mass removal. A factor of safety of three was applied to the allowable load $\left(\mathrm{q}_{\mathrm{a}}\right)$ estimate. The saturated unit weight of the native sediment was assumed to be $76 \mathrm{lbs} / \mathrm{ft}^{3}$ on the basis of physical property analysis of sediments reported in Majcher and others (2007). Tolerable thickness values for the reactive mat ranged from $0.93 \mathrm{ft}$ to $5.3 \mathrm{ft}$ (table 4), based on a 60/40 ZVI-organic/ organic zone ratio, by volume. In these calculations, equal thicknesses were assumed for the ZVI-organic and organic zone. The minimum tolerable thickness values $(0.93,1.60 \mathrm{ft})$ were estimated using a $\mathrm{C}_{u}$ from the uppermost zone of both CPT locations within seep 3-4W. The thickness of the mat based on VOC mass removal goals exceeded the lower end of the minimum thickness range. To minimize bearing capacity issues and the height of the mat above the original land surface, some excavation of surface sediments was incorporated into the design.

Field- and laboratory-determined shear strength results and other physical properties from West Branch Canal Creek sediments were compared to published results of installed, in situ sand caps on soft sediments (table 5). Physical properties of the West Branch Canal Creek sediments (such as Atterberg limits and water content) were within the range of other reported sediments on which in situ sand caps were placed, although the undrained shear strength values at West Branch Canal Creek are in the upper range of those reported for sediments elsewhere (table 5). The resulting tolerable thickness values calculated for the Canal Creek sediments are within the range of those reported as successful in situ caps.

Load-induced primary settlement and time to settlement of native sediments underlying the proposed reactive mat area within seep area 3-4W were calculated from results of laboratory one-dimensional consolidation tests. Samples from cores at seep 3-4W revealed that $\sigma^{{ }^{\prime}}{ }_{v o}<\sigma_{p}{ }_{p}$ (after $\sigma^{\prime}{ }_{v o}$ was calculated from equation 5) indicating that samples were 


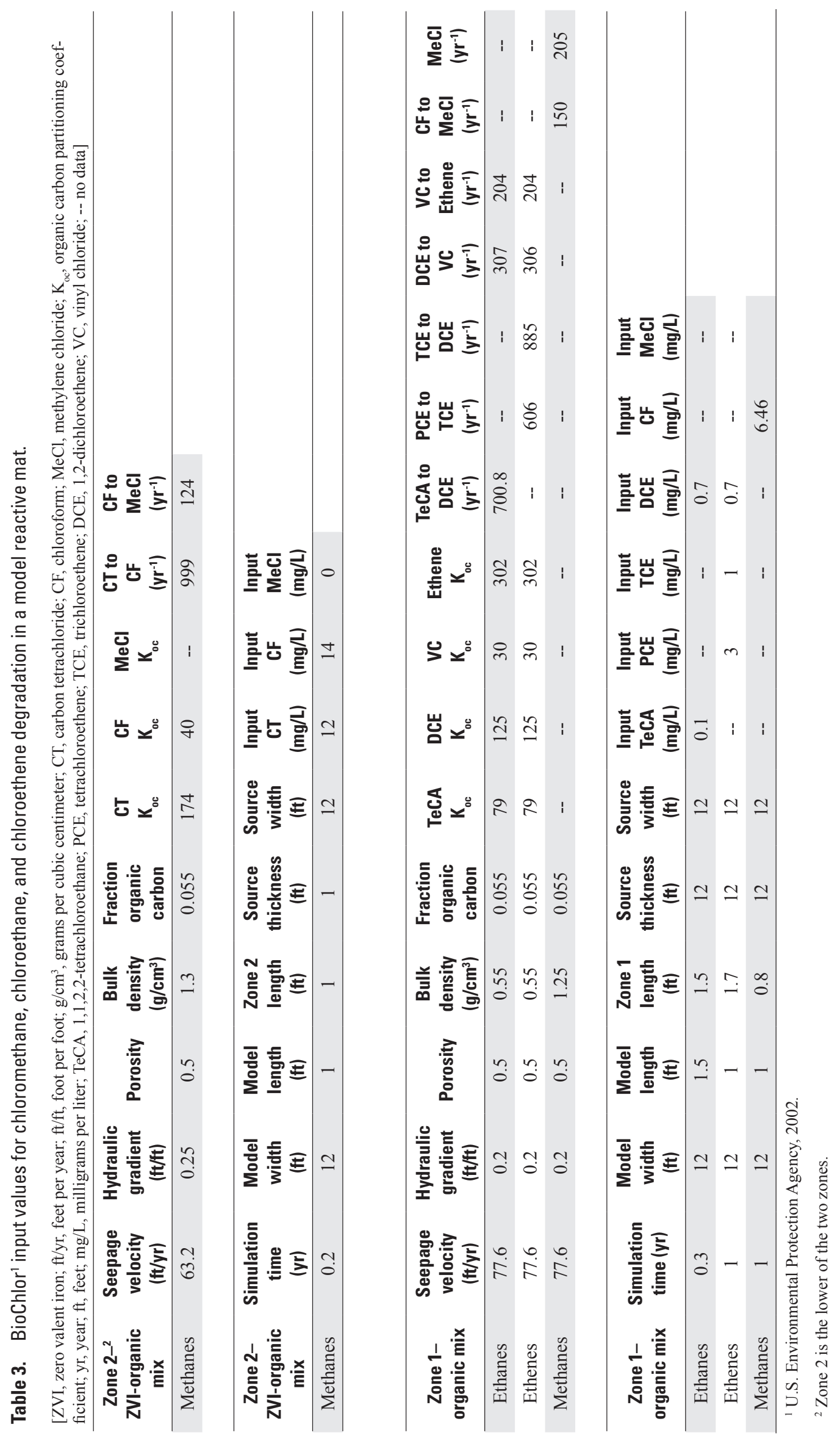


(A)

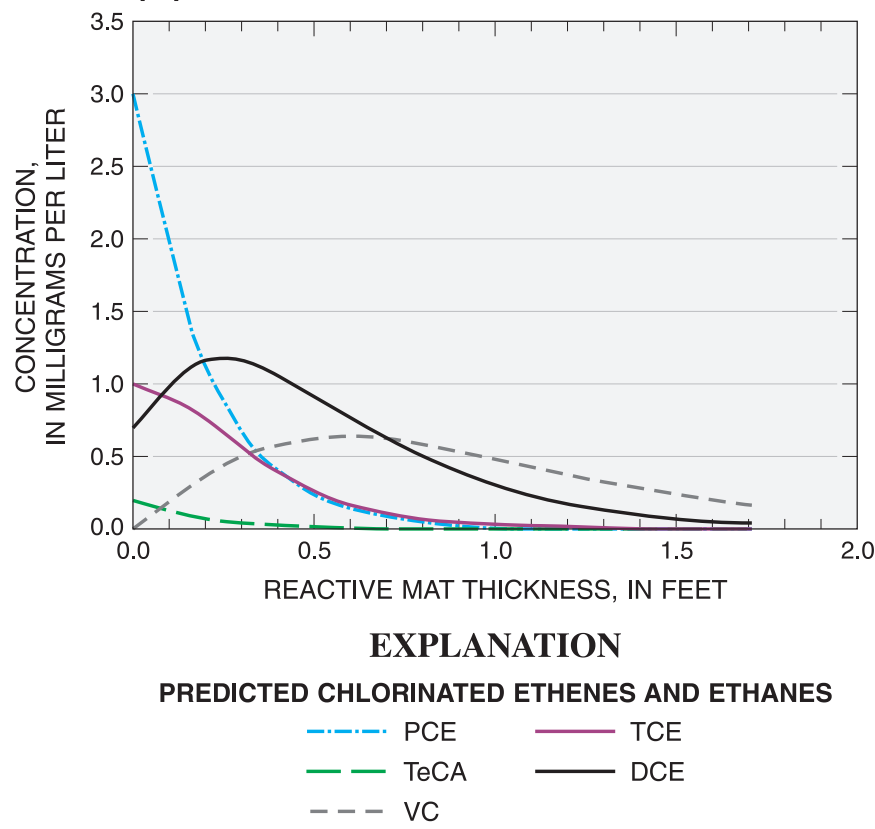

(B)

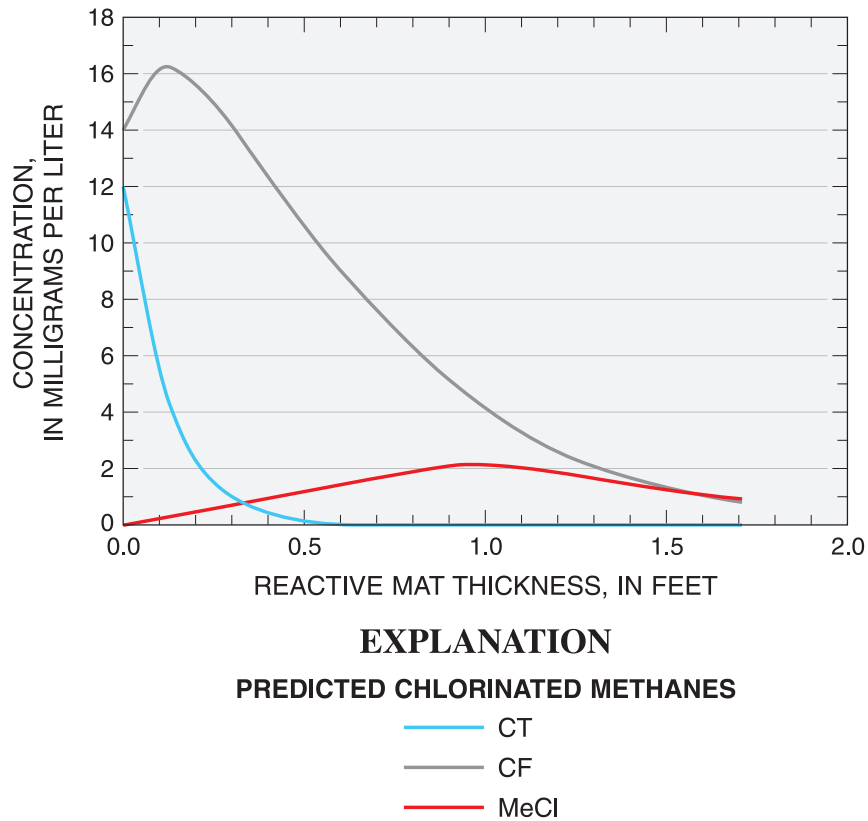

Figure 7. Concentrations of major chlorinated volatile organic compounds predicted by BioChlor (U.S. Environmental Protection Agency, 2002) in a simulated reactive mat $(A)$ chlorinated ethenes and ethanes [tetrachloroethene (PCE), trichloroethene (TCE), 1,1,2,2-tetrachloroethane (TeCA), 1,2-dichloroethene (DCE), and vinyl chloride (VC)], and (B) chlorinated methanes [carbon tetrachloride (CT), chloroform (CF), and methylene chloride (MeCl)].

overconsolidated. On the basis of these results, field virgin (or corrected) consolidation curves were constructed for the overconsolidated sediment and used for subsequent calculations.

The magnitude of settlement was calculated from the laboratory odeometer tests based on load intervals equal to twice the reactive mat load (factor of safety of 2) determined in the bearing capacity calculations and a thickness range of 2 to $3 \mathrm{ft}$. Since percent total organic carbon in the wetland sediments was negatively correlated with depth bls (Majcher and others, 2007), two representative one-dimensional consolidation test results from different depths were used for the settlement calculations. The field virgin curves (developed on the basis of overconsolidation of sediments) consistently gave lower values of settlement ranging from 0.12 to $0.37 \mathrm{ft}$ (equation 6). Calculations using the lab curve predicted settlement of 0.97 to $1.4 \mathrm{ft}$.

A range in time of primary settlement was calculated by estimating an appropriate coefficient of consolidation $\left(c_{v}\right)$ using laboratory and empirical methods. The range of $c_{v}$ values estimated by the laboratory from time-deformation readings at loads greater than the anticipated load from the reactive mat was 0.01 to $0.03 \mathrm{ft}^{2} / \mathrm{d}$ (square feet per day). These laboratory estimates of $c_{v}$ were compared to values determined from empirical relations between $c_{\mathrm{v}}$ and liquid limit (Naval Facilities Engineering Command, 1986) and $c_{v}$ and organic silt (Holtz and Kovacs, 1981), respectively, which give $c_{v}$ values ranging from 0.016 to $0.017 \mathrm{ft}^{2} / \mathrm{d}$ and 0.018 to $0.088 \mathrm{ft}^{2} / \mathrm{d}$. Using the median $c_{v}$ value of $0.017 \mathrm{ft}^{2} / \mathrm{d}$ and equation 8 , the calculated time for settlement was 1.5 years within the upper $5 \mathrm{ft}$ of wetland sediment.

In order to provide filtration, separate the native sediment from the two reactive zones, and account for an overestimate of shear strength, a geotextile material was included at the base of the reactive mat (fig. 8). Hydraulic properties considered in filtration design were porosity (ratio of void volume to total fabric volume), apparent opening size (AOS) or the sieve size restricted by the fabric, and cross-plane permeability (flow through the fabric). The porosity and permeability of the geotextile needed to be greater than the porosity of the native sediment and the reactive matrices to avoid any impediment to flow. More than 50 percent of the site sediment passed through the No. 200 sieve, and since the wetland sediment is predominantly clay and silt, a No. 70 AOS was selected (Koerner, 1998), combined with a fabric porosity greater than the porosity of the native sediment (estimated to be 0.4 based on the void ratio). Finally, to prevent any impediment of the seepage flow, the permeability of the fabric was selected to be greater than the maximum vertical hydraulic conductivity at seep 3-4W, which was calculated to be $0.34 \mathrm{ft} / \mathrm{d}$, or feet per day $\left(1.2 \times 10^{-4} \mathrm{~cm} / \mathrm{s}\right.$, or centimeters per second) (Majcher and others, 2007). The sediment and matrix properties indicated that the selection of a nonwoven, polypropylene geotextile (GSE Inc., Houston, TX) was adequate for the site-specific application (see following Hydraulic Design section). When installed, the nonwoven geotextile material was keyed into the surrounding sediment to anchor it in place during installation. 
Table 4. Calculated reactive mat tolerable thicknesses based on laboratory and field-determined unconfined shear strength of wetland sediments at seep 3-4W, West Branch Canal Creek, Aberdeen Proving Ground, Maryland.

[CPT, cone penetrometer; $\mathrm{C}_{\mathrm{u}}$, unconfined shear strength; $\mathrm{D}_{\mathrm{f}}$, foundation depth below land surface; $\gamma$, unit weight; $\mathrm{q}_{\mathrm{u}}$, ultimate bearing capacity; $\mathrm{q}_{\mathrm{a}}$, allowable bearing capacity; $1 \mathrm{bs} / \mathrm{ft}^{2}$, pounds per square foot; $\mathrm{ft}$, feet; $1 \mathrm{bs} / \mathrm{ft}^{3}$, pounds per cubic foot]

\begin{tabular}{|c|c|c|c|c|c|c|c|c|}
\hline Location & $\underset{\left(\mathrm{Ibs} / \mathrm{ft}^{2}\right)}{\mathrm{C}_{\mathrm{u}}}$ & $\begin{array}{l}D_{f} \\
\text { (ft) }\end{array}$ & $\begin{array}{c}\text { Sediment } \gamma \\
\left(\mathrm{lbs} / \mathrm{ft}^{3}\right)\end{array}$ & $\underset{\left(I b s / f t^{2}\right)}{q_{u}}$ & $\begin{array}{c}\text { Factor of } \\
\text { safety }\end{array}$ & $\underset{\left(\mathrm{lbs} / \mathrm{ft}^{2}\right)}{\mathrm{q}_{\mathrm{a}}}$ & $\begin{array}{c}\text { Reactive } \\
\text { Mat } \gamma \\
\left.\text { (lbs/ft }{ }^{3}\right)\end{array}$ & $\begin{array}{c}\text { Tolerable } \\
\text { thickness } \\
\text { (ft) }\end{array}$ \\
\hline $\begin{array}{l}\text { North core - } \\
\text { Laboratory }\end{array}$ & 140 & 1 & 76 & 768 & 3 & 256 & 98 & 2.61 \\
\hline $\begin{array}{l}\text { South core - } \\
\text { Laboratory }\end{array}$ & 300 & 1 & 76 & 1,558 & 3 & 519 & 98 & 5.30 \\
\hline $\begin{array}{c}\text { North CPT, } \\
\text { minimum }\end{array}$ & 40 & 1 & 76 & 274 & 3 & 91 & 98 & 0.93 \\
\hline $\begin{array}{l}\text { South CPT, } \\
\text { average }\end{array}$ & 200 & 1 & 76 & 1,064 & 3 & 355 & 98 & 3.62 \\
\hline
\end{tabular}

Table 5. Sediment properties from reported successful in situ capping projects and wetland sediments at seep 3-4W, West Branch Canal Creek, Aberdeen Proving Ground, Maryland.

[LL, liquid limit; PI, plasticity index; lbs/ft ${ }^{2}$, pounds per square foot; \%, percent, CPT, cone penetrometer; >, greater than; <, less than; NR, not reported; ND, not determined; NA, not applicable; APG, Aberdeen Proving Ground]

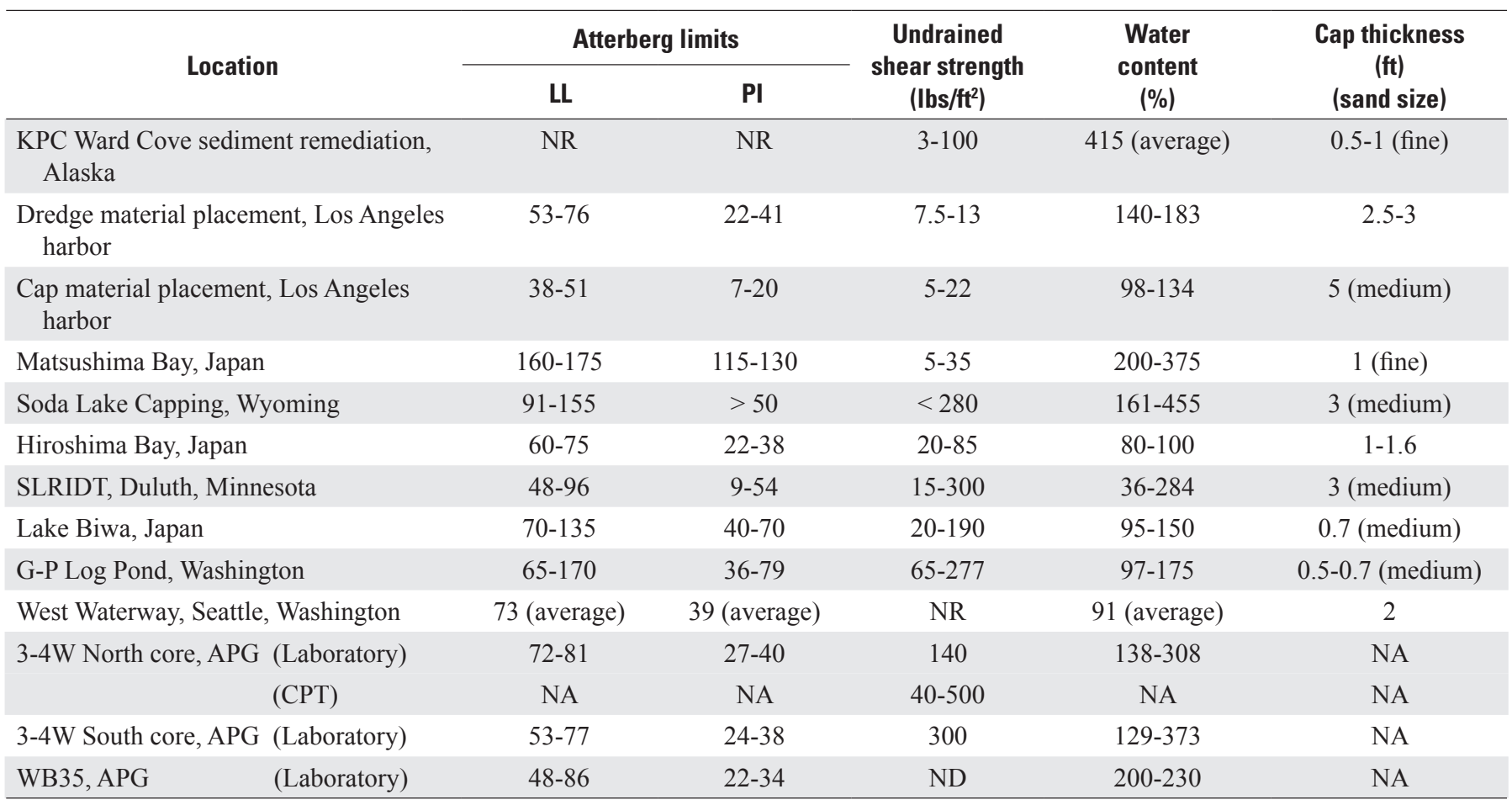

(modified from Palermo and others, 1998) 


\section{Hydraulic Design}

Hydraulic properties of the components of the reactive matrix were measured in the laboratory permeability tests and from previously reported values in the literature; conductivity values of a similar compost-peat-sand mixture ranged from 0.37 to $0.85 \mathrm{ft} / \mathrm{d}\left(1.3 \times 10^{-4}\right.$ to $\left.3 \times 10^{-4} \mathrm{~cm} / \mathrm{s}\right)$ at a saturated density of $78 \mathrm{lbs} / \mathrm{ft}^{3}\left(1.25 \mathrm{~g} / \mathrm{cm}^{3}\right.$, or grams per cubic centimeter $)$ (Kassenga and others, 2003). Similarly, laboratory results from two composts were near the range reported in the literature ( 0.57 to $1.13 \mathrm{ft} / \mathrm{d})$. Given this range of vertical conductivity values, an average organic matrix vertical hydraulic conductivity of $0.57 \mathrm{ft} / \mathrm{d}\left(2 \times 10^{-4} \mathrm{~cm} / \mathrm{s}\right)$ was conservatively estimated. The conductivity of a 100-percent ZVI zone using the $-8 / 50$ mesh size was estimated to be $1,700 \mathrm{ft} / \mathrm{d}(0.6 \mathrm{~cm} / \mathrm{s})$, using particle size data analysis (Majcher and others, 2007). In combination with the 40/40/20 organic mixture, hydraulic conductivity increased when compared to the mixture alone, even at a low volumetric proportion (such as 20 percent), as confirmed with laboratory estimates. In general, at a saturated density greater than that of water, $62 \mathrm{lbs} / \mathrm{ft}^{3}$, all materials used in the reactive mat matrix have a hydraulic conductivity greater than the surrounding sediments reported previously for the seep area (Majcher and others, 2007).

A force balance was completed to assess the likelihood of fluidization of the reactive mat materials when placed in the field, under artesian conditions at the seep site. Using the approach outlined in Kassenga and others (2003) for constructed wetland systems, the effective stress from the saturated weight of the reactive mat materials was compared to the stress from the upward moving porewater in the wetland sediments. From this pressure balance, a critical gradient and resulting critical flow were estimated above which fluidization of the reactive mat materials may occur. Due to the high saturated density of the ZVI zone, only the organic mixture zone was used to assess fluidization. The calculated critical gradient

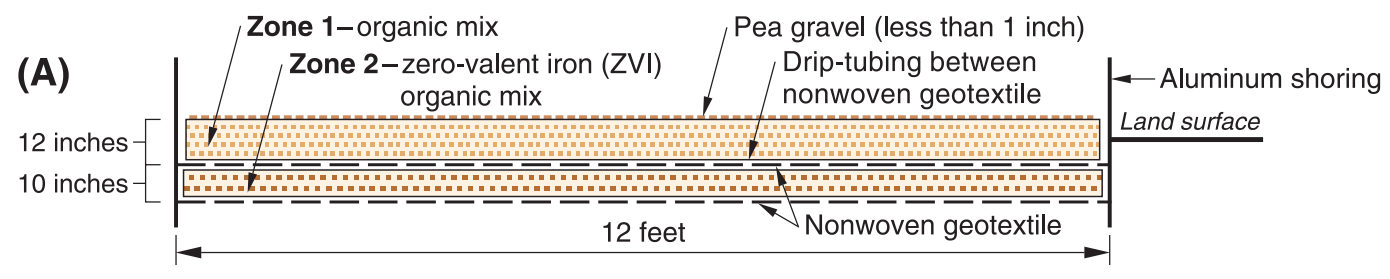

(B)

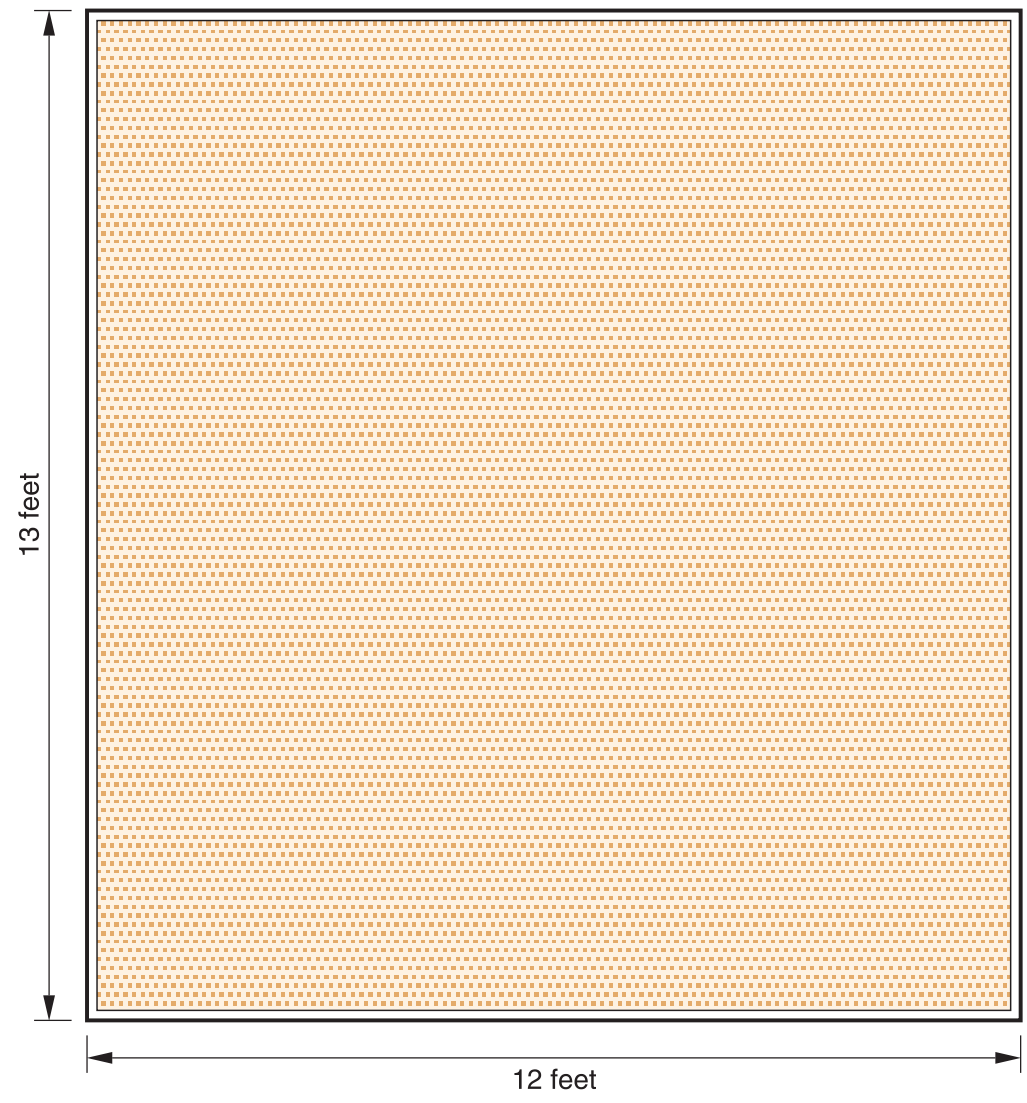

Figure 8. Reactive mat schematic for seep 3-4W, West Branch Canal Creek, Aberdeen Proving Ground, Maryland $(A)$ cross-sectional view, and $(B)$ plan view. 
of $0.3 \mathrm{ft} / \mathrm{ft}$ (feet per foot) was in the range of the maximum vertical hydraulic gradients measured at seep 3-4W. Using the average vertical hydraulic conductivity of the organic mix, the critical flow $(0.18 \mathrm{ft} / \mathrm{d})$ was estimated near the measured maximum seepage velocity (Majcher and others, 2007). Therefore, using a factor of safety of 2 , with the measured seepage velocity from the site equal to the critical flow, an optimized saturated density of materials was estimated. A mixture of 1.5 parts compost, 1.5 parts peat, and 1 part sand (37.5/37.5/25 by volume) achieved the required increase in saturated density.

This optimized mixture was conservative in that it assumed all seepage velocity in the pilot test area exceeded the critical flow of the materials. Majcher and others (2007), however, reported that seepage actually varied spatially within the boundaries of the pilot test area and therefore, only the maximum was used in the fluidization estimate. The high transmissivity (or inter-planar flow) of the nonwoven geotextile that was selected for installation between the ZVI zone and the organic zone was expected to normalize flow conditions in the treatment area. For ease of installation, the same nonwoven geotextile material selected for the base filtration was used.

The strong, vertical hydraulic gradients and increased vertical hydraulic conductivity in the seep sediments at $3-4 \mathrm{~W}$ result in artesian conditions at the pilot test area. The hydraulic gradient (or overall change in head) in the regional area is a result of the recharge in the upland area (pressure head) and overall elevation differences between the uplands and the wetlands (elevation head) as described by Bernoulli's equation. At seep 3-4W, this gradient is strongly upward (Majcher and others, 2007). The addition of materials to a maximum of $10 \mathrm{in}$. above the current wetland surface elevation is a minimal change in the overall regional flowpath and is only an addition of approximately 5 percent of the overall thickness to the local wetland sediments; therefore, this addition was not anticipated to impact the gradient. On the local scale, the static water level height (pressure head) in piezometers screened in the wetland and aquifer sediments along the perimeter of the pilot test area was 1 to $3 \mathrm{ft}$ above the baseline wetland surface elevation. These pressure heads appeared to be adequate to maintain upward flow through the reactive mat.

Given the estimated hydraulic properties of the reactive mat matrix materials and the hydraulic gradient at the site, a hydraulic residence time (HRT) within the reactive mat was estimated for various reactive mat thicknesses, hydraulic gradients, and effective porosities. A higher hydraulic conductivity than that of natural sediments combined with the natural vertical gradient would promote flow into the porespace of the reactive zones of the reactive mat, according to Darcy's Law. For a 22 -in.-thick reactive mat, with an effective porosity between 0.4 and 0.6 and a vertical hydraulic gradient of 0.3 , the HRT within the reactive mat was predicted to range from approximately 8 to 14 days, assuming a predominantly vertical flowpath. Therefore, a sampling frequency of every 2 weeks was used to provide adequate time for a pore volume exchange through the reactive mat.

\section{Geochemistry and Water Quality}

Although the overall objective of the reactive mat was to reduce mass loading of chlorinated VOCs to surface water from seeps, it was critical that actions taken to remediate the VOCs did not create a secondary water-quality problem due to soluble metals or nutrients. Changing redox conditions and $\mathrm{pH}$ have been shown to mobilize metals in some in situ bioremediation applications in aquifers. In addition, nutrient runoff into surface water can cause negative water-quality effects, including depressed dissolved oxygen and increased submerged aquatic vegetation. Due to the sensitive nature of wetlands, care was taken to evaluate the potential to mobilize both metals and nutrients from the reactive mat materials prior to placement in the wetland. Existing soil criteria, which are based on human health and drinking-water standards for unsaturated sediment, are not applicable to assess the impact of the placement of materials into wetlands. Therefore, alternate sediment criteria were selected to evaluate the use of the reactive mat matrix materials in a freshwater environment, and evaluate the potential to mobilize any contaminants during sediment excavation. MacDonald and others (2000) developed consensus-based sediment-quality guidelines (SQGs) to be used as predictors of sediment-quality conditions in freshwater systems, and these were used for reference in the design of the reactive mat. The probable effect concentrations (PECs) derived by MacDonald and others (2000) are levels above which adverse biological effects are expected to occur. These values, developed from data across North America, can predict adverse effects on a regional basis (Ingersoll and others, 2000). The predictive ability of the consensus-based PEC values can be used to assess the potential effects of contaminated sediment on sediment-dwelling organisms (Ingersoll and others, 2000; Ingersoll and MacDonald, 2002), and were used as a screening tool for native sediment and the reactive mat materials.

Total metals concentrations in the three native sediment samples showed that arsenic, lead, mercury, nickel, and zinc concentrations were greater than consensus-based PECs for these metals (table 6). Subsequent SEP analyses indicated that these metals were bound mostly in the organic, carbonate, non-crystalline, or metal hydroxide fractions (Appendixes 5A,B). The low $\mathrm{pH}$ present at the site and the desire to decrease the redox potential from iron-reducing to methanogenic conditions has the potential to increase the solubility of those metals bound in the carbonate and hydroxide fractions; however, the metals bound to the organic and non-crystalline fractions were considered fairly stable in the sediment.

Metals for which PECs do not exist were also qualitatively assessed for current and future levels in the wetland sediment and porewater. Aluminum, iron, manganese, and nickel were detected in elevated concentrations in sediment, but were primarily bound tightly in the residual phase (Appendixes 5A,B). The less dominant, metal hydroxide bound fraction of iron and manganese may become more 
mobile under more highly reduced redox conditions. Zinc, which is predominantly found in the non-crystalline and residual fractions, also was found with concentrations in the more loosely bound metal hydroxide and carbonate fractions.

SQG-derived PECs also were used to assess the metals detected in a variety of composts, including those derived from dairy, leaf, and crab wastes. Copper concentrations in the three dairy-derived compost samples were greater than those in the consensus-based PECs. Copper was bound mostly in the organic fraction for each dairy compost sample and therefore was not readily available. Copper sulfate is used at dairy farms to prevent foot disease in cattle, which may explain its detection in all three compost samples. The two alternative composts were not dairy farm-derived and did not contain copper above the PEC.

The results of the Chesapeake Blue and Leafgro analysis showed concentrations that ranged from one-half to one order of magnitude below the consensus-based PECs for all eight metals. The remaining metals have been compared to the SEP results of the three native sediment samples, which were viewed as background concentrations (Appendixes 5C-E). With the exception of calcium (Chesapeake Blue and Leafgro) and manganese (Leafgro only), all of the remaining metals were found in concentrations less than or equal to concentrations found in the native sediment. Calcium concentrations in Chesapeake Blue and Leafgro were one-half to one order of magnitude greater than values found at one native sediment sampling location (GT34W-5), and greater than one order of magnitude at the two remaining native sediment sampling locations (GT34W-8, GT34W-14; fig. 5a). The Chesapeake Blue compost has calcium bound in the exchangeable, organic, carbonate, and metal hydroxide fractions. For the Leafgro compost, the majority of the calcium was bound in the exchangeable and organic fractions. The presence of calcium in the exchangeable phase may indicate an expected increase in nearby surface-water concentrations of calcium. Currently, no Maryland or Federal surface-water criteria for calcium exist.

Organic compost products are frequently used as a source of nutrients to soils. Therefore, their use in the reactive mat could increase loading of nutrients to West Branch Canal Creek. The nutrient (nitrogen and phosphorus) content of native sediments at the pilot test site was compared to reported nutrient content in the composts (table 7). The phosphorus content of the compost mixtures was an order of magnitude greater than that measured in the native sediments, but nitrogen was within the range of the nitrogen content for sediment. In laboratory column tests conducted with the mat materials, an increase in soluble nitrogen and phosphate was detected (Lorah and others, 2008). It is difficult to predict the behavior of these nutrients in the field, their ultimate fate in the environment, and their impact on surface water, since laboratory tests do not take into account nutrient cycling that will occur in the natural environment. These results indicate that periodic nutrient monitoring (ammonia, nitrate-nitrite, and phosphate) of the reactive mat porewater and the nearby surface water was needed to evaluate their potential impacts.

\section{Reactive Mat Design Summary for Seep 3-4W}

The area selected for placement of the reactive mat at seep 3-4W was flat, and more than $10 \mathrm{ft}$ from the west bank of West Branch Canal Creek (figs. 5a,b). The mat encompassed a $12-\mathrm{ft}$ by $13-\mathrm{ft}$ area that had the maximum discharge and VOC concentrations at the seep (Majcher and others, 2007). The overall tolerable thickness of the two zones, including the geotextile materials, was approximately $2 \mathrm{ft}$ with safety factors included; however, the ZVI-organic zone was limited to a maximum of $10 \mathrm{in}$. and the subsequent organic zone was limited to a maximum of $12 \mathrm{in}$. at the mat center for a total maximum thickness of $22 \mathrm{in}$. The reactive mat was placed $1 \mathrm{ft}$ below grade to minimize stability concerns. Although the reactive mat would initially extend above the natural wetland surface, it was estimated that the final topography of the seep area would be closer to the original topography after predicted settlement.

The ZVI-organic zone was comprised of ZVI filings (aggregate-size $-8+50$, Peerless Metal Powders \& Abrasives, Detroit, MI) and the organic mixture. This organic mixture consisted of 1.5/1.5/1/0.25 parts compost (Chesapeake Blue, Cambridge, MD), peat (New Plant Life, Newbury, IN), \#1 drilling sand (Toney Drilling, Baltimore, MD), and chitin (JRW Bioremediation, Lenexa, KS). The ZVI and organic materials were combined in a variable volume ratio ranging from 60 to 40 percent ZVI and 40 to 60 percent organic mixture (fig. 8a), with a part of the northeast quadrant of the reactive mat consisting of 15 percent ZVI and 85 percent organic mixture. The upper reactive zone was comprised entirely of the organic mixture in a consistent volumetric ratio of 1.5 parts compost, 1.5 parts peat-chitin mixture, and 1 part sand (fig. 8a). The reactive mat was covered with a fine layer of pea gravel to anchor fines during initial settling and possible storm events.

At the base of the reactive mat and between the ZVIorganic and organic zones, a recycled, nonwoven geotextile was placed to facilitate filtration, normalize flow, and provide a safety factor for bearing capacity. Between the two reactive zones, separated by the non-woven geotextile, a delivery system consisting of small diameter, commercially available irrigation tubing was installed to deliver soluble electron donor or, if rebioaugmentation was required, WBC-2 culture (fig. 8). The delivery system was comprised of 5 laterals of $10-\mathrm{ft}$, 0.25 -in. (outer diameter) polyethylene tubing with built-in emitters spaced 6 in. apart along each lateral (Dripworks, Willets, CA).

Following site preparation (fig. 9a) and sediment excavation (fig. 9b), the reactive mat was constructed in shallow, $2 \mathrm{ft}^{3}$ lifts (fig. 9c) until it reached the desired thickness. The organic zone was bioaugmented with WBC-2, as shown in figure 9d. A total of $24 \mathrm{~L}$ of the mixed culture, WBC-2, was added in liquid to the reactive mat. All VOCs were purged from the culture media before the culture was applied to the reactive matrix. 


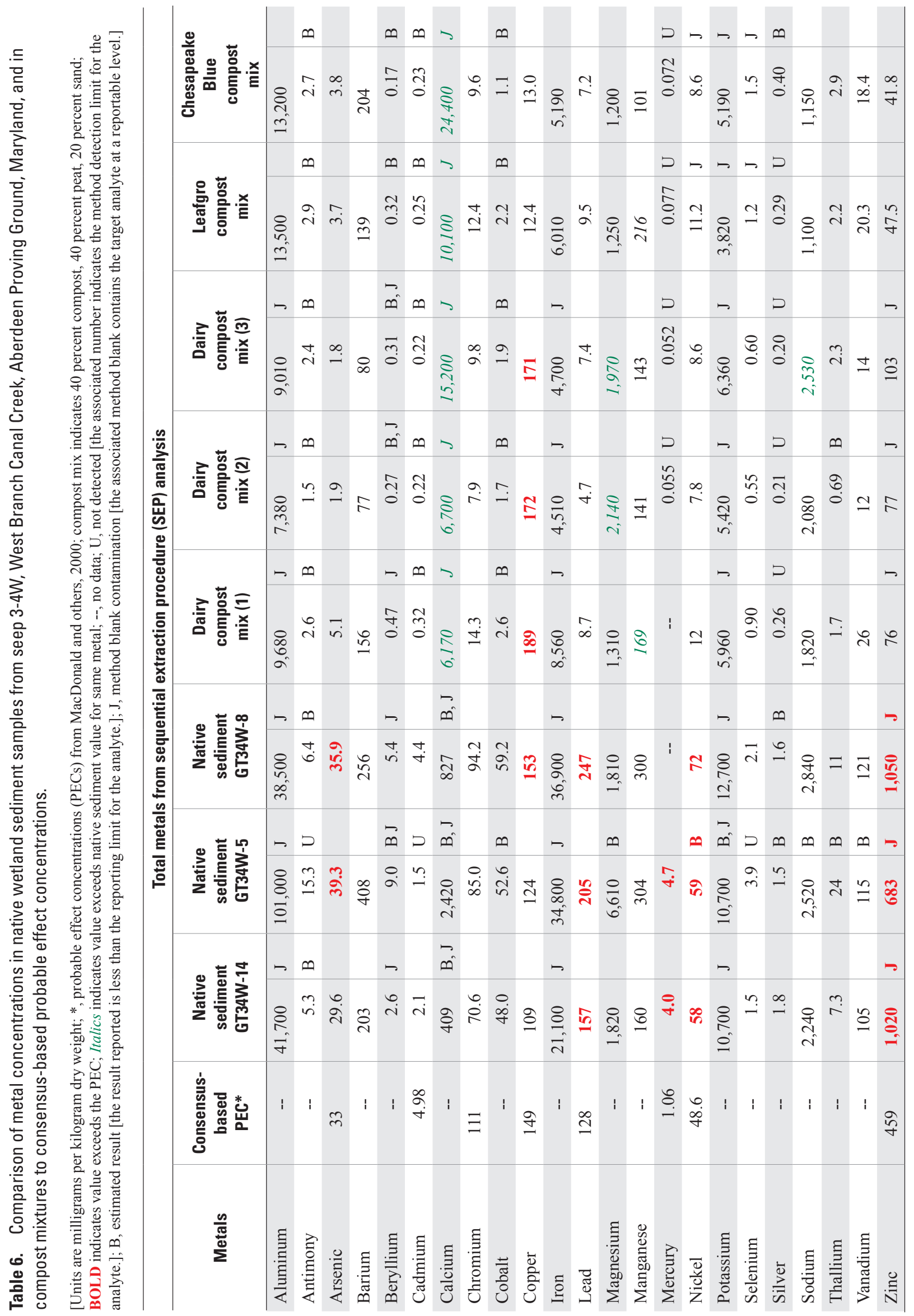


Table 7. Nutrient and organic matter content of composts used in this study.

$[\%$, percent; mg/kg, milligrams per kilogram; BET, Bion Environmental Technologies, Inc.; MES, Maryland Environmental Services; NR, not reported; <, less than].

\begin{tabular}{|c|c|c|c|c|}
\hline $\begin{array}{l}\text { Nutrients and } \\
\text { organic matter }\end{array}$ & $\begin{array}{l}\text { Units } \\
\text { (dry) }\end{array}$ & $\begin{array}{c}\text { BET } \\
\text { BionSoil } \\
\text { organic } \\
\text { dairy }\end{array}$ & $\begin{array}{c}\text { New Earth } \\
\text { Chesapeake } \\
\text { Blue crab }\end{array}$ & $\begin{array}{c}\text { MES } \\
\text { Leafgro } \\
\text { leaf }\end{array}$ \\
\hline Total Nitrogen (N) & $\%$ & 1 & 0.66 & 1.5 \\
\hline $\mathrm{NH}_{4}$-Nitrogen & $\mathrm{mg} / \mathrm{kg}$ & NR & $<100$ & 175 \\
\hline $\mathrm{NO}_{3}-\mathrm{NO}_{2}$ Nitrogen & $\mathrm{mg} / \mathrm{kg}$ & NR & 184 & NR \\
\hline $\mathrm{NO}_{3}$-Nitrogen & $\mathrm{mg} / \mathrm{kg}$ & NR & NR & 41 \\
\hline Organic Nitrogen & $\%$ & NR & 0.66 & 1.5 \\
\hline Phosphorus (P) & $\%$ & 0.5 & 0.82 & NR \\
\hline Phosphorus $\left(\mathrm{P}_{2} \mathrm{O}_{5}\right)$ & $\%$ & NR & NR & 0.53 \\
\hline \multirow[t]{2}{*}{ Potassium (K) } & $\%$ & 0.5 & 0.03 & NR \\
\hline & $\mathrm{mg} / \mathrm{kg}$ & NR & NR & 6,837 \\
\hline Potassium $\left(\mathrm{K}_{2} \mathrm{O}\right)$ & $\%$ & NR & NR & 0.82 \\
\hline Organic Matter & $\%$ & 40 & NR & 51 \\
\hline Carbon:Nitrogen & ratio & NR & 12 & 18 \\
\hline
\end{tabular}

\section{Performance of a Reactive Mat Pilot Test for Enhanced Bioremediation}

After measurement of baseline conditions in August and September 2004, and installation of the reactive mat in October 2004 at seep area 3-4W, monitoring was conducted through October 2005 to evaluate the performance of the pilot test to determine whether the design objectives outlined in the previous sections were met. Seep 3-4W represented a highly contaminated seep area with mixed chlorinated ethenes, ethanes, and methanes. A successful pilot test would demonstrate a new remedial solution for mixed, chlorinated VOCs near the groundwater/surface-water interface.

\section{Pre-Installation Conditions}

On the basis of results from PDSs, peepers, seepage meters, and CPT data at seep 3-4W (Majcher and others, 2007), the reactive mat was placed over the area with the greatest concentrations of parent chlorinated VOCs and the greatest point of discharge to surface water for the primary contaminants within the seep area, including CT, CF (fig. 10a shows CF distribution; CT distribution was similar to CF), and PCE (fig. 10b). It was known that the placement did not encompass all of the contaminated part of the seep area, especially the pre-existing chlorinated daughter compounds, such as $c i s-1,2-\mathrm{DCE}$ (fig. 10c). Vertical profiles of VOC distribution within this area indicated that mass increased with decreasing depth bls (fig. 11), and that porewater was largely in ironreducing conditions, with no detections of methane (Majcher and others, 2007).

After multi-level monitoring points were installed below and surrounding the seep area in August 2004, a broader and more defined areal and vertical baseline of VOC distribution and hydrologic behavior could be assessed. Total VOC concentrations at the top of the Canal Creek aquifer (depth of $12 \mathrm{ft}$ ) were greatest at PTC4C, and extended laterally beyond the proposed southern boundary of the mat footprint (fig. 12a). At $5 \mathrm{ft}$ bls within the wetland sediments, concentrations in the southwestern boundary were approximately the same as at the top of the aquifer, but an additional hotspot was apparent at PTC6, an area to the northeast of the mat boundary in the wetland sediments (fig. 12b) near a previous peeper sampling location and an area of high seepage (Majcher and others, 2007). This distribution is consistent with PDS results and indicates an expansion of the overall VOC distribution near land surface. Although an order of magnitude less, the chlorinated ethenes and ethanes also were found in the highest concentrations along the southern boundary area and followed a similar pattern with decreasing depths. More than 99 percent of the total measured VOC mass was comprised of parent compounds (CT, CF, PCE, TCE, TeCA, hexachloroethane, and pentachloroethane), with no apparent degradation in the vertical profile from the aquifer to land surface. Methane was not detected (less than $2 \mu \mathrm{M}$, or micromolar) in this area, except at a few isolated locations where it was detected below the threshold concentration for methanogenic conditions (Appendix 1, table 8).

Regional hydrologic characterization of the area indicated that groundwater discharges in a generally vertical direction from the underlying aquifer toward the central area of the wetlands from the west and east (Lorah and others, 1997; Lorah, Spencer, and McGinty, 2005; Phelan and others, 2002; Weston Solutions, 2005; General Physics Corporation, 2005). In the area of seep 3-4W, discharge was focused on the western boundary of the creek channel at very discrete points (Majcher and others, 2007). Along line of section D-D' (fig. 5a) that spans the creek channel from west to east and bisects the mat location, upward groundwater discharge in this localized area was evident in the low and high tide potentiometric surfaces (figs. 13a,b). The seep boundaries were not apparent. The pre-installation potentiometric surface along a north to south line of section E-E' (fig. 14) was consistent with the west to east section, indicative of vertical flow at both low and high tides (fig. 14). The planar potentiometric surface in the wetland sediments 3 to $5 \mathrm{ft}$ bls that was obtained with the finescale monitoring network at the pilot test area showed gradual flow towards the creek, which was slightly greater at low tide when water levels are mainly contained within the creek channel (fig. 15). The magnitude of change in the potentiometric surface (gradient) was substantially lower in the horizontal direction compared to the vertical direction. Vertical hydraulic 
(A)

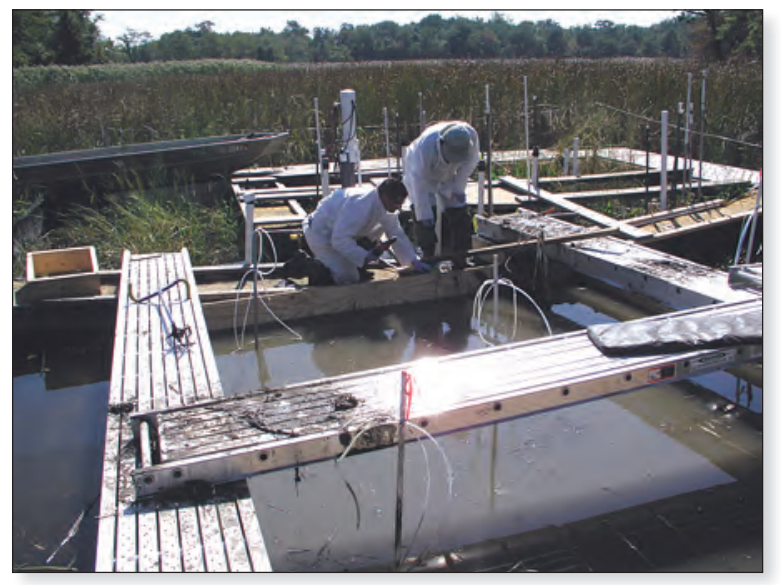

(C)

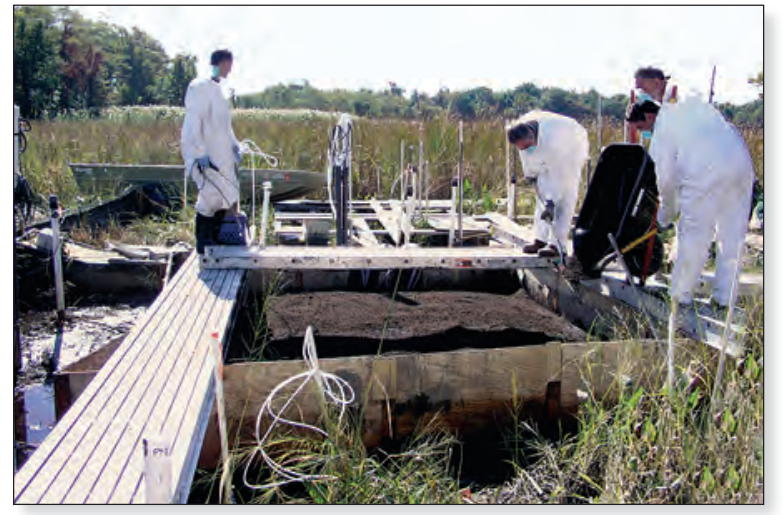

(B)

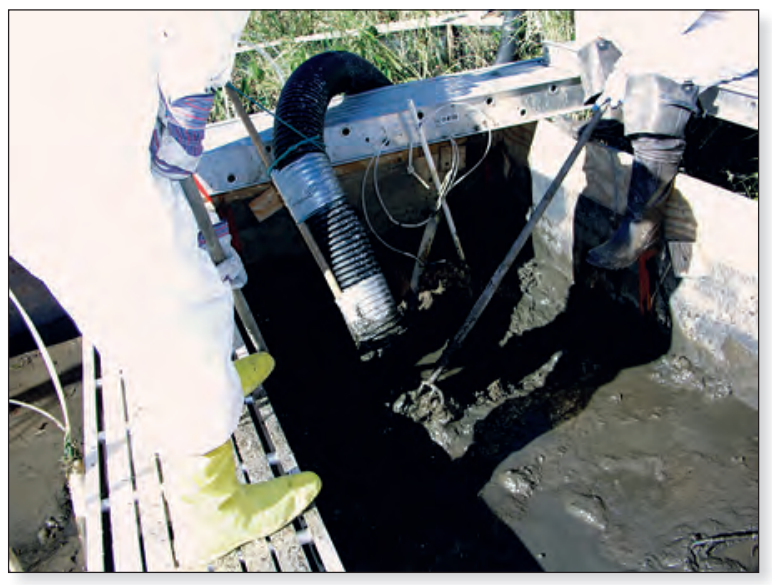

(D)

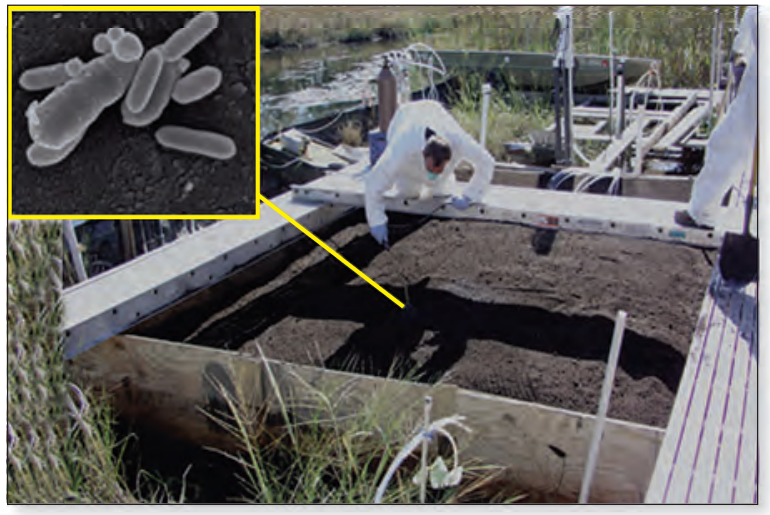

Figure 9. Installation of a reactive mat pilot test at seep 3-4W, West Branch Canal Creek, Aberdeen Proving Ground, Maryland, $(A)$ site preparation, $(B)$ sediment excavation, $(C)$ reactive material placement, and $(D)$ bioaugmentation with WBC-2. (Photographs by Michelle Lorah, U.S. Geological Survey.)

gradients from the underlying aquifer into the overlying wetland sediments in the pilot test area were consistent at low and high tides, ranging from 0.12 to 0.25 across the area. These gradients are consistent with or slightly lower than vertical gradients reported in Majcher and others (2007) for the seep area, and Lorah, Spencer, and McGinty (2005) in the wetland study area, and are at least an order of magnitude greater than horizontal gradients in the area.

The baseline distributions of chlorinated VOCs are shown in two dimensions along west-east (Y-Y') and southnorth (Z-Z') cross sections through the southern and western edges of the reactive mat, respectively (fig. 5a; figs. 16, 17). Isoconcentrations of chloromethanes indicate that the greatest mass of these contaminants was immediately below the southwest corner of the mat location, near the top of the aquifer sediments (12 ft bls) (figs. 16a, 17a). Therefore, some contamination appeared to extend beyond the western boundary of the mat toward PTC9 and to the east towards
PTC12 in the upper parts of the wetland sediments (fig. 16a). Along the south-north cross section on the western plane of the reactive mat location, maximum contamination was centered at PTC4, and contaminants appeared to extend beyond the mat boundary to the south (fig. 17a). Chlorinated ethenes and ethanes follow similar patterns as the chlorinated methanes, spreading in a lateral direction with decreasing depths bls along the two sections (figs. 16b, 17b). Cross sections along the eastern and northern planes (data not shown) indicated a secondary hotspot (also evident in the planar distribution in figs. 10 and 12b) that extended beyond the northeast boundary of the mat, and was not adequately captured within the mat footprint. Although contaminant distribution exceeded the proposed mat boundaries, consistent contaminant transport primarily in the vertical direction from the aquifer through the upper wetland sediments provided sufficient opportunity to show effectiveness of the reactive mat within the placement area. 

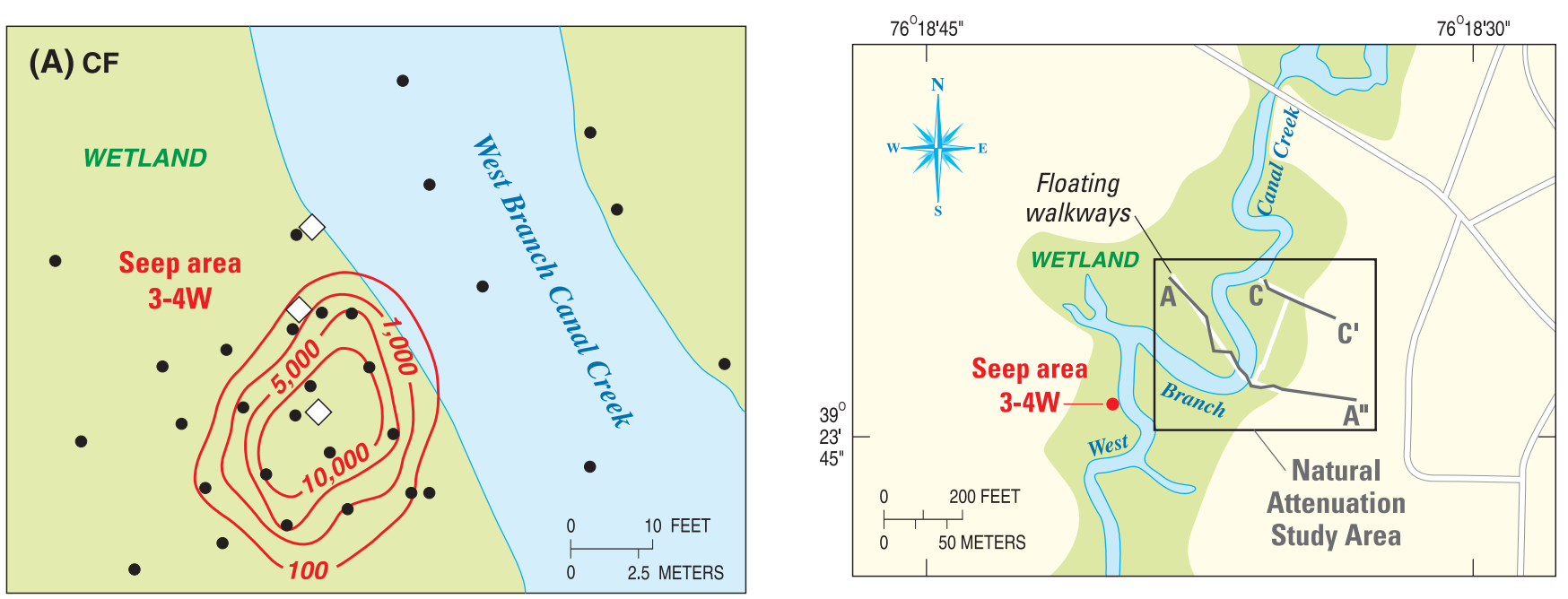

Location of seep area $3-4 \mathrm{~W}$.
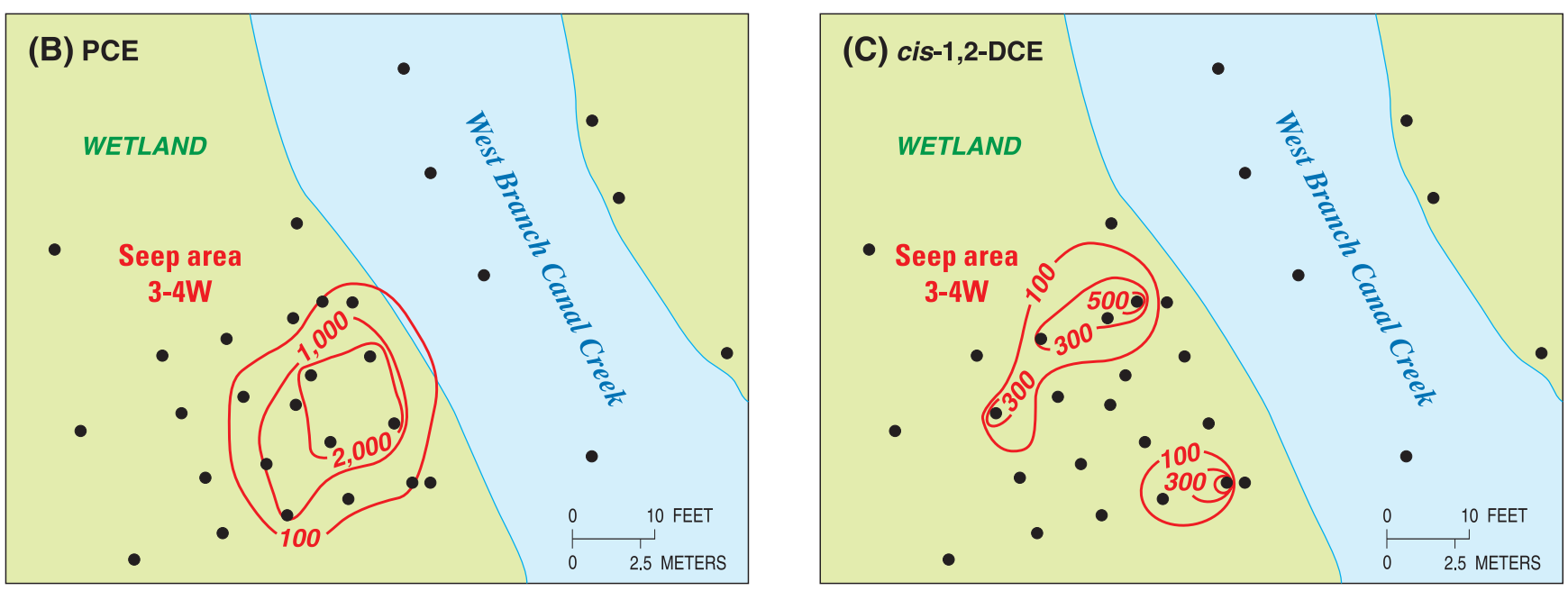

\section{EXPLANATION}

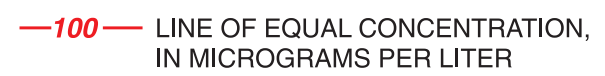

- PASSIVE-DIFFUSION SAMPLER $\quad \diamond$ PEEPER LOCATION
LOCATION

Figure 10. Distribution of selected volatile organic compounds in shallow porewater, seep location 3-4W, April (DS163-DS176) and December (DS317-DS332) 2003 in relation to the reactive mat pilot test, West Branch Canal Creek, Aberdeen Proving Ground, Maryland, $(A)$ chloroform (CF), (B) tetrachloroethene (PCE), and (C) cis-1,2-dichloroethene (cis-1,2-DCE) (modified from Majcher and others, 2007).

\section{Assessment of Volatile Organic Compound Degradation}

Degradation of chlorinated VOCs by WBC-2 requires anaerobic conditions in the subsurface. In this section, the establishment of conditions favorable for anaerobic degradation of these contaminants is discussed. The distribution and removal of VOCs were assessed to evaluate the degradation efficiency of the reactive mat pilot test at seep 3-4W.

\section{Establishment of Conditions Favorable for Anaerobic Degradation}

Throughout the monitoring period, the mat was evaluated for conditions that would facilitate anaerobic degradation (primarily biodegradation) of chlorinated VOCs. Redoxsensitive constituents (ammonia, iron, sulfide, methane), hydrogen, and WBC-2 activity were analyzed to evaluate a change from iron-reducing to methanogenic conditions that 


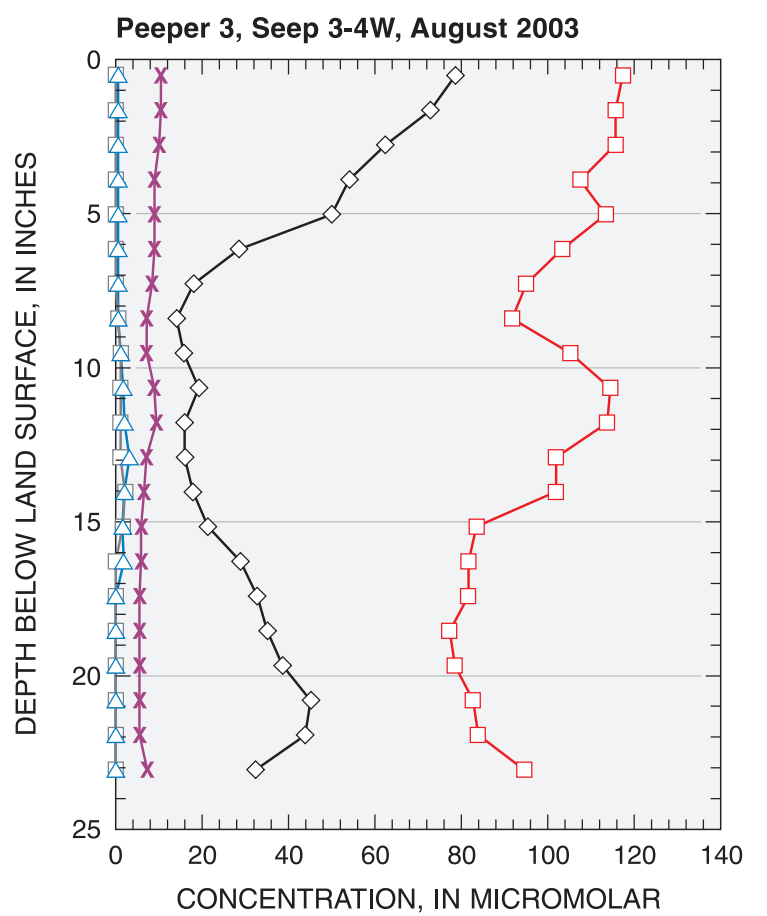

EXPLANATION

$\diamond \backsim$ CT (carbon tetrachloride)
$\square \square \mathrm{CF}$ (chloroform)
$\longleftarrow \mathrm{X} \mathrm{PCE} \mathrm{(tetrachloroethene)}$
$\square \triangle \mathrm{MeCl}$ (methylene chloride)
$\square-\square \mathrm{TCE}$ (trichloroethene)

Figure 11. Vertical distribution of selected chlorinated volatile organic compunds at seep location 3-4W, West Branch Canal Creek, Aberdeen Proving Ground, Maryland, August 2003 (modified from Majcher and others, 2007).

are favored by WBC-2 (Jones and others, 2006; Lorah and others, 2008). Consistent with results from previous investigations, the amount of methane in samples proved to be the most valuable indicator for appropriate conditions (Lorah, Spencer, and McGinty, 2005; Lorah and others, 2008). Methane could be used alone (or in combination with iron) in future applications for a more streamlined analytical program to evaluate mat redox conditions.

Ammonia concentrations measured in the reactive mat over the monitoring period were greater than ammonia concentrations in underlying and surrounding native sediment (Appendix 1). Increased ammonia concentrations were likely due to the nitrogen introduced with the compost contained in the reactive mat. Maximum concentrations of ammonia were detected in May 2005 (15 mg/L, or milligrams per liter; or $0.8 \mathrm{mM}$, or millimolar). Ammonia concentrations decreased in July $(5.5 \mathrm{mg} / \mathrm{L}$ or $0.31 \mathrm{mM})$ and August 2005 (less than
$0.7 \mathrm{mg} / \mathrm{L}$ or $0.04 \mathrm{mM}$ ). A subsequent increase was measured in September 2005, which resulted in a more evenly distributed concentration from 5 to $8 \mathrm{mg} / \mathrm{L}(0.3$ to $0.4 \mathrm{mM})$. These fluctuations may be attributed to the invasion and growth of non-native vegetation in the reactive mat during the summer months, followed by removal of plant biomass in early September 2005. Ammonia concentrations did not correlate well with the other redox constituents, and the presence of ammonia did not appear to have an adverse effect on the production of methane. The presence of ammonia also may be indicative of favorable conditions for the degradation of chlorinated methanes, which can occur under denitrifying conditions (Bouwer and McCarty, 1983).

Soluble ferrous iron and sulfide were both detected in minimal concentrations within the reactive mat throughout the monitoring period (Appendixes 1A and 1B), similar to observations in the laboratory column tests (Lorah and others, 2008). Sulfide was commonly detected at concentrations less than 0.1 to less than $0.25 \mathrm{mg} / \mathrm{L}\left(1.6 \times 10^{-3}\right.$ to $\left.3.9 \times 10^{-3} \mathrm{mM}\right)$. Ferrous iron consistently decreased by one to two orders of magnitude from 1 to $3 \mathrm{ft}$ below the reactive mat to within the reactive mat (Appendixes 1A and 1B), despite the generation of ferrous iron from the ZVI zone. The lack of both iron and sulfide within the mat may indicate iron sulfide precipitation in the mat. Precipitated iron sulfide has been observed within ZVI barriers (Vikesland and others, 2003).

The immediate dosing of electron donor within the organic matrix (crab compost and chitin) resulted in a rapid establishment in methane concentrations throughout the mat with relatively high concentrations detected during the first monitoring event in November-December 2004 (table 8, figs. $18 \mathrm{a}, \mathrm{b})$. Methanogenic conditions were maintained, especially immediately above the ZVI-organic zone (PTBC), throughout the monitoring period (fig. 18a). A decline in methane concentrations was observed over the winter months in sampling points nearest to land surface in the organic zone (PTBB and PTBC), as evident in the decreased concentrations between November 2004 and March 2005 (figs. 18a,b). Between May and September 2005, methane concentrations increased again.

Concentrations of methane detected in native sediments deeper than $3 \mathrm{ft}$ bls underneath and surrounding the reactive mat were consistent with pre-installation concentrations (Appendix 1). Immediately below the reactive mat, from $1 \mathrm{ft}$ to approximately $3 \mathrm{ft}$ bls (PTN and PTCA levels, respectively), methane concentrations gradually increased consistent with the in-mat fluctuations, particularly between May and September 2005, as shown by the data from the PTB7/PTC4 monitoring location (fig. 18c). Increased methane concentrations in these underlying wetland sediments may indicate downward transport of WBC-2 from the mat and its subsequent growth and methane production, or downward transport of methane itself with tidal recharge of groundwater and surface water within these sediments.

Hydrogen previously has been used as an indicator of dechlorination activity in aquifers as a result of its metabolic use by dehalorespiring bacteria (Maymó-Gattel and others, 1997). Hydrogen distribution within the reactive mat did not 
(A)

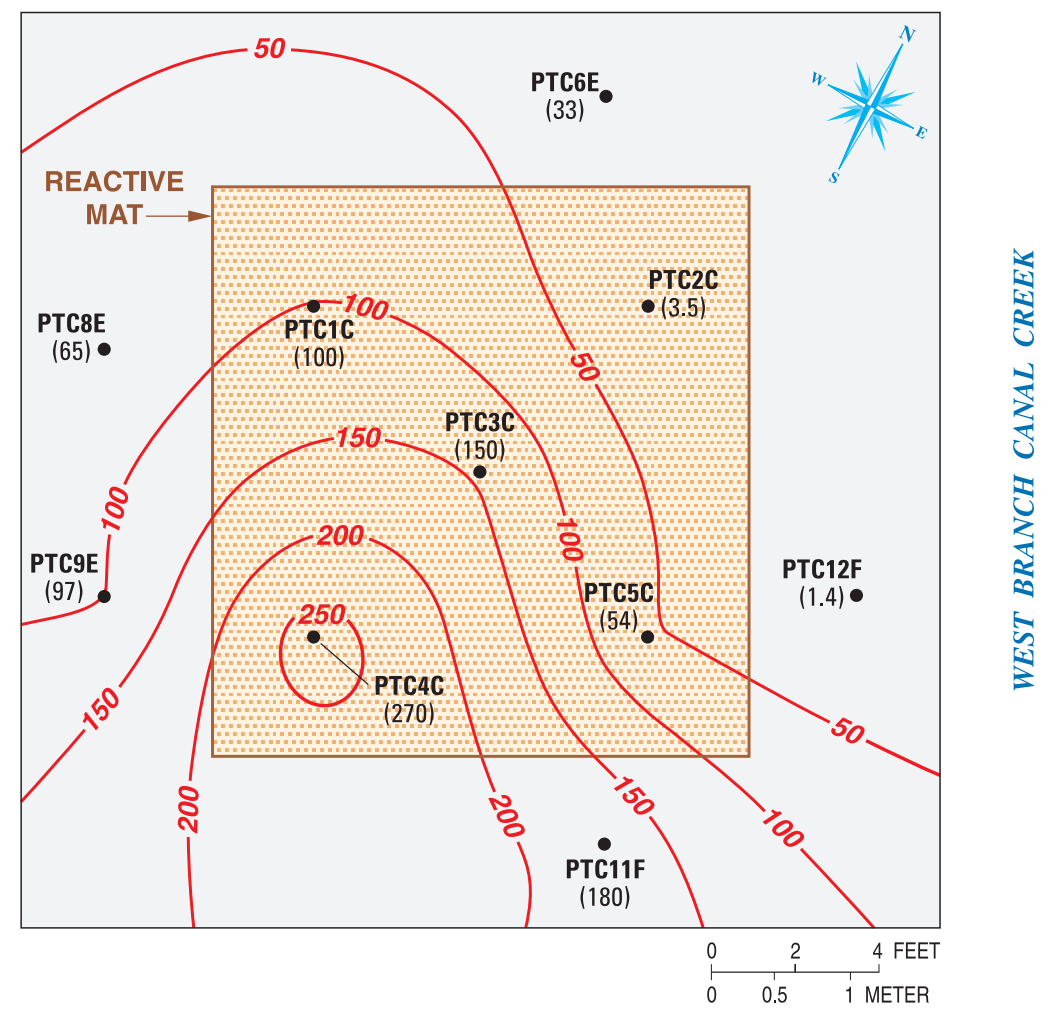

(B)

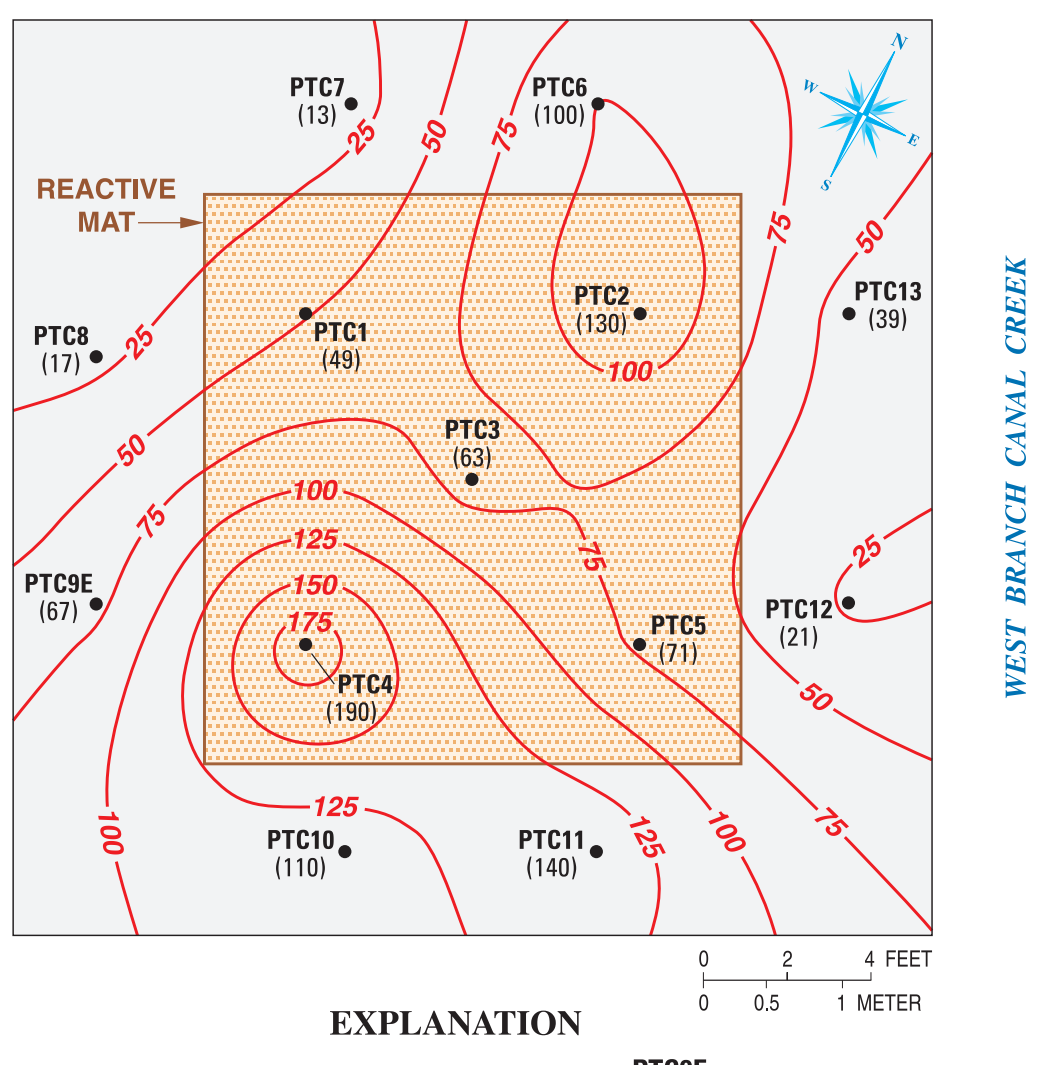
— 100 - LINE OF EQUAL CONCENTRATION OF TOTAL CHLORINATED VOLATILE ORGANIC COMPOUNDS, IN MICROMOLAR [Interval is (A) 50 micromolar and (B) 25 micromolar.]

PTC9E (Number in parentheses is concentration, in micromolar.)

Figure 12. Baseline distribution of total chlorinated volatile organic compounds at $(A)$ the top of the Canal Creek aquifer, and $(B)$ in wetland sediments beneath the seep 3-4W reactive mat pilot test area, West Branch Canal Creek, Aberdeen Proving Ground, Maryland, August-September 2004. 


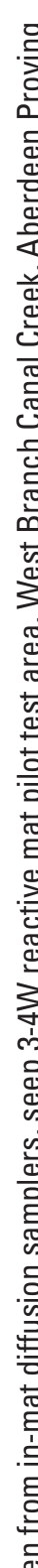

|

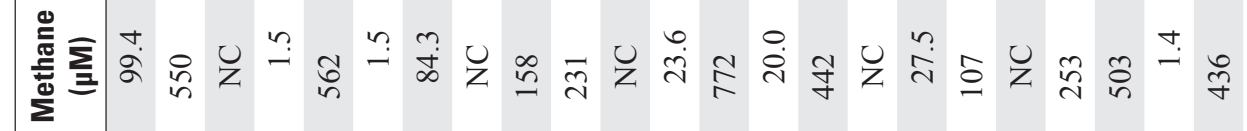

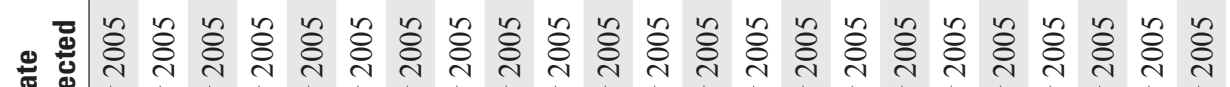

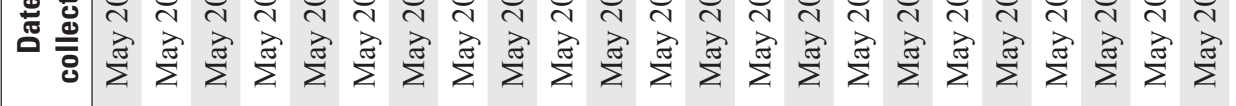

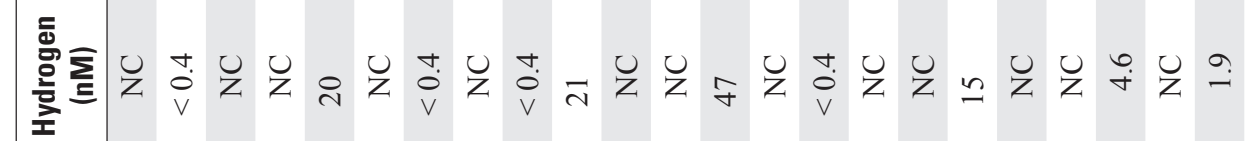

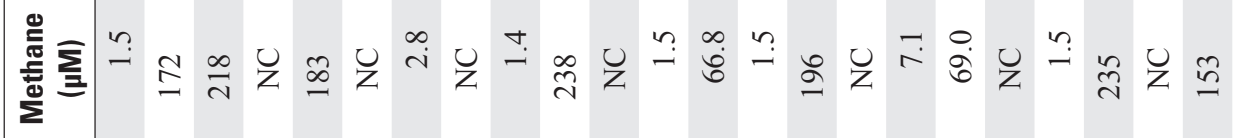
๘

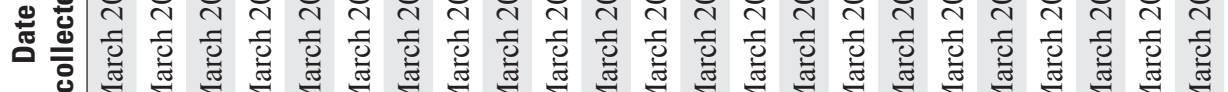
产离至 ઇ

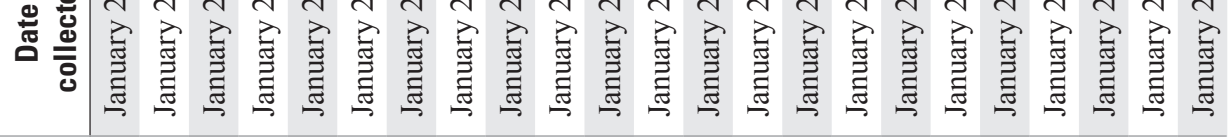

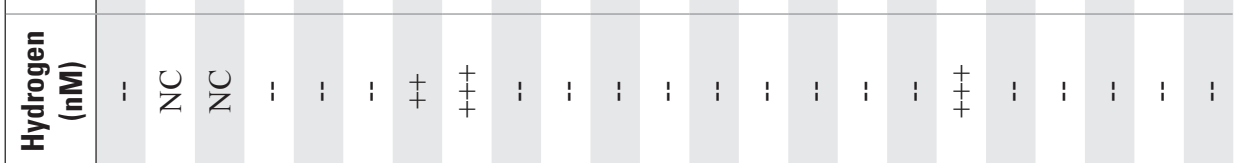
는 융 空迹 品 站苍 등 흠 등 黄 要 产 它

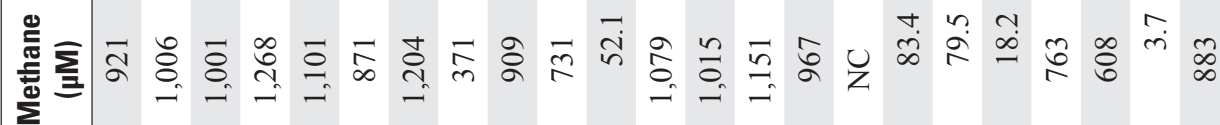




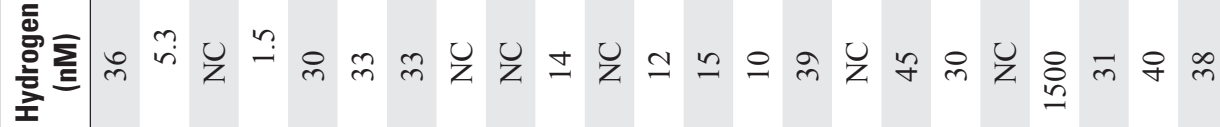

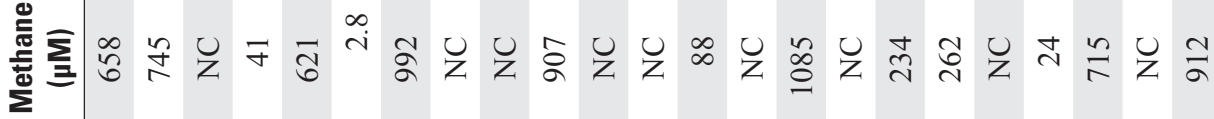

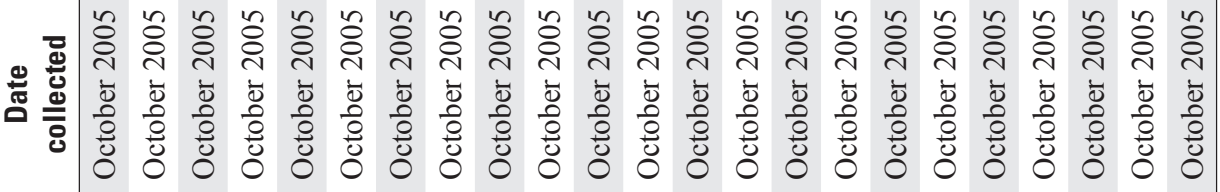

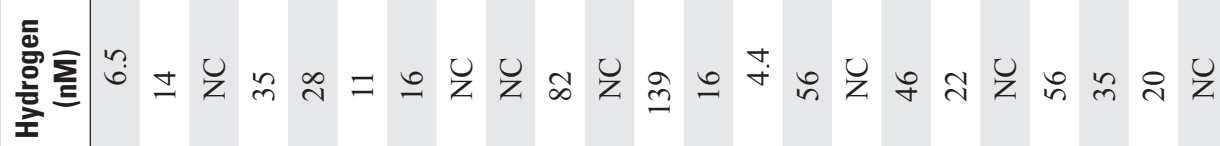

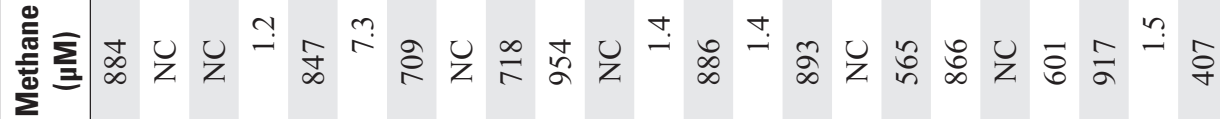

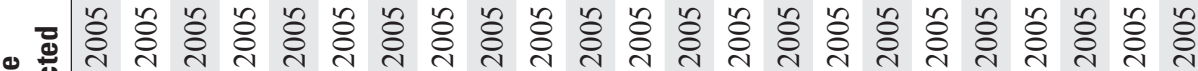

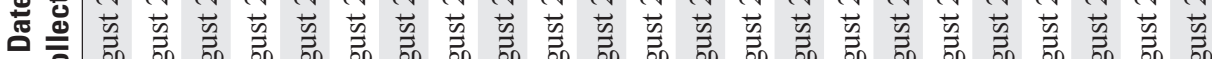

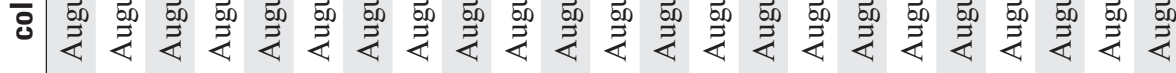
要

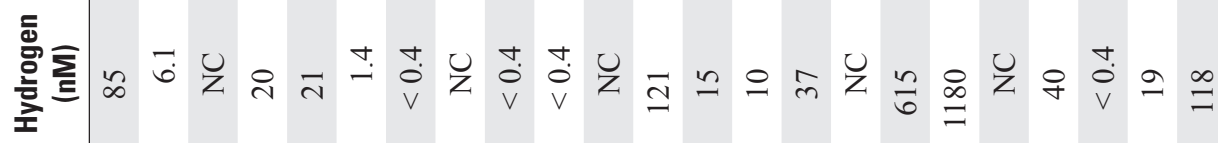

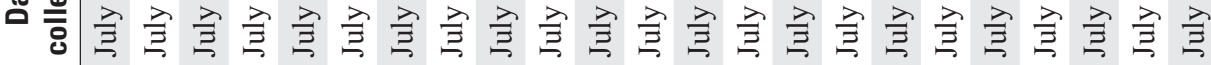

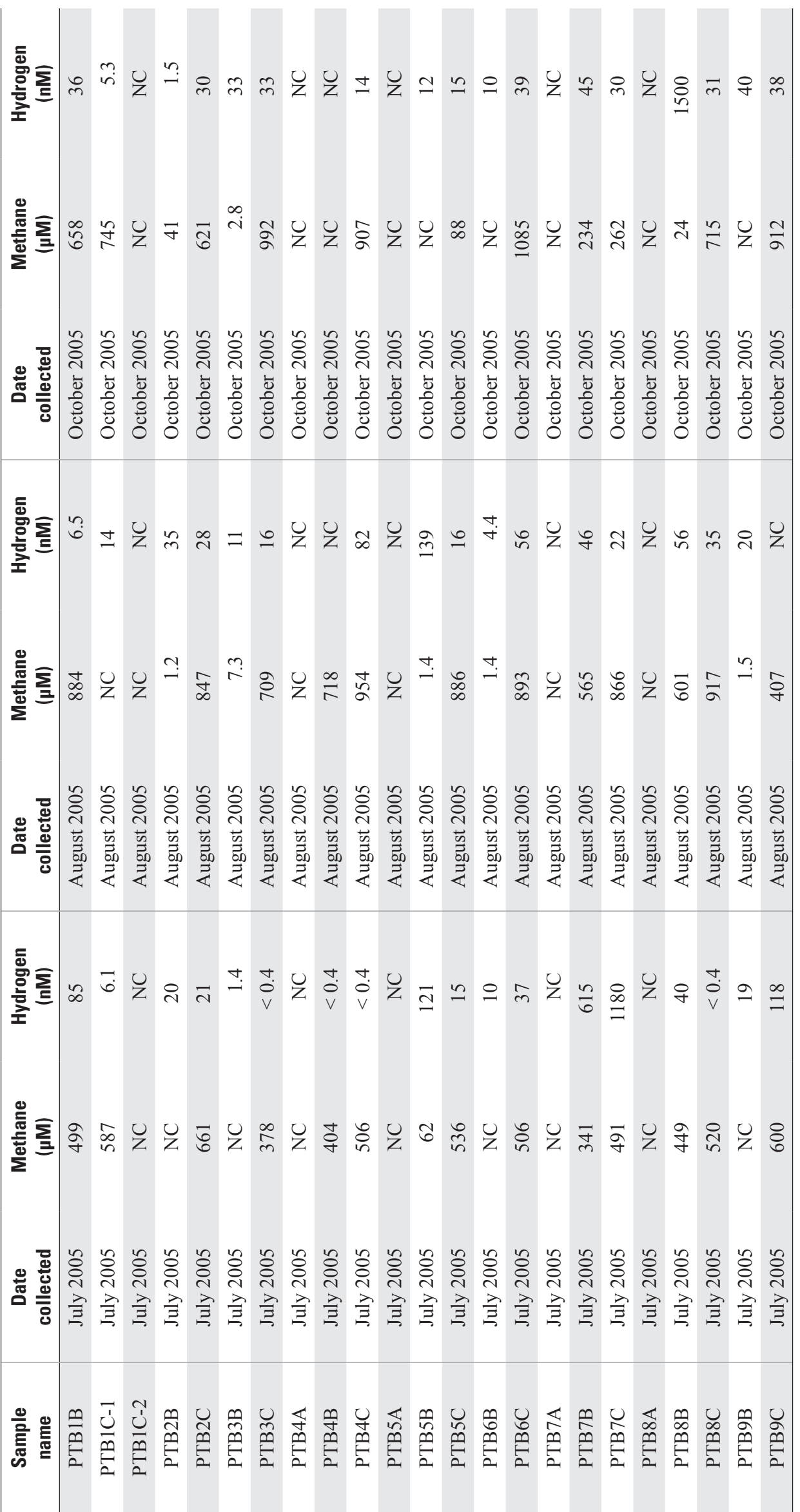


(A)

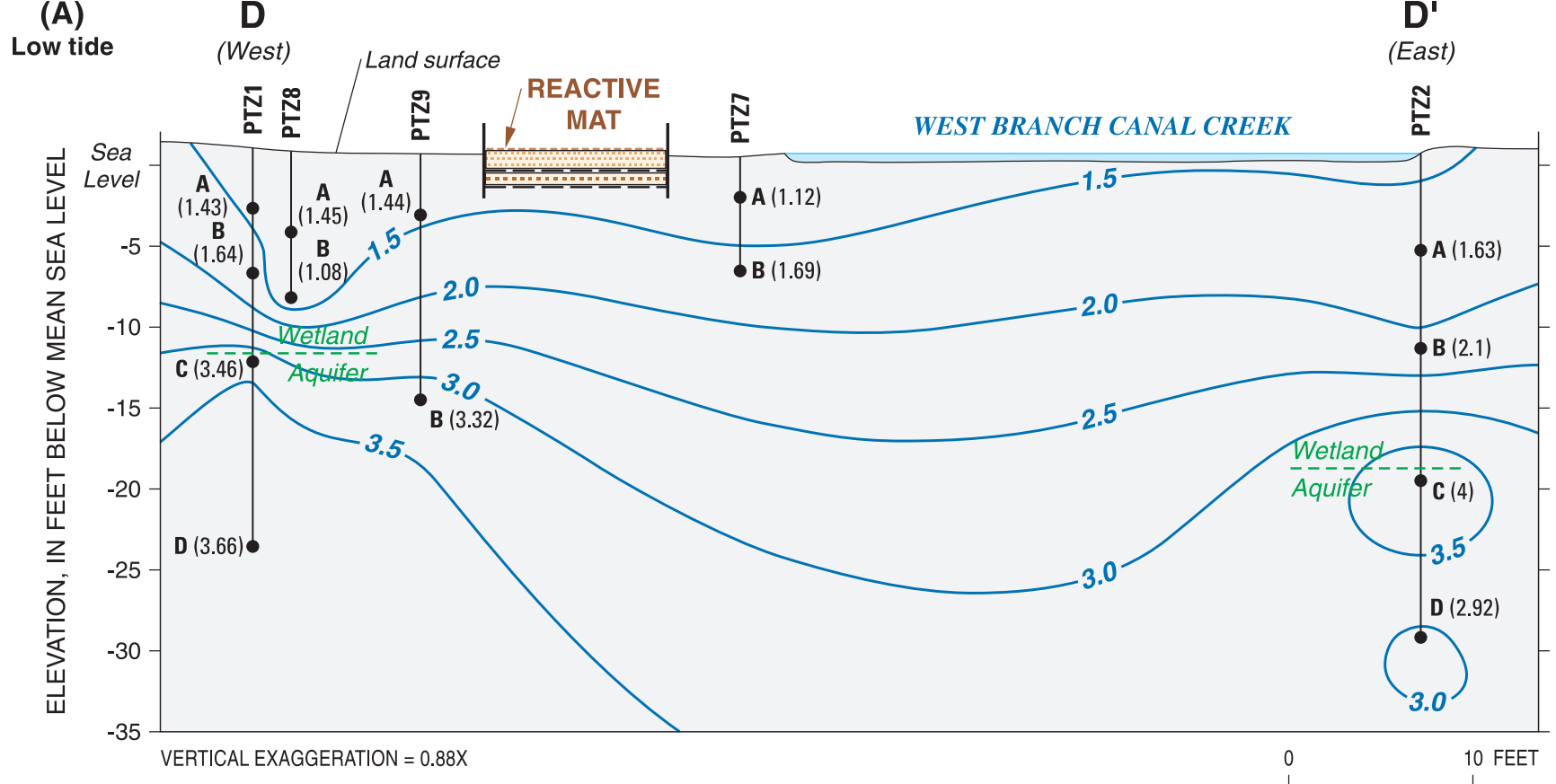

(B)

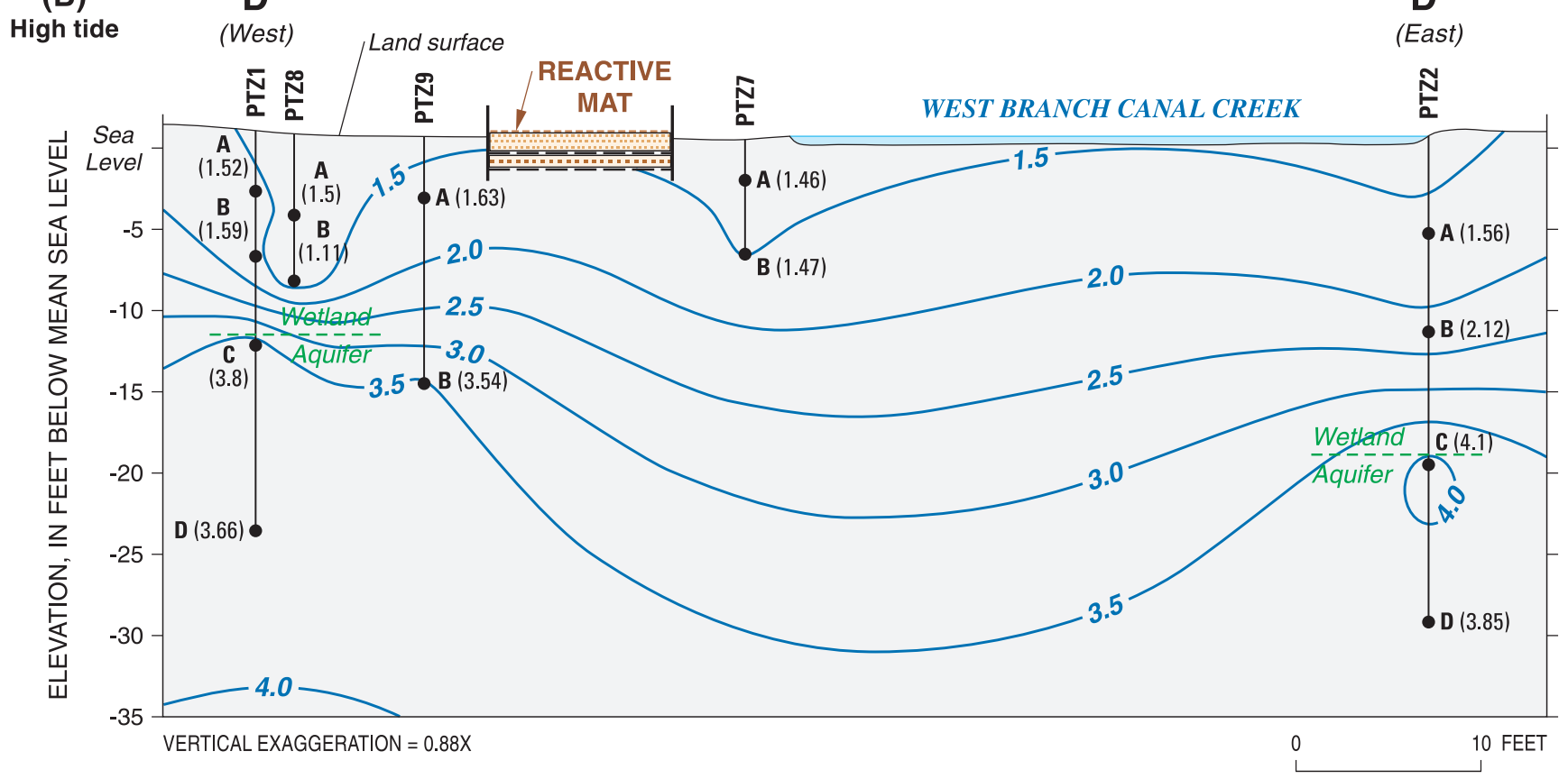

\section{EXPLANATION}

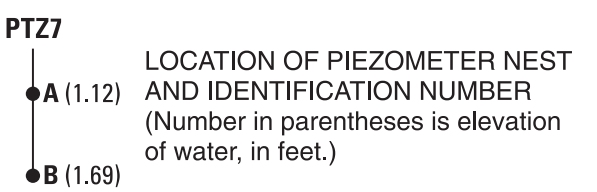

$-2.0-$ LINE OF EQUAL POTENTIOMETRIC SURFACE,
IN FEET (Interval is 0.5 feet.)

Figure 13. Section D-D' showing baseline mean hydraulic head distribution at the seep 3-4W reactive mat pilot test area, West Branch Canal Creek, Aberdeen Proving Ground, Maryland, August-September 2004, $(A)$ low tide and $(B)$ high tide. 
(A) $\quad \mathrm{E}$

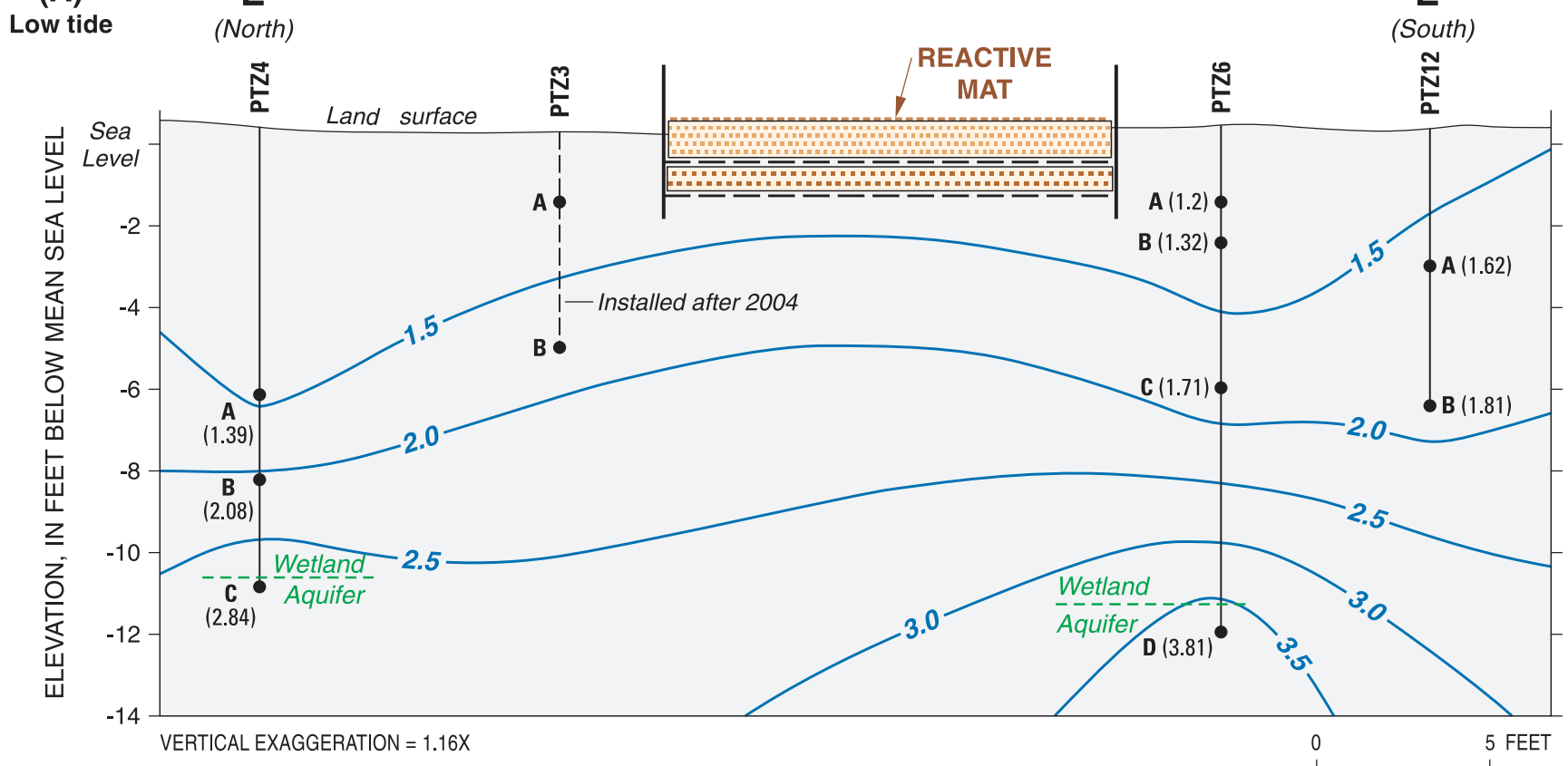

(B) $\quad \mathrm{E}$ High tide (North)

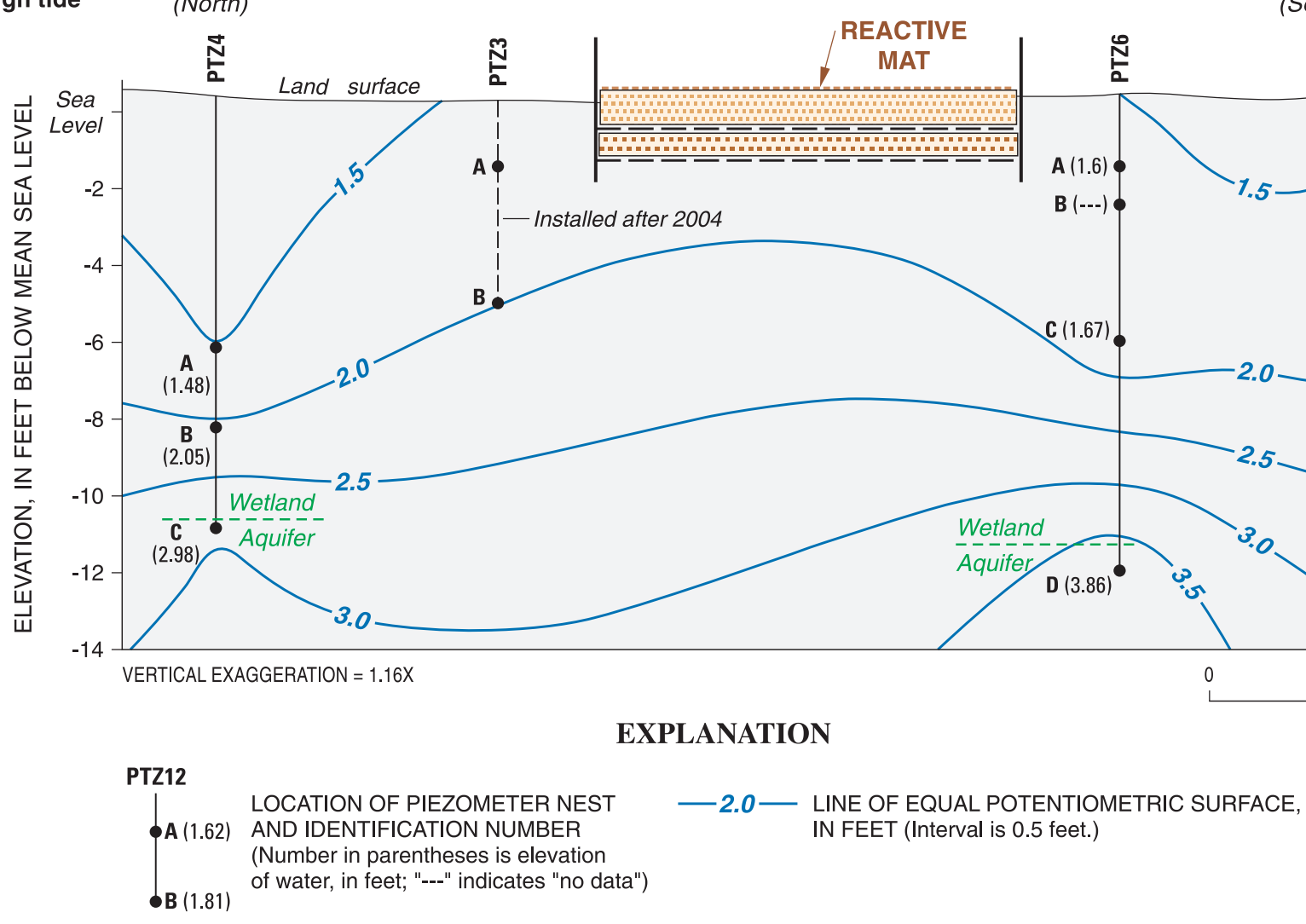

Figure 14. Section E-E' showing baseline mean hydraulic head distribution at the seep 3-4W reactive mat pilot test area, West Branch Canal Creek, Aberdeen Proving Ground, Maryland, August-September 2004, $(A)$ low tide and $(B)$ high tide. 


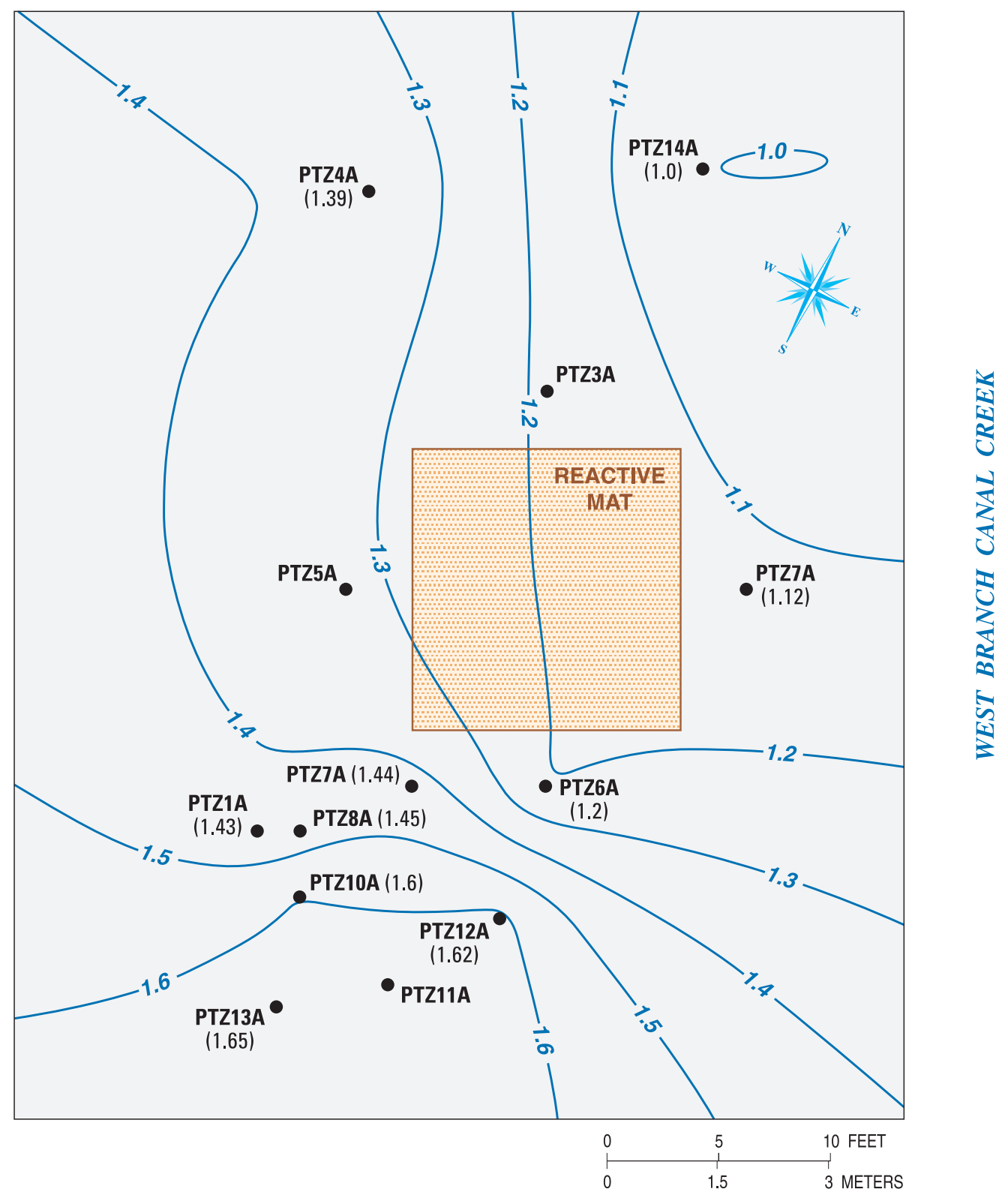

EXPLANATION

- 1.3 - LINE OF EQUAL HYDRAULIC HEAD, IN FEET (Interval is 0.1 foot.)

PTZ4A

(1.39)

PIEZOMETER LOCATION AND

IDENTIFIER (Number in parentheses is hydraulic head, in feet.)

Figure 15. Baseline planar distribution of hydraulic head in the upper wetland sediments at low tide, seep 3-4W reactive mat pilot test area, West Branch Canal Creek, Aberdeen Proving Ground, Maryland, September 2004. 
(A) $\quad \mathbf{Y} \quad \mathbf{Y}^{\prime}$ chloromethanes (West) (East)

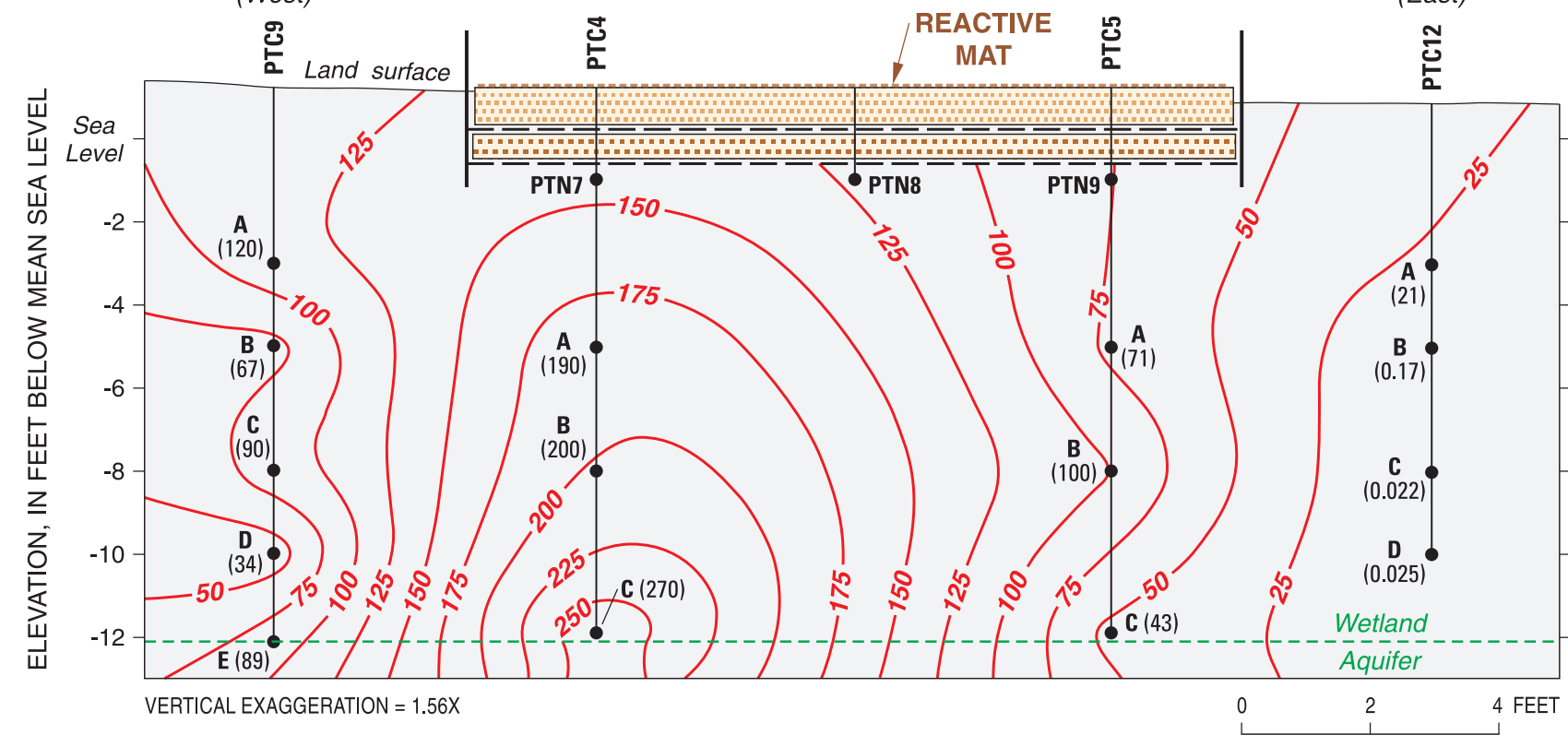

$\begin{array}{lll}\text { (B) } \quad \mathrm{Y} & \mathbf{Y}^{\prime}\end{array}$

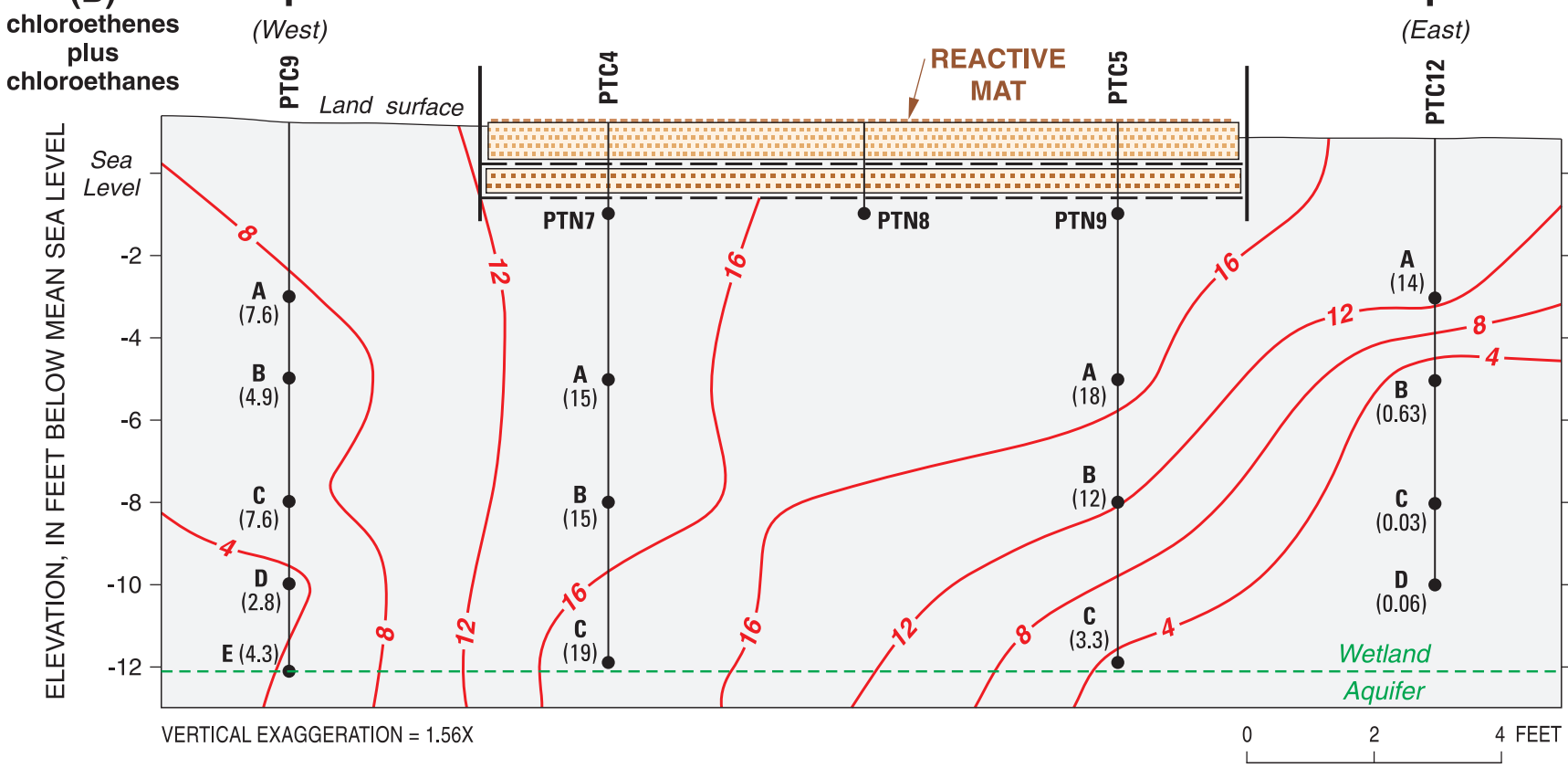

EXPLANATION

PTC9

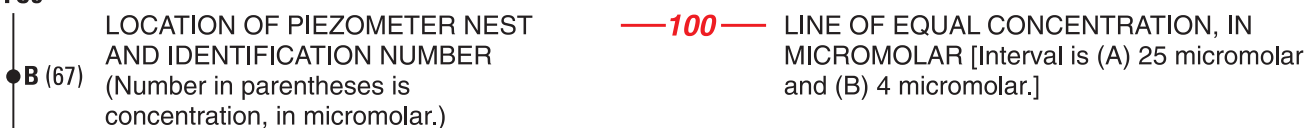

Figure 16. Baseline distribution of chlorinated volatile organic compounds in section $Y^{\prime} Y^{\prime}$ at the seep 3-4W reactive mat pilot test area, West Branch Canal Creek, Aberdeen Proving Ground, Maryland, August-September 2004, $(A)$ chloromethanes and $(B)$ chloroethenes plus chloroethanes. 
(A)

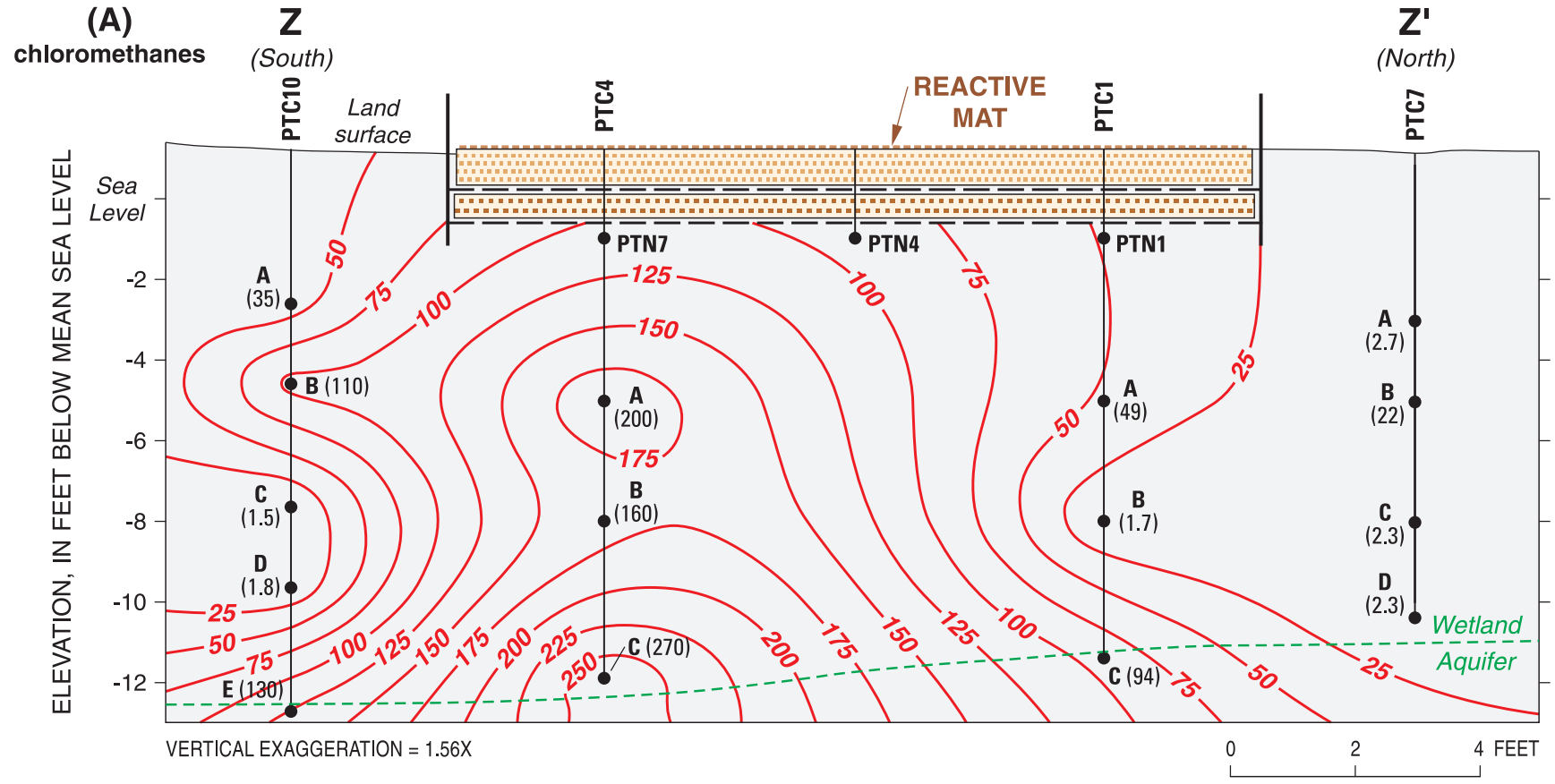

(B) Z

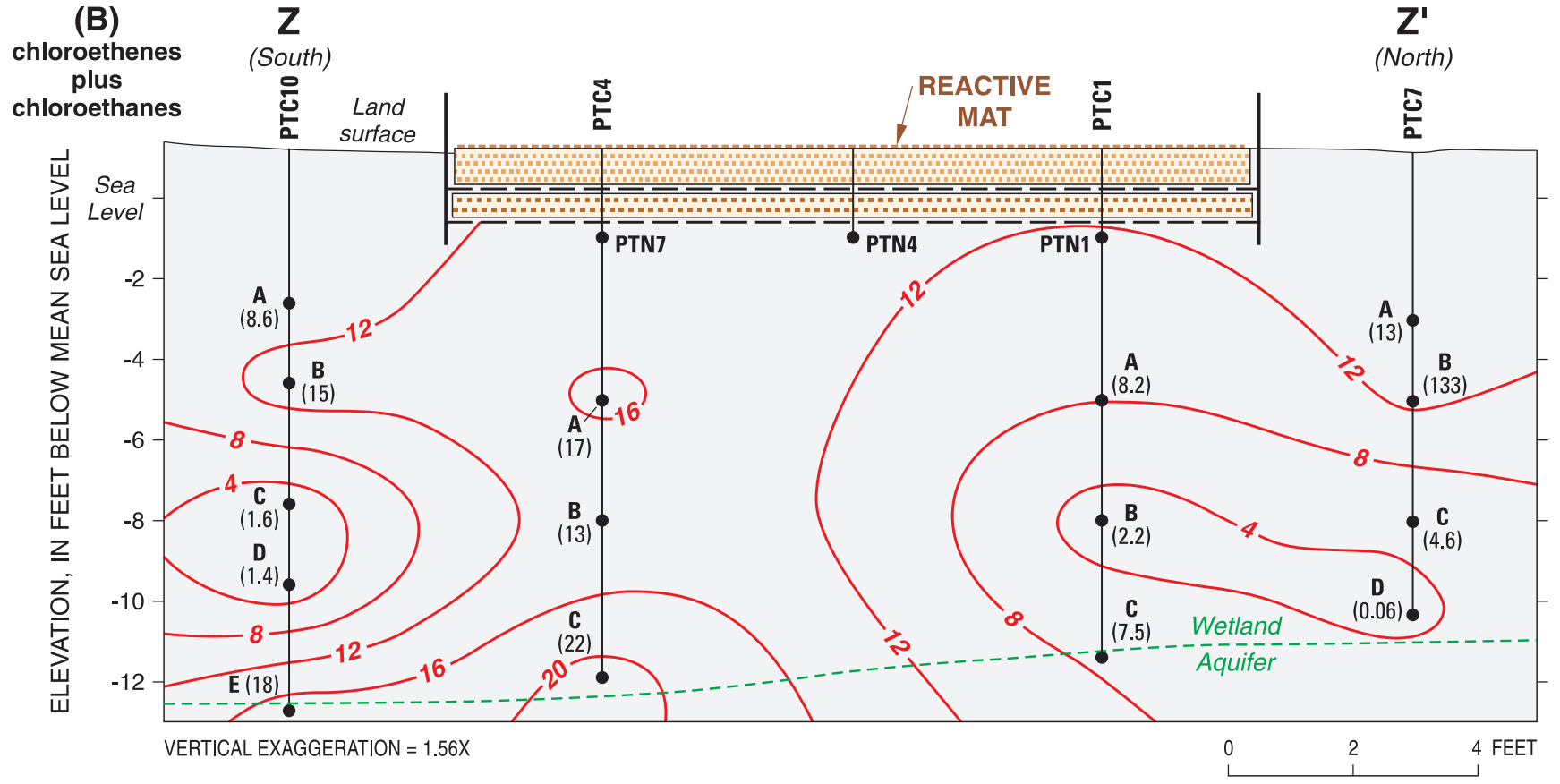

EXPLANATION

PTC10

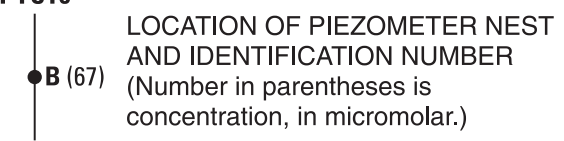

-100- LINE OF EQUAL CONCENTRATION, IN
MICROMOLAR [Interval is (A) 25 micromolar
and (B) 4 micromolar.]

Figure 17. Baseline distribution of chlorinated volatile organic compounds in section Z-Z' at the seep 3-4W reactive mat pilot test area, West Branch Canal Creek, Aberdeen Proving Ground, Maryland, August-September 2004, $(A)$ chloromethanes and $(B)$ chloroethenes plus chloroethanes. 
consistently correlate with methane concentrations, particularly prior to May 2005 (table 8). The hydrogen concentrations detected also were quite variable, and in some cases, ranged from two to three orders of magnitude, with maximum hydrogen concentrations occurring in both the presence of and absence of methane (table 8). Hydrogen detection did correspond to degradation of chlorinated VOCs, particularly after March 2005, and possibly indicated the growth of the dechlorinating bacteria in the reactive mat during this timeframe.

In addition to evaluating redox indicators for favorable biodegradation conditions for VOCs, microbial community activity tests were conducted periodically to assess the dechlorinating ability of the microorganisms established in the reactive mat, which were assumed to be WBC-2. When TeCA was added to a subsample of reactive mat matrix collected from PTB7 in November 2004, removal of TeCA and all its associated daughter compounds occurred within 20 days (fig. 19a). Following the winter months, the activity test was repeated in the same areas of the reactive mat. Although the March 2005 removal rates were lower than those in November 2004, all added TeCA and its daughter compounds were subsequently removed, even in the presence of PCE (fig. 19b). These results indicated that microbial activity, stimulated at least in part by the WBC-2 bioaugmentation within the reactive mat, was sufficient to maintain dechlorination activity even following the winter months, and that no additional bioaugmentation or biostimulation was required.

\section{Volatile Organic Compound Distribution and Mass Removal}

The distribution of total VOC concentrations in the top of the aquifer and the wetland sediments ( $5 \mathrm{ft}$ and $1 \mathrm{ft} \mathrm{bls}$ ) below the reactive mat (figs. 20a,b), and in piezometer PTZ2 on the eastern side of the creek (fig. 5a; Appendix 3) was used to evaluate changes to VOC input to the reactive mat during the monitoring period. Whereas some variations of VOCs in the aquifer were noted in the footprint of the mat, the overall distribution of underlying VOCs was largely consistent with pre-installation concentrations (figs. 20a,b). Maximum VOC concentrations were typically detected during the spring at all depths. Total VOC concentrations in piezometer PTZ2E (screened at approximately $38 \mathrm{ft}$ bls) reached a maximum of $18 \mathrm{mg} / \mathrm{L}(125 \mu \mathrm{M})$ during March 2005 , decreased to $11 \mathrm{mg} / \mathrm{L}$ $(79 \mu \mathrm{M})$ in May 2005 , and ranged from only 0.73 to $1.9 \mathrm{mg} / \mathrm{L}$ (5.2 to $8.8 \mu \mathrm{M}$ ) during other sampling periods (Appendix 3). The total VOC concentrations at the top of the Canal Creek aquifer in the central and southwestern parts of the mat area reached a maximum in May 2005, with a 40- to $70-\mu \mathrm{M}$ increase compared to March 2005 (fig. 20a), indicating the possible transport of a slug of contaminants from this deep zone at PTZ2E to the reactive mat between March and May 2005. Variations in VOC concentrations observed within the reactive mat (figs. 20d,e) were consistent with VOC loading from underlying depths (though the overall concentrations were much lower), and were focused in the southwest corner. At the base of the organic zone (PTBB level), total VOC concentrations were highest in January and March 2005, consistent with the decrease in methane concentration described in the previous section (fig. 20e). Overall, VOC distribution was temporally consistent within the mat during the monitoring period (figs. 20d,e). Therefore, further comparisons between pre- and post-installation concentrations are presented for the August 2005 monitoring event as a representative month during the monitoring period.

To evaluate VOC distribution and reduction, VOC concentrations within the mat area are shown in planar twodimensional isoconcentrations at various depths within the underlying wetland sediments and reactive mat (figs. 21a-f and 22a-c), and in vertical VOC concentration profiles at given monitoring locations (figs. 23a-c). Despite the large difference in concentration between chloromethanes and chloroethenes and chloroethanes, the distribution of the three contaminant groups within the reactive mat was fairly consistent. Maximum concentrations at all depths during all seasons occurred primarily in the southwestern-western area of the mat footprint. The highest concentrations were located along the southwest boundary and extended beyond the boundaries in all directions below the mat (figs. 21a,b and 22a,b). In most cases, little to no change in the overall distribution and concentration of chlorinated compounds was observed between the aquifer and $1 \mathrm{ft}$ bls in the wetland sediments (figs. 21a,d). This spatial distribution was consistent with pre-installation conditions of the aquifer (figs. 16a,b and 17a,b) and in various depths within the wetland sediments (figs. 21a-f and 22a-c). The decrease in VOC concentrations from just below the reactive mat (PTN) to immediately above the ZVI-organic zone (PTBC) was typically at least an order of magnitude. Further removal was frequently observed between the ZVI-organic (PTBC) and organic (PTBB) zones. Variation between the isoconcentrations within the reactive mat (figs. 21e,f, and fig. 22c) was generally small despite significant concentration gradients observed at deeper depths within the same area, which is indicative of substantial mass removal over the narrow mat thickness.

The distribution of total VOCs in the untreated seep area outside of the reactive mat was relatively consistent over the monitoring period up to the most shallow monitoring depth of $3 \mathrm{ft}$ bls for total VOCs, particularly along the southwestern mat perimeter (fig. 24a). Greater variation was apparent in the northeastern perimeter wells (fig. 24b). Increased porewater concentrations of chloromethanes in May 2005 near PTC6 and PTC13 at this shallow depth corresponded to the increased VOC concentrations observed on the eastern side of the creek channel in piezometer PTZ2.

Chloromethanes typically decreased from west to east through both reactive mat zones (figs. 21d,e), consistent with the distribution within the wetland sediments immediately below the mat, and therefore, with the loading from these sediments (fig. 21c). The consistent, increased loading of chloromethanes to the southwestern corner of the mat appeared to 


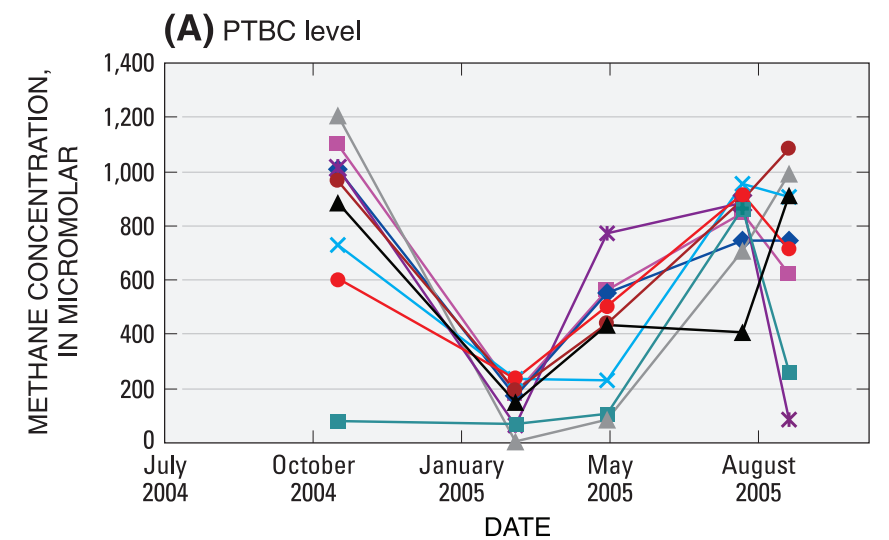

EXPLANATION

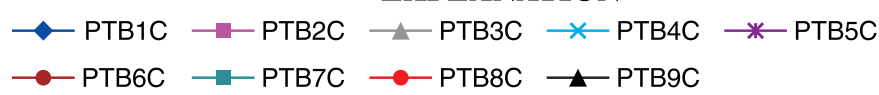

(C) In profile at PTB7/PTC4

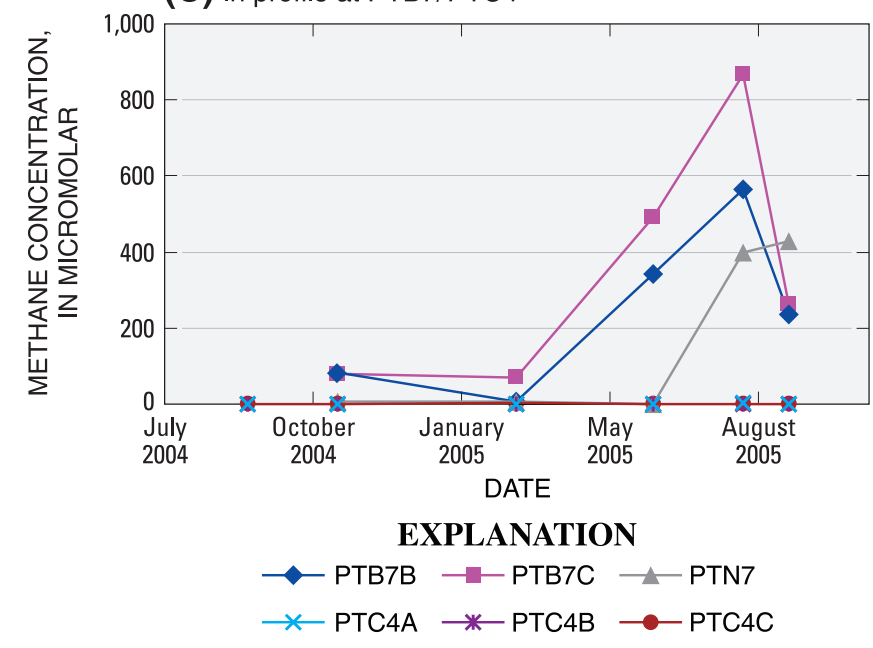

(B) PTBB level

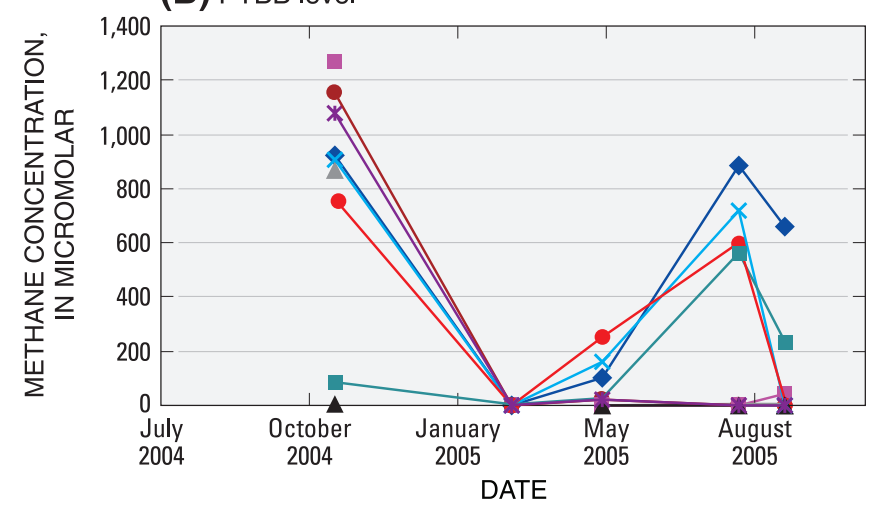

EXPLANATION

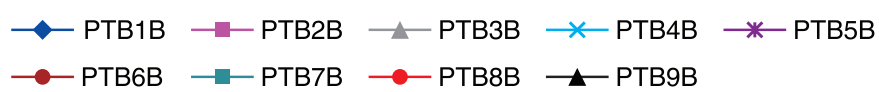

VERTICAL PROFILE

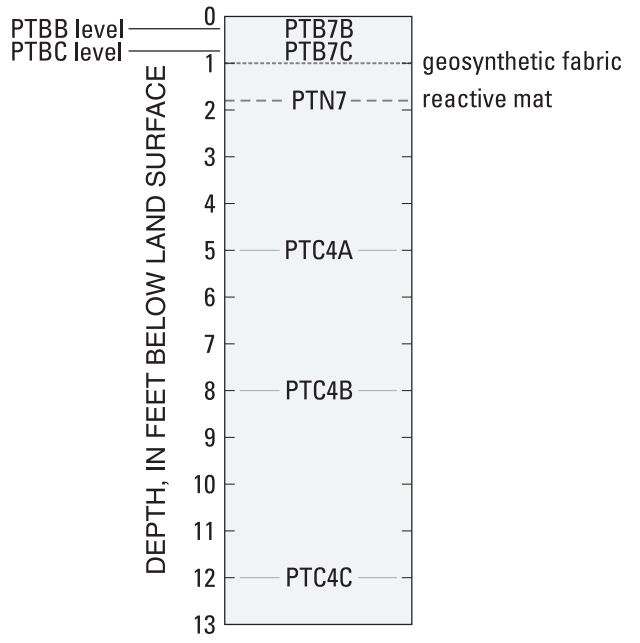

Figure 18. Methane concentrations in the reactive mat pilot test at seep area 3-4W, West Branch Canal Creek, Aberdeen Proving Ground, Maryland, (A) PTBC level, (B) PTBB level, and (C) in profile at PTB7/PTC4.

slightly decrease the degradation efficiency of chloroethenes and ethanes in both mat zones in this area (fig. 22c). This measured co-contaminant effect was similar to observations made in laboratory column tests, where degradation of TeCA was slightly reduced with long-term loading of CT and CF (Lorah and others, 2008).

Chloromethanes were detected at more sampling locations in the ZVI-organic (PTBC) zone of the mat in January and March 2005 than were detected during warmer months (fig. 20d), likely, in part, due to the low temperature at shallow depths during the winter months. Methane concentrations also declined throughout this treatment zone during the winter months (fig. 18a), and decreased VOC degradation efficiency was affirmed by the activity tests that showed reduced removal rates in March 2005 compared to November 2004 (figs. 19a,b).
In addition to the effects of temperature on biodegradation efficiency, the reactive mat received different VOC loading amounts during the pilot test that likely decreased the biodegradation efficiency within the mat. Increased loading from the aquifer was observed particularly in May 2005, as described at the beginning of this section (fig. 20c). In spite of the increased loading, methanogenic conditions were maintained during May 2005 and the thickness of the mat appeared to be adequate to facilitate a decline in overall concentrations through the organic zone (fig. 20e). The decrease in loading observed during later sampling events appeared to improve the degradation efficiency of chloromethanes (fig. 21f) and chloroethane and chloroethenes (fig. 22c) in the ZVI-organic zone.

Vertical profiles of total VOC concentrations below and within the mat were consistent over the monitoring period (fig. 23) and indicated that the primary source of VOCs to the 
(A) November 2004

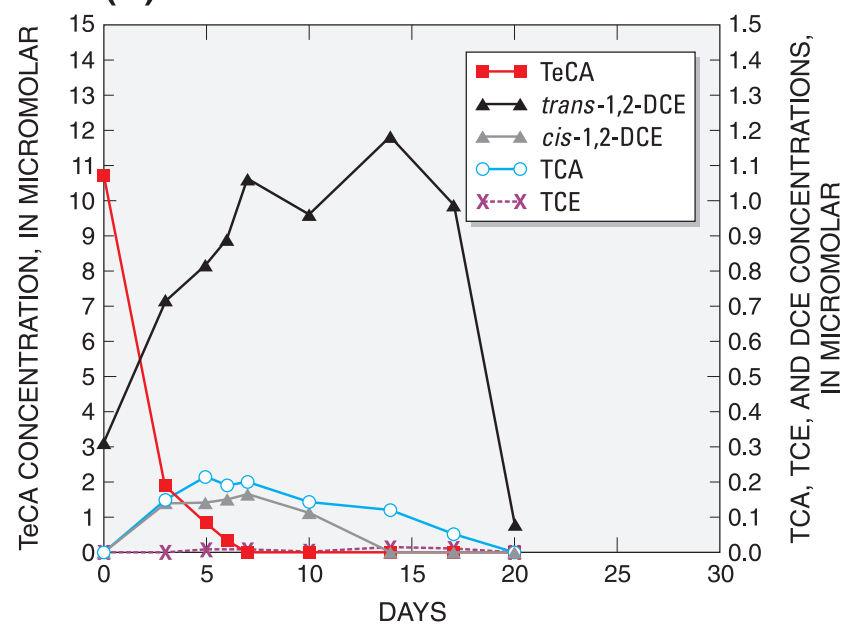

(B) March 2005

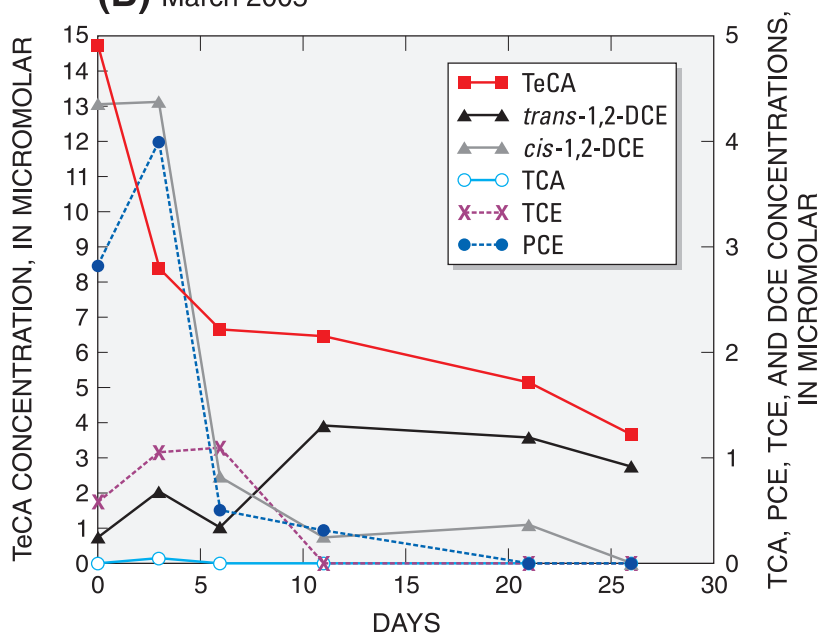

Figure 19. Concentrations of 1,1,2,2-tetrachloroethane (TeCA), and daughter compounds 1,1,2-trichloroethane (TCA), trichloroethene (TCE), trans-1,2-dichloroethene (trans-1,2-DCE), and cis-1,2-dichloroethene (cis-1,2-DCE) in activity tests from the reactive mat pilot test at seep area 3-4W, West Branch Canal Creek, Aberdeen Proving Ground, Maryland, (A) November 2004 and (B) March 2005. [Note: Tetrachloroethene (PCE) was present in mat sample in March 2005.]

reactive mat was likely in the aquifer in the southwest corner (fig. 23a). Profiles of compound concentrations were relatively consistent over the monitoring period throughout the mat area compared to concentration profiles prior to mat installation (figs. 23a-c). In the southwest corner, total VOCs decreased with shallower depths and were completely removed within the reactive mat (fig. 23a). In the northeast and southeast corners of the reactive mat, maximum concentrations of VOCs were detected at shallower depths within the wetland sediments compared to the southwest corner (figs. 23b,c).

Vertical contaminant profiles of individual VOCs (both parent and daughter compounds) were examined to assess VOC mass removal (complete degradation to non-toxic endproducts) through the mat. Since concentrations were consistent over the monitoring period (figs. 23a-c), results are only shown for March and June 2005, in the southwest (PTC4) area of maximum concentration from the aquifer upwards through the reactive mat (figs. 25a-d). In the vertical profile with depth within the wetland sediments, parent compounds CT, CF, PCE, TCE, and TeCA were conserved in the vertical direction to a depth of $5 \mathrm{ft}$ bls (figs. 25a,b; location PTC4), similar to parent compounds found in the PDS investigations in the upper $2 \mathrm{ft}$ prior to mat installation (Majcher and others, 2007; fig. 11). A decline in CT was apparent between $5 \mathrm{ft}$ and $1 \mathrm{ft}$ bls of wetland sediment, but substantial CF mass remained immediately below the reactive mat with lower concentrations of PCE, TCE, TeCA, and HCA during the entire monitoring period. Through the mat itself, transient appearance of daughter compounds TCE, cis-1,2-DCE, VC, and methylene chloride was observed, but mass balances of parent and daughter compounds were poor over the narrow thickness of the mat (figs. 25a-d). These transient daughter compounds also were detected in areas of efficient natural attenuation, often with poor mass balances (Lorah and others, 1997). Ethene and ethane were detected in the two reactive zones, indicative of complete dechlorination (figs. 25a,c). Incomplete removal of CF, methylene chloride, and TCE was apparent during the March sampling event (figs. 25a,b). Removal of these contaminants improved through the summer, however, with the reappearance of ethene and ethane end-products (fig. 25c). Overall, these results are significantly different from the pre-installation results (fig. 10), where little to no removal of parent VOCs was observed in the upper sediments.

Estimates of mass removal over time between the base of the mat (PTN) and the middle of the organic zone (PTBB) were made over the monitoring period to compare to the design goal of 90-percent removal of total VOCs (table 9). These estimates were based on a reactive mat divided into nine sections, with porespace equal to 0.5 , and concentrations equalized in each section based on its center monitoring point. Applying these conservative assumptions, the reactive mat appeared to reach the design goal during the performance period. The median mass removal of chloromethanes and chloroethenes plus chloroethanes during the entire performance monitoring period was 98 and 94 percent, respectively. The minimum removal in the PTBC level occurred in March 2005, likely due to the colder temperatures. The minimum removal in the PTBB level occurred during May 2005 (table 9), likely due to increased loading. 

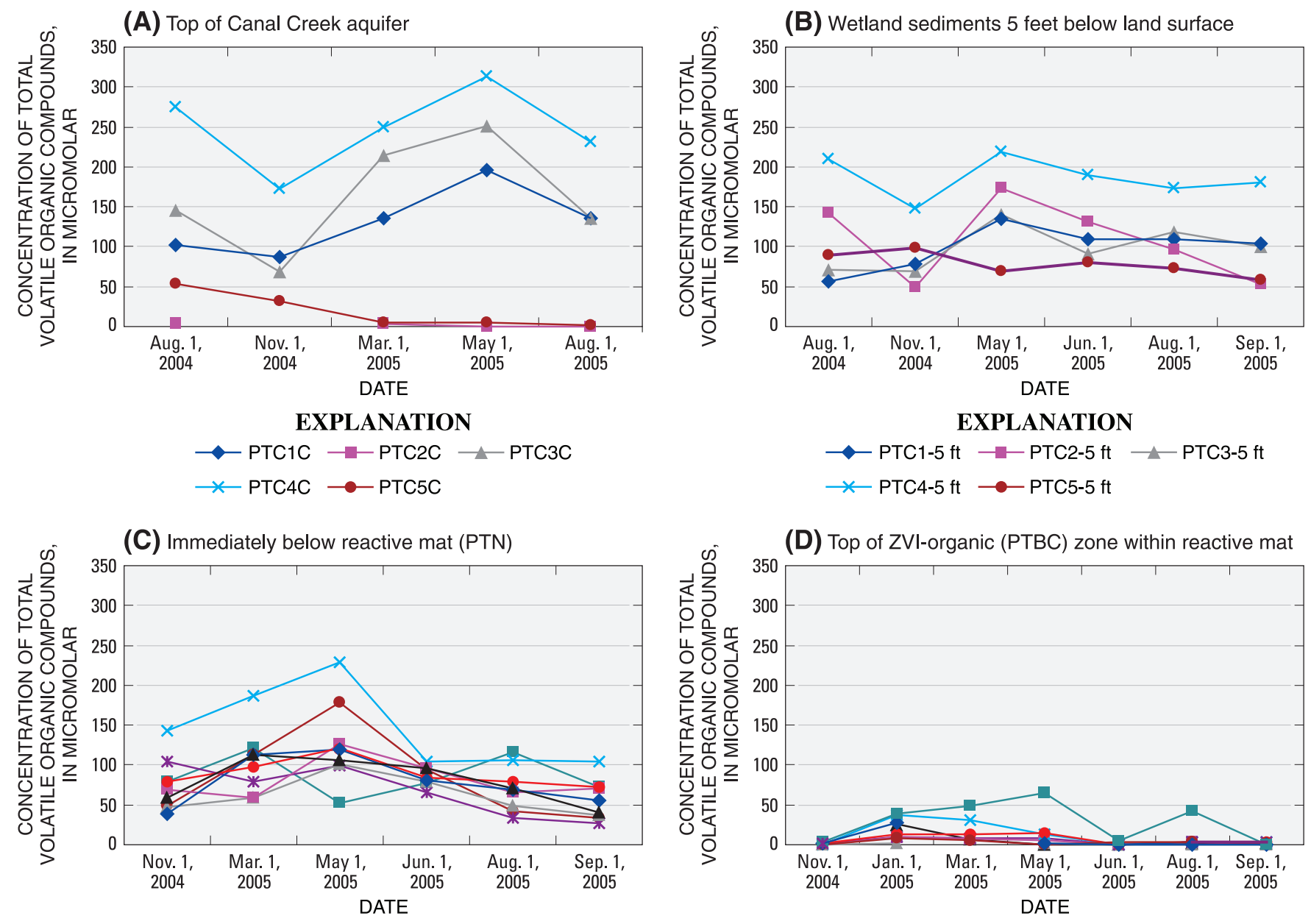

EXPLANATION
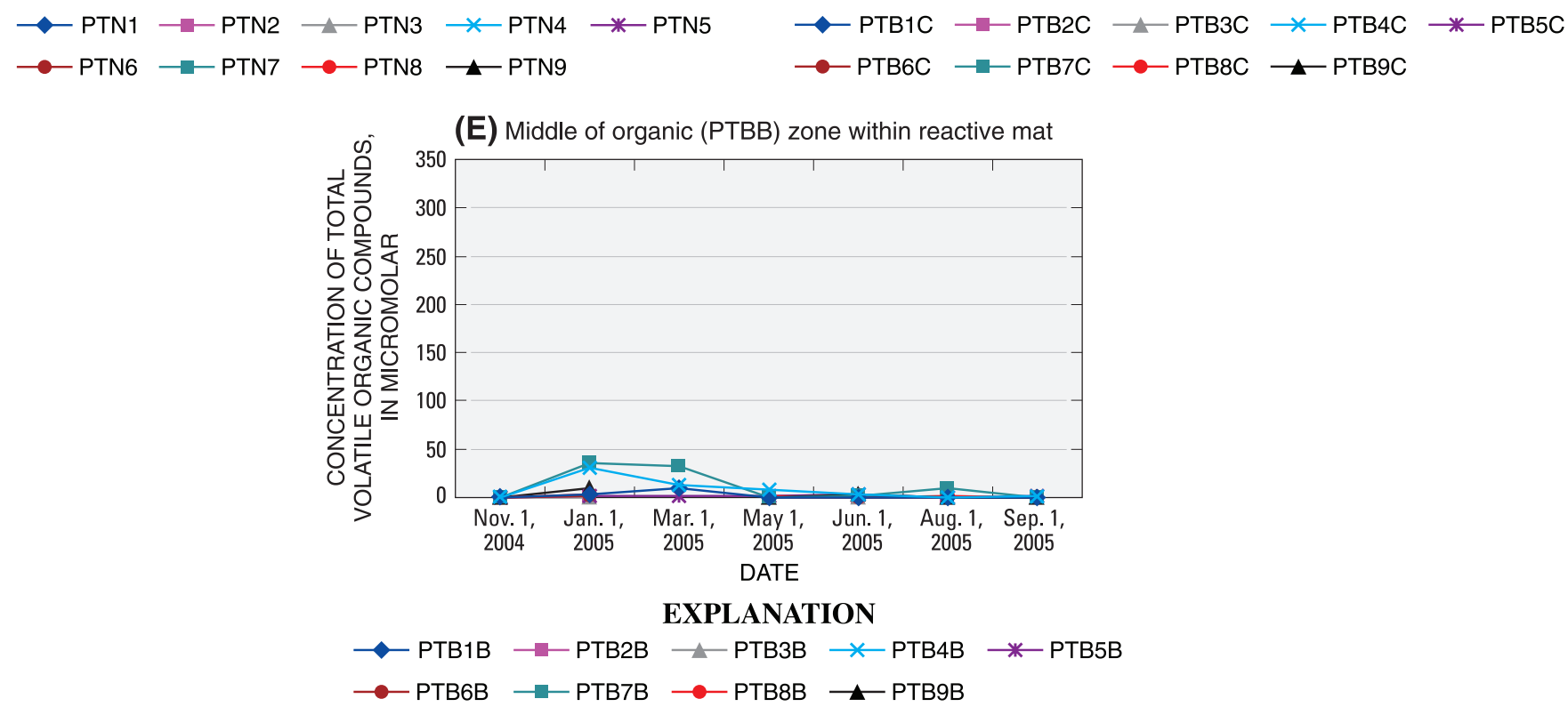

Figure 20. Concentrations of total volatile organic compounds at various depths in reactive mat porewater, seep 3-4W reactive mat pilot test area, West Branch Canal Creek, Aberdeen Proving Ground, Maryland, $(A)$ top of Canal Creek aquifer, $(B)$ wetland sediments 5 feet below land surface, $(C)$ immediately below the reactive mat (PTN), (D) top of the zero-valent-iron (ZVI) -organic (PTBC) zone within the reactive mat, and (E) middle of the organic (PTBB) zone within the reactive mat. 


\section{Assessment of Compatibility with the Wetland System}

A secondary objective of the reactive mat design was to maintain compatibility with the wetland in which it was placed. The reactive mat performance was effective in removing VOCs, based on the design. A discussion of compatibility with the native environment is presented in this section based on hydraulic, geotechnical, and water-quality monitoring and performance metrics.

\section{Geotechnical Integrity}

No local, immediate failure (such as collapse or caving) of the mat or of surrounding wetland sediments was observed during or following mat installation. This indicated that the bearing capacity estimates, and sediment excavation, combined with the subsurface non-woven geotextile used at the base, maintained the integrity of the sediment surface during and following installation. Similarly, the pea gravel appeared to hold fines from the mat surface in place for at least 1 year.

Measurements of surface elevation of the mat between October 2004 and July 2005 showed an average settlement of the mat surface of approximately $0.25 \mathrm{ft}$. Settlement rates were fairly uniformly distributed over the mat surface, with a maximum in the northeast corner of $0.38 \mathrm{ft}$ (closest to the creek), and a minimum of $0.07 \mathrm{ft}$ about $5 \mathrm{ft}$ to the west of the northeast corner. This magnitude of settlement was near the range of settlement predicted for the virgin sediment curves (see Geotechnical Integrity section), confirming that the collected sediments were overconsolidated. The majority of settlement was observed between October 2004 (fig. 26a) and March 2005 (fig. 26b).

Data-collection methods used during this pilot test did not distinguish between settlement of the mat materials and underlying sediment. Measured settlement was likely a combination of both, on the basis of the exposure of the uppermost sampling level (PTBB) of multi-level diffusion samplers within the mat over the monitoring period. This was also indicated by the fact that this apparent settlement within the mat materials was not equal to the total change measured in elevation over time. Future applications of the reactive mat would benefit from the collection of a core of materials periodically throughout the monitoring period to assess settlement and any subsequent reduction in permeability of the mat materials.

The reactive mat maintained its integrity through all seasons, even after the removal of shoring walls in December 2004. The shoring and silt fencing used during construction and as safety mechanisms in the case of failure were removed with the anticipation of the winter freeze-thaw events. While non-native vegetation invaded the reactive mat in summer 2005, which increased the stability of the mat, plants did not appear to be a critical component in its strength based on its stability prior to plant growth. To prevent the invasion of non-native species in the wetland, future applications of the reactive mat would benefit from being seeded with native, wetland plants.

\section{Hydraulics}

In order to assess the hydrologic compatibility of the reactive mat with the wetland, hydrologic monitoring was conducted around the mat throughout the monitoring period. VOCs, which were shown to be good tracers in seep areas (Majcher and others, 2007), also were used to assess the advective transport of contaminated groundwater in wetland sediments below and surrounding the mat. Whereas the incorporation of a geotextile in the reactive mat prohibited hydrologic monitoring across the wetland-mat interface, isolated hydraulic measurements were conducted within the reactive mat during individual monitoring events and are presented in the following section.

\section{Effects on Surrounding Hydrologic Conditions}

During the monitoring period, no atypical hydrologic occurrences were observed in the broader West Canal Creek study area, as evidenced by the upgradient groundwater elevations (in monitoring well CC27A) and upstream tide gage fluctuations. Groundwater elevation in monitoring well CC27A (Appendix 6A), located near the probable VOC source area in the eastern uplands of Canal Creek, was consistent with previous investigations that spanned multiple years (Lorah, Spencer, and McGinty, 2005). The tide gage, considered to be representative of the West Branch Canal Creek, recorded tidal fluctuation over the monitoring period ranging from $-0.3 \mathrm{ft}$ to $3.7 \mathrm{ft}$, consistent with previous investigations (Phelan, Olsen, and others, 2001).

Continuous water levels in selected piezometers indicated a relatively consistent fluctuation over the tidal cycle in the wetland sediments, with decreasing variation with increasing depth bls, as illustrated by piezometer PTZ4 (Appendix 6B). Groundwater discharge along cross-sections D-D' and E-E' remained predominantly vertical following mat installation, the subsequent monitoring period, and during high and low tide as indicated by the potentiometric surface (figs. 27a,b, low tide shown) based on measurements during 11 individual groundwater elevation synoptic events of piezometers to the north, south, east, and west of the mat throughout the monitoring period. The potentiometric surface along the two cross sections was generated using mean groundwater elevations at high $(n=7)$ and low $(n=6)$ tides. Groundwater-level variation was consistent in both direction and magnitude with preinstallation conditions previously described at each tidal stage (figs. 13, 14, 27). Variation between post-installation high and low tides was largely encompassed by the standard deviation among the post-installation synoptic measurements (figs. 27a,b, low tide shown).

Any impacts from the installation of the reactive mat (such as a possible redirection of flow) would be reflected in increased groundwater elevations in piezometers screened in the upper wetland sediments surrounding the reactive mat and a corresponding increase in vertical hydraulic gradients from the aquifer to wetland sediments. At low tide after installation 
(A) Aquifer

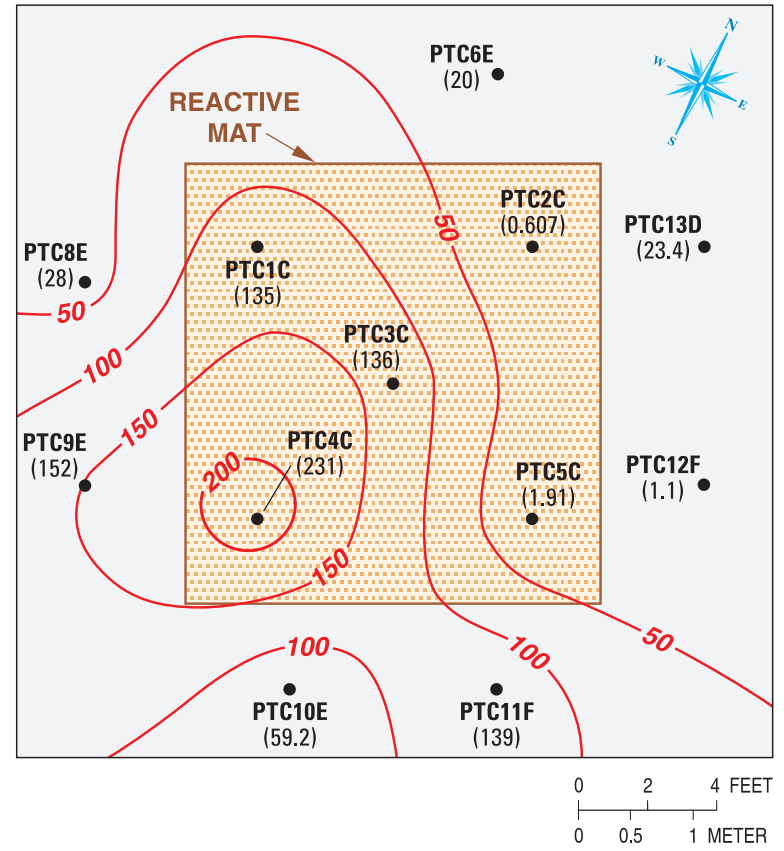

(B) Wetland sediments 8 feet below land surface

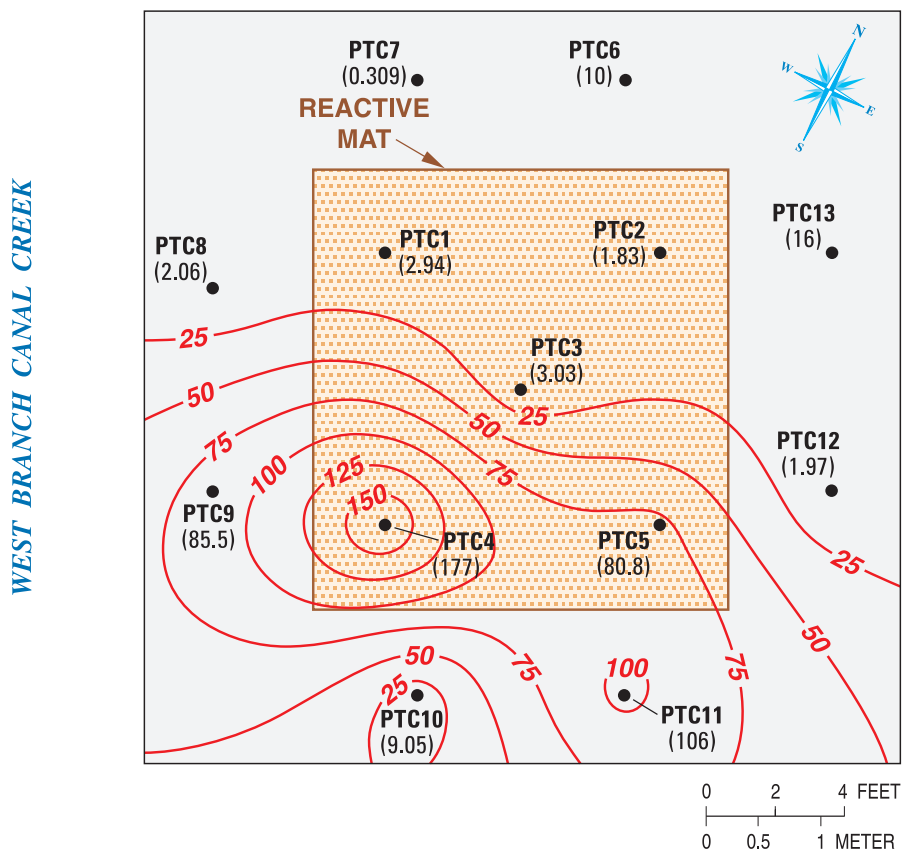

(C) Wetland sediments 5 feet below land surface

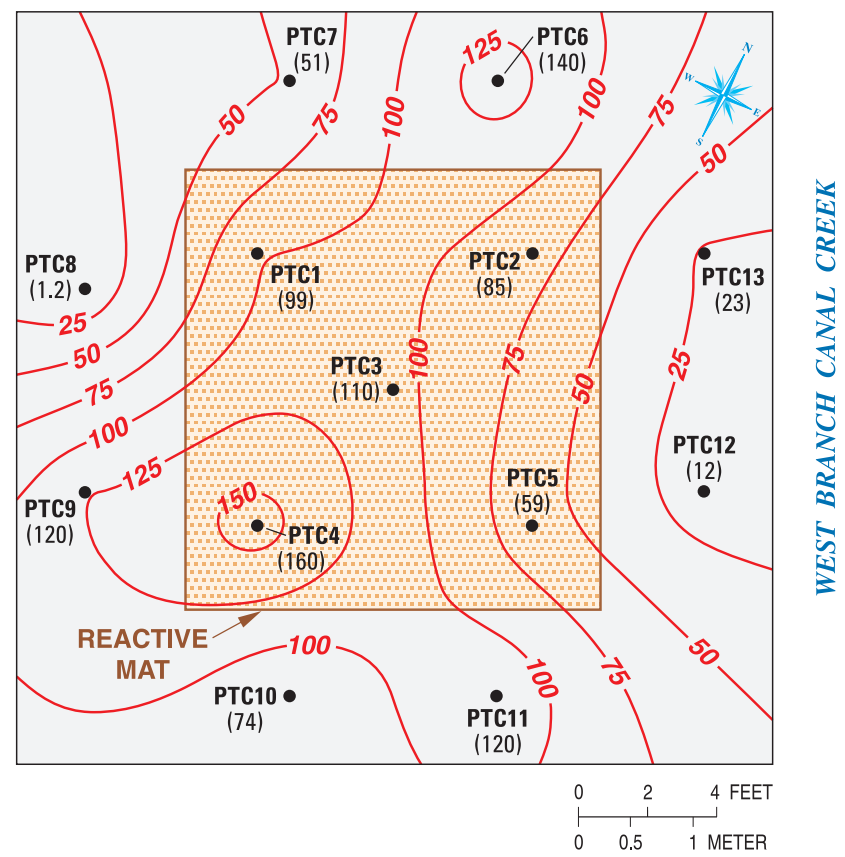

\section{EXPLANATION}

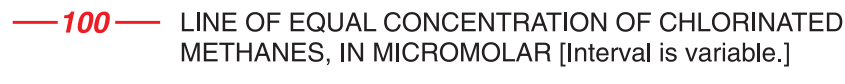

PTC9E

(152)
PIEZOMETER LOCATION AND IDENTIFIER (Number in parentheses is concentration, in micromolar.)

Figure 21. Planar distribution of chlorinated methanes below and within the reactive mat at the seep 3-4W pilot test area, West Branch Canal Creek, Aberdeen Proving Ground, Maryland, August 2005, (A) aquifer, $(B)$ wetland sediments 8 feet below land surface, (C) wetland sediments 5 feet below land surface, (D) PTN level, (E) PTBC level, and (F) PTBB level. 
(D) PTN level

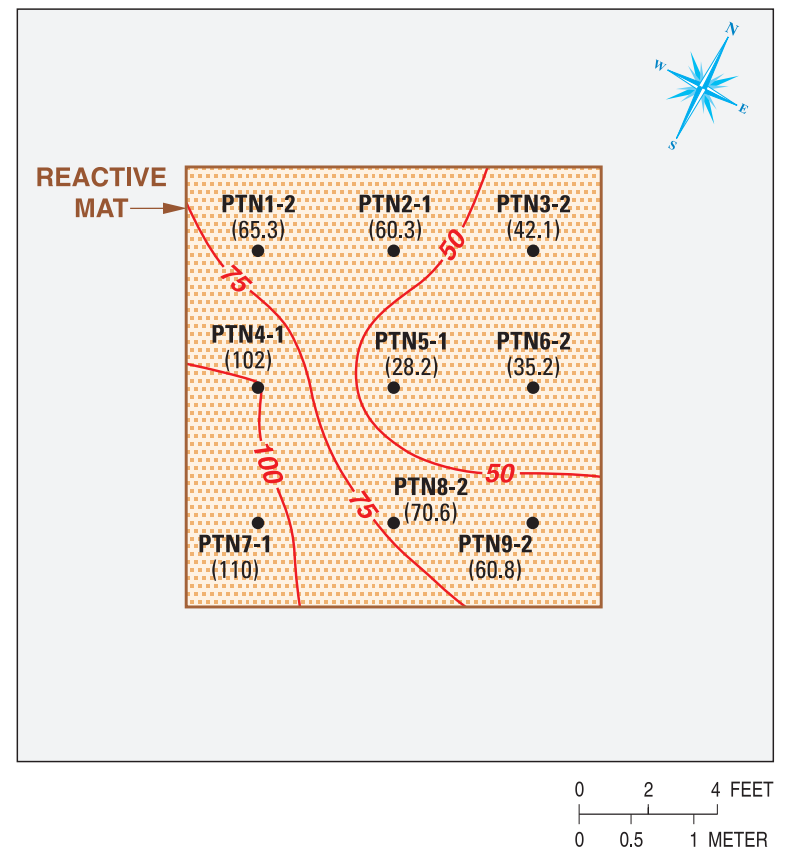

(E) PTBC level

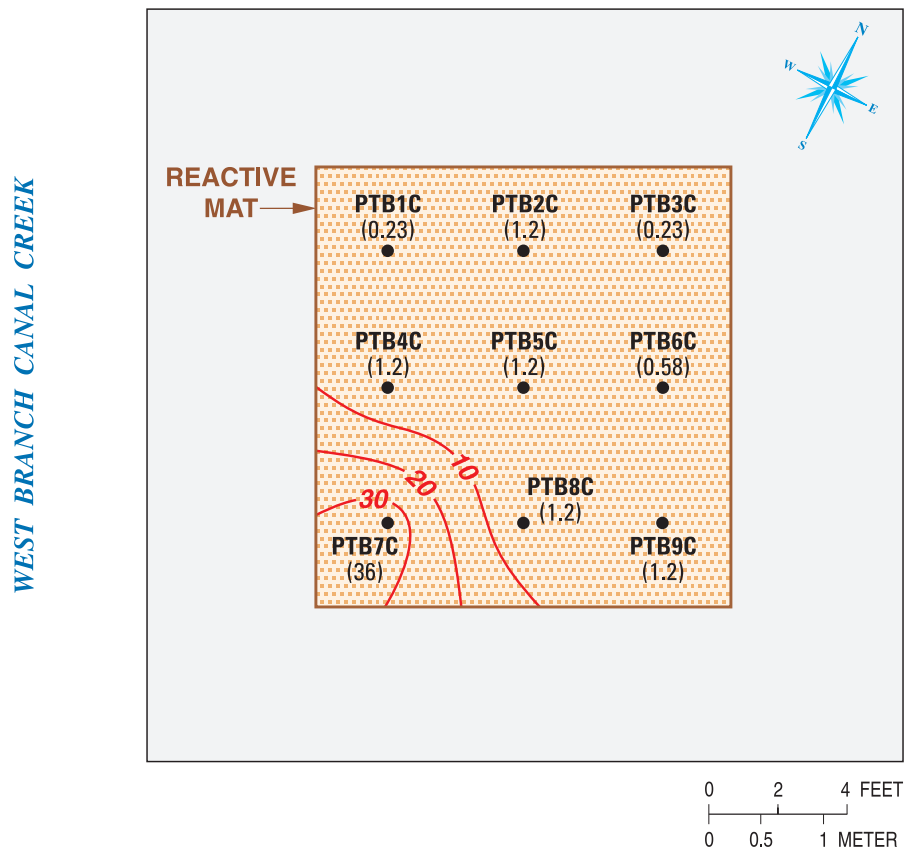

(F) PTBB level

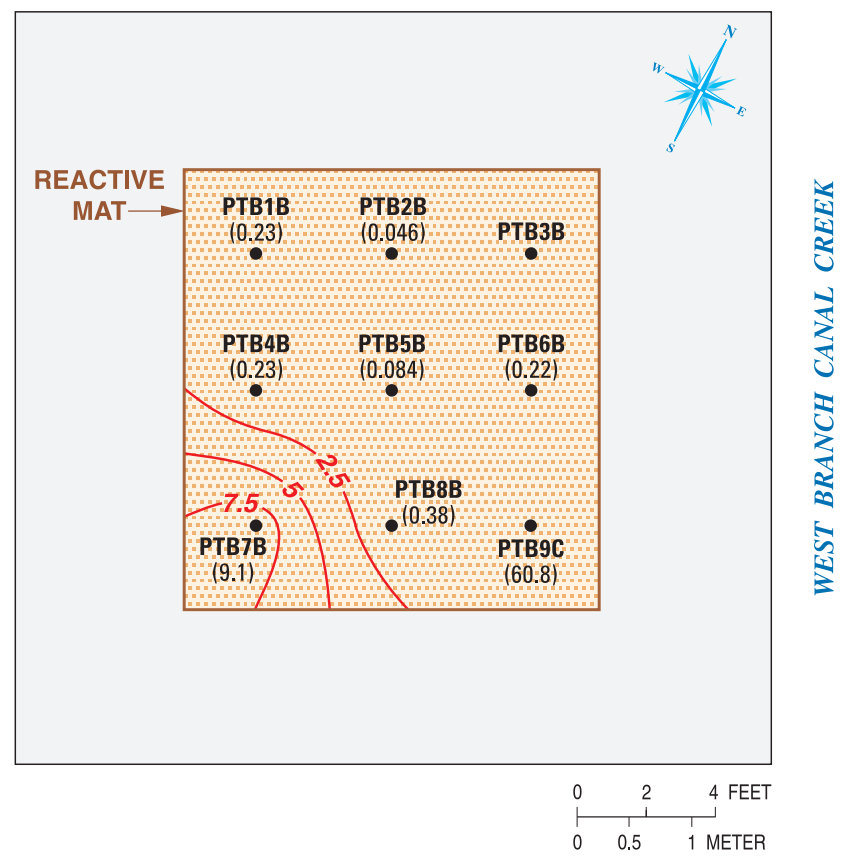

EXPLANATION
- 100 - LINE OF EQUAL CONCENTRATION OF CHLORINATED METHANES, IN MICROMOLAR [Interval is variable.]

PTN1-2

(65.3) MINI-POREWATER SAMPLER (PTN) OR MULTILEVEL DIFFUSION SAMPLER (PTB) LOCATION AND IDENTIFIER (Number in parentheses is concentration, in micromolar.)

Figure 21. Planar distribution of chlorinated methanes below and within the reactive mat at the seep 3-4W pilot test area, West Branch Canal Creek, Aberdeen Proving Ground, Maryland, August 2005, (A) aquifer, (B) wetland sediments 8 feet below land surface, (C) wetland sediments 5 feet below land surface, (D) PTN level, (E) PTBC level, and (F) PTBB level.—Continued 
(A) Wetland sediments 5 feet below land surface

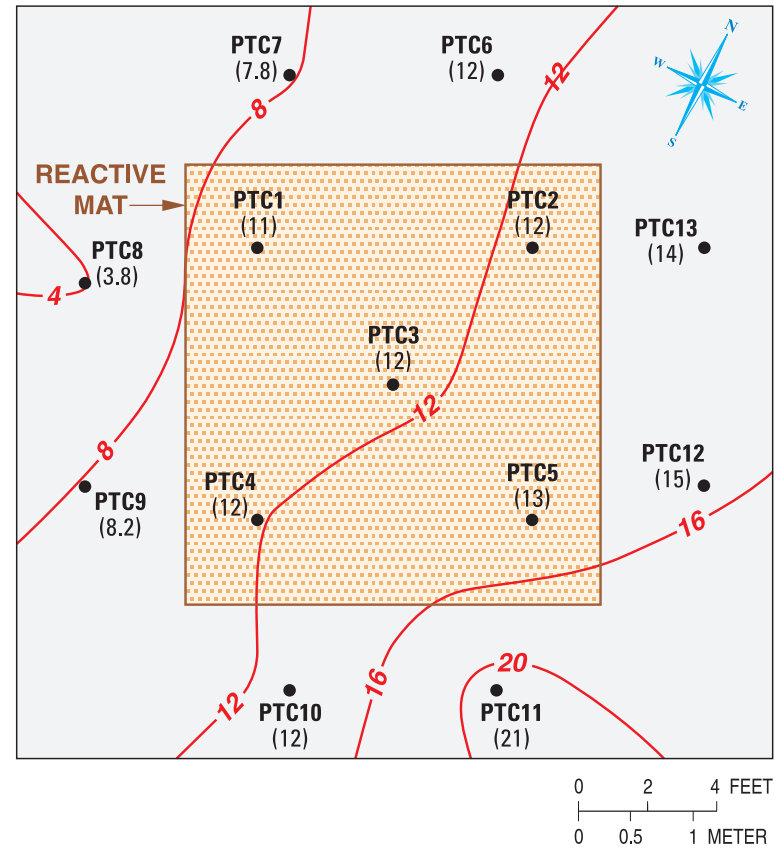

(B) PTN level

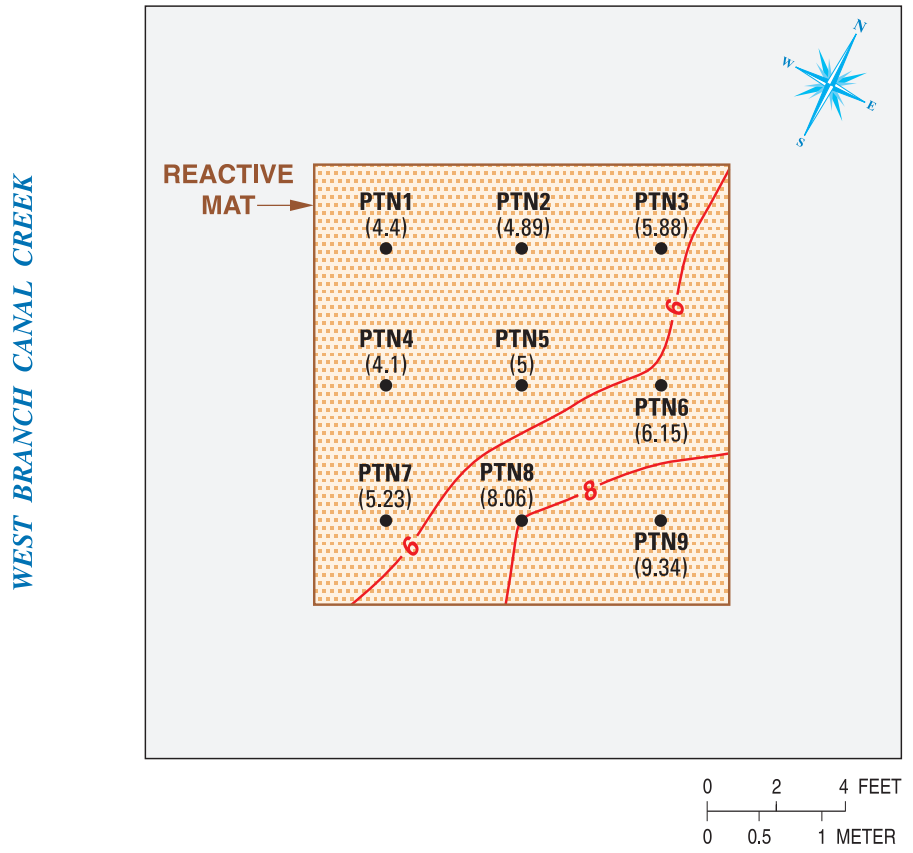

(C) PTBB level

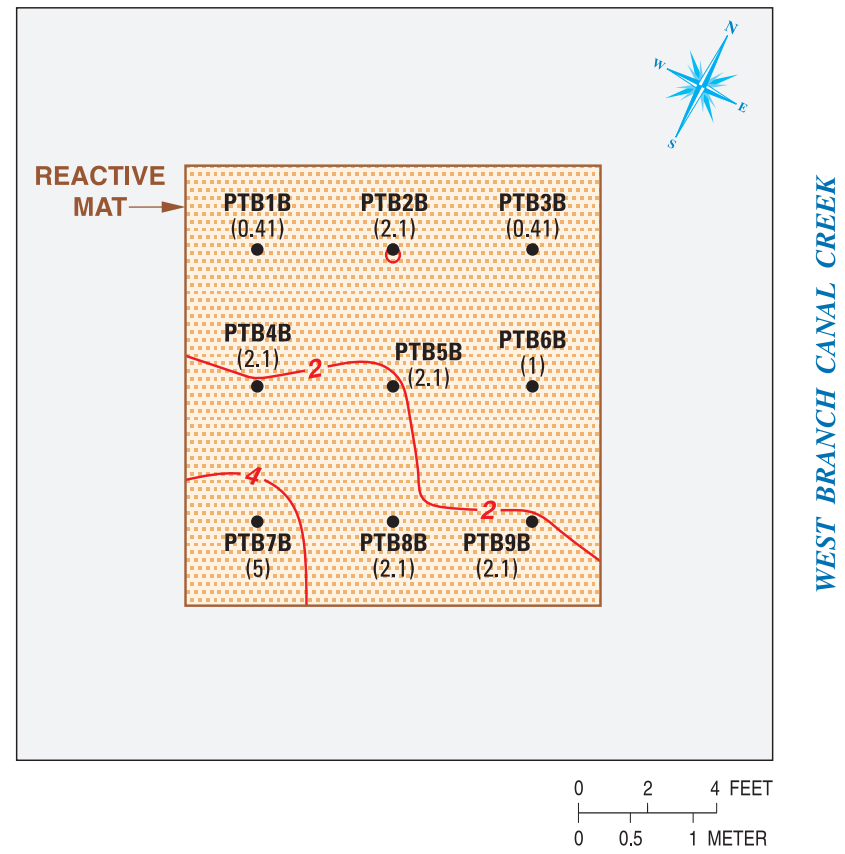

\section{EXPLANATION}

PTN1

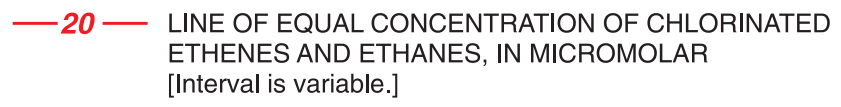

(4.4) PIEZOMETER (PTC), MINI-POREWATER SAMPLER (PTN), OR MULTILEVEL DIFFUSION SAMPLER (PTB) LOCATION AND IDENTIFIER (Number in parentheses is concentration, in micromolar.)

Figure 22. Planar distribution of chlorinated ethenes and ethanes below and within the reactive mat at the seep 3-4W pilot test area, West Branch Canal Creek, Aberdeen Proving Ground, Maryland, August 2005, (A) wetland sediments 5 feet below land surface, (B) PTN level, and (C) PTBB level. 

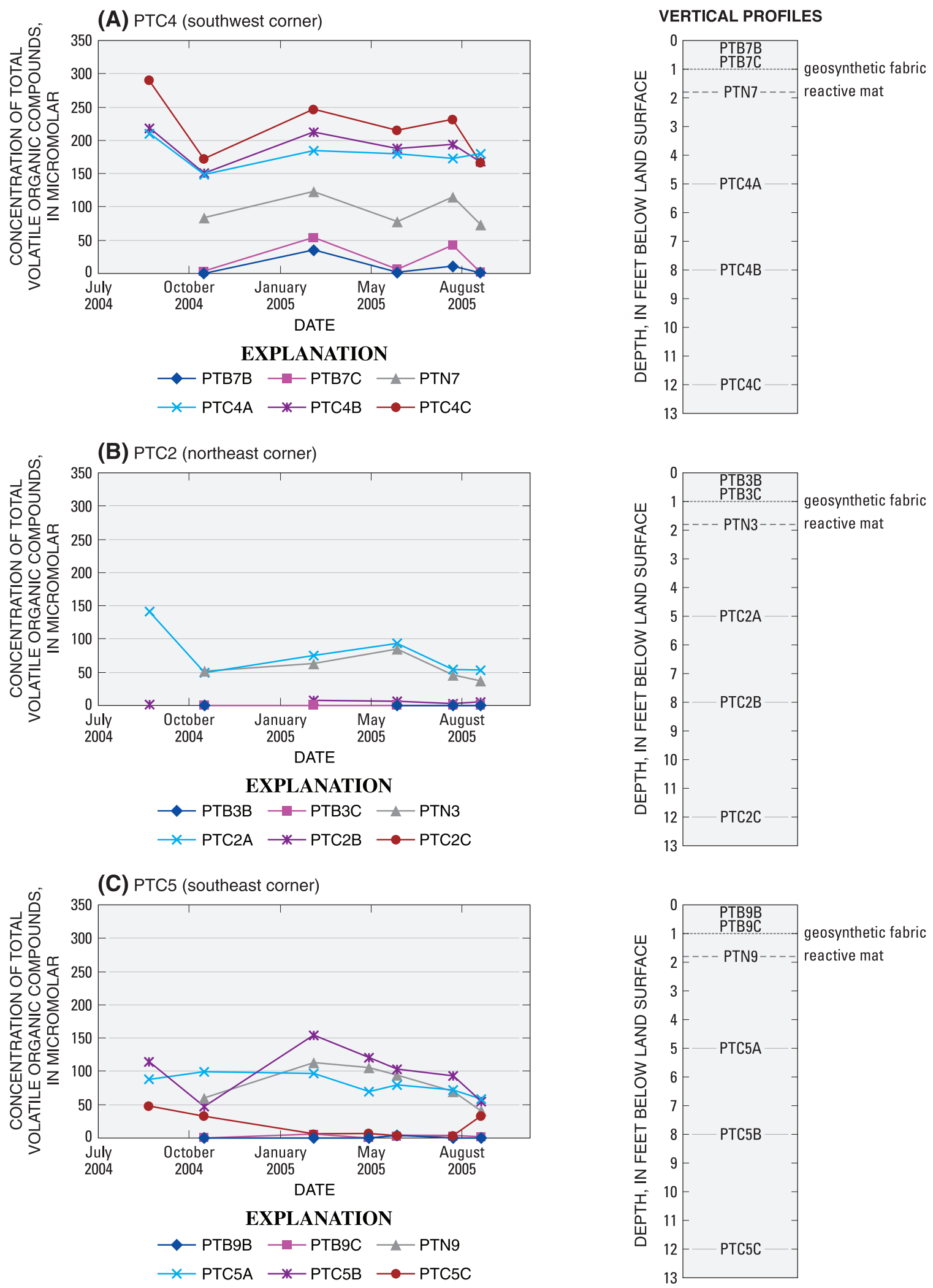

Figure 23. Vertical distribution of total chlorinated volatile organic compounds below and within the reactive mat at the seep 3-4W pilot test area, West Branch Canal Creek, Aberdeen Proving Ground, Maryland, August 2004-September 2005, (A) PTC4 (southwest corner), (B) PTC2 (northeast corner), and (C) PTC5 (southeast corner). 

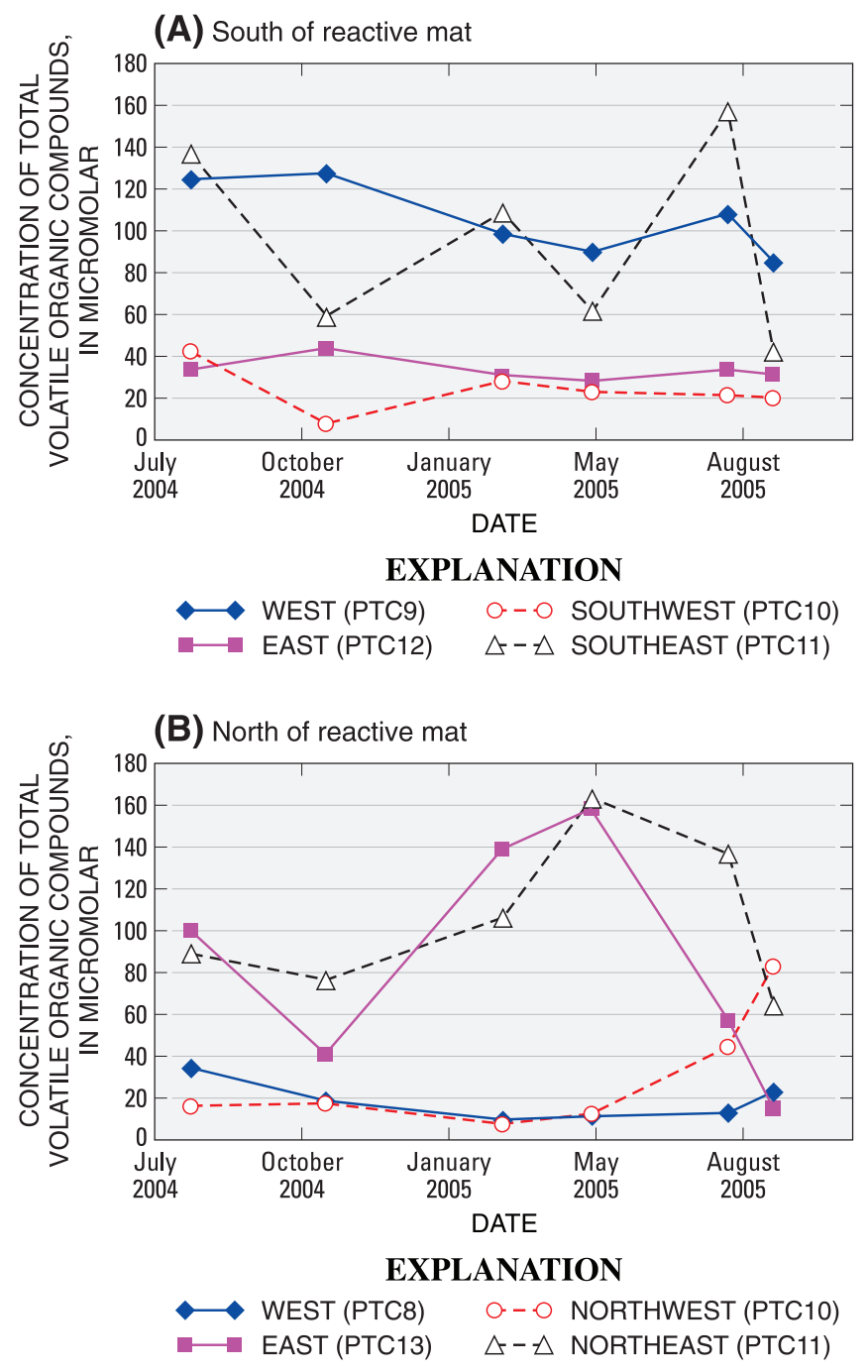

Figure 24. Total chlorinated volatile organic compounds in selected perimeter piezometers at the seep 3-4W pilot test area, West Branch Canal Creek, Aberdeen Proving Ground, Maryland, $(A)$ south and $(B)$ north of reactive mat.

of the mat, median groundwater elevation in piezometers screened in wetland sediments from 3 to $5 \mathrm{ft}$ bls showed a slight decrease to no change (table 10) when compared to preinstallation groundwater elevations. The variation between the values was largely within the standard deviation of groundwater elevation measurements (table 10). Similarly, at high tide, median values were slightly greater than pre-installation values; however, the standard deviation was consistently greater at high tide encompassing much of the observable variation in the median values (table 10).
Both vertical and horizontal hydraulic gradients in the vicinity of the reactive mat were estimated using groundwaterlevel data and then compared to pre-installation conditions in the same area. Vertical hydraulic gradients were calculated for seven piezometer clusters screened in the top of the aquifer and shallow ( 3 to $5 \mathrm{ft}$ bls) wetland sediments. No variation in vertical hydraulic gradients was observed between low and high tides, with mean vertical hydraulic gradients ranging from 0.20 to $0.26 \mathrm{ft} / \mathrm{ft}$, which is consistent with pre-installation calculations and those reported in Majcher and others (2007). Horizontal hydraulic gradients remained at least one to two orders of magnitude lower than those calculated in the vertical direction. The lack of an observable increase in groundwater elevation in shallow wetland piezometers and vertical gradients surrounding the mat indicated that the mat installation did not result in increased hydraulic pressure in the perimeter wells.

\section{In-Mat Flow}

The presence of a geotextile layer prevented the installation of piezometers through and below the reactive mat. Alternate methods used to assess and quantify flow through the mat included a potentiomanometer, seepage meters, and TIR imaging.

In December 2004, a potentiomanometer was used to assess the difference in hydraulic head between the surface water and porewater within the reactive mat (at location PTB5), and northeast of the mat boundary within the wetland sediments at similar depths and tide stages. The hydraulic head measured in the mat materials was greater than surfacewater elevation and increased with decreasing surface-water stage. The magnitude of hydraulic head difference between porewater and surface water was greater in the mat materials compared to the wetland sediments outside the mat at the same tidal stage. These measurements indicated a preferential flow through the mat compared with flow through the wetland sediments outside the mat boundary.

In July-August 2005, groundwater discharge within and outside of the mat was measured using a series of seepage meters to confirm vertical discharge through the mat during various stages of the tidal cycle, and to compare discharge with pre-installation conditions described in Majcher and others (2007). Meters were seated and measurements made within surrounding wetland sediments immediately to the north of the mat and along the former west and east shoring walls (mat boundary) toward the southern edge of the mat. Seepage flux to the north and west of the mat was similar, with some periods of recharge (negative seepage flux into sediments) and discharge (positive seepage flux out of the sediments). In these areas, the magnitude of seepage (about $2 \mathrm{ft} / \mathrm{yr}$ ) was an order of magnitude less than the geometric mean flux of $19 \mathrm{ft} / \mathrm{yr}$ for seep 3-4W and was comparable to the minimum values of seepage detected within seep 3-4W (Majcher and others, 2007). The values were still greater, however, than reported seepage flux of 0.3 to $0.9 \mathrm{ft} / \mathrm{yr}$ that was 
(A) PTC4/PTB7 chloroethenes and chloroethanes, March 2005

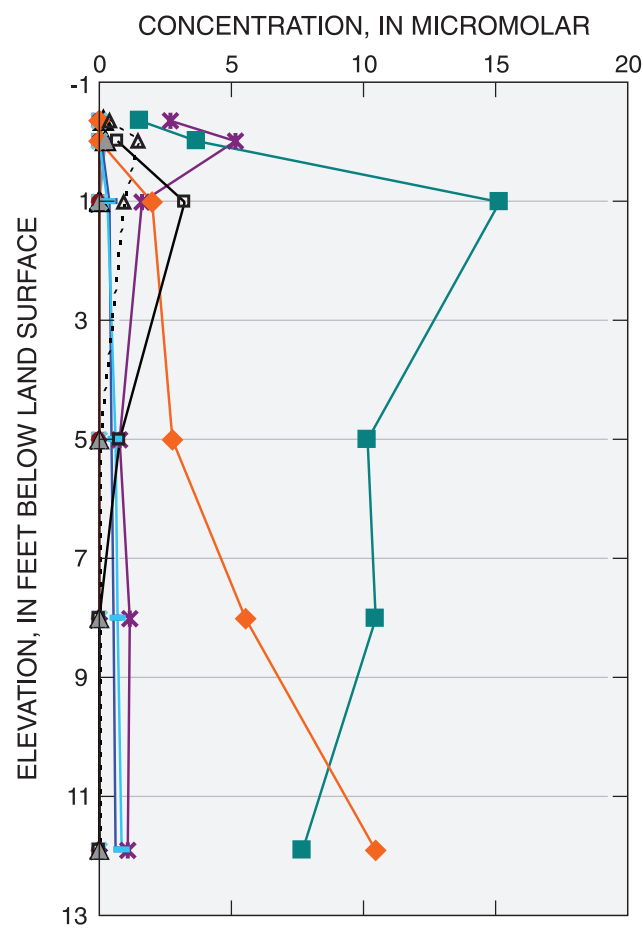

(C) PTC4/PTB7 chloroethenes and chloroethanes, June 2005 CONCENTRATION, IN MICROMOLAR

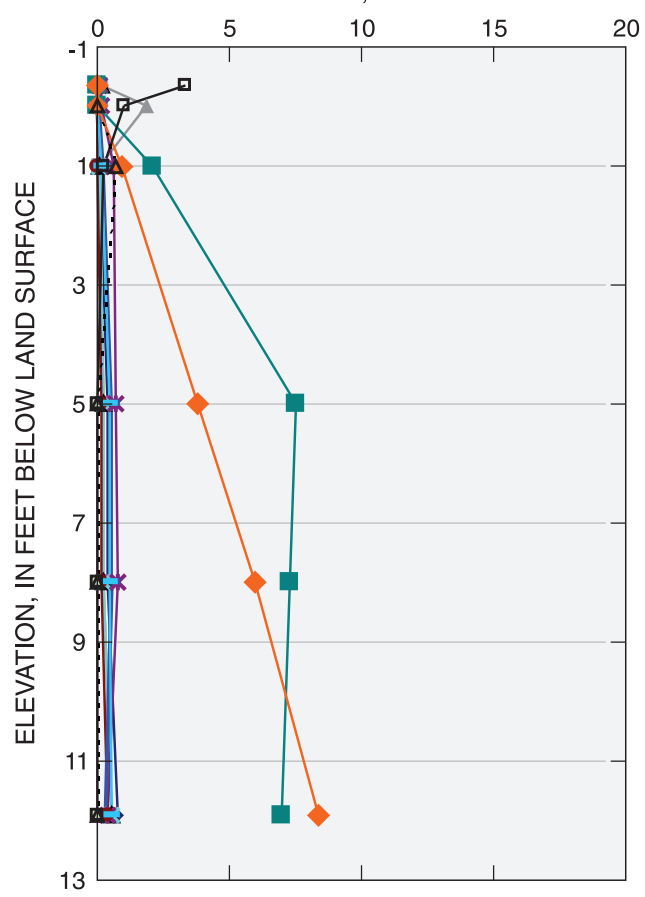

(B) PTC4/PTB7 chloromethanes, March 2005 CONCENTRATION, IN MICROMOLAR

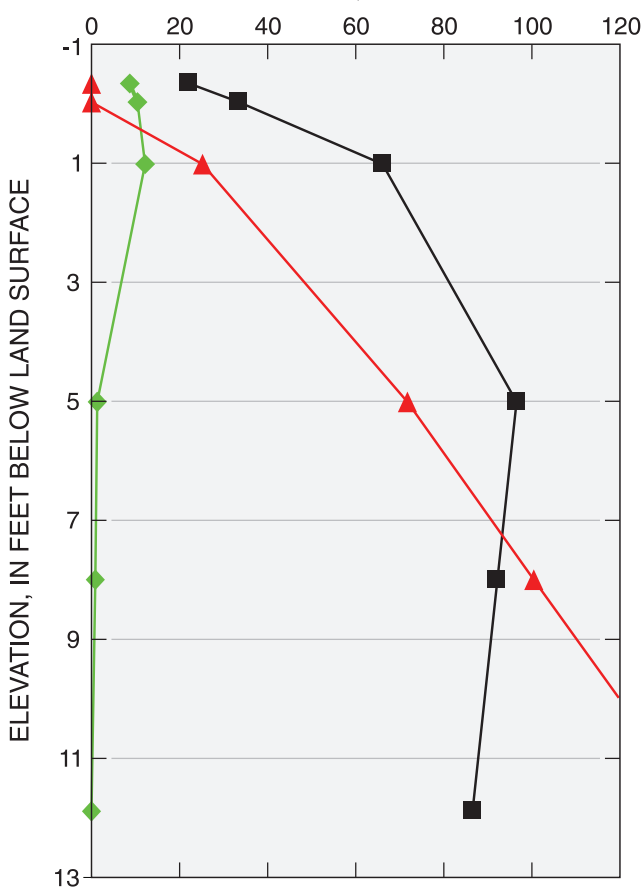

(D) PTC4/PTB7 chloromethanes, June 2005 CONCENTRATION, IN MICROMOLAR

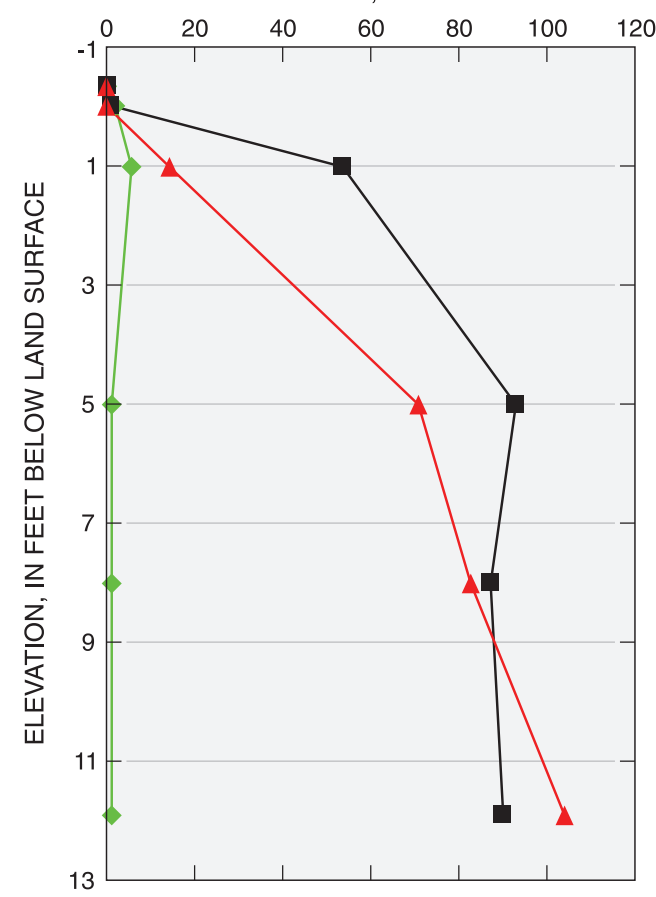

\section{EXPLANATION}

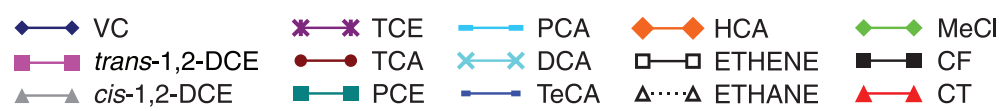

Figure 25. Vertical distribution of selected chlorinated volatile organic compounds below and within the reactive mat in the spring and summer at the seep 3-4W pilot test area site PTC4/PTB7, West Branch Canal Creek, Aberdeen Proving Ground, Maryland, (A) chloroethenes and chloroethanes, March 2005, (B) chloromethanes, March 2005, $(C)$ chloroethenes and chloroethanes, June 2005, and (D) chloromethanes, June 2005. 
Table 9. Estimated mass removal of chloromethanes and the sum of chloroethanes and chloroethenes through the zero-valent iron (ZVI) mix and organic mix zones in the seep 3-4W reactive mat pilot test area, West Branch Canal Creek, Aberdeen Proving Ground, Maryland, November 2004-August 2005.

\begin{tabular}{c|c|c|}
\hline $\begin{array}{c}\text { Sampling } \\
\text { event }\end{array}$ & $\begin{array}{c}\text { Percent mass removal } \\
\text { of chloromethanes } \\
\text { PTBC }^{1}\end{array}$ & $\begin{array}{c}\text { Chloroethanes plus } \\
\text { chloroethenes } \\
\text { PTBB }^{2}\end{array}$ \\
\hline November 2004 & $97.9 / 98$ & $99.9 / 99.6$ \\
\hline March 2005 & $82.1 / 88.1$ & $98.1 / 98.5$ \\
\hline May 2005 & $90.8 / 85$ & $93.7 / 87.1$ \\
\hline June 2005 & $99.4 / 90.1$ & $99.4 / 92.6$ \\
\hline August 2005 & $92.5 / 67.4$ & $98.2 / 94$ \\
\hline
\end{tabular}

${ }^{1}$ top of ZVI-organic zone

${ }^{2}$ middle of organic zone

typical of non-seep areas of the wetland (Majcher and others, 2007). Seepage flux along the eastern mat boundary (37 ft/yr) was similar to or greater than seepage flux measured in areas of maximum discharge prior to mat installation, a ten-fold increase over the areas to the north and west.

Within the mat, meters were positioned in the southwest and east-central areas. Seepage measurements in both areas were highly variable, with periods of recharge and discharge. Measurements of seepage discharge within the mat were similar to measurements along the north and west areas surrounding the mat, with a geometric mean flux ranging from 0.8 to $1.4 \mathrm{ft} / \mathrm{yr}$.

Measurements of seepage recorded along the southeast boundary of the reactive mat and decreased seepage flux within the mat area may be attributable to a combination of several factors. First, one design goal of the geotextile was to create laminar flow throughout the treatment area. Normalization of flow appears to have occurred, resulting in an overall reduction in flux. Second, the range of seepage measured in most meters was near the method detection limit, thus reducing accuracy and sensitivity. Finally, the observed reduction in flux and increase in recharge may also have resulted from the increased head requirement to reach the top of the mat, which was constructed about $10 \mathrm{in}$. above land surface in the mat center. Whereas the hydraulic head differences appeared to be substantial enough for flow to reach the surface prior to installation of the mat, it is possible that the normalization of flow throughout the mat footprint may have reduced the head difference enough to inhibit constant discharge under all tidal conditions. Due to the gradual slope of the area and the gradual horizontal gradient in the direction of the creek, some part of flow from the above-grade section of the reactive mat may be directed horizontally to the eastern boundary of the mat area.

Further evidence of more normalized flow was apparent in the aerial TIR flight of the seep area conducted during winter 2004. The reactive mat area did not appear to be warmer than surrounding sediments as it had in previous flights, prior to installation (fig. 28a). No new seep areas were apparent in the wetland sediments surrounding the mat (fig. 28a); however, previously observed seep areas in the vicinity of 3-4W were consistent with previous flights (Majcher and others, 2007). Consistency with previous studies and the lack of thermal contrast in the mat area indicated groundwater was not bypassing the reactive mat, at least at the time of observation. The seepage and TIR results implied that the area of maximum seepage at 3-4W was largely encompassed by the footprint of the mat. The possible reduction in flux and slight discharge towards the eastern boundary during low tide in areas above grade would result in a beneficially longer residence (treatment) time in the reactive mat.

Due to the high dosing of chitin and compost in the reactive mat, methane concentrations had increased substantially by the first monitoring event in November 2004 and may have impacted the mat hydraulics. The sharp concentration gradient of methane over a narrow thickness may have delayed the establishment of more homogeneous hydrologic conditions due to the biogenic gas generated immediately following installation of the mat (Beckwith and Baird, 2001; Himmelheber and others, 2007). At the time of installation, the mat pore space was not entirely saturated with wetland sediment porewater, but likely contained a mixture of porewater, biogenic gas, and surface water. The immediate production of biogenic gas may have resulted in a reduction of hydraulic conductivity (Beckwith and Baird, 2001). A reduction in methane concentration following the winter months resulted in a more gradual increase in methane concentration, and likely more consistent hydrologic conditions in the reactive mat. A better understanding of the effects of biogenic gas in the mat would be gained from the collection of intact cores.

\section{Volatile Organic Compounds in Shallow Porewater as Tracers in Seep Areas}

In focused seep areas such as seep 3-4W, VOCs were shown to be largely conserved from near sources in the aquifer to the wetland surface, making them useful tracers of advective groundwater flow (Majcher and others, 2007). PDSs were shown to be effective, economical tools to identify contaminated seeps through the presence or absence of VOCs and methane in the upper wetland sediments (Majcher and others, 2007). Sediments in seep areas nearby the mat were characterized in April 2005 using PDSs and these results were used to assess the possible divergence of flow (and contaminants) to these pre-existing seeps. The PDS investigation included the coves along the western bank north of the reactive mat pilot 
(A) Reactive mat surface elevation, October 2004

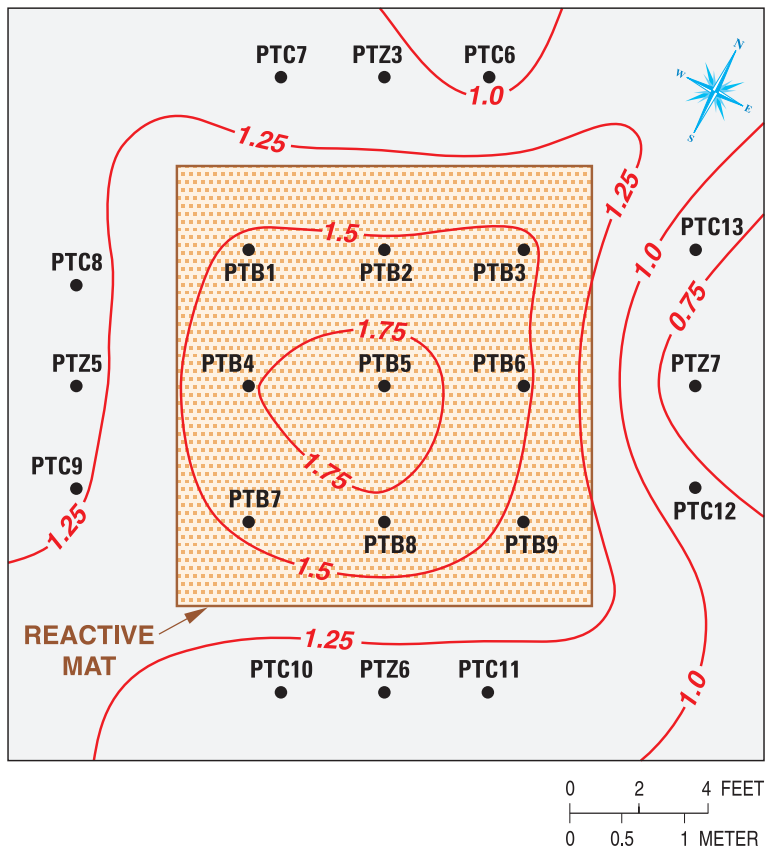

(B) Reactive mat surface elevation, March 2005

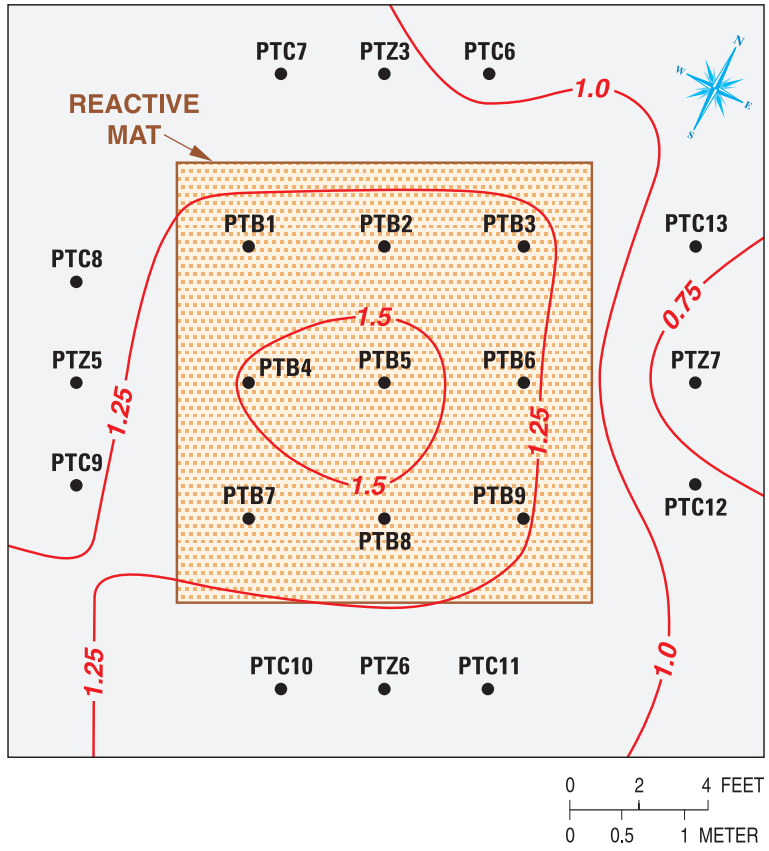

EXPLANATION

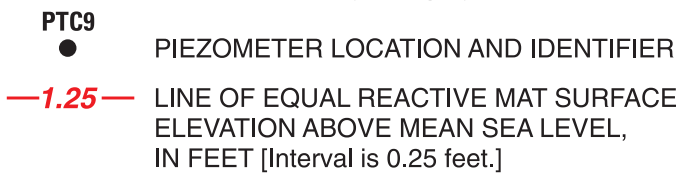

Figure 26. Surface elevations of reactive mat and surrounding area at seep $3-4 \mathrm{~W}$ reactive mat pilot test area, West Branch Canal Creek, Aberdeen Proving Ground, Maryland, (A) October 2004 and (B) March 2005. test, the creek channel to the east of seep 3-4W, and previously identified seep area 3-3E (Majcher and others, 2007)

(fig. 1b). VOCs were found in concentrations below their detection limits in northern inlet areas on the western side of the creek channel and in a seep along the eastern creek bank (3-3E), consistent with previous investigations of these areas (Majcher and others, 2007).

Any local shift in contaminant transport likely would be most apparent within the untreated parts of seep 3-4W. PDS samples that were collected immediately north, south, and along the boundary of the reactive mat had VOC concentrations similar to those measured during fall 2002, fall 2003, and spring 2004 (Majcher and others, 2007) in wetland sediments along the western bank of the creek (fig. 28b). VOCs were detected between the western bank and the center of the creek channel; however, these VOCs were primarily daughter compounds including TCE, cis-1,2DCE, VC, and CF and methylene chloride. The presence of these daughter compounds is consistent with the deeper transport of parent VOCs within the aquifer to the western side of the creek with an upward and slight easterly migration of VOCs in the upper wetland sediments (Majcher and others, 2007).

Vertical cross sections of chloromethane VOC isoconcentrations, which span the western vertical plane from south to north $\left(Y^{\prime} Y^{\prime}\right)$ and the southern vertical plane from west to east (Z-Z'), were used to assess advective flow below and surrounding the reactive mat (figs. 5a, 29, and 30). In areas where the greatest discharge occurs, advection or macropore flow will control the transport of the VOCs, whereas in areas of lesser discharge, a combination of advection and diffusion across a steep concentration gradient will control VOC transport (Lorah, Spencer, and McGinty, 2005; Majcher and others, 2007). Along cross-section Z-Z', a decline in concentrations of chloromethanes was observed to the north and south of the PTC4 profile (fig. 29), where the maximum concentrations of chloromethanes were mainly focused during all monitoring events (Appendixes 3A,B). A greater proportion of the chloromethane mass appears to be conserved in a vertical direction directly below the mat, as evident in the steeper concentration gradient in the lateral direction compared to the vertical direction (fig. 29). The concentration gradient did not appear to increase with time from mat installation at a depth of $3 \mathrm{ft}$ bls, except during August-September 2005, when increased concentrations also were detected in nearby PTC1 to the north. A corresponding increase in total VOCs is apparent in the northwest perimeter piezometer PTC7 during this timeframe, predominantly due to an increase in chloromethanes (figs. 29, 31a). More variability immediately below the reactive mat was observed for chloroethenes and ethanes over time along section Z-Z'; however, the general VOC isoconcentration pattern, particularly from PTC4 to PTN7, was similar to the pattern for chloromethanes.

Along cross-section Y-Y', chloromethane concentrations decreased laterally from a maximum concentration along the wetland/aquifer boundary at PTC4 to the west and east, where isoconcentrations extended beyond the western and eastern 
(A) Low tide (West)

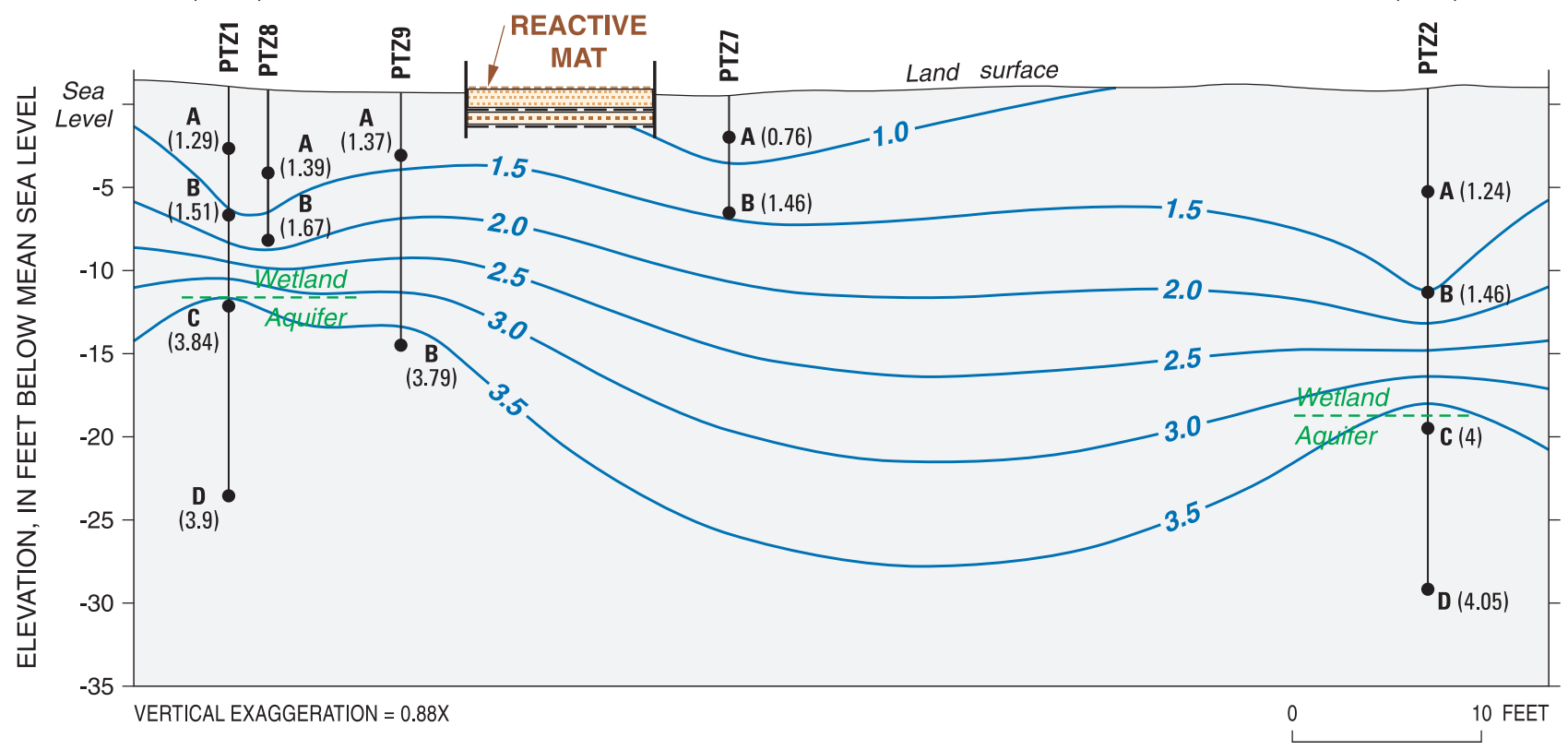

(B) $\quad \mathrm{E}$ Low tide (North)

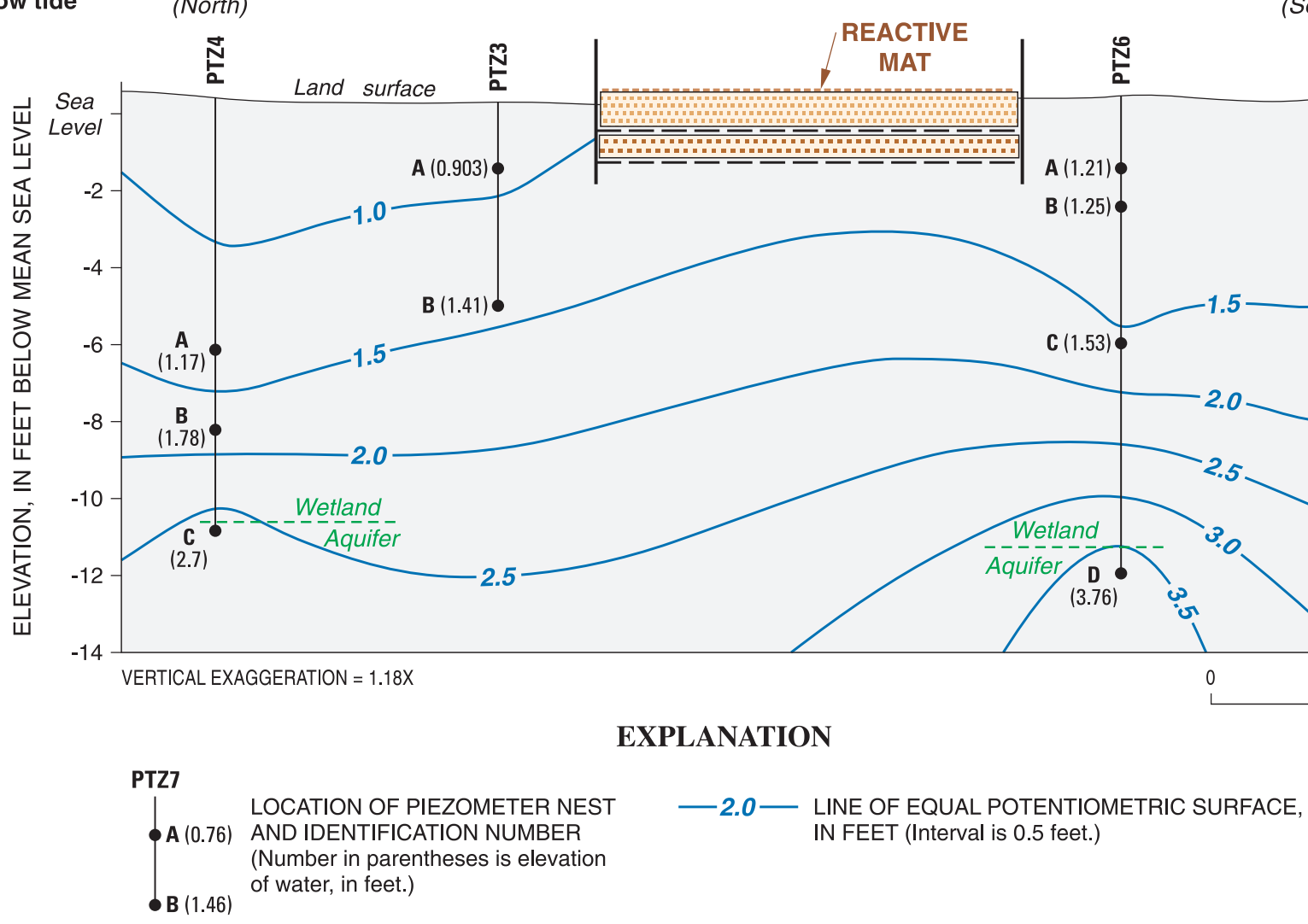

Figure 27. Vertical distribution of mean head elevation at low tide along two lines of section after reactive mat installation, West Branch Canal Creek, Aberdeen Proving Ground, Maryland, (A)D-D' and (B) E-E'. 
Table 10. Comparison of water-level elevations at low and high tide in selected piezometers before deployment of the reactive mat (August-September 2004) to the mean water-level elevations measured after deployment (November 2004-September 2005), seep 3-4W pilot test area, West Branch Canal Creek, Aberdeen Proving Ground, Maryland.

[ft, feet; --, not measured]

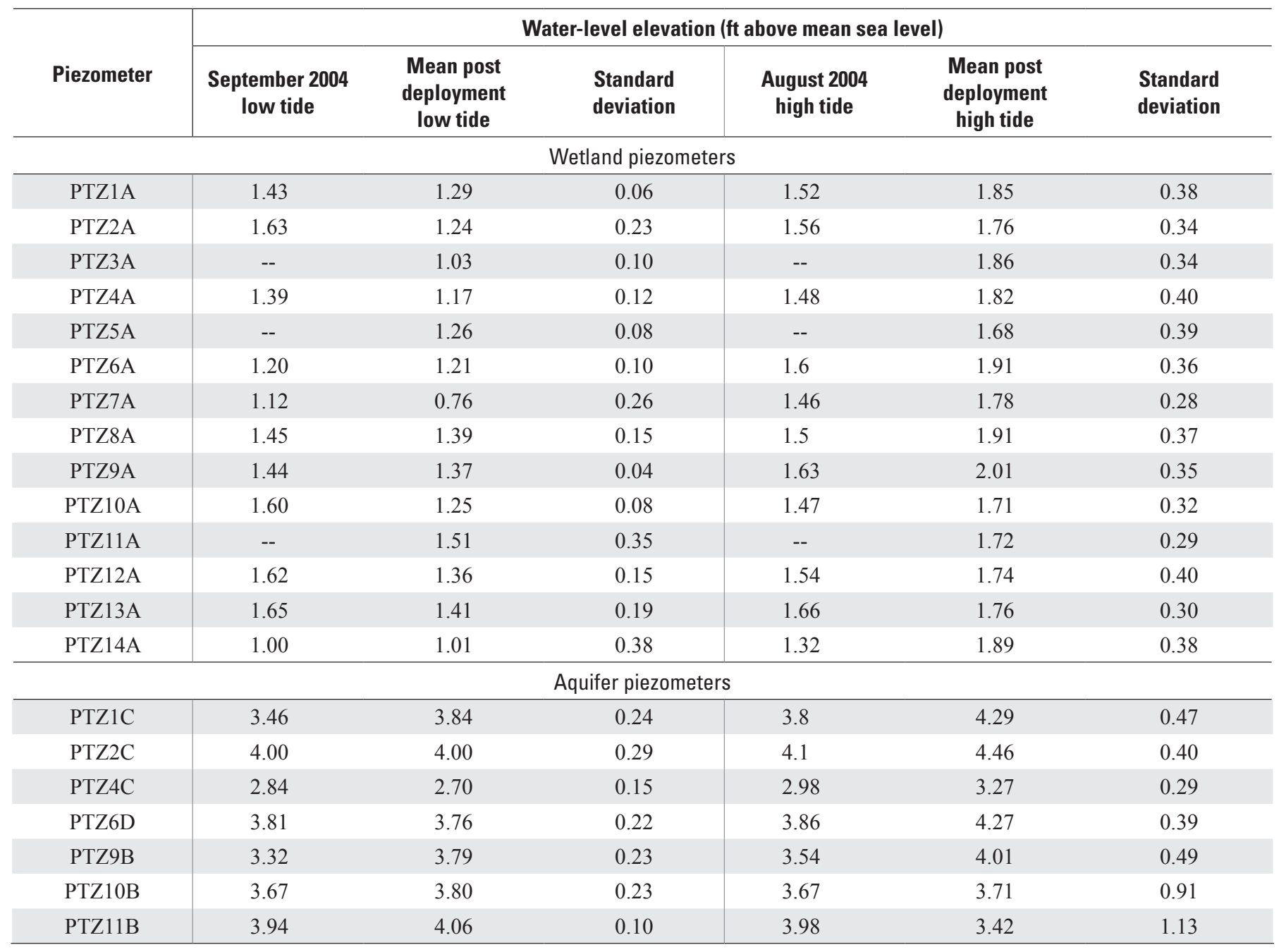


mat boundary during all monitoring events as evident in August 2005 (fig. 30); and this was consistent with conditions prior to the installation of the mat. Similar to the Z-Z' cross section, isoconcentrations indicated a more rapid decrease in VOC concentrations in the lateral direction compared to the vertical direction, consistent with the apparent differences in rates of flow in these two directions. Observations of total VOCs over time (including prior to mat installation) in perimeter wells PTC9 (to the west) and PTC12 (to the east) from 3 to $5 \mathrm{ft}$ bls indicated that the mat did not redirect contaminated porewater outside of the mat area (fig. 31b). The lack of increased VOC concentrations in porewater to the east of the mat (PTC12A), despite increased seepage in this area, indicated no bypassing of water under the mat in an easterly direction.

\section{Water Quality}

Groundwater and surface water were sampled throughout the monitoring period to determine if the reactive mat had any measurable effects on water quality. Groundwater and wetland porewater immediately below and at shallow depths surrounding the reactive mat were sampled during the monitoring period for $\mathrm{pH}$, specific conductance, nutrients, major ions, and dissolved metals. Porewater from within the reactive mat was not sampled due to the passive nature of sampling devices and resulting small volumes available from these samplers.

$\mathrm{pH}$ ranged from 3.6 to 4.0 throughout the monitoring period in both perimeter and under-mat piezometers at $3 \mathrm{ft}$ bls (fig. 32a). The $\mathrm{pH}$ in under-mat piezometers from 1 to $3 \mathrm{ft}$ bls was more variable than the perimeter piezometers, particularly at the $1 \mathrm{ft}$ bls level, ranging from 3.3 to 5.8 (fig. 32b). At $1 \mathrm{ft}$ bls, a slight overall increase in $\mathrm{pH}$ was measured, likely due to the close proximity to the ZVI zone of the reactive mat. Specific conductance followed a similar pattern with $\mathrm{pH}$ (figs. 32c,d). Below the reactive mat, the specific conductance was more variable than what was observed in the perimeter piezometers; however, most monitoring points followed similar patterns over the monitoring period. Values of specific conductance were within the range of those reported historically at West Branch Canal Creek (Lorah, Spencer, and McGinty, 2005). Variability in specific conductance is likely attributable to temporal changes rather than a change in water type as a result of mat installation.

Nutrients, ammonia, o-phosphate (as $\left.\mathrm{PO}_{4}\right)$, and nitrate $\left(\mathrm{N}\right.$ as $\mathrm{NO}_{3}$ ), consistently were near or below the detection limits prior to and throughout the monitoring period in the uppermost sampling interval of perimeter piezometers and under-mat piezometers following mat installation (Appendix 1). Some isolated detections of o-phosphate and nitrate were found under the reactive mat (PTC3A in March 2005 and PTC2A in May 2005), but these detections showed no spatial or temporal trends. These detections also may be a result of the warming of the sediments following the winter months, which results in increased microbial activity and possibly, increased nutrients in porewater (Lorah, Spencer, and

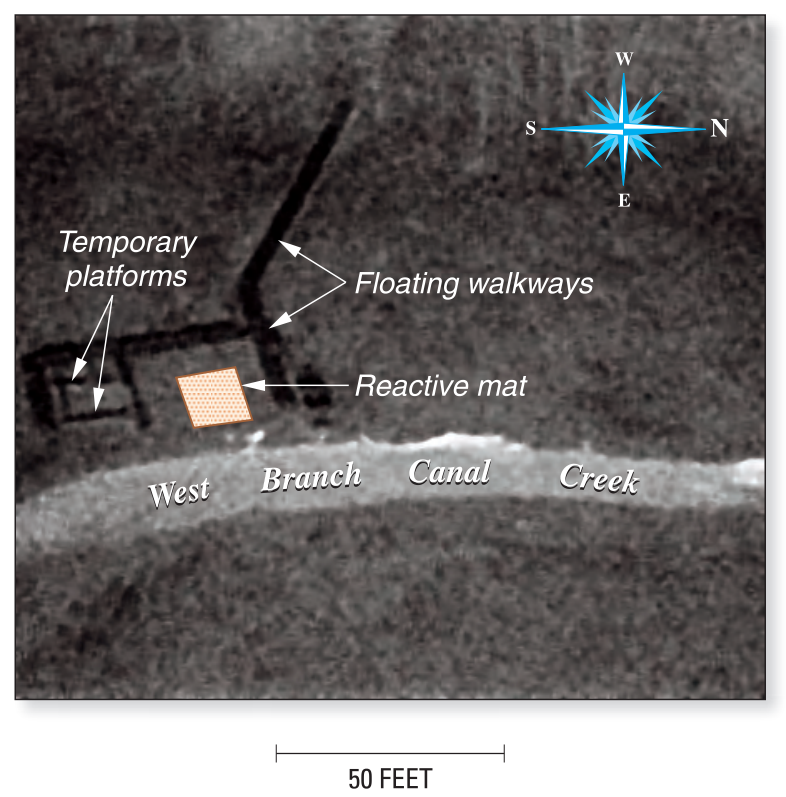

Figure 28a. Thermal infrared image of the seep 3-4W reactive mat pilot test area, West Branch Canal Creek, Aberdeen Proving Ground, Maryland, 2005.

McGinty, 2005). Similarly, some isolated detections of nutrients were measured in perimeter piezometers during various sampling events with maximum concentrations of ammonia, o-phosphate, and nitrate detected at $1.05,5.1$, and $0.75 \mathrm{mg} / \mathrm{L}$, respectively, during different sampling events from different piezometers.

Some dissolved metals and ions had the potential to increase nearby groundwater concentrations following mat installation due to $\mathrm{pH}$ or redox changes, as indicated by preinstallation SEP analysis. A slight increase in dissolved calcium concentrations was observed in the uppermost sampling interval of PTC3, possibly as a result of the elevated concentration of calcium found in the crab compost fraction of the reactive mat. Perimeter piezometers indicated variable concentrations of calcium, increasing over time in PTC6, PTC8, and PTC10, but remaining steady in PTC12. A slight increase also was observed in sodium concentrations from PTC3, PTC6, and PTC12 over the monitoring period.

Immediately below the reactive mat (PTC3A), arsenic, lead, and zinc slightly increased over the monitoring period, while mercury and nickel remained steady or decreased over time when compared to pre-installation concentrations (Appendix 2). Perimeter piezometers had stable to declining concentrations of dissolved metals. Aluminum and manganese, two metals without PECs, generally increased in concentration over time both below and around the reactive mat. 


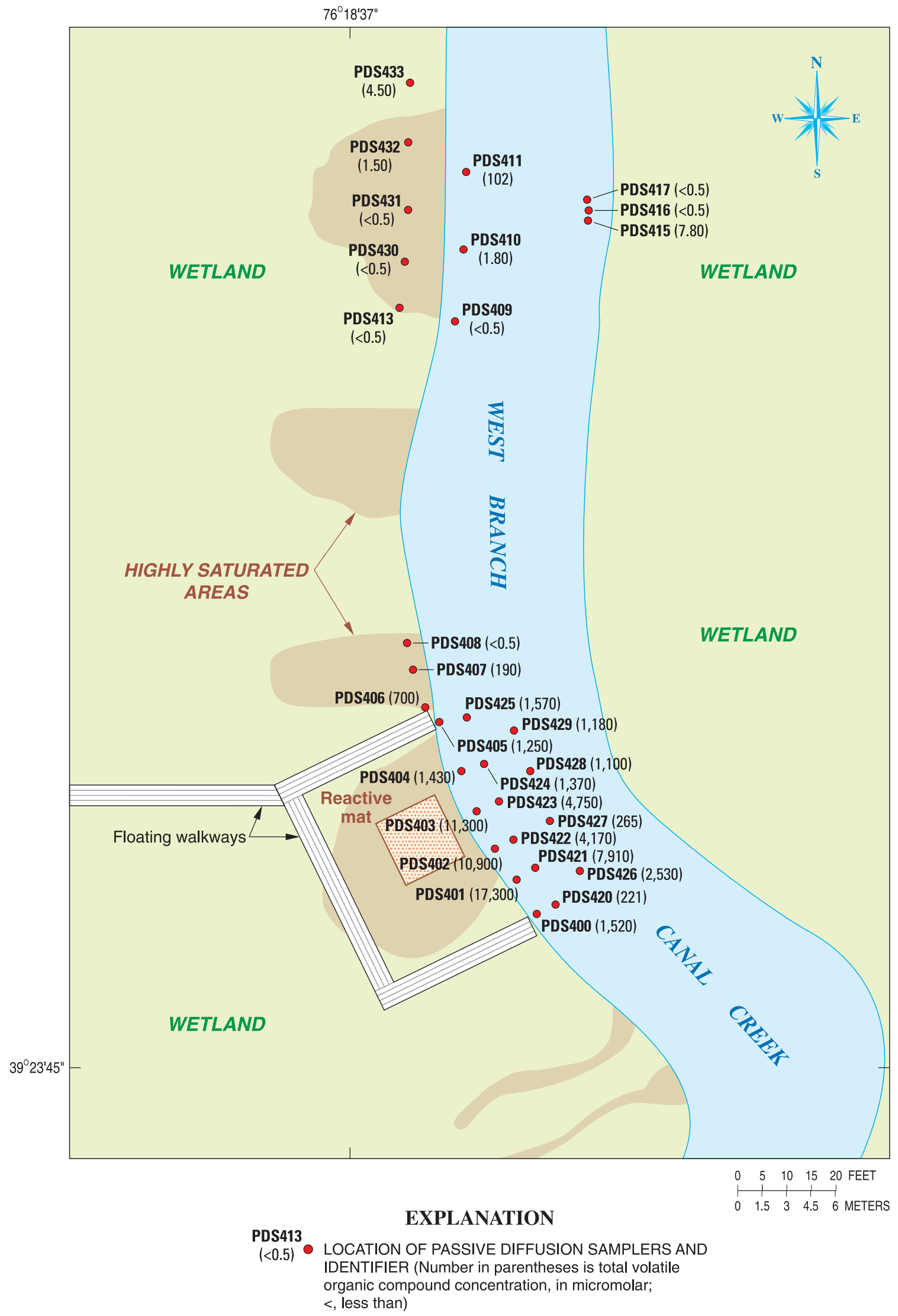

Figure 28b. Total volatile organic compound concentrations detected in passive diffusion samplers installed following thermal infrared imaging of the seep 3-4W reactive mat pilot test area, West Branch Canal Creek, Aberdeen Proving Ground, Maryland, 2005. 


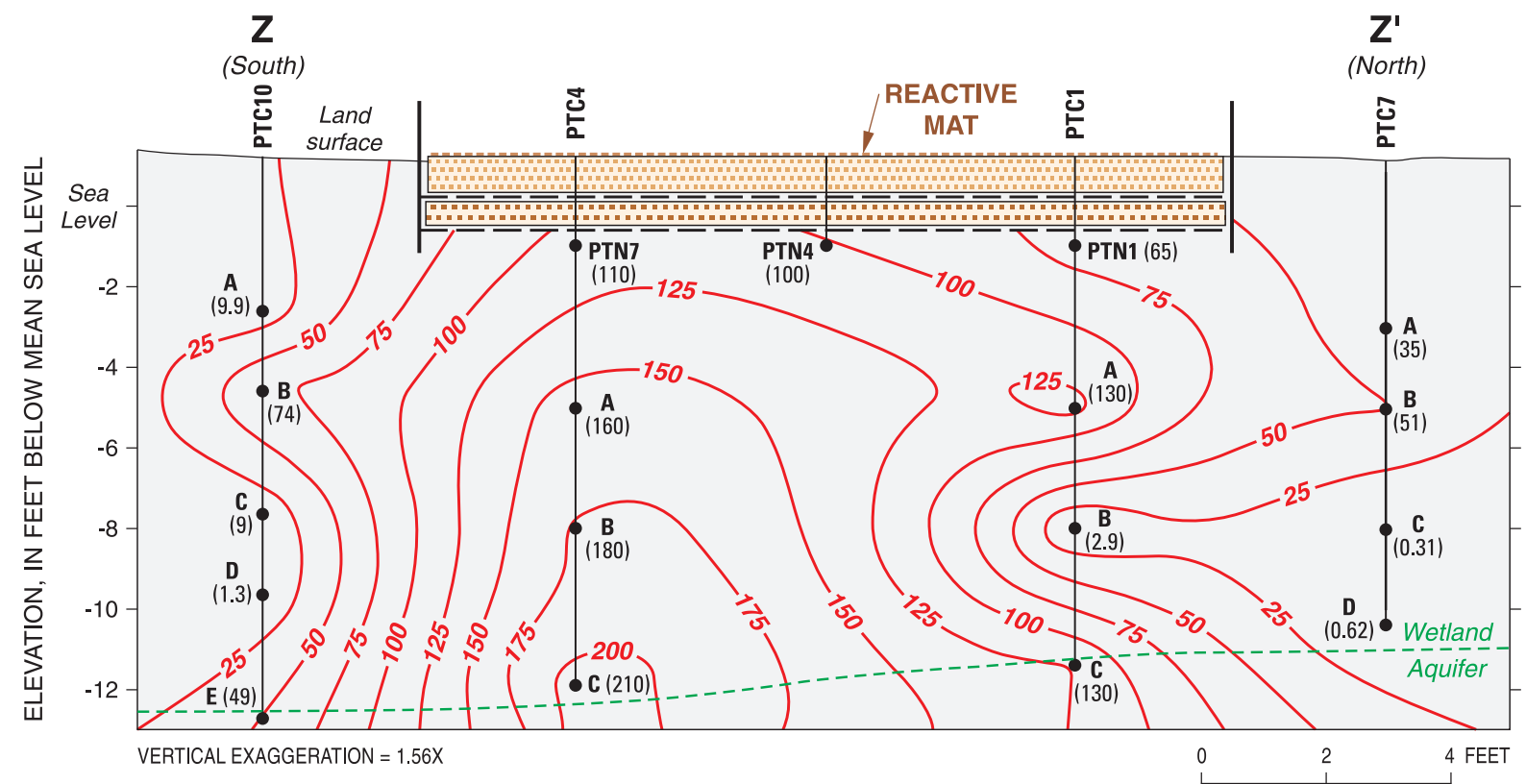

EXPLANATION
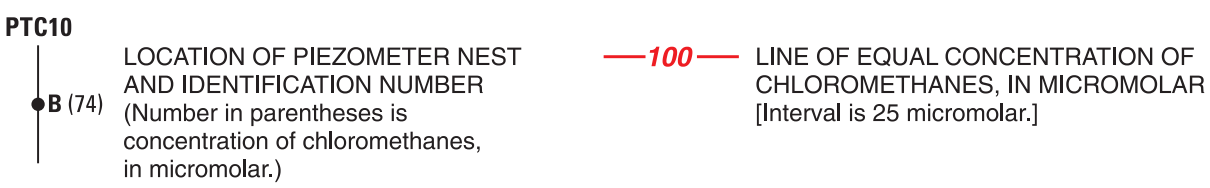

Figure 29. Vertical distribution of chloromethanes along line of section Z-Z', seep 3-4W reactive mat pilot test area, West Branch Canal Creek, Aberdeen Proving Ground, Maryland, August 2005.

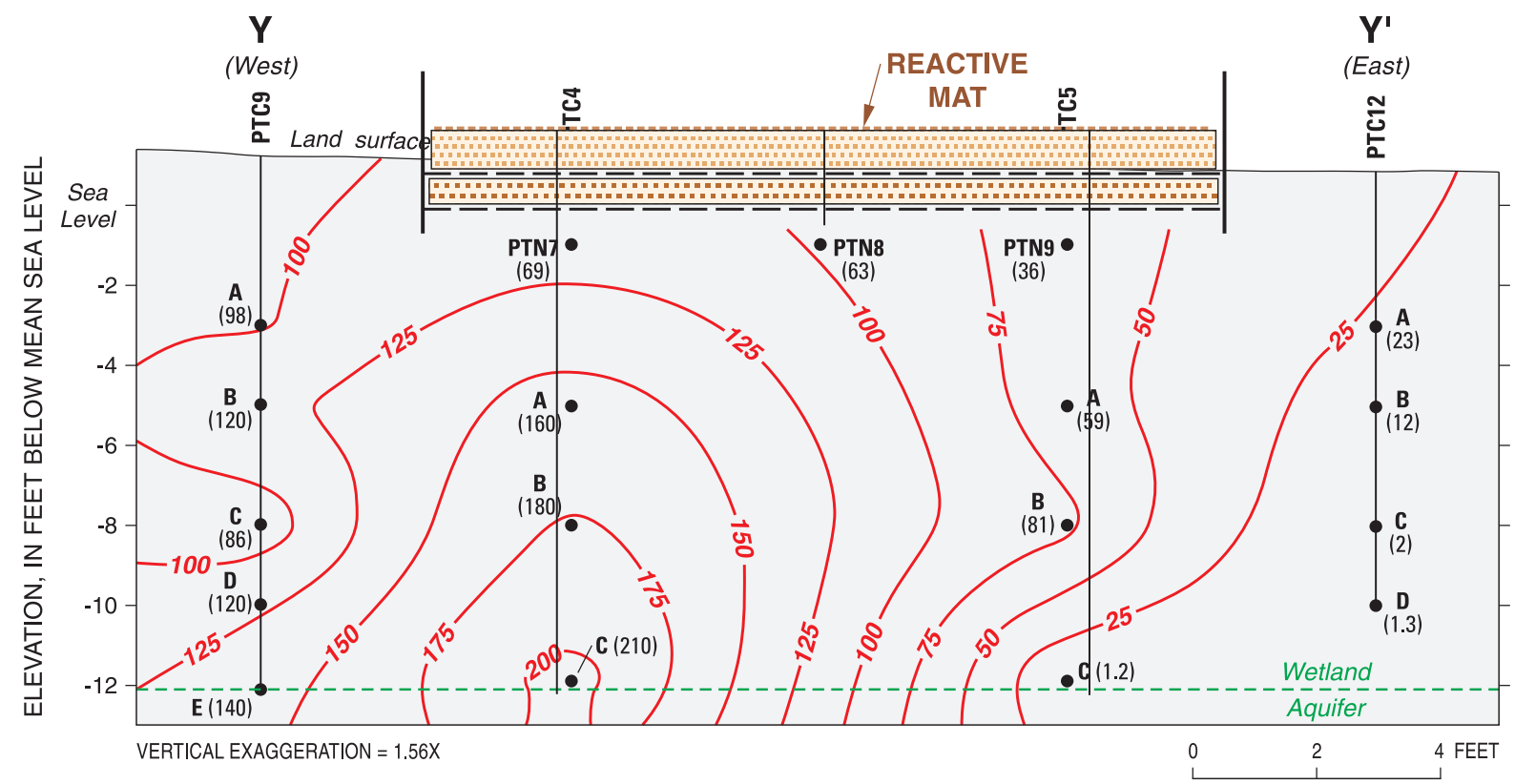

EXPLANATION

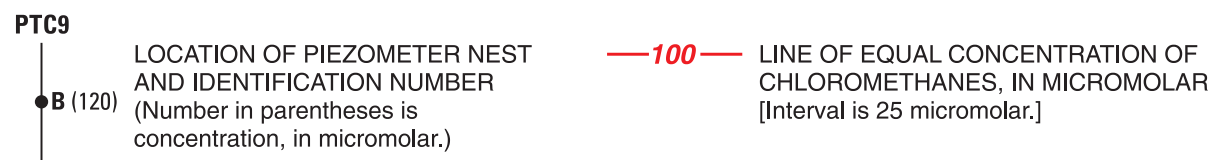

Figure 30. Vertical distribution of chloromethanes along line of section $Y-Y^{\prime}$, seep 3-4W reactive mat pilot test area, West Branch Canal Creek, Aberdeen Proving Ground, Maryland, August 2005. 

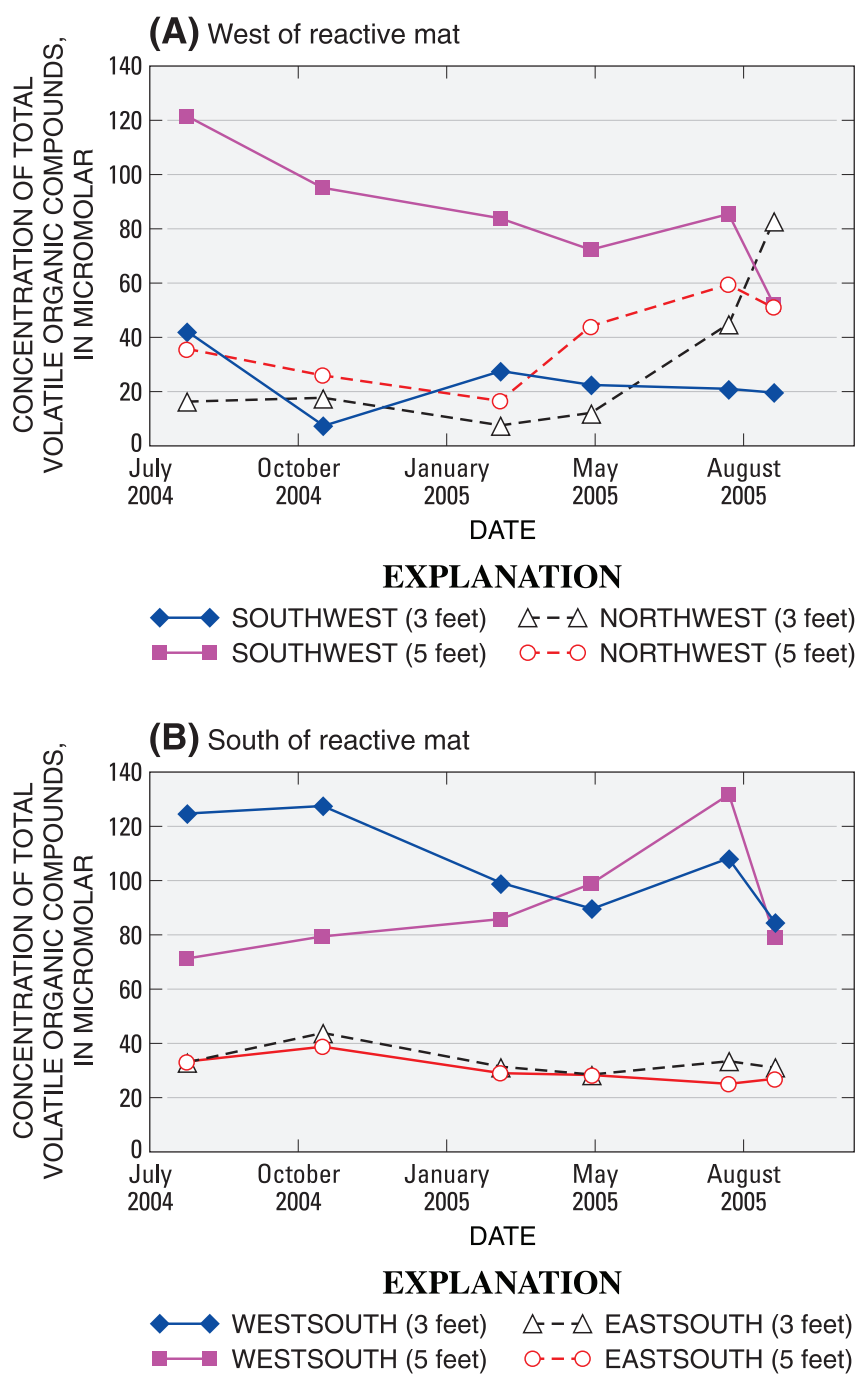

Figure 31. Concentrations of total volatile organic compounds detected in perimeter piezometers, seep $3-4 \mathrm{~W}$ reactive mat pilot test area, West Branch Canal Creek, Aberdeen Proving Ground, Maryland, August 2004-September 2005, (A) west of reactive mat and $(B)$ south of reactive mat.

Monthly surface-water-quality sampling $(\mathrm{pH}$, specific conductance, nutrients, dissolved metals, and VOCs) in the creek channel next to the reactive mat was conducted and results were compared to pre-installation water quality to assess seasonal variations. A slight decrease in $\mathrm{pH}$ was noted after the reactive mat was installed, however, seasonally $\mathrm{pH}$ values were consistent, with median values ranging from 7.6 (August 2004) to 7.0 (February 2005). Similarly, specific conductance was consistent during pre- and post-installation conditions; however, a reduction in specific conductance was observed in December 2004, likely due to the freezing of surface water. Nutrient concentration variability appeared to be highly dependent on season, masking any minimal impact of the mat materials. Ammonia, o-phosphate, and nitrate plus nitrite were consistently higher during winter and spring sampling events compared to summer events, likely due to the growing season in the wetland. During the growing season, wetland plants appeared to utilize excess nutrients in porewater. Baseline conditions were sampled in August 2004, and concentrations appeared to increase following installation and then decreased again during the post-installation summer monitoring events. Nutrients from the reactive mat appeared to be inconsequential in the natural nutrient cycling observed in the creek.

Of the several dissolved metals sampled before and after installation of the mat, seven metals (aluminum, arsenic, copper, iron, selenium, mercury, and silver) were consistently observed before and after deployment and with minor seasonal variation in concentration (Appendix 2). Concentrations of cadmium, lead, cobalt, manganese, and zinc increased in surface water following mat installation. Maximum concentrations of these metals were detected at low tidal stage, indicating that the increase in surface water may be due to increases in base-flow concentrations. Increases in the concentrations of three of these metals corresponded to increases observed in groundwater (lead, manganese, and zinc), despite the lack of change in $\mathrm{pH}$ or redox conditions surrounding the mat. Except for one isolated detection of copper in surface water, concentrations in all samples were substantially lower than USEPA established ambient water-quality criteria (U.S. Environmental Protection Agency, 2006).

Surface-water samples collected along the western part of the creek channel showed little change in total VOC concentrations following deployment of the reactive mat. Comparisons of surface-water concentrations collected monthly following deployment with baseline conditions in August 2004 and previous surface-water investigations (Majcher and others, 2007) indicate a similar range in concentrations before (fig. 33a) and after installation of the mat (figs. 33b,c). Surface-water VOCs were dominated by CF and $\mathrm{CT}$, two of the main parent VOCs found at seep 3-4W. Maximum concentrations were detected during the winter months, when surface-water mixing was inhibited by ice (fig. 33b). Concentrations detected in surface water were affected by tidal stage throughout the monitoring period, with maximum concentrations typically detected during low tidal stage and minimum concentrations detected during times of higher tidal stage (figs. 33b,c).

Overall, results indicated that the installation of the reactive mat had a negligible effect on the quality of groundwater in wetland sediments below and surrounding the reactive mat and on surface water near the pilot test area. Future applications of the reactive mat would benefit from the evaluation of in-mat porewater using dialysis samplers if small volume analysis could be performed. 
(A) $\mathrm{pH}$ in perimeter piezometers

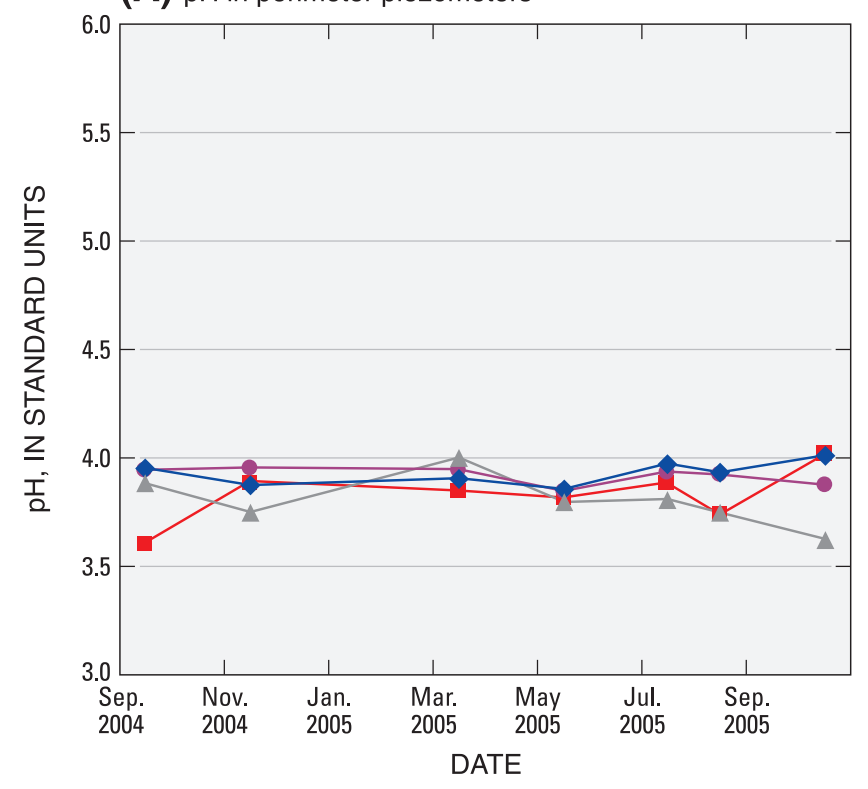

EXPLANATION

$\multimap$ PTC9A $\longleftarrow$ PTC10A $\longrightarrow$ PTC11A $\longrightarrow$ PTC12A

(C) Specific conductance in perimeter piezometers

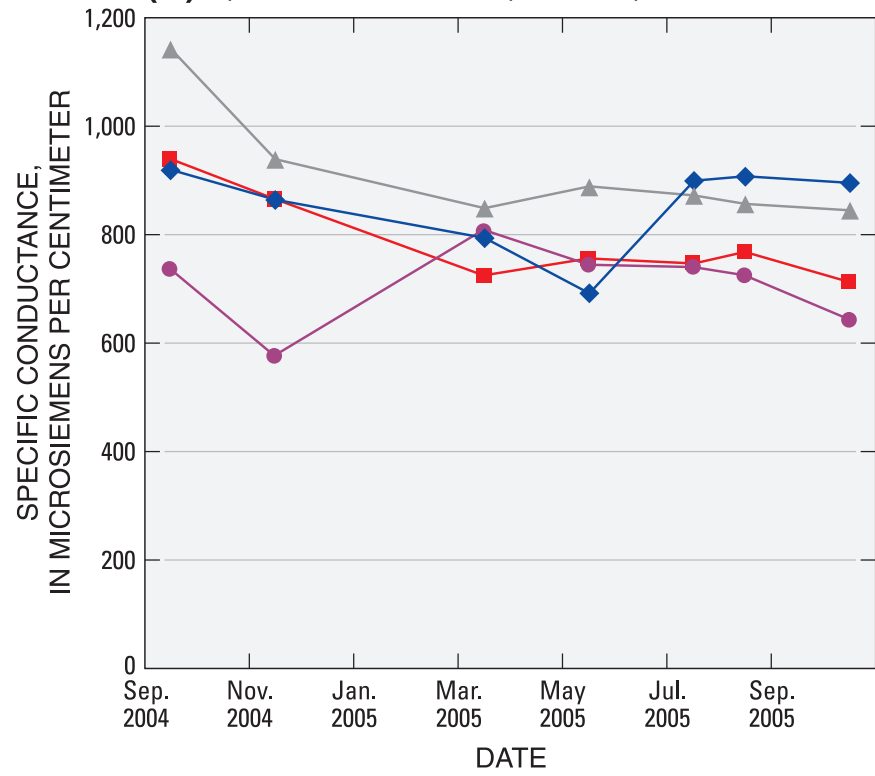

EXPLANATION

$\multimap$ PTC9A $\multimap$ PTC10A $\multimap$ PTC11A $\longrightarrow$ PTC12A
(B) $\mathrm{pH}$ in under-mat samplers

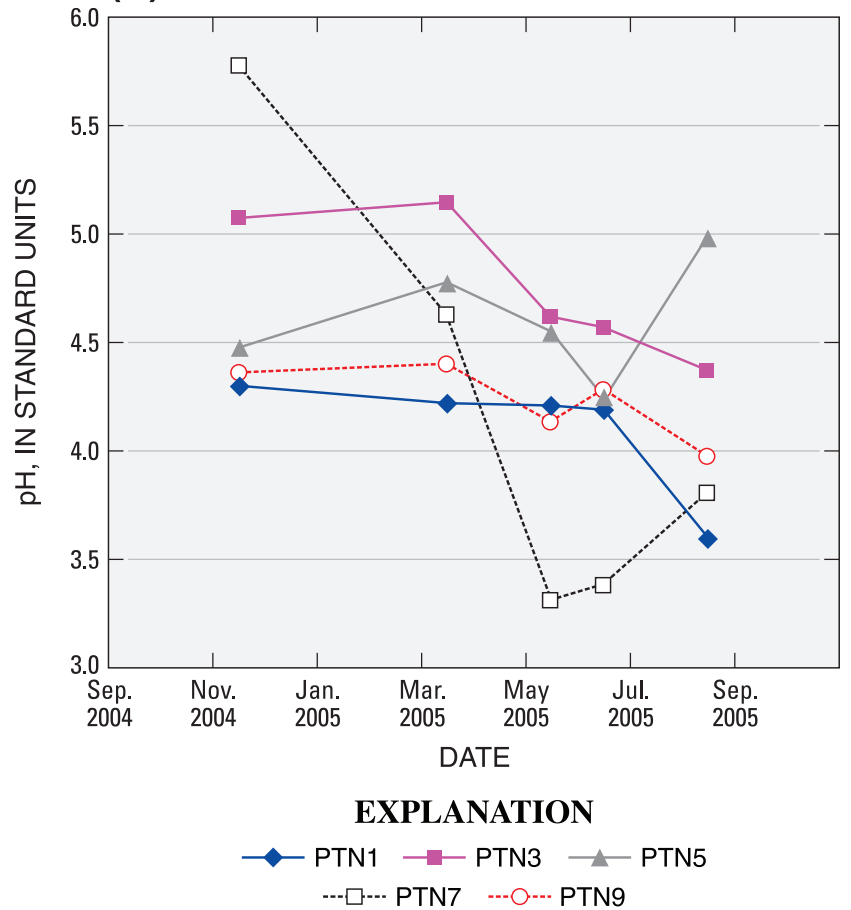

(D) Specific conductance in under-mat samplers

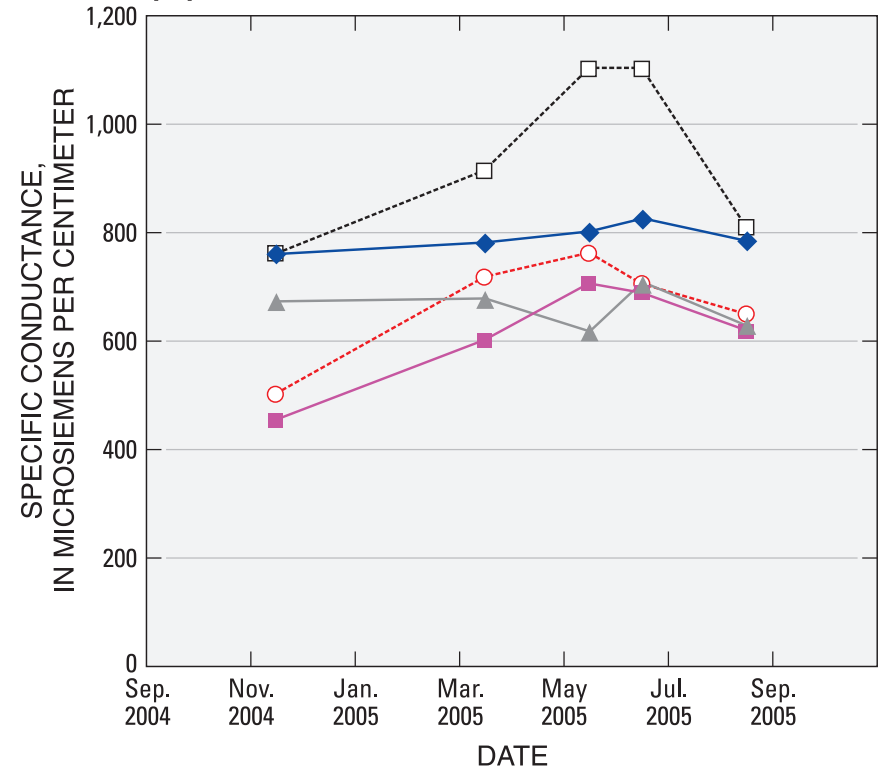

EXPLANATION

$\multimap$ PTN1 —PTN3 $\longrightarrow$ PTN5

--- $\square--$ PTN7 ---O--. PTN9

Figure 32. Quality of wetland sediment porewater, seep 3-4W reactive mat pilot test area, West Branch Canal Creek, Aberdeen Proving Ground, Maryland, September 2004-05, $(A)$ pH in perimeter piezometers, $(B)$ pH in under-mat samplers, $(C)$ specific conductance in perimeter piezometers, and $(D)$ specific conductance in under-mat samplers. 
(A) August 2004

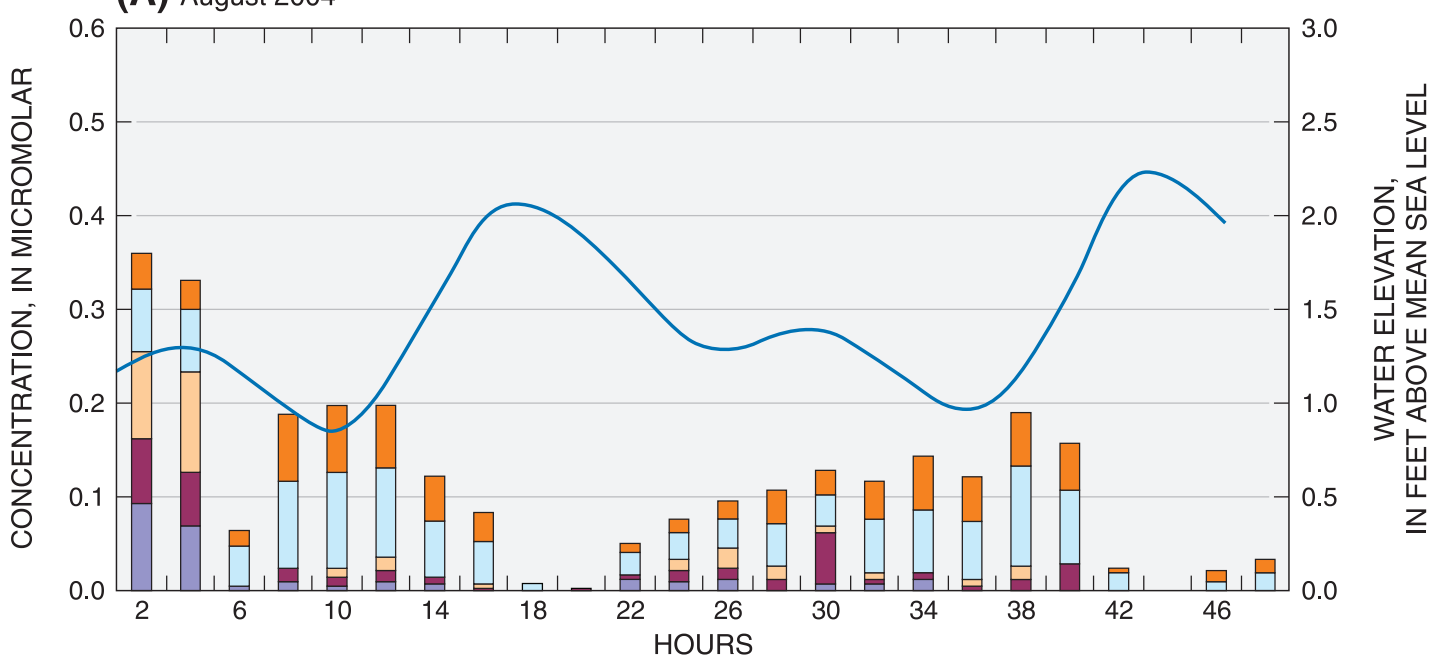

(B) February 2005

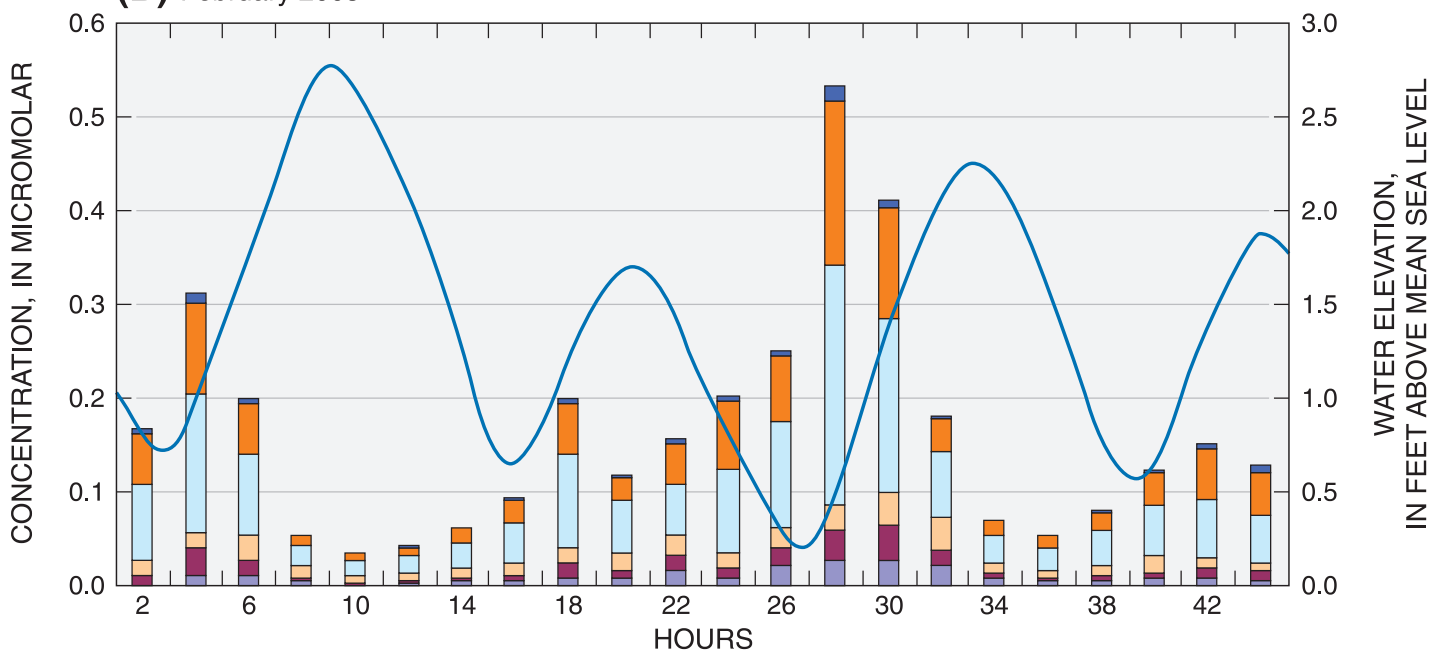

(C) June 2005

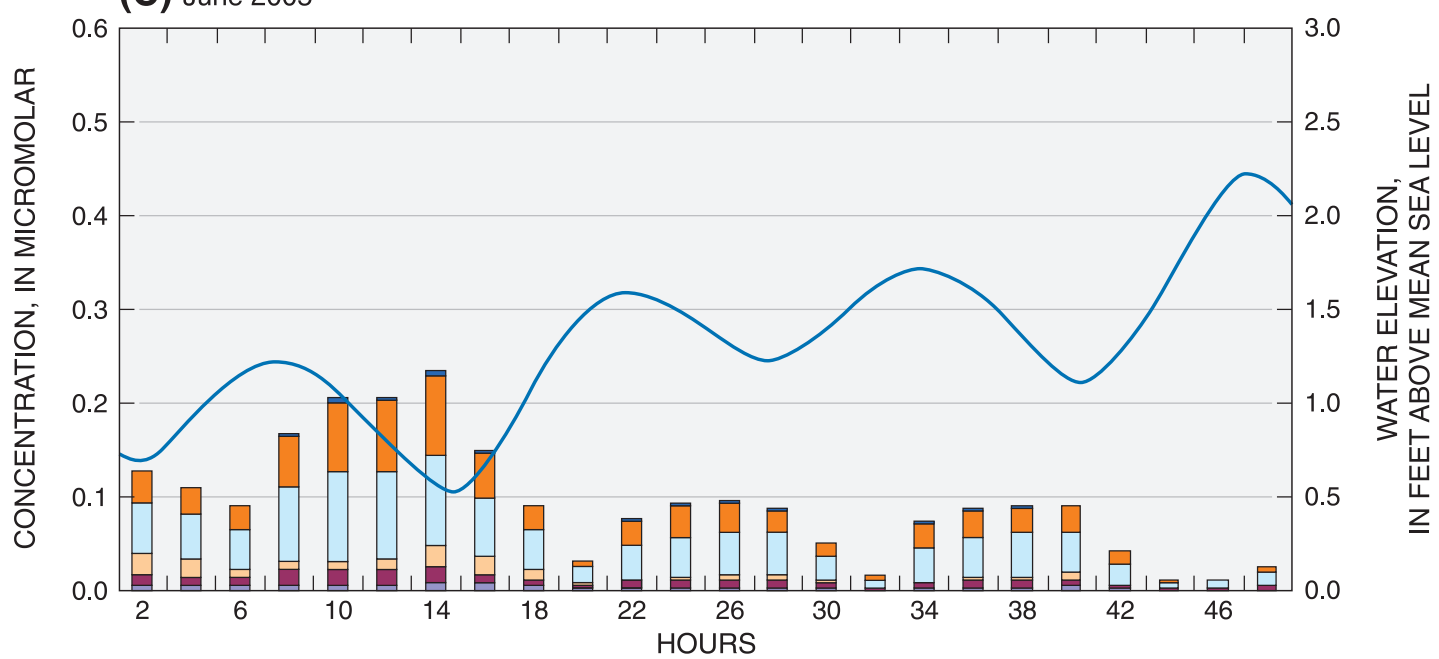

EXPLANATION

$\square$ TCE $\square$ PCE $\square$ TeCA $\square$ CF $\square$ CT $\square$ HCA — WATER ELEVATION

Figure 33. Selected volatile organic compounds in surface water at the seep 3-4W reactive mat pilot test area, West Branch Canal Creek, Aberdeen Proving Ground, Maryland, (A) August 2004, (B) February 2005, and $(C)$ June 2005. 


\section{Summary and Conclusions}

Localized preferential discharge areas (seeps) transport groundwater contaminated with carbon tetrachloride, chloroform, tetrachloroethene, trichloroethene, and 1,1,2,2-tetrachloroethane from the Canal Creek aquifer to land surface of a tidal wetland and stream at West Branch Canal Creek, Aberdeen Proving Ground, Maryland. Due to the lack of in situ remediation methods for sensitive wetland environments and the suite of contaminants found in these seep areas, the U.S. Geological Survey, in cooperation with the U.S. Army Garrison, Aberdeen Proving Ground, Maryland, conceived and designed a permeable reactive mat that was placed horizontally at the seep surface to provide a zone of enhanced degradation for groundwater contaminants flowing upward to the groundwater/surface-water interface. The reactive mat concept was pilot tested at seep area 3-4W along West Branch Canal Creek and monitored from October 2004 through October 2005. The reactive mat consisted primarily of a mixture of commercially available organic- and nutrient-rich peat and compost that was bioaugmented with a dechlorinating microbial consortium, WBC-2, developed for this enhanced bioremediation study. A layer of zero-valent iron (ZVI) mixed with the peat and compost was added to the base of the reactive mat because of the elevated chlorinated methane concentrations in the seep selected for the pilot test.

The reactive mat for seep area $3-4 \mathrm{~W}$ was designed to optimize chlorinated volatile organic compound degradation efficiency without altering the geotechnical and hydraulic characteristics, or creating undesirable water quality, in the surrounding wetland area, which is described in this report as achieving geotechnical, hydraulic, and water-quality compatibility. Optimization of degradation efficiency was achieved through the selection of a sustainable reactive matrix, electron donor, and bioaugmentation method for $\mathrm{WBC}-2$. The reactive mat was comprised of two primary reactive zones-a lower zone designed to enhance abiotic and biotic degradation of chlorinated methanes, and an upper zone designed to enhance biodegradation of the remaining chlorinated methanes, ethanes, and ethenes. The lower zone (termed the ZVI-organic zone) was comprised of ZVI filings combined with an organic matrix that consisted of a mixture of commercially available crab-derived compost, reed sedge peat, and sand. The upper zone (organic zone) was comprised of the compost-peat-sand mixture bioagumented with WBC-2. Chitin was also added to this mixture as a persistent electron donor.

During the design phase, geotechnical compatibility was considered through the evaluation of bearing capacity, settlement, and geotextile selection. Tolerable thickness based on bearing capacity calculations ranged from 2 to 3 feet. Predicted settlement ranged from 0.17 to 1.4 feet for unconsolidated and consolidated sediments, respectively, and was calculated to occur between 1.5 and 6 years following installation of the reactive mat. The sediment and matrix properties indicated that a nonwoven geotextile with a cross-plane flow greater than that of the native sediments was suitable as the base of the reactive mat. At the time of installation, the mat measured 22 inches in thickness above land surface.

Hydraulic compatibility was considered in the design phase by comparing the hydrologic properties of the seep sediments to the expected properties of the reactive matrix and evaluating the potential for fluidization of the reactive mat materials in the artesian conditions at the seep area. Each of the reactive mat materials had a hydraulic conductivity greater than the surrounding wetland sediments, and the mat mixture was optimized to consist of 1.5 parts compost, 1.5 parts peat, and 1 part sand as a safeguard against fluidization. In addition, a nonwoven geotextile was selected for installation between the iron mix zone and the organic zone to create more laminar flow conditions within the mat.

Water-quality compatibility was considered in the design phase by total metals and sequential extraction procedure analysis of native sediments and matrix materials. Results of total metals analysis from three native seep sediment samples revealed that arsenic, lead, mercury, nickel, and zinc concentrations were greater than consensus-based probable effect concentrations for metals in sediment. These metals were bound mostly in the organic, carbonate, non-crystalline, or metal hydroxide fractions, which could be solubilized at low $\mathrm{pH}$ and under the highly reducing conditions that would be generated in the reactive mat. Analysis of the compost used in the pilot test showed concentrations that ranged from one-half to one order of magnitude below consensus-based probable effect concentrations for all metals in sediment.

In October 2004, installation of a reactive mat pilot test was completed at a part of seep area 3-4W along West Branch Canal Creek, and its performance relative to the design objectives was monitored through October 2005. Throughout the monitoring period the mat was assessed for conditions that would facilitate anaerobic degradation (primarly biodegradation) of chlorinated volatile organic compounds. Redoxsensitive constituents (ammonia, iron, sulfide, methane), hydrogen, and WBC-2 activity were assessed to evaluate a change from iron-reducing to methanogenic conditions that are favored by WBC-2. Consistent with results from previous investigations, the amount of methane in samples proved to be the most valuable indicator for appropriate redox conditions. Methane could be used alone (or in combination with iron) in future applications for a more streamlined analytical program to evaluate mat redox conditions.

The immediate dosing of electron donor within the organic matrix (crab compost and chitin) resulted in a rapid establishment in methane concentrations throughout the mat, with relatively high concentrations detected by the first monitoring event in November 2004. Methanogenic conditions were maintained, particularly just above the ZVI-organic zone, throughout the entire monitoring period. A decline in methane concentrations was observed over the winter months at sampling points closest to land surface in the organic zone, as indicated by the decreased concentrations between November 2004 and March 2005. Between May and September 2005, methane concentrations correlated with volatile organic compound concentrations in the reactive mat, particularly at the top of the ZVI-organic zone. 
Results of reactive mat material microbial activity tests indicated that microbial activity, stimulated at least in part by the WBC-2 bioaugmentation within the reactive mat, was sufficient to maintain dechlorinated activity even following the winter months, and that no additional bioaugmentation or biostimulation was required.

Maximum concentrations of volatile organic compounds were typically detected in the spring at all depths. Variation in concentrations within the reactive mat was consistent with volatile organic compound loading from underlying depths and was largely concentrated in the southwest corner of the mat. Maximum concentrations of chloromethanes, chloroethenes, and chloroethanes at all depths during all seasons of the monitoring period occurred primarily in the southwesternwestern area of the mat footprint. Maximum concentrations were detected in monitoring points along the southwest boundary and extended beyond the boundaries of the mat in all directions. Concentration reduction from immediately below the reactive mat to immediately above the ZVI-organic zone was typically at least an order of magnitude. Further removal was frequently observed between the ZVI-organic and organic zones. Variation between the concentrations within the reactive mat was generally small in spite of significant concentration gradients observed at deeper depths within the same area, reflective of substantial mass removal of volatile organic compounds over the narrow mat thickness.

Estimates of mass removal between the base of the mat and the middle of the organic zone were made during the monitoring period to compare to the design goal of 90-percent removal of total volatile organic compounds. The median mass removal of chloromethanes and chloroethenes plus chloroethanes during the entire performance monitoring period was 98 and 94 percent, respectively. The minimum removal in the ZVI-organic level occurred in March 2005. The minimum removal in the upper organic level occurred during May 2005 , corresponding to the increased loading from underlying sediment.

An analysis of individual volatile organic compounds indicated that during baseline conditions and throughout the monitoring period in the southwest corner of the mat, parent compounds carbon tetrachloride, chloroform, tetrachloroethene, trichloroethene, and 1,1,2,2-tetrachloroethane were conserved in the vertical direction through the wetland sediments to a depth of 5 feet below land surface. Following mat installation, transient appearance of primarily trichloroethene, cis-1,2-dichloroethene, vinyl chloride, and methylene chloride was observed in the southwest part of the mat itself. Ethene and ethane were consistently detected in the mat. Overall, these results contrast with pre-installation results, which showed little to no removal of parent volatile organic compounds in the upper sediments.

During the monitoring period, no atypical hydrologic occurrences were observed in the broader West Canal Creek study area. Groundwater discharge remained predominantly vertical following mat installation and during the monitoring period over high and low tides to the north, south, east, and west of the reactive mat. No variation in vertical hydraulic gradients was observed between low and high tide, with mean vertical gradients ranging from 0.20 to 0.26 feet/feet, which is consistent with pre-installation calculations and those reported in an earlier study. Horizontal hydraulic gradients remained at least one to two orders of magnitude lower than those calculated in the vertical direction. The lack of an observable increase in vertical gradient surrounding the mat indicates that its installation did not result in increased hydraulic pressure in nearby wells.

Within the reactive mat itself, the magnitude of hydraulic head difference between porewater and surface water was greater in the mat materials compared to the wetland sediments surrounding the mat at the same tide stage. These measurements indicated a preferential flow through the mat materials along the southeast boundary compared to wetland sediments outside the mat boundary.

Evidence of the more laminar flow conditions was apparent in the aerial thermal infrared flight of the seep area conducted during winter 2005 . The seep area treated with the reactive mat did not appear to be thermally warmer than surrounding sediments as it had in previous flights prior to installation. No new seep areas were apparent in the wetland sediments surrounding the mat either to the west or east of the creek channel; however, previously observed seep areas near 3-4W were consistent with previous flights. Passive sampling of the porewater of these nearby seep areas indicated that transport of volatile organic compounds had not shifted as a result of the reactive mat installation.

No local, immediate failure of the mat or of underlying wetland sediments was observed during mat installation. Measurements of surface elevation of the mat between October 2004 and July 2005 indicated an average settlement of the mat surface of approximately 0.25 feet. This magnitude of settlement was near the range of settlement predicted for the virgin sediment curves (which predicted a range in settlement of 0.12 to 0.37 feet), confirming that the sediments were overconsolidated. Future applications of the reactive mat would benefit from either deeper placement within the native sediments or a thinner mat (if concentrations were lower) to minimize final elevation above land surface.

Results of water-quality sampling for $\mathrm{pH}$, specific conductance, metals, major ions, and nutrients indicated that the installation of the reactive mat had a negligible effect on the quality of groundwater in wetland sediments below and in shallow sediments surrounding the reactive mat and surface water near the pilot test area. Future applications of the reactive mat would benefit from the evaluation of in-mat porewater using dialysis samplers if small volume analysis could be performed.

Overall, the reactive mat showed promise as a lowimpact, high contaminant mass removal approach to remediation of mixed chlorinated volatile organic compounds near the groundwater/surface-water interface. In sensitive environments such as wetlands where existing technologies are not feasible, the reactive mat has been shown to be a positive alternative. During the demonstration, mass removal goals were consistently achieved while compatibility with the surrounding wetland ecosystem was maintained. 


\section{Acknowledgments}

The authors thank the following people and agencies for their contributions to this study. John Wrobel, U.S. Army Environmental Management Division at APG, and Allison O'Brien, Lisa Myers, and Amy Burgess, contractors for the U.S. Army Environmental Management Division are thanked for their support. Heather Hilton, Walter Vuncannon, and the staff of the APG range support program provided logistical support during the planning and installation of the reactive mat. William Kriner of the U.S. Army Corps of Engineers, Baltimore District, loaned the drilling equipment, and William Smithson of the U.S. Army Center for Health and Promotion and Preventive Medicine, Ground Water and Solid Waste Program, Edgewood Area, APG, loaned soil-sampling equipment. James Agiuar and assistant personnel from the Aberdeen Test Center, International Imaging Center assisted with the aerial thermal infrared survey, and Aberdeen Test Center Tech Escort personnel provided unexploded ordnance clearance. Eric Jensen, Paul Botek, Aaron Krasnopoler, Lisa Smith, and Duane Graves from Geosyntec Consultants helped with construction, installation, and performance monitoring of the reactive mat. Sandra Dworatzek, Greg Dreidger, and Jeff Roberts of SiREM Laboratory assisted with maintenance and field application of the WBC-2 consortium. Donna Fennell (Rutgers University), Craig Benson (University of Wisconsin), William Schneider (Weston Solutions), and Jack Lendvay (University of San Francisco) provided technical review and input on the reactive mat design prior to installation. Thanks also are given to colleagues Mastin Mount (USGS, Baltimore, Maryland) and Joseph Beman (USGS, New Mexico) for assistance with field investigation preparation, sample collection, and chemical analyses, Betsy Marchand (USGS, Baltimore, Maryland) for volatile organic compound analyses, Michael Hansen (formerly of USGS, Baltimore, Maryland) for methane analyses, Lisa Olsen (USGS, Sacramento, California) and Tom Imbrigiotta (USGS, West Trenton, New Jersey) for data quality-assurance of volatile organic compound analyses, and Mary Voytek and Elizabeth Jones (USGS Reston, Virginia) for microbial analyses.

\section{References Cited}

Air Force Center for Environmental Excellence, 2004, Principles and practices of enhanced anaerobic bioremediation: Prepared under AFCEE, Contract F4162400-D-8024, August 2004, accessed December 9, 2008 at http://costperformance.org/remediation/pdf/principles_and_ practices_bioremediation.pdf.

American Society for Testing and Materials, 2001, D 2435, Standard test method for one-dimensional consolidation properties of soils, in Annual Book of ASTM Standards: West Conshohocken, PA, ASTM International, p. 237-245.

American Society for Testing and Materials, 2003, D 2850, Standard test method for unconsolidated-undrained triaxial compression test on cohesive soils, in Annual Book of ASTM Standards: West Conshohocken, PA, ASTM International, p. 300-305.

Bagley, D.M., Lalonde, M., Kaseros, V., Stasiuk, K.E., and Sleep, B.E., 2000, Acclimation of anaerobic systems to biodegrade tetrachloroethene in the presence of carbon tetrachloride and chloroform: Water Research, v. 34, no. 1, p. $171-178$.

Beckwith, C.W., and Baird, A.J., 2001, Effect of biogenic gas bubbles on water flow through poorly decomposed peat blanket: Water Resources Research, v. 37, no. 3, p. $551-558$.

Bouwer, E.J., and McCarty, P.L., 1983, Transformation of halogenated organic compounds under denitrification conditions: Applied and Environmental Microbiology, v. 45, no. 4, p. 1,295-1,299.

Brady, W.D., Eick, M.J., Grossl, P.R., and Brady, P.V., 2003, A site-specific approach for the evaluation of natural attenuation at metals-impacted sites: Soil and Sediment Contamination, v. 14 , no. 4 , p. 541-564.

CFR Technical Services, 2005, Treatability study, 1,1,2,2-tetrachloroethane and inoculation procedure, Aberdeen Proving Ground: Edgewood, MD, Produced for General Physics, GP-R-123E05016, March 2003, 48 p.

Clemmer, N.D., 2003, Characterization of chlorinated solvent degradation in a constructed wetland: Wright-Patterson Air Force Base, Ohio, Air Force Institute of Technology (Air University), M.S. Thesis, 146 p.

Coduto, D.P., 1999, Geotechnical engineering: Principles and practices (1st ed.): India, Pearson Education, Inc., 759 p. 
Conant, B.J., Cherry, J.A., and Gillham, R.W., 2004, A PCE groundwater plume discharging to a river: Influence of the streambed and near-river zone on contaminant distributions: Journal of Contaminant Hydrology, v. 73, nos. 1-4, p. 249-279.

Das, B.M., 2002, Principles of geotechnical engineering (7th ed.): Pacific Grove, CA, Brooks/Cole, 589 p.

Ellis, D.E., Lutz, E.J., Odom, J.M., Buchanan, R.J., Jr., Bartlett, C.L., Lee, M.D., Harkness, M.R., and Deweerd, K.A., 2000, Bioaugmentation for accelerated in situ anaerobic bioremediation: Environmental Science and Technology, v. 34, no. 11, p. 2,254-2,260.

Environmental Security Technology Certification Program, 2005, Bioaugmentation for remediation of chlorinated solvents: Technology development, status, and research needs:

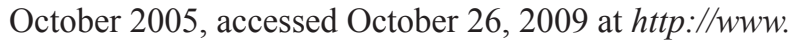
clu-in.org/download/remed/bioaug2005.pdf

Fishman M.J., ed., 1993, Methods of analysis by the U.S. Geological Survey National Water-Quality LaboratoryDetermination of inorganic and organic constituents in water and fluvial sediments: U.S. Geological Survey OpenFile Report 93-125, 217 p.

Fishman, M.J., and Friedman, L.C., 1989, Methods for determination of inorganic substances in water and fluvial sediments: U.S. Geological Survey Techniques of WaterResources Investigations, book 5, chap. A1, 545 p.

General Physics Corporation, 2005, Remedial investigation report, Westwood study area, Aberdeen Proving Ground, Maryland: Edgewood, MD, [variously paged.]

Geosyntec Consultants, Inc., 2004, Interim technical status report: Microbial consortium growth and characterization: Knoxville, TN, Geosyntec Consultants, Inc., Project Number KE0008, 45 p.

Geosyntec Consultants, Inc., 2007, Final technical status report: Microbial consortium growth and characterization: Knoxville, TN, Geosyntec Consultants, Inc., Project Number KE0008, [variously paged.]

Gillham, R.W., and O'Hannesin, S.F., 1994, Enhanced degradation of halogenated aliphatics by zero-valent iron: Ground Water, v. 32, no. 6, p. 958-967.

Haberl, R., Grego, S., Langergraber, G., Kadlec, R.H., Cicalini, A.-R., Dias, S.M., Novais, J.M., Aubert, S., Gerth, A., Thomas, H., and Hebner, A., 2003, Constructed wetlands for the treatment of organic pollutants: Journal of Soils and Sediments, v. 3, no. 2, p. 109-124.

Harvey, J.W., Chambers, R.M., and Hoelscher, J.R., 1995, Preferential flow and segregation of porewater solutes in wetland sediment: Estuaries, v. 18, no. 4, p. 568-578.
Himmelheber, D.W., Pennell, K.D., and Hughes, J.B., 2007, Natural attenuation processes during in situ capping: Environmental Science and Technology, v. 41, no. 15, p. $5,306-5,313$.

Holtz, R.D., and Kovacs, W.D., 1981, Introduction to geotechnical engineering: Prentice Hall, 733 p.

Ingersoll, C.G., MacDonald, D.D., Wang, N., Crane, J.L., Field, L.J., Haverland, P.S., Kemble, N.E., Lindskoog, R.A., Severn, C., and Smorong, D.E., 2000, Prediction of sediment toxicity using consensus-based freshwater sediment quality guidelines: Chicago, IL, U.S. Environmental Protection Agency Great Lakes National Program Office, EPA 905/R-00/007, 33 p., accessed December 9, 2008 at http://www.cerc.usgs.gov/pubs/center/pdfdocs/91126.pdf.

Jones, E.J.J., Voytek, M.A., Lorah, M.M., and Kirshstein, J.D., 2006, Characterization of a microbial consortium capable of rapid and simultaneous dechlorination of 1,1,2,2-tetrachloroethane and ethane and ethene intermediates: Bioremediation Journal, v. 10, no. 4, p. 153-168.

Kassenga, G.R., Pardue, J.H., Blair, S., and Ferraro, T., 2003, Treatment of chlorinated volatile organic compounds in upflow wetland mesocosms: Ecological Engineering, v. 19, no. 5, p. 305-323.

Kassenga, G., Pardue, J.H., Moe, W.M., and Bowman, K.S., 2004, Hydrogen thresholds as indicators of dehalorespiration in constructed treatment wetlands: Environmental Science and Technology, v. 38, no. 4, p. 1,024-1,030.

Koerner, R.M., 1998, Designing with Geosynthetics (4th ed.): Upper Saddle River, NJ, Prentice-Hall, Inc., 761 p.

Lorah, M.M., and Clark, J.S., 1996, Contamination of ground water, surface water, and soil, and evaluation of selected ground-water pumping alternatives in the Canal Creek area of Aberdeen Proving Ground, Maryland: U.S. Geological Survey Open-File Report 95-282, 318 p.

Lorah, M.M., Majcher, E.H., Jones, E.J., Dreidger, G., Dworatzek, S., and Graves, D., 2005a, Electron donor preference of reductive dechlorinating consortium in Alleman, B.C., and Kelley, M.E. eds., In Situ and On-Site Bioremediation-2005, Proceedings of the Eighth International In Situ and On-Site Bioremediation Symposium, Baltimore, Maryland, June 6-9, 2005.

Lorah, M.M., Majcher, E.H., Jones, E.J., Dreidger, G., Dworatzek, S., and Graves, D., 2005b, Physiological characterization of a broad spectrum reductively dechlorinating consortium in Alleman, B.C., and Kelley, M.E. eds., In Situ and On-Site Bioremediation-2005, Proceedings of the Eighth International In Situ and On-Site Bioremediation Symposium, Baltimore, Maryland, June 6-9, 2005. 
Lorah, M.M, Majcher, E.H., Jones, E.J., and Voytek, M.A., 2008, Microbial consortia development, batch microcosms, and column experiments for enhanced bioremediation of chlorinated volatile organic compounds, West Branch Canal Creek wetland area, Aberdeen Proving Ground, Maryland: U.S. Geological Survey Scientific Investigations Report 2007-5165, accessed December 9, 2008 at http://md.water. usgs.gov/publications/sir-2007-5165/index.html.

Lorah, M.M., and Olsen, L.D., 1999, Degradation of 1,1,2,2-tetrachloroethane in a freshwater tidal wetland: Field and laboratory evidence: Environmental Science and Technology, v. 33, no. 2, p. 227-234.

Lorah, M.M., Olsen, L.D., Smith, B.L., Johnson, M.A., and Fleck, W.B., 1997, Natural attenuation of chlorinated volatile organic compounds in a freshwater tidal wetland, Aberdeen Proving Ground, Maryland: U.S. Geological Survey Water-Resources Investigations Report 97-4171, $95 \mathrm{p}$.

Lorah, M.M., Spencer, T.A. and McGinty, A.L., 2005, Temporal changes in indicators of natural attenuation and physical controlling factors for a freshwater tidal wetland contaminated with chlorinated volatile organic compounds, West Branch Canal Creek, Aberdeen Proving Ground, Maryland, 1995-2001: U.S. Geological Survey Scientific Investigations Report 2005-5057, 64 p.

Lorah, M.M., Voytek, M.A., Kirshtein, J.D., and (Phillips) Jones, E.J., 2003, Anaerobic degradation of 1,1,2,2-tetrachloroethane and association with microbial communities in a freshwater tidal wetland, Aberdeen Proving Ground, Maryland: Laboratory experiments and comparisons to field data: U.S. Geological Survey Water-Resources Investigations Report 02-4157, $64 \mathrm{p}$.

MacDonald, D.D., and Ingersoll, C.G., 2002, A guidance manual to support the assessment of contaminated sediment in freshwater ecosystems, Volume III-Interpretation of the results of sediment quality investigations: Chicago, IL, U.S. Environmental Protection Agency Great Lakes National Program Office, EPA-905-B02-001-C, accessed December 9, 2008 at http://www.cerc.usgs.gov/pubs/sedtox/ VolumeIII.pdf.

MacDonald, D.D., Ingersoll, C.G., and Berger, T., 2000, Development and evaluation of consensus-based sediment quality guidelines for freshwater ecosystems: Archives of Environmental Contamination and Toxicology, v. 39, p. 20-31.
Majcher, E.H., Phelan, D.J., Lorah, M.M., and McGinty, A.L., 2007, Characterization of preferential ground-water seepage from a chlorinated hydrocarbon-contaminated aquifer to West Branch Canal Creek, Aberdeen Proving Ground, Maryland, 2002-04: U.S. Geological Survey Scientific Investigations Report 2006-5233, accessed December 9, 2008, at http://pubs.usgs.gov/sir/2006/5233/.

Major, D.W., McMaster, M.L., Cox, E.E., Edwards, E.A., Dworatzek, S.A., Hendrickson, E.R., Starr, M.G., Payne, J.A., and Buonamici, L.W., 2002, Field demonstration of successful bioaugmentation to achieve dechlorination of tetrachloroethene to ethene: Environmental Science and Technology, v. 36, no. 23, p. 5,106-5,116.

Maymó-Gatell, X., Chien, Y.-T., Gossett, J.M., and Zinder, S.H., 1997, Isolation of a bacterium that reductively dechlorinates tetrachloroethene to ethene: Science, v. 276, p. $1,568-1,571$.

Mitsch, W.J., and Gosselink, J.G., 1993, Wetlands: (2d ed.): New York, Van Nostrand Reinhold, 722 p.

Naval Facilities Engineering Command, 1986, Soil mechanics design manual 7.01: Alexandria, VA, Naval Facilities Engineering Command, [variously paged.]

Nemeth, G., 1989, RCRA facility assessment report, Edgwood Area, Aberdeen Proving Ground, Maryland: U.S. Army Environmental Hygiene Agency, Waste Disposal Engineering Division, Aberdeen Proving Ground, Maryland, Project 38-26-0490-90, 929 p.

Novak, P.J., Daniels, L., and Parkin, G.F., 1998, Rapid dechlorination of carbon tetrachloride and chloroform by extracellular agents in cultures of Methanosarcina thermophila: Environmental Science and Technology, v. 32, no. 20, p. 3,132-3,136.

Oliveros, J.P., and Vroblesky, D.A., 1989, Hydrogeology of the Canal Creek area, Aberdeen Proving Ground, Maryland: U.S. Geological Survey Water-Resources Investigations Report 89-4021, $71 \mathrm{p}$.

Olsen, L.D., Lorah, M.M., Marchand, E.H., Smith, B.L., and Johnson, M.A., 1997, Hydrogeologic, water-quality, and sediment-quality data for a freshwater tidal wetland, West Branch Canal Creek, Aberdeen Proving Ground, Maryland, 1992-96: U.S. Geological Survey Open-File Report 97-560, $267 \mathrm{p}$.

O’Niell, W.L., Nzengung, V.A., Noakes, J.E., Bender, J., and Phillips, P.C., 1999, Biosorption and transformation of tetrachloroethylene and trichloroethylene using mixed-species microbial mats: Journal of Hazardous Substance Research, v. 2 , p. $2-1$ to $2-16$. 
Palermo, M., Maynord, S., Miller, J., and Reible, D., 1998, Guidance for in-situ subaqueous capping of contaminated sediments: Chicago, IL, U.S. Environmental Protection Agency Great Lakes National Program Office, EPA 905B96-004, [variously paged.]

Pardue, J.H., 2002, Remediating chlorinated solvents in wetlands: Natural processes or an active approach? in Wetlands and Remediation II, Proceedings of the Second International Conference on Wetlands \& Remediation, September 5-6, 2001: Burlington, Vermont, Battelle Press, Columbus, Ohio, p. 1-8.

Phelan, D.J., Fleck, W.B., Lorah, M.M., and Olsen, L.D., 2002, Changes in ground-water quality in the Canal Creek aquifer between 1995 and 2000-2001, West Branch Canal Creek Area, Aberdeen Proving Ground, Maryland: U.S. Geological Survey Water-Resources Investigations Report 02-4076, $42 \mathrm{p}$.

Phelan, D.J., Olsen, L.D., Senus, M.P., and Spencer, T.A., 2001, Assessment of volatile organic compounds in surface water at Canal Creek, Aberdeen Proving Ground, Maryland, November 1999-September 2000: U.S. Geological Survey Water-Resources Investigations Report 01-292, 49 p.

Phelan, D.J., Senus, M.P., and Olsen, L.D., 2001, Lithologic and ground-water-quality data collected using hoverprobe drilling techniques at the West Branch Canal Creek, Aberdeen Proving Ground, Maryland: U.S. Geological Survey Open-File Report 00-446, 43 p.

Portnoy, J.W., Nowicki, B.L., Roman, C.T., and Urish, D.W., 1998, The discharge of nitrate-contaminated groundwater from developed shoreline to marsh-fringed estuary: Water Resources Research, v. 34, no. 11, p. 3,095-3,104.

Reible, D., Lampert, D., Constant, D., Mutch, R.D., Jr., and Zhu, Y., 2006, Active capping demonstration in the Anacostia River, Washington, D.C.: Remediation Journal, v. 17 , no. 1 , p. $39-53$.

Richard, D.E., Connell, D., Berns, J.J., and Hirl, P.J., 2001, Assessment of a reconstructed wetland for remediation of chlorinated solvents, in Second International Conference on Wetlands \& Remediation, September 5-6, 2001, Burlington, Vermont: Columbus, OH, Battelle Press, p. 117-124.

Schmertmann, J.H., 1953, Estimating the true consolidation behavior of clay from laboratory test results: ASCE Journal of the Soil Mechanics and Foundations Division, v. 79, p. 1-26.

Schultz, M.K., Burnett, W.C., Inn, K.G.W., Thomas, J.W.L., and Lin, Z., 1996, Conference report by the NIST Speciation Workshop: Journal of Research of the National Institute of Standards and Technology, v. 101, no. 5, p. 707-715.
Spencer, T.A., Phelan, D.J., Olsen, L.D., and Lorah, M.M., 2002, Water-quality data for a freshwater tidal wetland, West Branch Canal Creek, Aberdeen Proving Ground, Maryland, November 1999 through May 2000: U.S. Geological Survey Open-File Report 01-420, 302 p.

U.S. Army Corps of Engineers, 1990, Engineering and design: Settlement analysis: 1990, Department of the Army: Army Corps of Engineers: Washington, D.C., Engineering Manual No. 1110-1-1904, accessed October 26, 2009 at http://140.194.76.129/publications/eng-manuals/em1110-11904/entire.pdf

U.S. Environmental Protection Agency, 2002, Biochlor version 2.2, accessed December 9, 2008 at http://www.epa.gov/ ada/csmos/models/biochlor.html.

U.S. Environmental Protection Agency, 2006, National recommended water quality criteria: Office of Water, accessed December 9, 2008 at http://www.epa.gov/waterscience/ criteria/wqctable/.

Vikesland, P.J., Klausen, J., Zimmerman, H., Roberts, A.L., and Ball, W.P., 2003, Longevity of granular iron in groundwater treatment processes: changes in solute transport properties over time: Journal of Contaminant Hydrology, v. 64 , nos. 1 and 2, p. 3-33.

Vroblesky, D.A., 2001, User's guide for polyethylene-based passive diffusion bag samplers to obtain volatile organic compound concentrations in wells, Part 1: Deployment, recovery, data interpretation and quality control and assurance: U.S. Geological Survey Water-Resources Investigations Report 01-4060, 18 p.

Weathers, L.J., and Parkin, G.F., 2000, Toxicity of chloroform biotransformation to methanogenic bacteria: Environmental Science and Technology, v. 34, no. 13, p. 2,764-2,767.

Weathers, L.J., Parkin, G.F., and Alvarez, P.J., 1997, Utilization of cathodic hydrogen as electron donor for chloroform cometabolism by a mixed, methanogenic culture: Environmental Science and Technology, v. 31, no. 3, p. $880-885$.

Weston Solutions (Weston), 2005, Canal Creek Study Area, Remedial investigation report-volume 1, West Canal Creek aquifer and Building E-5188 site, draft, [variously paged.]

Winter, T.C., Harvey, J.W., Franke, O.L., and Alley, W.M. 1998, Ground water and surface water, a single resource: U.S. Geological Survey Circular 1139, 79 p.

Winter, T.C., LaBaugh, J.W., and Rosenberry, D.O., 1988, The design and use of a hydraulic potentiomanometer for direct measurement of differences in hydraulic head between groundwater and surface water: Limnology and Oceanography, v. 33, no. 5, p. 1,209-1,214. 

Prepared by USGS West Trenton Publishing Service Center. Edited by Valerie M. Gaine.

Graphics and layout by Timothy W. Auer.

For additional information, contact:

Director, MD-DE-DC Water Science Center

U.S. Geological Survey

5522 Research Park Drive

Baltimore, MD 21228

or visit our Web site at: http://md.water.usgs.gov 


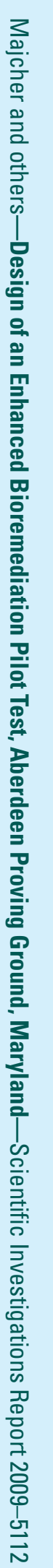

8 Printed on recycled paper 